\author{
UNIVERSIDADE DE SÃo PAULO \\ FACUldade DE Filosofia, LeTRAs E CiênCIAS Humanas \\ DEPARTAMENTO DE ANTROPOLOGIA \\ Programa de PÓS-GRAdUAÇÃo EM ANTROPOLOGIA SOCIAL
}

\title{
A FAMÍlia NAGÔ \\ COMPOSIÇÕES ENTRE O SANGUE E O SANTO NO CANDOMBLÉ DO RECIFE
}

Olavo de SOUZA PinTO FILHO

SÃO PAULO 


\section{Olavo de Souza Pinto Filho}

A Família Nagô. Composições entre o sangue e o santo no candomblé do Recife.

(versão corrigida)

Tese apresentada ao Programa de PósGraduação em Antropologia Social do Departamento de Antropologia da Faculdade de Filosofia, Letras e Ciências Humanas da Universidade de São Paulo, para obtenção do título de Doutor em Antropologia Social, sob orientação do Prof. Dr. Vagner Gonçalves da Silva.

São Paulo 
Autorizo a reprodução e divulgação total ou parcial deste trabalho, por qualquer meio convencional ou eletrônico, para fins de estudo e pesquisa, desde que citada a fonte.

Catalogação na Publicação

Serviço de Biblioteca e Documentação

Faculdade de Filosofia, Letras e Ciências Humanas da Universidade de São Paulo

P659f

Pinto Filho, Olavo Souza

A Família Nagô. Composições entre o sangue e

osanto no candomblé do Recife / Olavo Souza Pinto

Filho; orientador Vagner Gonçalves da Silva - São

Paulo, 2020 .

$272 \mathrm{f}$.

Tese (Doutorado) - Faculdade de Filosofia, Letras e Ciências Humanas da Universidade de São Paulo.

Departamento de Antropologia. Área de concentração: Antropologia Social.

1. Religiões Afro-brasileiras. 2. Candomblé Nagô. 3. Parentesco. 4. Família de santo. I. Silva, Vagner Gonçalves da, orient. II. Título. 
ENTREGA DO EXEMPLAR CORRIGIDO DA DISSERTAÇÃO/TESE TERMO DE CIÊNCIA E

CONCORDÂNCIA DO (A) ORIENTADOR (A)

Nome do (a) aluno (a): OLAVO DE SOUZA PINTO FILHO

Data da defesa: 20/03/2020

Nome do Prof. (a) orientador (a): VAGNER GONÇALVES DA SILVA

Nos termos da legislação vigente, declaro ESTAR CIENTE do conteúdo deste EXEMPLAR CORRIGIDO elaborado em atenção às sugestões dos membros da comissão Julgadora na sessão de defesa do trabalho, manifestando-me plenamente favorável ao seu encaminhamento e publicação no Portal Digital de Teses da USP.

São Paulo, 18/06/2020

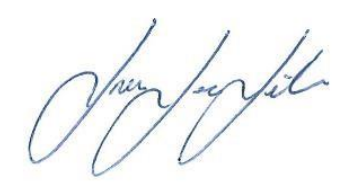

(Assinatura do (a) orientador (a) 
FILHO, Olavo Souza Pinto. A Família Nagô. Composições entre o sangue e o santo no candomblé do Recife. Tese (Doutorado) - Faculdade de Filosofia, Letras e Ciências Humanas. Departamento de Antropologia, Universidade de São Paulo, São Paulo, 2020.

Aprovado em:

Banca Examinadora

José Jorge de Carvalho, Doutor, Universidade de Brasília (PPGAS/UnB)

Marcio Goldman, Doutor, Universidade Federal do Rio de Janeiro (PPGAS/MN)

Renato Sztutman, Doutor, Universidade de São Paulo (PPGAS/USP)

Rosenilton Silva de Oliveira, Doutor, Universidade de São Paulo (PPGE/USP) 
À memória de Paulo Braz Felipe da Costa, Baba Ifamuide. 


\section{Agradecimentos}

Meu profundo agradecimento à família Felipe da Costa. Minha vida foi outra a partir do nosso encontro, a intensidade de minha gratidão é expressa pelo amor que sinto. Em especial, ao Baba Paulo Braz (in memoriam), pela amizade, confiança e generosidade. Foi uma grande honra ter compartilhado de seu dia a dia nos últimos anos de sua vida. Agradeço à Mãe Lu, por ter me acolhido em sua casa desde o primeiro dia, e pelo o carinho diário. O que mais me honra em nossa relação é ser chamado pela senhora como filho. Por ser minha mãe em Recife, pela generosidade do tamanho do oceano, a Iemanjá mais linda que existe, esta pesquisa só foi possível por sua vontade e dedicação.

A Junior Boto, obrigado pelas trocas e fraternidade. Agradeço pela confiança e amizade, e o exemplo no cuidado e dedicação aos orixás.

A Paulinho, sou grato pela convivência no dia a dia, pelos conselhos, cervejas e risadas que compartilhamos. Acima de tudo, agradeço o sentimento mútuo de fraternidade.

Agradeço a Marcio por me apresentar, e respeitar, os Maracatus do Recife. Obrigado pela amizade e confidência.

Agradeço a Bino por ter me ensinado tanto sobre o bairro de Água Fria e sobre os terreiros. Por ter sido um amigo desde o primeiro momento de minha chegada. Obrigado por ter me apresentado a tantas pessoas e casas de santo, e pela confiança nos convites para as obrigações.

Meu muito obrigado a Barbara e seus filhos, Thauany, Thalysson e Thalita.

Obrigado ao meu irmão Idelfonso e toda sua família, pela generosidade em sempre me receber em sua casa, por compartilhar tanto conhecimento sobre a história do nagô, do Sítio e de sua família. Obrigado pelos almoços e feliz embriaguez de nossos encontros.

Agradeço a Pai Guara e Marcelo, pelo exemplo de dedicação, amor e devoção aos orixás. Obrigado pela profunda generosidade em me receberem em sua casa.

Obrigado Alexandre L'Omi L'Odo, jovem mestre da vida pernambucana, à Thandra, Alisson, Dão, Vandinho, Tio Cinho, Cianinha, Roberto, Lucas do Sítio, Pelado, Pelezinho, Tiago Nagô, Tia Nina, Maycon, Ronny, André de Oxalá, Pedro Germano, Tia Edna e irmãs. Obrigado a esses e tantos outros com quem convivi e tive o imenso prazer de compartilhar da vida nesses anos.

Sou grato por ter cursado, em toda a minha vida, o ensino público brasileiro, que hoje se encontra diante de um profundo ataque. Sou grato à CAPES pelas bolsas de mestrado e doutorado que permitiram este estudo. 
Meu grande agradecimento e dívida para com os professores que aceitaram participar dessa banca. Em primeiro lugar, agradeço a Renato Sztutman, pelas excelentes aulas e trabalho inspirador, por ter aceitado ler e contribuir com um trabalho de outra etnologia. Muito obrigado.

A Marcio Goldman, cujo trabalho e pensamento admiro profundamente. Sou grato pela generosidade em compartilhar seu conhecimento e ideias, pela amizade e incentivo para o desenvolvimento deste trabalho. Obrigado por ter me acolhido em suas aulas no Rio de Janeiro e especialmente pelas saudosas sextas-feiras.

Por fim, expresso minha profunda gratidão e admiração a José Jorge de Carvalho. Agradeço a generosidade de ter me feito conhecer e amar as incríveis pessoas do nagô; pelo encontro na luta antirracista e na transformação da universidade; pelas aulas (dentro e fora de sala), que sempre foram um grande ambiente de compartilhamento e discussão com os alunos, nos ensinando a pensar e agir de outras formas.

Em Recife, devo ainda a gratidão das amizades feitas para a vida: Fabinho, Claudia, Breno; à Família Amoras e à Família Silva. Minha gratidão.

Em Brasília, cidade que abriu caminhos para uma outra vida e onde tive a mais plena vida universitária, com os melhores anos de Governo Lula e seus investimentos na educação pública, agradeço aos amigos: Danilo, Paique, Fernanda, Ranna, Guilherme, Mariana, Lety e Fabi, Ceariba, Farage, Gregório, Zé do Boné, Chico, Herikinha, JM, Paulete, Ester, Aline Dandara, Rafa Pai, Rods, Joao Lucas, Humberto, Flora e família. Ainda em Brasília, agradeço aos professores que inspiraram na antropologia. Em especial, agradeço a Marcela Coelho Stockler pelas aulas, conversas, amizade e por ter contribuído para este trabalho quando participou da banca de qualificação.

Na USP, agradeço especialmente meu orientador Vagner Gonçalves da Silva, por ter aceitado me orientar logo no mestrado, em minha mudança para São Paulo, e por sempre ter acreditado nos projetos. Obrigado pelo apoio, incentivo, disposição, confiança e paciência. Sou grato ainda pelas leituras atentas e comentários incentivadores que sempre fez.

Aos professores do PPGAS, agradeço a Ana Claudia Marques, pelos excelentes cursos ofertados, pelo posicionamento político e pensamento crítico e desafiador. Sou grato a Marina Vanzolini por ter aceitado o convite de compor a banca da tese e pelos trabalhos pelos quais tenho grande admiração.

Aos colegas do Cerne, em especial Rosenilton, que também aceitou compor a banca e sempre deu excelentes contribuições; a Patrícia, Paula e Bruna; e a minha aburé Yumesita. Muito obrigado.

Devo agradecer a convivência com meus amigos e amigas, mais do que especiais, da minha turma de mestrado. Compartilhei da alegria, irreverência e amizade de vocês: Helena, Álvaro, Bruno, Augusto, Yara, Camila, Renan, Vitão e Lauriene, 
No Rio de Janeiro, agradeço aos colegas que fiz no PPGAS do Museu Nacional. Em especial, ao Nansi, que me proporcionou tantas reflexões e inspirações. Obrigado, Clara, Gabriel Banaggia, Suzana, Luisa Elvira, Gustavinho, e tantos outros. Sou grato à família criada em terras cariocas, Helena, Bárbara, Cris, Maria.

A meu Baba Toloji e à comunidade Ogun lakaye Osinmole, pelo axé que me levou por esses caminhos ao longo dos anos.

À minha família: Meu pai, Marcio, sem seu amor e suporte eu não teria trilhado este caminho. Minha mãe, Rosângela, pelo amor e incentivo desde os primeiros anos e por ter sido sempre meu maior exemplo. Minha irmã, Angélica, e meu irmão, João, pelo amor incondicional. E meus sobrinhos, Dudu e Rafinha.

Esta tese se deve muito a meu grande amigo e parceiro Lucas Marques, pela leitura, sugestões e, acima de tudo, amizade. À Barbara, pela amizade, carinho e disposição em ler, revisar e comentar esta tese, durante esses anos. À Noshua Amoras, pelo amor e companheirismo, e, acima de tudo, lutas! 


\section{Resumo}

SOUZA PINTO, Olavo Filho. A Família Nagô. Composições entre o sangue e o santo no candomblé do Recife. Tese (Doutorado) - Faculdade de Filosofia, Letras e Ciências Humanas. Departamento de Antropologia, Universidade de São Paulo, São Paulo, 2020.

Esta tese tem como tema central a composição do parentesco na casa de candomblé nagô Ilê Iemanjá Ogunté, em Recife, Pernambuco. Essa família configura-se como uma extensa rede de casas, pessoas, divindades e antepassados relacionados a partir de duas linhas, criadas a partir do ritual, a do sangue e a do santo. Meu ponto de partida é a distinção (e não oposição) estabelecida pelos integrantes do terreiro desse aspecto fundamental da família, uma disposição que se replica, em diferentes escalas, em demais dimensões da vida do nagô. O principal objetivo da pesquisa é descrever certas composições expressas por meio do parentesco, tais como iniciação, transmissão de nomes, objetos rituais, assentamentos, capacidades intuitivas e criatividade, que conformam heranças espirituais nas quais o sangue e santo surgem como linhas coextensivas dispostas pela ação ritual.

Palavras-chave: família de santo; parentesco; candomblé nagô; religiões afro-brasileiras. 


\section{Abstract}

SOUZA PINTO, Olavo Filho. The Nagô Family. Compositions between blood and saints in the candomblé of Recife. Tese (Doutorado) - Faculdade de Filosofia, Letras e Ciências Humanas. Departamento de Antropologia, Universidade de São Paulo, São Paulo, 2020.

This thesis has as its central theme the composition of kinship in the Nagô Candomblé house Ilê Iemanjá Ogunté, in Recife, Pernambuco. This family is configured as an extensive network of houses, people, deities and ancestors related by two lines, one of blood and the other of saint. My starting point is the distinction (and not opposition) established by the members of the terreiro about this fundamental aspect of the family, a disposition replicated, in different scales, in other dimensions of nagô's life. The main objective of the research is to describe certain compositions expressed through kinship, such as initiation, name transmission, ritual objects, assentamentos, intuitive capacities and creativity, which all form spiritual inheritances in which blood and saint appear both as coextensive lines arranged by ritual action.

Keywords: saint family; kinship; candomblé nagô; afro-brazilian religions 


\section{SUMÁRIO}

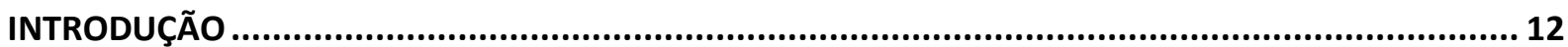

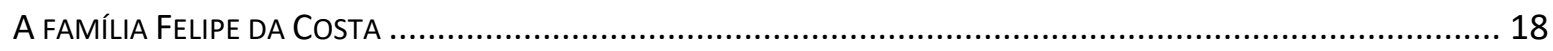

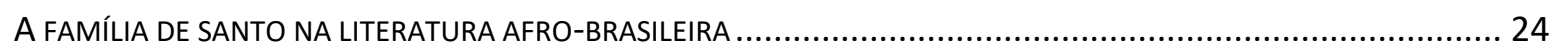

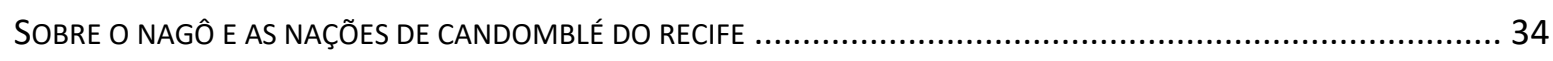

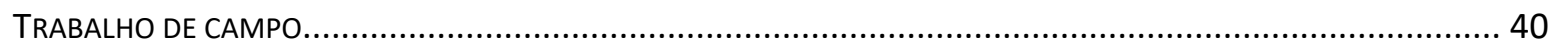

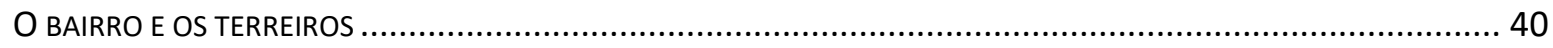

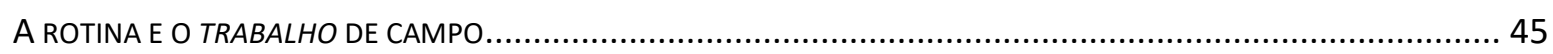

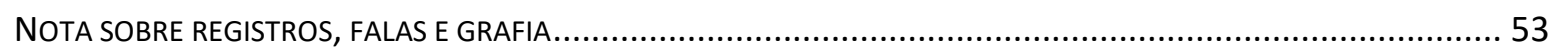

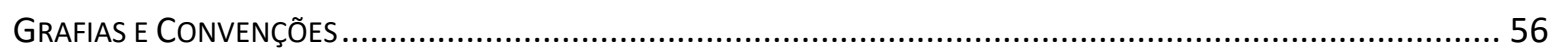

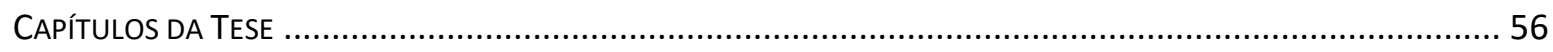

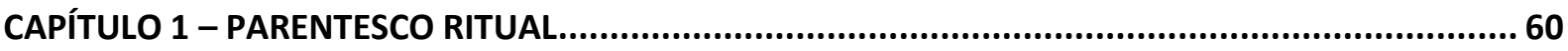

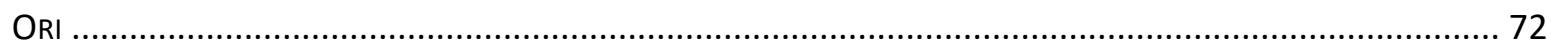

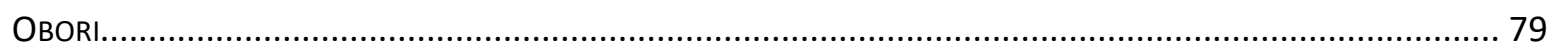

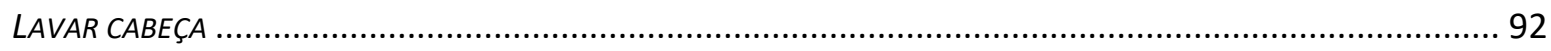

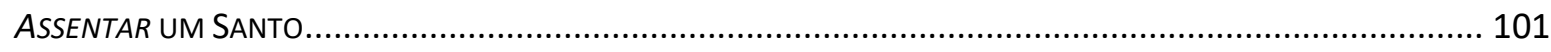

SAÍDA DE IYAWO

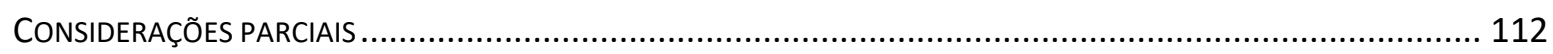

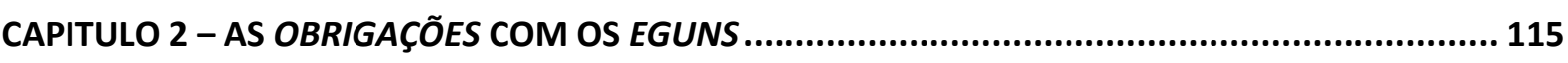

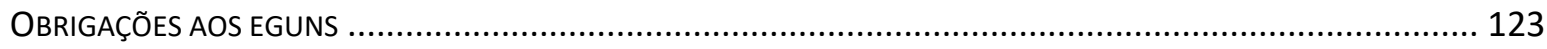

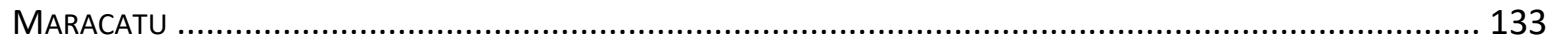

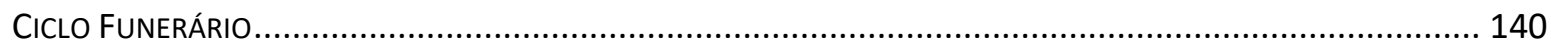

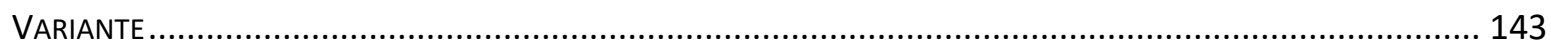

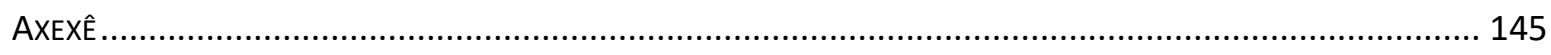

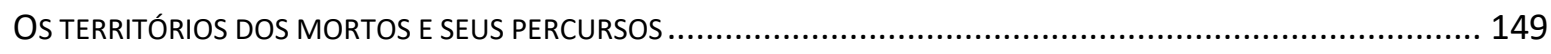

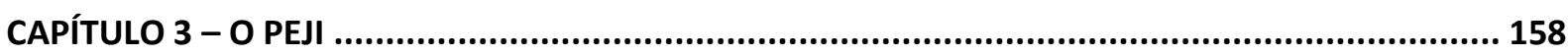

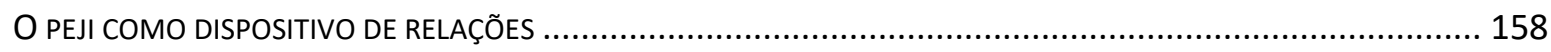

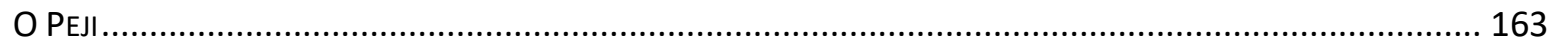

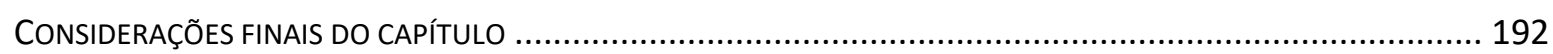

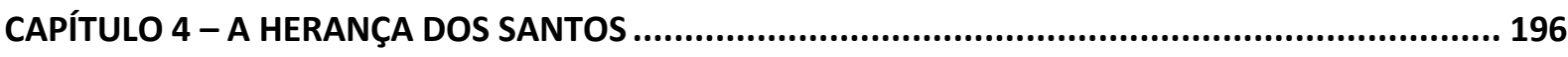

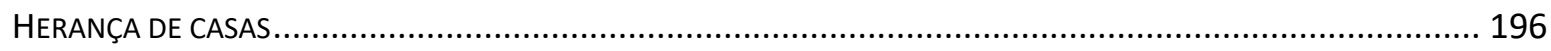

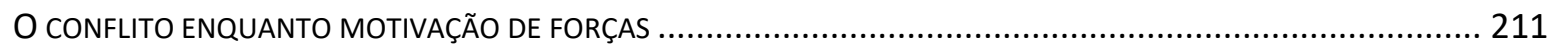

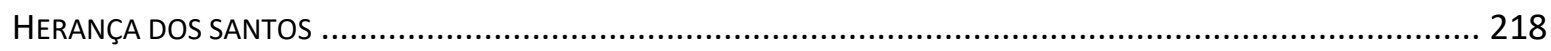

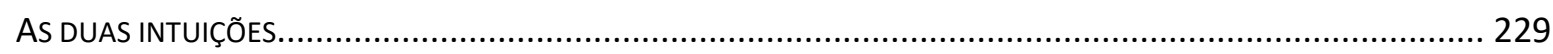

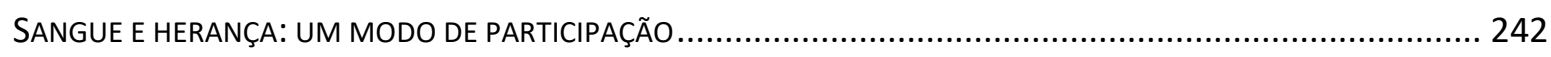

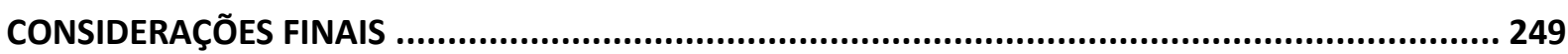

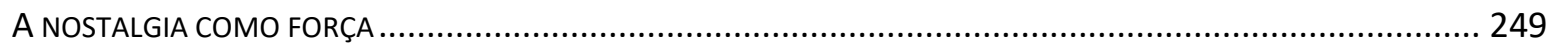

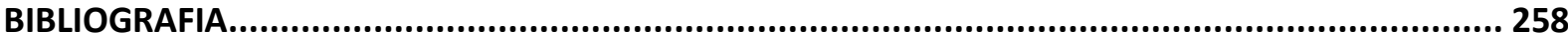

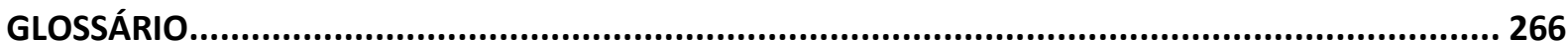




\section{INTRODUÇÃ̃O}

Conheci Pai Paulo em dezembro de 2012, seguindo uma recomendação do meu orientador da graduação, José Jorge de Carvalho. Na época, havia finalizado minha monografia sobre Ifá ${ }^{1}$, em Brasília, e, posteriormente à defesa da monografia, Jorge me disse: "Você precisa ir para Recife e conhecer Paulo, que está reescrevendo os versos de Ifá". No final daquele ano, em um cair da noite, cheguei à casa da família Felipe da Costa, na Rua Abdon Lima, 86, no bairro de Água Fria. O portão estava aberto, encontrei Pai Paulo sentado na poltrona marrom. Pai Paulo era um homem negro, de setenta e poucos anos, e estatura forte. Muito comunicativo, era um excelente cantor, além de exímio tocador de ilu (tambor de madeira com peles de cabrito em suas duas extremidades). Ele podia passar horas contando histórias sobre sua juventude ou sobre seus ancestrais. Era considerado, entre os terreiros da região, um dos maiores conhecedores do nagô, e extremamente zeloso dos feitos de seus antepassados. Às vezes, quando se empolgava ao cantar uma toad $a^{2}$, levantava-se dançando em um estilo característico - o que causava grande alegria por parte dos que lhe assistiam. "Danço como meu pai", ele dizia, invariavelmente, com um sorriso no rosto.

Na minha chegada ao Recife, no final de 2016, fui surpreendido com uma mensagem da sobrinha de Pai Paulo, dizendo que ele estava doente e que estavam todos preocupados. No outro dia, pela manhã, me dirigi ao terreiro e encontrei Pai Paulo deitado, assistindo TV. Mãe Lu pergunta se ele sabia quem chegou, ele me reconhece. Peço a sua benção e começamos a conversar. Ele falava com alguma dificuldade e permaneceu deitado todo o tempo. Conversamos sobre a festa de Iemanjá ocorrida dias antes; ele me contou sobre seu obori $^{3}$. E, como de costume, lembrou-se dos tempos antigos de sua família e de como seu pai e seu tio cantavam e dançavam. Mãe Lu me chama para a cozinha e diz estar muito preocupada com seu irmão, e que achava que ele tinha tido outro acidente vascular cerebral (AVC). "Ele me confundiu com minha mãe, me chamou de mãe”, disse ela. Na noite anterior, notou que ele

\footnotetext{
${ }^{1}$ Ifá, um sistema oracular de origem africana, que é baseado no manejo de dezesseis nozes de dendê ou búzios, para obter uma combinação entre um conjunto de 256 signos gráficos denominados odus. Ifá, dizem os Babalaôs ("pais dos segredos"), é o jogo " $d a$ fa", por onde fala Orumila. Segundo ouvi de um importante sacerdote de Ifá: "Ifá significa palavra forte na boca de Orumilá. Ifá explica tudo, não existe nada no mundo e na vida que não tenha explicação em Ifá”. Para alguns em Recife, Ifá e Orumilá são o mesmo ser, não sendo possível diferenciálos. Outros afirmam que Ifá é o jogo criado por Orumilá e, portanto, Orumilá não seria exatamente a personificação de Ifá, mas seu inventor. Segundo Pai Paulo, Ifá seria Odifá, "por onde fala Orumilá".

${ }^{2}$ Músicas para os orixás.

${ }^{3}$ Obrigação para a "cabeça", com vistas a fortificar o corpo e o espírito. Sobre isso, conferir capítulo 1 da tese.
} 
estava com muita dificuldade de sair da cama. Falou ainda que o recado do jogo de búzios não viera bom e por isso tinha feito um ebó dinan ${ }^{4}$, e que, nessa ocasião, mesmo com dificuldades, pai Paulo havia cantado o repertório de cânticos destinados a Orixalá. Combino, então, de acompanhar Pai Paulo ao médico.

No dia seguinte, após muitas tentativas, conseguimos um atendimento para Pai Paulo em uma Unidade de Pronto Atendimento (UPA), próxima ao terreiro. Ao chegarmos, a médica que o atendeu disse que ele estava debilitado e confuso em decorrência de uma interação medicamentosa, mas que não identificara qualquer sintoma de AVC. Pai Paulo é liberado e segue para João Pessoa, cidade em que residia. Dois dias depois, ele é internado às pressas: seu caso se agravara e fora diagnosticado, após uma ressonância, um coágulo em seu cérebro. Ele ficou internado por, aproximadamente, 10 dias na UTI. Na noite de sua morte, Mãe Lu se preparava, juntamente com sua irmã, para visitá-lo - ele seria transferido para um quarto, no qual poderia receber visitas de parentes e amigos. "Ele pediu que eu vá para rezar um salmo para ele”, disse Mãe Lu. O pedido de Pai Paulo havia sido transmitido por um amigo da família, um dos poucos autorizados a visitá-lo. Nesse dia, ele contou à Mãe Lu que Pai Paulo estava bem melhor, pedira auxílio para fazer sua barba e cantara muitas músicas da Jurema da família: “Ele é um Reis, ele é um Reis que em Vajucá chegou. Bonito é os saberes que Vajucá deixou”. A melhora clínica de seu quadro foi saudada com muito entusiasmo. Combinei de ir a João Pessoa quando ele pudesse receber visitas. Depois de ouvir as atualizações de seu quadro, retorno para casa. Aproximadamente duas horas depois, minha companheira me acorda com a terrível notícia de sua morte. Pai Paulo faleceu pouco depois da partida de suas irmãs, elas não conseguiram alcançá-lo com vida. O pedido da reza já era uma despedida. Ele foi meu principal mestre no universo nagô e um grande amigo.

Paulo Braz Felipe da Costa era neto do famoso babalorixá recifense Felippe Sabino da Costa, mais conhecido como Pai Adão. Era filho de Malaquias Felipe da Costa com Leônidas Josefa Felipe da Costa. Pai Paulo faleceu no dia 27 de dezembro de 2016, em decorrência de um AVC. Era possuidor de uma biografia destacada e valorizada por todos os seus familiares. Nascido e criado em meio a muitas dificuldades econômicas e sociais que ainda afetam as famílias negras no Brasil, num contexto em que o racismo é cotidiano e violento, ele conseguiu sobrepor essa situação e seguiu a profissão de bancário, chegando a ocupar o posto de gerente regional de um banco de grande porte, conseguindo se aposentar com uma renda que lhe garantia relativo conforto se comparado à situação inicial de sua família. A despeito de sua

\footnotetext{
${ }^{4}$ Uma oferenda destinada a resolver casos graves de doença ou aflição feita para o orixá Orixalá..
} 
relativa ascensão financeira, Pai Paulo não deixou de ser vítima do racismo, especialmente, o racismo médico. Seus filhos seguem seus passos e se consolidam como importantes personalidades no universo do candomblé nagô, e suas filhas chegaram à pós-graduação, progredindo em um ambiente de forte segregação racial, os corredores universitários brasileiros. Sobre isso, Pai Paulo sempre dizia: "Sinto muito orgulho em dar condições delas estudarem e não precisarem ser empregadas domésticas de nenhum branco, porque é muito sofrido".

Em 1997, Pai Paulo teve um infarto seguido de um AVC. Seu médico lhe disse que, para ajudar em sua recuperação, era preciso ler e fazer anotações em voz alta. Um amigo, então, lhe deu um livro sobre Ifá, no qual ele lia os odus (configurações do jogo), anotando-os em um caderno. Segundo ele, “essas coisas eu já sabia, eu já tinha isso, mas quando eu li o livro, essas coisas se encaixaram, foi com isso que me curei”. Essa cura, por intermédio do aprendizado do jogo de Ifá, deu-lhe um novo nome, "Ifatóògún”, que significa: Ifá é meu remédio, "fui curado por Ifá".

A experiência foi motivada por esse evento dramático na vida de Pai Paulo. Foi a doença que motivou um processo de cura por meio da leitura. Essa leitura, por sua vez, foi o que motivou sua recuperação do jogo de Ifá, jogo que tinha desaparecido do Recife no início do século passado. Porém, isso não foi tudo. Para empreender essa atualização, Pai Paulo precisou "reconstruir" o sistema de Ifá por meio da composição dos versos contidos no odu que o livro não retratava. Entretanto, "reconstruir" não seria o termo mais preciso para descrever essa atualização. "Recuperar" o jogo de Ifá é a maneira mais apropriada de descrever essa experiência, uma vez que esse jogo já esteve presente na história de sua família, de certo modo, com uma participação latente.

A atualização do jogo de Ifá por Pai Paulo, na forma dos versos que ele elaborou, apresenta modos de criação que não passam por uma criação ex nihilo. Essa atualização dispõe e expressa diferentes composições e arranjos de relações com "aquilo que já existia no tempo de meu avô", em certo sentido, com aquilo que já era "dado". Dessa forma, Pai Paulo não se via como um "criador", como me disse certa vez, "sou um improvisador".

Os recados de Ifá implicam ainda em certa externalização dos conhecimentos de Pai Paulo (e de Ifá), da sua capacidade de escrever os versos de acordo com suas heranças espirituais e intuições. O objetivo dessa escrita era fazer com que Pai Paulo revelasse aos seus descendentes aquilo que diz Ifá em seus vaticínios e impedir que, ao morrer, esses 
conhecimentos novamente se perdessem - por isso ele sempre se referia ao desejo de ser um "ancestral do futuro". A escrita dos recados passava por essa prática divinatória.

Em meu mestrado, minhas reflexões se concentraram nos modos de composição dos versos de Ifá escritos por Pai Paulo Braz. Ifá é um sistema oracular de origem iorubána, que é baseado no manejo de dezesseis caroços de dendê, para obter uma combinação entre um conjunto de 256 signos gráficos denominados odus. Cada odu contém uma quantidade de versos ou recados que compõem seus significados. Ele foi dado como extinto no Brasil, em especial em Recife, onde seu desaparecimento datava no início do século XX.

A atualização de Ifá feita por Pai Paulo buscou recuperar elementos e práticas do universo nagô que desapareceram com a morte de seus antepassados. Ele passou a escrever os recados em um site próprio, que, contava satisfeito, tinha acessos do mundo inteiro. Assim, difundir esse conhecimento a um público maior é uma ampliação dos efeitos dos recados de Ifá em uma nova escala. Além disso, a atualização do jogo, mais do que o resgate de elementos "originais" recuperados de um passado, compõe-se de experimentações inspiradas nas continuidades e diferenciações relativas ao que foi "perdido" no passado e que agora retorna pela ação de Pai Paulo. Ao retificar ou atualizar esse conhecimento, Pai Paulo se singularizava frente a seus ancestrais, experimento feito por ele em outros contextos, como, por exemplo: ampliação do repertório de cantigas do nagô, novas invocações, intensificação de rituais antigos, entre outros.

Ao mesmo tempo em que tais ações diferenciavam Pai Paulo daquilo que estava "dado" com a morte de seu pai e tio, tais iniciativas eram uma oportunidade para Pai Paulo fazer as coisas ao modo como eram feitas no tempo de seus ancestrais. Estes últimos se situam como um ponto do qual partia Pai Paulo para "improvisar" e assim reverter seu pessimismo sobre o desaparecimento de tais práticas. Essa prática de manter viva a herança de seus ancestrais se confirmou $^{5}$ após a morte de Pai Paulo, na medida em que ele pode intervir e mediar a vida de seus descendentes, não mais como um intérprete do jogo, mas na forma do recado transmitido pelo jogo. Um ancestral do presente.

A partir dessa pesquisa sobre Ifá, minha atenção foi gradativamente se voltando para as formulações de Pai Paulo sobre seu processo de "atualização" do jogo em relação à sua

\footnotetext{
${ }^{5}$ Confirmação é a principal resposta afirmativa das técnicas divinatórias do jogo de búzios.
} 
transmissão pelo seu sangue. Dito de outro modo, como o sangue funcionava como um "meio" por onde passavam suas heranças espirituais. Pai Paulo dizia que não poderia ficar apenas na "leitura" do livro ou de cadernos - mesmo que eles contivessem todos os odus e seus recados. O jogo, para "funcionar", obriga a pessoa a compor, ela mesma, seus enunciados, a partir de sua experiência e intuição. Isso implica que o sistema não poderia ser ensinado, mas somente transmitido ao longo da vida de um iniciado no candomblé. Essa transmissão seria mediada também pelas heranças, um tipo de "dom"6.

Como dito acima, a atualização do jogo de Ifá, na visão de Pai Paulo, vem de sua herança espiritual e está vinculada a uma concepção de "consanguinidade" própria ao mundo dos candomblés do Recife. Essa "consanguinidade" pode ser entendida como um fundo de preexistência diante do qual a criação emergiria como figura. O sangue no candomblé é constituído por, e funciona como, o principal veículo de transmissão do axé, força que anima e movimenta o universo. O axé é também substância, e enquanto substância pode ser traduzido como diferentes modalidades de sangue, a exemplo da definição clássica de Juana Elbein dos Santos (1977):

\begin{abstract}
Pois esse sangue não é apenas o que nós mesmos chamamos de sangue: ele pode ser vermelho, branco e preto e ele se distribui entre os reinos animal, vegetal e mineral, gerando assim nove possibilidades das quais nós só retemos uma: "o 'sangue' vermelho [...] do reino animal: corrimento menstrual, sangue humano ou animal (Elbein dos Santos 1977:41 apud Goldman, 2009, p.279).
\end{abstract}

Embora reconheça a potência da definição do axé enquanto diferentes modalidades de sangue, elaborada por Juana Elbein dos Santos, não posso deixar de sublinhar minha leitura do axé, a partir do meu material etnográfico em Recife, de que não é possível estender ao axé uma classificação em formas tão marcadas, como, por exemplo, "tipos de sangue" em uma escala cromática de apenas três cores (preto, branco e vermelho). Essas poderiam ser cristalizações, sempre momentâneas, dessa força e não uma forma acabada da mesma. E, a exemplo do que argumentou José Jorge de Carvalho, considero a extensão dessas classificações desajustadas ao contexto do candomblé do Recife, concordando com o que escreveu o autor: "[o]significado da palavra está se tornando uma espécie de conceito analítico universal, usam axé quase que como um sinônimo daqueles termos clássicos tais como mana, manitu, e assim por diante. Não insisto

\footnotetext{
${ }^{6}$ Essa é uma discussão que tem chamado a atenção de diversos antropólogos/as na etnologia afro-brasileira (cf. Boyer, 1996; Halloy, 2010; Goldman, 2012; Sansi, 2009, entre outros). Espero, ao longo desta tese, contribuir para esse debate a partir do meu material etnográfico sobre a relação entre dom e iniciação.
} 
nesse último sentido do termo com muita ênfase nesta tese porque ele não corresponderia ao seu emprego geral no Recife" (Carvalho, 1984, p.111).

A composição de diferentes substâncias é central nos rituais do candomblé, sendo o sangue a principal delas. O sangue dos animais é o meio privilegiado de diferentes participações entre homens e outros seres: divindades, espíritos e pessoas. É o sangue que alimenta uma divindade e fortifica o vínculo entre uma pessoa e seu orixá. O sangue também demarca um vínculo criado ritualmente, sendo, portanto, um modo de relação.

"Entre nós, o sangue reina", costumava dizer Pai Paulo. É essa noção de consanguinidade que explica como os membros da família de Pai Paulo se percebem como únicos e singulares em relação às outras casas de candomblé. Esse poder do sangue e dos laços de consanguinidade também é expresso como a parte do sangue; expressões que utilizarei como sinônimos no decorrer da tese. É a força do sangue que permite certas execuções ritualísticas, formas específicas de cantar, domínio de técnicas rituais e o modo como as casas de santo se organizam.

Contudo, é necessário dizer que formulações e ações rituais expressas pelo idioma do sangue não são exclusivas a Pai Paulo, ou restritas apenas à sua família, mas um recurso comum do povo de santo do Recife para elaborar sua experiência religiosa. No caso da familia Felipe da Costa, devemos reconhecer que tal experiência ganha dimensões adicionais, tendo em vista, por exemplo, a reconstituição da linha de ascendentes até seus ancestrais africanos, o que, como veremos, oferece uma força espiritual diferenciada. Não é demais lembrar que essa possibilidade de reconstituição infelizmente é raríssima em grande parte das famílias negras no Brasil.

Assim, as elaborações de meus anfitriões sobre o modo de vida do candomblé em Recife, quase sempre, fazem referência e se baseiam nas relações de parentesco. Não apenas em diálogos comigo, a respeito de meus interesses de pesquisa, mas, principalmente, nas suas próprias conversas e debates. Religião e parentesco seriam, para essas pessoas, coextensivos. Desse modo, meu interesse de pesquisa, antes voltado para os procedimentos rituais e técnicas oraculares, paulatinamente foi transferido para as formulações sobre a produção do parentesco em terreiros do candomblé nagô.

\footnotetext{
${ }^{7}$ Uma constatação frequente no interior dessa família de santo, formulação que nomeia um artigo de Arnaud Halloy (2010), importantíssimo para esta tese: “'Chez nous, le sang règne!'.L'apprentissage religieux dans le culte xangô de Recife".
} 


\title{
A FAMília Felipe da Costa
}

A noção de "família" denota uma vasta rede de terreiros que possuem filiação com Sítio de Pai Adão, o Ilê Obá Ogunté, um dos mais importantes e antigos terreiros do Brasil. Sua fundação remonta ao início da década de 70 do século XIX, por uma nigeriana: Inês Joaquina da Costa, cujo nome africano era Ifátinuké, filha de Iemanjá Ogunté, trouxe os principais assentamentos da casa, plantou o pé de Iroko, e outros fundamentos. Ela teria vindo da África como africana liberta, e se instalado na então região do Baixo Beberibe ${ }^{8}$. Pai Paulo afirmava que ela teria vindo da cidade nigeriana de Ilê-Ifé:

\begin{abstract}
Antigamente, os iorubás, ou lucumi, como se dizia, vieram da África, mas foram obrigados a vir no navio negreiro, e aí se misturou os negros das tribos diferentes, nagô, jeje, xambá. Tia Inês, por exemplo, ela era de Ilê-Ifé, o rei disse que era uma família muito importante de lá, mas ela também era jeje, uma moça disse que ela era de Abeokuta, que nada, ela era jeje, tinha aqueles 3 traços no rosto. Assim como Claudino Bamboxê, que foi um dos principais auxiliares dela no Sítio. O Sítio é nagô, nossa tradição é nagô, mas ele era jeje, tem até aquela toada de Ifá, a gente canta de um jeito e o jeje canta de outro. Não é esse jeje que você vê nos terreiros por aí não, era diferente mesmo. Meu pai cantava muitas toadas do xambá, ele gostava ele cantava 'Ogum torubamba torubamba', essa é uma toada do xambá, outra vez ele foi num terreiro e quase apanhou do povo, houve uma confusão medonha, ele cantou aquela toada xambá 'Akoro pa loni o pa o jare pa lelé pa Ogum pa ojarê', ele estava dizendo que era para Ogum limpar, abrir os caminhos, né, só que pra mãe de santo ele estava mandando Ogum matar todo mundo (risos). Mas é tudo africano mesmo (Filho, 2015, p.132).
\end{abstract}

De acordo com Pai Paulo, o Sítio era conhecido como "Sítio de Inês". Posteriormente recebeu o nome Sítio de Pai Adão, mudança atribuída à popularidade de seu avô Felippe Sabino da Costa, Adamassi, popularmente conhecido como Pai Adão Ope Atonan. Filho de Iemanjá, nascido em 1877 no Engenho Taquarí (atual bairro da Torre), tinha como pai Sabino da Costa, Alapini Oyo Oba, (Fernandes, 1937, p. 56). Adão teria viajado e residido em outras cidades, como Salvador e Maceió, chegando inclusive a viajar para África. Assumiu o Sítio alguns anos depois da morte de Tia Inês, liderando essa casa até 1936, quando faleceu.

A partir daí ocorreu uma série de sucessões envolvendo famílias de santo e de sangue, com proeminência desta última, de modo que hoje o Sítio é liderado por um de seus netos, Manuel Nascimento Costa (doravante Manuel Papai), filho de José Romão, e primo de Pai Paulo. Antes de Manuel, José Romão e Malaquias, respectivamente, dirigiram o Sítio até a década de 70. Com a morte do primeiro, Manuel reivindicou o direito à propriedade do terreiro,

\footnotetext{
${ }^{8}$ Sobre sua história ver Carvalho (1987), Halloy (2005) e Motta\&Brandão (2002).
} 
uma vez que ele "herdara" as terras ${ }^{9}$. Essa reivindicação gerou um conflito entre Manuel e seu tio Malaquias, e terminou com a saída deste do terreiro e a fundação do Ilê Iemanjá Ogunté, como retrataram os trabalhos de Motta (1988), Carvalho (1987) e Halloy (2005). Os efeitos dessa saída são sentidos até hoje e refletem a relação entre o terreiro do Ilê Oba Ogunté e o Ilê Iemanjá Ogunté.

Até dezembro de 2016, Pai Paulo e Mãe Lu dirigiam o terreiro Ilê Iemanjá Ogunté, fundado em meados da década de 1970, onde zelam pelos orixás da família, dando continuidade à tradição do pai, Malaquias Felipe da Costa.

Malaquias Felipe da Costa, Ojébii (1909-1984), era considerado um exímio cantor e dançarino no nagô. Foi pai de santo de um grande número de casas nagô, tendo, portanto, muitos filhos e filhas de santo. Aposentou-se como contínuo no prédio da Receita Federal, em Recife, e tinha sua formação como marmorista. Malaquias era filho de Iemanjá, fundador do Ilê Iemanjá Ogunté e, principalmente, da família de santo, seu egum ${ }^{10}$ é o lider do balé (igbale espaço destinado aos mortos) do terreiro. José Jorge de Carvalho, assim o descrevera:

\begin{abstract}
Maior conhecedor de todo o seu sistema ritual, melhor cantor e quem melhor pronunciava a língua iorubá. Com sua morte, o Nagô perdeu uma parte considerável do culto a Orumilá (era ele o que mais sabia sobre esse ritual), incluindo uma parte considerável do repertório dos cânticos a este orixá. Além disso, a língua iorubá, na qual se fazem todas as invocações e todos os cânticos, ficará mais distorcida ainda do que já está, pois pouquíssimas pessoas são ainda capazes de pronunciá-la de forma reconhecível. Malaquias provavelmente levou consigo outros "fundamentos" importantes do culto, apesar de segundo fui informado ter deixado ainda instruções com os filhos e o neto (Carvalho,1987, p. 45).
\end{abstract}

Leônidas Josefa Felipe da Costa, Omiseun, era uma grande juremeira, qualidade herdada de sua mãe. A parte da Jurema da família é considerada como uma descendência dela. Seus herdeiros contam que Dona Leônidas era filha de santo de Pai Adão, mas que ele recomendou que ela não se iniciasse no candomblé e fizesse apenas obrigações ao santo, porque sua parte da Jurema era muito forte e seu ori $^{11}$ não aceitava que ela entrasse em demasia no universo dos orixás. De todo modo, essa evitação permaneceu até a sua morte, tanto é que, em seu axexê (cerimônia fúnebre), ela pediu que não cantassem o repertório dos eguns.

Malaquias e Leônidas tiveram seis filhos: Sebastião Felipe da Costa (Baixa) Agbalalulu, Paulo Braz Felipe da Costa, Ifatoogun Ifamuyide, Maria José Felipe da Costa (Tia Zite) Oyin

\footnotetext{
${ }^{9}$ Discuto esse evento mais detalhadamente no quarto capítulo da tese.

${ }^{10}$ Espirito dos mortos.

${ }^{11} \mathrm{O}$ ori é entendido como simultaneamente a cabeça física e espiritual de uma pessoa.
} 
O $\underline{s} u n$, Jaci Felipe da Costa (Cicinho) Obarinde, Maria dos Prazeres Felipe de Barros (Tia Zeres), Omojare, e Maria Lúcia Felipe da Costa.

Maria Lúcia Felipe da Costa, Omitoogun, doravante Mãe Lu, acolheu-me em sua casa desde o primeiro dia em que nos conhecemos. Convidando-me para entrar, levou-me até a cozinha, perguntando sobre Jorge [José Jorge de Carvalho] e procurando saber sobre o que eu estava estudando. Quando pôde, Mãe Lú me ensinou sobre a vida. Esteve sempre ao lado dos pais, Malaquias e Dona Leônidas, cuidando deles por toda a vida. Teve uma filha consanguínea, Bárbara Lúcia Nascimento da Costa. E criou ainda um grande número de filhos, como Paulinho e Bino, Júnior e Marcio, filhos de seus irmãos; além de alunos e filhos de conhecidos. Agora ela cuida de seus netos Thauany, Thalyson e Thalita. Em seu guarda-roupa, em meio a embrulhos, contas e peças de roupas, guarda as lembranças estampadas nas antigas fotografias, a carteira de identidade de seu pai, Malaquias, e o registro do terreiro. É seu cofre pessoal: “eu guardei tudo o que era de meu pai e de minha mãe”. Com a morte de Pai Paulo, Mãe Lu passou a custear todas as despesas da casa com sua aposentadoria de professora. É uma das poucas de sua geração a ter cursado o nível superior, sendo graduada em Letras, com especialização em História da África. Mãe Lu também participa como mestra do projeto "Encontro de Saberes", na Universidade de Brasília.

Tia Zite, Oyin Os $\underline{u}$, falecida em janeiro de 2018, possuía uma casa de santo em Olinda, no bairro de Jardim Paulista. Dividia a liderança da casa com seu filho, José Américo Gonzaga Júnior, doravante Juninho ou Junior de Oguian. Acompanhei alguns rituais e festas em sua casa. Era filha de Oxum e possuía um grande número de filhos de santo. Sua Oxum era tida como uma das mais belas de toda a cidade. Com a sua morte, seu filho continuou à direção de sua casa.

Com a morte de Pai Paulo, quem assumiu a direção do Ilê Iemanjá Ogunté, foi Tio Cinho, ou Cicinho, Obarinde. Filho de Xangô, Tio Cinho é muito popular entre os terreiros do Recife devido ao seu bom humor e jeito gozador. Poucos anos atrás, Tio Cinho perdeu a visão em decorrência de complicações da diabetes. Isso o deixou bastante amargurado, mas, mesmo com a doença, ainda possuía um grande número de filhos de santo e exercia o ofício como pai de santo em, ao menos, quatro casas de culto.

Na casa de Mãe Lú, onde também fica o terreiro, compartilhei do convívio dos filhos mais velhos de Pai Paulo, Felippe Sabino da Costa (doravante, Bino) e Paulo Braz Felipe da Costa Filho (Paulinho). Bino, filho de Olufã, herdou os objetos de Ifá de Pai Paulo. É casado com Valéria, uma das filhas de Dona Zetinha, mãe de santo de um terreiro em João Pessoa, 
onde ele atualmente reside. Além dos objetos, Bino herdou grande parte das casas que tinham Pai Paulo como pai de santo. Ele conta hoje com um grande número de terreiros e filhos de santo, além de oficiar diversas obrigações específicas noutras. Seu trabalho como pai de santo é requisitado em muitos terreiros de Recife, João Pessoa, Natal e até mesmo em Fortaleza.

Paulinho, filho de Orixá Oguian, é o filho mais novo de Pai Paulo. É um dos principais ogans da rede de terreiros do nagô e sempre requisitado pelas outras casas para trabalhar em seus rituais. Possui um grande número de afilhados e poucos filhos de santo. Pai Paulo elogiava em Paulinho a perfeição de seu iorubá e o modo como ele canta. De personalidade introspectiva, é muito comedido em seus atos. Recentemente tem assumido a liderança de algumas obrigações. Essa timidez só foi superada quando ele assumiu o papel de cantar. Sua voz é belíssima e, em muito, lembra o modo como Pai Paulo cantava e dançava, características que se acentuaram após a morte deste último.

Da família, meu maior convívio se deu também com os dois filhos de Tia Zeres, ambos com trinta e poucos anos, Marcio Felipe de Barros e Orlando Felipe Barros (doravante, Junior Boto).

Marcio atua como músico em diversos grupos percussivos da cidade e no Maracatu Estrela Brilhante. Ele é filho de Ogum e um dos principais ogans da família.

Junior Boto, Obatunde, é um dos pais de santo mais conhecidos e respeitados de sua geração. Filho de Xangô, é muito carismático e divertido. Grande parte dos seus filhos de santo são percussionistas do Maracatu Estrela Brilhante. Seu trabalho como pai de santo é muito valorizado. Ele tem uma das melhores vozes do nagô e um conhecimento profundo sobre as técnicas rituais do candomblé. Atualmente tem muitos filhos de santo na casa, e sua presença é constante no terreiro. Reside com a mulher e seus cinco filhos no Alto José do Pinho, bairro contíguo à Água Fria.

Outro pai de santo da família é José Iguaracy Felipe da Costa, mais conhecido como Pai Guara, Oxum Otoky. Filho de Sebastião e Elvira Soares da Costa, e neto de Malaquias, Pai Guara, após a morte de Pai Paulo, é o mais importante pai de santo da rede de terreiros que compõe a família de santo. Ele tem uma casa, o Ilê Oguiã Olabomaxó, na Cidade Tabajara em Olinda, e se destaca pelo intenso calendário ritual. Pai Guara foi iniciado por seu avô Malaquias no Sitio de Pai Adão, no final dos anos 70. Atualmente seu pai de santo é Severino Ramos, Tata Raminho de Oxosse. Divide com Tio Cinho a liderança dos principais rituais do Ilê Iemanjá Ogunté. 
Assim, tal como outras casas nagô, essa família se organiza em terreiros liderados por pais e mães de santo, formando extensas redes de casas de santo por meio de famílias genealógicas vinculadas às nações de origem. As famílias de santo das quais fazem parte as pessoas acima elencadas e as que descreverei abaixo, como bem apontou Halloy, funcionam como uma rede, "a rede nagô" (2005, p. 131), que é nomeada pelos praticantes do candomblé em Recife como rama.

Idelfonso, filho de Orixalá, é descendente de uma família de nigerianos que participaram da fundação do Sítio. Teve sua conta lavada por Malaquias no final dos anos 70 e fez seu santo com Pai Paulo e Isaura, uma antiga mãe de santo e filha de santo do Sítio. É formado em Geografia pela UFPE e funcionário dos Correios. Reside atualmente em João Pessoa e frequentemente vem ao Recife. Integra o conselho interno ao Sítio, atinente à sua gestão enquanto patrimônio cultural de Pernambuco. É profundo conhecedor de muitas histórias do nagô. Um dos meus principais amigos em Recife.

João Pereira, mais conhecido como Dão, filho de Oxum, é um dos poucos pais de santo branco da rede de terreiros que compõe a família de santo. Tem sessenta e poucos anos de idade e mais de 40 anos de iniciado. Sua casa se localiza na Linha do Tiro, bairro da Zona Norte do Recife. Não realiza toques em sua casa, apenas obrigações. É padrinho de santo de grande parte da segunda geração do terreiro.

Dona Zetinha, filha de Iansã, é antiga filha de santo de Pai Paulo. Seu terreiro é em João Pessoa, onde Pai Paulo oficiava como pai de santo até a sua morte. Atualmente Bino oficia as obrigações cotidianas e Guara realiza as grandes obrigações da casa.

A antiga Casa de Dona das Dores é atualmente dirigida por Tia Edna. Essa casa foi fundada por volta dos anos de 1950, no bairro de Linha do Tiro. Após a ida de Mãe das Dores para São Paulo, seu filho adotivo, Roberto, assumiu a casa e a dirigiu até 2013, quando foi assassinado dentro dos aposentos do terreiro. Assim, a direção da casa passou para Tia Edna, antiga filha de santo de Das Dores.

Vandinho, filho de Orixalá, é filho de santo de Tio Cinho. Tem aproximadamente 25 anos de iniciação. Ele trabalha como agente de saúde no município de Recife e cursa enfermagem. Possui uma casa de santo no Córrego do Deodato, bairro de Água-Fria.

Todas essas casas são descendentes do Sítio, mas se consideram, principalmente, descendentes de Malaquias. Localizam-se na zona norte da cidade do Recife, e todas estão num raio não maior do que 10 quilômetros de distância entre si. 
Um dos objetivos dessa tese é perseguir etnograficamente os desdobramentos da explicação dada pelos praticantes do candomblé do terreiro sobre seu "parentesco". Nesse sentido, focalizo certas composições que se expressam por meio do parentesco, tais como iniciação, transmissão de nomes, de objetos rituais, de assentamentos, das capacidades intuitivas e criatividade, que conformam heranças espirituais nas quais o sangue surge como um vetor e uma composição.

Como afirma Halloy, “a família de santo delimita um campo de relações preferenciais expresso no vocabulário da consanguinidade" (2005, p.32). Na mesma direção, vários estudiosos das religiões de matriz africana reconhecem a relação mãe de santo ou pai de santo e filhos de santo como centrais na constituição das famílias de santo nas casas de candomblé. Esses termos vêm acompanhados ainda de outros em um idioma que não o português. No caso do nagô, é conhecido, mas não usual, o uso dos termos baba ou iya (pai e mãe em iorubá) como uma contração da palavra babalorixá ou iyalorixá. Podemos considerar como termos mais elementares das relações entre uma família de santo: pai e mãe, filho e filha. Usa-se também os termos irmãos e irmãs, tios e tias, que, embora relevantes na perspectiva dos terreiros, não são da mesma importância ritual dos primeiros, mas aparecem como importantes e frequentes termos referenciais entre os membros da familia consanguinea.

Todos os laços entre as pessoas descritas nesta seção, como veremos nesta tese, passam por processos iniciatórios que, por sua vez, operam como um modo central de produção de parentesco. A iniciação não apenas envolve, mas cria os dois termos desse universo de referência: sangue e santo, instaurando uma diferenciação em relação à linha de consanguinidade que atravessa essa rede dos terreiros.

Pretendo, nesta tese, descrever os modos de composição e criação do "parentesco" no terreiro Ilê Iemanjá Ogunté e sua rama. Busco evitar certas oposições encontradas na literatura antropológica, que situam de um lado o parentesco considerado como "real" ou "consanguíneo" e de outro o parentesco "de santo" como "parentesco fictício" ou "ritual" (Motta, 1987; Segato, 1984, Ribeiro, 1958, entre outros). Minha principal preocupação é não tomar a nossa imagem de consanguinidade como autoevidente, para, então, pensar "família de santo" como uma derivação dela.

Meu ponto de partida é a distinção (e não oposição) estabelecida pelos integrantes do terreiro, entre sangue e santo. Ou seja, o que consideramos como "parentesco de santo" é 
transmitido pelo "parentesco de sangue", e o "parentesco de sangue", por sua vez, também incide no "de santo". A proximidade e o afastamento dessas duas linhas se expressa a partir da interdição ritual de que um pai ou uma mãe carnal $^{12}$ não poderia ser pai ou mãe de santo de um filho, tanto porque ninguém é pai ou mãe duas vezes, mas também, e principalmente, porque misturaria as energias. Como veremos, esse modelo relacional se replica, em diferentes escalas, em outros aspectos do candomblé nagô.

\section{A FAMÍLIA DE SANTO NA LITERATURA AFRO-BRASILEIRA}

Apesar da centralidade da "família de santo" no universo do candomblé, na história da etnologia afro-brasileira, nota-se uma ausência de estudos relacionados ao campo do parentesco. As objetivações antropológicas sobre o tema não tiveram grande desenvolvimento. Com exceção da clássica dissertação de Vivaldo da Costa Lima de 1977, “A família de santo nos candomblés jejes-nagôs da Bahia", os principais (e ainda poucos) trabalhos que exploram o assunto, se concentram, sobretudo, nos anos 60 e 70 do século passado.

A literatura sobre os candomblés sempre ressaltou, ao falar da configuração familiar das casas de culto, como a questão do "sangue" e do "santo" se apresenta enquanto uma diferenciação inerente ao universo dos terreiros.

Mais ainda, partilhava do pressuposto de que os terreiros estão envoltos por um mecanismo da sociedade envolvente, a partir de uma relação necessariamente de dominação de um termo pelo outro. Com efeito, essa antinomia é a replicação de outra fundante, por exemplo, sociedade/indivíduo. A diferenciação entre santo e sangue, concebida de maneira a reforçar uma dualidade, é efeito de um binarismo anterior. Tudo nos leva à assertiva de Marilyn Strathern, quando diz que "a mera aproximação dessas falas nos permite assumir como verdade que, em suas diferentes versões, elas se referem ao mesmo problema" (Strathern, 2006, p.63). O próprio parentesco de santo é tido como um domínio destacado.

A questão que me parece central nesse debate é: o modo usual de descrever tal relação acaba por situá-la como uma oposição, que possui longa trajetória disciplinar. Tal trajetória remete-nos até as oposições fundantes, como entre "sociedades do status", onde a

\footnotetext{
${ }^{12}$ Nos candomblés costuma-se marcar a relação entre pais e filhos consanguíneos pelo termo "carnal” ou "parentes carnais". Em Recife, é comum as pessoas se referirem aos pais ou filhos consanguíneos como "minha mãe carnal”, "meu filho carnal". Essas frases são evocadas para marcar a relação de consanguinidade em relação ao contexto da família de santo. Para se referir aos ascendentes diretos consanguíneos, em geral, usa-se o termo carnal em vez de sangue, ainda que eventualmente possa se falar em termos de mãe ou pai de sangue.
} 
consanguinidade possuiria um valor proeminente, e aquelas "sociedades do contrato", nas quais a "família" em seu "núcleo doméstico" se opõe ao "espaço público" e político. Em suma, minha hipótese é que a oposição construída entre santo e sangue na literatura antropológica das religiões de matriz africana é uma atualização da relação entre consanguinidade e contrato feita nos primeiros estudos do parentesco e organização social.

Minhas abordagens nesta tese refletem o desejo de evitar estratégias conceituais que tendem a relegar os entendimentos do nagô a meros "dados", tratando seus "teóricos" como meros informantes. Pretendo não neutralizar a alteridade desses entendimentos, ao formatá-los, previamente, dentro das nossas categorias analíticas. Isso implica em examinar as relações entre antropologia e as elaborações de nossos anfitriões.

Um bom ponto de partida para introduzir a discussão sobre família de santo é a dissertação de Vivaldo da Costa Lima sobre a família de santo no candomblé da Bahia. Ancorada em um trabalho de campo de longa duração, e feita com mais de 23 terreiros na capital baiana, suas questões movimentam-se entre o caráter "estrutural funcionalista" dos modos de organização da vida social dos terreiros por ele estudados. Uma das proposições mais gerais de Costa Lima diz respeito à exclusão, ocorrida no Brasil, da "família de sangue" pela "família de santo". Segundo o autor, ao entrar na "família de santo", o iniciado ganharia uma nova família que substituiria a de "sangue". Esse é um argumento importante de reter. Tal afirmativa só é possível por assumir que "famílias negras", ou de "baixa renda", seriam "desestruturadas" segundo os valores da "sociedade envolvente". Como efeito dessa "desestruturação", as famílias negras sofreriam um aprisionamento conceitual dentro de um duplo caso de "adaptação": no primeiro caso seria, como veremos, uma adaptação dos negros escravizados à família patriarcal branca; no segundo, uma adaptação de estilos e padrões africanos que sobreviveriam no Brasil. Variações desse argumento são encontradas em trabalhos subsequentes sobre a família de santo.

De certo modo, nos deparamos com estratégias analíticas dessa tradição intelectual, que pensa as religiões afrobrasileiras como expressão de uma relação mais fundamental, a exemplo das etnografias africanas, que seria o parentesco. A comparação entre o contexto brasileiro e o africano torna implícito outro tipo de operação com os dados etnográficos, uma espécie de impulso, ao presumir como realidades objetivas os dois registros ${ }^{13}$ teóricos do campo do parentesco. Tais formulações passam necessariamente a apresentar esses pressupostos e operacionalizá-los nas discussões sobre a família de santo.

\footnotetext{
${ }^{13}$ Notadamente as noções de filiação (e descendência) e de aliança.
} 
Devemos a Schneider $(1965 ; 1984)$ uma primeira revisão metodológica dos nossos pressupostos sobre parentesco, ao trazer para o centro do debate não mais a pertinência, ou não, dos modelos, em especial as discussões de que o parentesco se basearia, primeiramente, na genealogia como uma base biológica e sobre a qual se constituiria uma representação social; ou ainda, a do parentesco como expressão social, que refletiria, na mentalidade das pessoas, natureza, sociedade e cultura. Segundo Schneider, o "parentesco" funcionaria como um tipo de "artifício", por meio de projeções e assunções de modelos cada vez mais especializados (enquanto fundo), sobre os dados etnográficos cada vez mais dispersos (enquanto figura) - os efeitos de tais projeções seriam o de tomar o parentesco não mais como uma hipótese, mas, enquanto uma "realidade" (agora figura) nas descrições etnográficas (fundo), tal contraste desapareceria na medida em que seria revelado. Tudo se passa como se os modelos teóricos e os dados etnográficos tivessem a aparência de ser a mesma coisa nessas projeções.

Voltando à introdução de Costa Lima, o autor aponta para o que define como "sistemas empíricos": a família de santo e os laços de parentesco estruturados em bases sóciobiológicas, e a sociedade global em que os dois sistemas se inserem. É curioso notar, como mostrarei mais à frente, que os trabalhos sobre a família de santo, ao menos parcialmente, organizam suas análises dentro dessa tríade, centrados entre um sistema formado pela família de santo, a família consanguínea e a estrutura social mais ampla. De todo modo, o estudo de Lima enfatiza as dimensões classificatórias do parentesco de santo, da sua estrutura e sua hierarquia, sempre a partir do que ele entende como papéis sociais dos membros do terreiro:

As religiões iniciáticas africanas que marcaram o candomblé brasileiro eram, sobretudo, religiões de linhagens ou de tribos em que a instituição da família desempenha um papel preponderante $[\ldots][\mathrm{N}]$ o candomblé, nas linhagens recriadas através dos laços da descendência mística do culto aos orixás, também se obedece, com maior ou menor rigor, às interdições das sociedades unilineares (Costa Lima, 1977, p.179).

Esse recorte do autor insere a questão da solidariedade tida como base para a formação e manutenção do grupo, um formado a partir do relacionamento de pais e mães de santo com seus filhos de santo e desses entre si. O elemento que embasa essa questão é principalmente a onomástica vocativa de "pai" ou "mãe" advinda da relação estabelecida com seus filhos no momento da iniciação. Um tipo de paternidade classificatória na qual o conceito de família biológica cederia, por motivos externos, seu lugar a outra de natureza distinta, neste caso, a família de santo. Nesta figuraria a mãe de santo como autoridade máxima do grupo, a chefe da família de santo. 
Essa abordagem possui, ainda, como horizonte teórico, por um lado, as discussões sobre descendência e organização social centrados na etnologia africana da época, e, por outro, o vínculo dos terreiros no Brasil com a África, onde a família de santo e a família de sangue seriam a mesma família (cf. Bastide 1958, Verger, 2002), dado que os orixás pertenciam a uma linhagem paterna pela qual eram transmitidos. Costa Lima oferece uma importante mudança teórica relativa à leitura dos materiais etnográficos e históricos oriundos dos povos iorubá e fon, afirmando que a relação entre terreiros brasileiros e África deve ser entendida em termos de influência, e não permanência, dado que no território africano os ditos sistemas religiosos estariam intimamente ligados a outros dois sistemas, o de parentesco e a linhagem familiar, e, segundo um dos pressupostos funcionalistas, seria natural e obrigatório que os membros da linhagem representem seu "grupo" no sistema religioso.

Essa ênfase ou tensão entre os dois sistemas atravessa todo o trabalho de Costa Lima. Sua afirmação peremptória da substituição da família consanguínea pela de santo é parte central de seu argumento. Contudo, há inúmeras passagens etnográficas que, se não chegam a negar totalmente o argumento, tornam a situação mais complexa ao evidenciar uma quase indiscernibilidade entre os dois modos, como o autor mesmo demonstra:

\begin{abstract}
Mas sempre é certo que pertencer a uma família que é de candomblé, isto é, ser socializada num grupo familiar que tem no candomblé o seu sistema de crença religiosa; ter em seu processo 'inculturativo' a visão constante da presença do orixá tantas vezes presente no corpo de uma mãe ou de uma irmã de sangue [na nota que segue ao termo de sangue o autor explica que a expressão irmã ou mãe de sangue se opõe, na linguagem do candomblé, ao de santo. Diz-se também irmã ou mãe de carne] se criado num ambiente em que predominam os valores, e as normas de conduta subsumidas as sanções sobrenaturais dos orixás - tudo isto já predispõe a pessoa, de um ponto de vista não apenas cultural ou linearmente psicológico, à crença e participação efetiva no culto (Costa Lima, 1977, p.62).
\end{abstract}

Essa formulação nos remete àquelas já clássicas sobre o estatuto da noção de "família", tendo como fundo conceitual a noção de "grupo". O binômio família/casa funcionaria, nessa inferência, como reflexo de uma "organização social" em menor escala, encarnadas em seus membros as derivações que a tipificaria enquanto promotora das relações de produção, de solidariedade e de tensões e cisões, como reflexo de dinâmicas sociais pregressas.

Tais pressupostos sociológicos dessa concepção de família são encontrados argumentum ad nauseam nos discursos e teorias sobre a formação nacional, da qual a família figuraria como uma espécie de "instituição" com reflexos jurídicos e políticos sobre e contra a "sociedade". Essas teorias contam com toda uma tradição intelectual no campo das teorias 
sociais brasileiras, tendo como um dos trabalhos percussores a obra "Casa Grande e Senzala" de Gilberto Freyre ([1933]1977).

Freyre se dedica em seu livro a escrever uma nova orientação sobre a formação do Brasil a partir do estudo sobre a "família brasileira", em especial sobre a família patriarcal fundada na casa-grande. A senzala era, para ele, uma continuidade das relações de poder engendradas por esse patriarcado, por meio de agregações parciais e subalternas ao núcleo conjugal dos senhores, desenvolvidas e, como sabemos, submersas em violência. Louis Marcelin (1996), em uma crítica certeira à formulação freyriana, demonstra como essa visão totalizante, apenas inaugurada por Gilberto Freyre e continuada por outros estudiosos, expressa pelo sintagma casa-grande/senzala, do qual o último termo é apenas um agregado do primeiro, "criou uma versão excessivamente verticalizada e monolítica do regime de plantation”, e, principalmente, criou uma noção de que não haveria família de escravos, mas "escravos participando da vida do senhor", retratando os negros desprovidos de qualquer autonomia (Marcelin, 1996, p.52).

$\mathrm{Na}$ esteira desses debates, o estatuto da família negra continua no cerne do debate antropológico, em especial os realizados por antropólogos norte-americanos em Salvador, na virada dos anos 30 e 40. Em vez da permanência do modelo jurídico português da família patriarcal, o que motivou o debate nesse período foram as elaborações sobre a permanência ou não de estruturas africanas na formação dos grupos familiares negros. Esse debate tinha como pano de fundo o contraste entre a integração racial dos negros nos EUA e Brasil e a influência ou não de traços estruturantes africanos na organização dessas famílias. As informações que embasavam esse debate foram extraídas do mesmo contexto: comunidades negras de Salvador, em especial, famílias que faziam parte da comunidade do terreiro do Gantois.

Para Franklin Frazier (1942, 1943), importante sociólogo norte-americano, a estrutura familiar negra e seus aspectos culturais seriam produtos da escravidão e, por consequência, uma adaptação a situações de pobreza e violência nas quais os negros baianos estavam submetidos. Segundo o autor, esses fatores levavam ao desagregamento das famílias, fazendo permanecer, então, apenas os laços mais duradouros dos núcleos familiares, qual seja, a relação entre a mãe e seus filhos.

Em direção oposta, o antropólogo Melville Herskovits (1943, 1945, 1990) defendia que essa configuração da família negra brasileira advinha da permanência de formas tradicionais culturais e de vida africanas adaptadas ao novo mundo. A relação entre mães e filhos são, nesse sentido, centrais nas famílias negras como prova da tenacidade e sobrevivência do lugar da maternagem nas sociedades do oeste africano, comuns em sociedades de linhagens patrilocais 
e poligâmicas, nas quais a organização social das linhagens se dava pela descendência dos filhos de várias mulheres com o mesmo homem, o que tornava a relação, do ponto de vista dos filhos e das relações de afetividade, mais proeminente na relação entre uma mãe e um filho.

Essa divergência foi explicitada em uma discussão em artigos publicados no início dos anos 40, na American Sociological Review. Apesar de antagônicas, tais posturas se inseriram no contexto de combate ao racismo norte-americano. De um lado, valorizavam-se os aspectos culturais africanos e sua capacidade de resistir à adaptação imposta pelo mundo branco, e do outro, o destaque da não singularidade das comunidades negras no novo mundo e o caráter eminentemente social de sua situação, portanto passível de ser revertido com a melhora de sua condição social e econômica.

A partir dos anos 70, outro ciclo de pesquisas sobre a "família de santo" se consolida (Silverstein, 1979; Segato, 1984, 2000; Dantas, 1989). Nestes novos trabalhos, em consonância com a emergência de uma perspectiva sociopolítica para a análise das religiões afro-brasileiras, procura-se ver a família de santo não mais como a imagem de uma sobrevivência africana, e sim como resultado da influência da "sociedade envolvente". Em certo sentido há uma continuidade do argumento de Franklin Frazier, mas agora não se trata mais de uma ação dessas comunidades frente aos efeitos da escravidão, mas de um procedimento ativo das casas de candomblé em recompor suas famílias perante a experiência da escravidão e do patriarcado.

Partindo da crítica feminista sobre os estudos de parentesco (Rubin, 1975; Rosaldo, 1980), esses trabalhos buscavam explicar a família de santo em relação à "família patriarcal”, buscando na figura da "mãe de santo" a explicação para a relação entre candomblé e "sociedade envolvente":

\begin{abstract}
A mãe-de-santo, como mãe da família-de-santo, se situa aparentemente dentro da definição social contemporaneamente predominante de mulher: uma fêmea biológica que preenche o papel de esposa e mãe dentro da instituição da família. A familia-desanto não é sinônimo de família nuclear normativa, ainda que as vezes é interpretada como tal. Ela é uma família ligada por laços de parentesco ritual, ao invés de sangue e casamento, e é também um tipo de comunidade, um grupo doméstico. Nestas comunidades as mulheres negras e pobres assumem e mantém posições de poder e dominação sobre, entre outras pessoas, homens brancos de classe média e, menos frequentemente, alta. Então, o Candomblé serve de máscara e espelho da ideologia dominante na sociedade brasileira, assim como das redes materiais que a sustentam. O Candomblé se reproduz incorporando novos membros à família-de-santo em linha de parentesco ritual com vários graus de comprometimento. É neste sentido que podemos considerar a mãe-de-santo uma mãe de todo mundo (Silverstein,1979, p. $55)$.
\end{abstract}

Seguindo essa argumentação, Rita Segato (2000), por exemplo, destaca o esforço de libertação, por parte dos membros do xangô pernambucano, das categorias ideologicamente 
dominantes na sociedade patriarcal, como as categorias de gênero, de família e sexualidade. A exemplo de Silverstein, a interpretação de família pode ser pensada em separado dos papéis de gênero presentes no candomblé. Essa constatação é o que informa sua análise e serve como ponto de partida para interpelar o pouco ou nenhum destaque dado no candomblé ao matrimônio, entendido, para ela, sobretudo, como instituição social. Podemos exemplificar seu argumento nesse trecho:

Como uma unidade social, a família-de-santo coloca ao alcance dos seus membros um sistema de parentesco alternativo que é organizado e estável, apesar de ser bastante esquemático, o que libera as pessoas da incerteza de terem que depender unicamente da cooperação e solidariedade das relações de parentesco legítimo, que são, geralmente, frágeis e pouco articuladas. Neste sentido, a família-de-santo simula uma família afro-americana simples e internamente confiável, já que se apoia em sanções sobrenaturais e é ritualmente legitimada. Em alguns casos, quando o membro provém de uma família bem constituída nos termos da ideologia dominante na sociedade brasileira, a família-de-santo funciona como uma extensão daquela, ampliando a rede de pessoas que podem ser chamadas a ajudar em caso de necessidade. Este sistema tem a peculiaridade de não excluir as mulheres da liderança familiar, como é o caso da família patriarcal, nem os homens, como acontece com a família matrifocal, já que qualquer homem ou mulher iniciados dentro do culto têm a possibilidade aberta de tornar-se chefe de urna família-de-santo (Segato,2000, p. 36).

O risco dessa abordagem é a reificação da noção de família. A partir daí, ao não destacar a conotação política de família, a teoria sobre a família de santo tomaria uma explicação meramente teológica. Uma chave para esse tipo de pressuposto pode ser encontrada, por exemplo, em Roger Bastide (1958, p.280), quando o autor afirma que na África os orixás são transmitidos, prioritariamente, via linhagens masculinas - e outras formas de estabelecimento de relação com essas divindades são possíveis a partir de tal sistema -, ou seja, há a possibilidade de ter duas divindades simultaneamente ou alguma margem de troca no decorrer da vida. O que Bastide explicita com isso é que com a experiência traumática da escravidão e a consequente quebra de linhagens, haveria um abandono da transmissão por meio delas, e as relações com os orixás passariam a ser efetuadas exclusivamente por outras vias. Bastide conclui que "não há, portanto, diferenças de fatos, mas apenas a predominância de certos termos de alternativas num país e de outros, no outro" (idem).

A explicação de Bastide, por um lado, pode ser alegórica do tratamento que dados oriundos de pesquisas em territórios africanos vieram a receber nas análises sobre o candomblé no Brasil. A justaposição dos contextos africano e brasileiro, implícita ou explicitamente, busca explicar a experiência brasileira pela etnografia africana. Esse ato revela uma postura derivada, por sua vez, de outras presunções, explicando o parentesco de santo nas religiões de matriz africana no Brasil do ponto de vista exclusivo de adaptações sócio-históricas. 
Por outro lado, se a formulação apresentada por Bastide aponta para a ruptura das relações de parentesco em relação aos orixás entre Brasil e África, é essa mesma formulação de Bastide que permite pensar, tal como constatou Goldman (2009, p. 109), que, se tais adaptações ocorreram, não foram como meras repostas arbitrárias a uma determinada situação ou evento histórico. Trata-se de predominâncias e alternativas que, como propõe Goldman, se pensadas na chave transformacional denotam as atualizações deste sistema:

(...) e aqui reside a novidade da contribuição de Bastide (...), na maior parte dos casos, as transformações não são arbitrárias, mas consistem na atualização de alternativas já presentes nas religiões africanas, motivadas pelas novas condições objetivas (Bastide 1971: 278-281) (...) Assim, a substituição da regra de determinação de pertença a um orixá (por meio de divinação, e não da descendência patrilateral) é uma atualização de uma alternativa já existente na África, ainda que só utilizada em poucos casos (doenças, descoberta de orixás oriundos da linhagem materna que podem ser adotados, o fato de ter sido criado no templo de uma certa divindade etc. (Bastide 1971, p. 280 apud Goldman, 2009, p. 110).

Há ainda outra passagem de Bastide que me parece sugestiva sobre esse processo de substituição de regras de determinação de pertença pela divinação e não pela descendência patrilateral, ou seja, a indicação de que a determinação do orixá poderia se dar por mais de um modo. Entendido enquanto fluxo, considero que sua configuração histórica não nos permite cristalizar tais alternativas como uma forma acabada, mas como um movimento contínuo de criação e diferenciação:

Da mesma forma, a religião africana tendeu a reconstituir no novo habitat a comunidade aldeã à qual estava ligada e, como não o conseguiu, lançou mão de outros meios; secretou, de algum modo, como um animal vivo, sua própria concha; suscitou grupos originais, ao mesmo tempo semelhantes e todavia diversos dos agrupamentos africanos. $O$ espírito não pode viver fora da matéria e, se essa lhe falta, ele faz uma nova (Bastide, 1971, p. 32. Meu grifo).

Há nessa formulação uma rotação de perspectiva em relação ao processo "adaptativo" desses coletivos. Uma "adaptação" como sinal de sua vitalidade e resistência a condições de extrema violência e adversidade, e não mera influência de pressões externas aos primeiros. Essa capacidade não está localizada apenas no passado, mas, como veremos, trata-se de um impulso constante de criação desses coletivos que se atualiza no cotidiano dos terreiros.

Como se percebe nesse breve panorama, os estudos sobre família de santo operam uma série de reduções da noção de "família" a partir de determinados pressupostos. Acabam por dizer menos sobre como as pessoas elaboram suas relações de santo e mais sobre as imagens antropológicas construídas sobre elas. Ao buscar uma reflexão sobre parentesco de santo em Recife, tomo o cuidado de não reificar (nem generalizar) pressupostos teóricos sobre a família 
de santo que as vejam como modelo de organização ou de grupo social, e evito reduzir suas especificidades às explicações "externalistas", que recorrem à sociedade ou a conjecturas históricas sobre sua formação.

Foram apenas trabalhos recentes sobre o candomblé que formularam novas questões etnográficas sobre a família de santo. Ainda que o objetivo deles não fosse tecer formulações estritamente sobre o parentesco das famílias de santo, eles são fundamentais para esta tese. Em primeiro lugar, o trabalho de autoria de Arnaud Halloy (2005) trata exatamente da mesma família da qual trabalhei, os Felipe da Costa, descendentes de Pai Adão no culto nagô do Recife, e a tese de doutorado de Clara Flaksman (2014), por sua vez, em sua etnografia dialoga com os principais debates tecidos na etnologia afro-brasileira em relação à experiência análoga da composição de uma família de "sangue" e de "santo" no candomblé baiano.

Arnaud Halloy (2005) propôs um sistema em que coexistem duas formas de transmissão do saber, ou seja, duas formas de aprendizado: a "consanguínea", descrita por ele como "modelo biológico", e a transmissão por "participação", descrita como "modelo culturalista". Esses modos distintos de conhecimento seriam, na sua visão, "complementares" entre as duas formas de aprendizado. O primeiro modelo seria restrito à família de Pai Adão (o fundador do terreiro) e seus descendentes diretos, e o segundo seria adquirido pelos outros integrantes do terreiro sem vínculo consanguíneo com a família. Embora reconheça a existência de uma distinção dessa ordem, não a entendo como modelos distintos que operariam por complementaridade, tal como espero demonstrar ao descrever a relação de "herança espiritual" no quarto capítulo desta tese. Outra ressalva que faço é que esse modelo de transmissão não é de modo algum restrito aos descendentes de Pai Adão; pelo contrário, quase que a totalidade de pessoas com as quais convivi em meu campo elaboraram suas experiências religiosas a partir das noções de "sangue" e "descendência".

Clara Flaksman (2014) faz sua pesquisa em terreiros de Salvador, especialmente o Gantois, terreiro que compartilha a experiência de ser dirigido por pessoas de dentro de uma mesma "família consanguínea". Flaksman, que se concentra em torno da noção de "enredo" no candomblé - noção que, de algum modo, toca diretamente nas relações de parentesco, como a autora mesmo o diz:

O argumento central aqui contido é de que o uso muito frequente do termo 'enredo' é reflexo de um modo de existência múltiplo, um modelo de relacionamento intrinsecamente ligado ao candomblé. A escolha do termo se deve justamente à sua pluralidade de significados, dentre os quais me detenho em três que considero especialmente representativos desse modelo: enredo enquanto narrativa, enquanto modo de relação e como sinônimo de emaranhamento. Ter enredo é ter uma relação; ou melhor, um complexo de relações. A utilização mais frequente do termo diz 
respeito aos laços familiares, que por sua vez também podem ser múltiplos e diversos. Ou seja, quando alguém me dizia que eu tinha enredo, estava querendo dizer, em última instância, que eu tinha uma relação familiar, ancestral — fosse direta ou indireta - com algum orixá; e seria então pela vontade deste que eu estaria ali naquele momento. Essa relação pode se dar de inúmeras maneiras e em diferentes planos pois um enredo pode dizer respeito tanto a relações entre orixás quanto a relações entre seres humanos e ainda, muito frequentemente, entre humanos e orixás. Essas relações acontecem em planos de existência diversos - o que, no caso dos orixás, tanto tem a ver com os orixás 'gerais', as entidades propriamente ditas, quanto com os orixás 'individuais', que devem sua existência, salvo raras exceções, à feitura de algum filho ou filha de santo (Flaksman, 2014, p.7).

Dito de outro modo, para a autora, o conceito de "enredo" descreveria múltiplas relações nas quais, em suas palavras, a transmissão pelo "sangue" teria um papel fundamental para os praticantes do candomblé: "pois ter enredo é ser um pouco aquilo com que se relaciona, participar da natureza do outro, ter correndo nas veias tanto o sangue quanto as relações e as histórias que compõem a pessoa no candomblé” (Idem, 133).

Tal argumentação permite que eu apresente como percebo a relação entre sangue e santo. Em vez de construir uma equivalência entre o que as pessoas entendem como descendência ao traçar suas genealogias e os argumentos estrutural-funcionalista sobre "descendência", por exemplo, Flaksman apoia-se em outra imagem para entender tal relação, trazendo para sua argumentação a descrição de Ordep Serra (1978) sobre a noção de "axé”, força presente e atuante por meio de orixás, ancestrais, espíritos e outros seres do candomblé. "Iniciar-se", nessa perspectiva, "equivale a filiar-se a esses ancestrais - e no caso não importa a genealogia 'real' do sujeito" (Serra, 1978, p. 37). Embora a diferenciação entre a genealogia de santo e a consanguínea implique na presunção de que o sangue seja mais "real", para usar um termo do autor, o axé permite estabelecer uma conexão entre os filhos de santo e seus orixás, o que Flaksman define como "parentesco ontogenético".

Com o modelo da família de santo extensiva à família de sangue, criou-se um modelo de parentesco ontogenético, onde o santo — ou, em última instância, o axé — se transmite pelo sangue, e onde as descendências (de sangue e de santo) seguem alguns padrões que iremos examinar a seguir. Verifica-se uma preocupação constante com a reconstrução desses laços de parentesco, marcada principalmente pela busca de uma linhagem que seja concomitante, tanto de santo quanto de sangue (Flaksman, 2014, p.127).

Não é possível encontrar nas etnografias sobre o candomblé um modelo abrangente que dê conta das diferentes composições das relações entre o parentesco de sangue e de santo. Logo, não proponho um inventário geral das diversas manifestações dessa relação. O caráter comparativo dessa questão, nesse caso, apontaria não para o caráter geral dessa relação, e sim 
para suas particularidades. Antes de advogar a prevalência de um ou outro modo de relação, a saber, aquele que proíbe a iniciação de santo pelo genitor consanguíneo, ou aquele que afirma não haver ninguém melhor que uma mãe ou pai de "sangue" para fazer seus "filhos" no santo, interessa-me apontar a importância dessa relação para os praticantes do candomblé, seja quando a negam ou afirmam. Dito de outro modo, eu tomo como referência os exemplos em que essa relação surge mais como uma "força", um vetor de transmissão constitutivo da relação entre pessoa e santo (e das dimensões daí derivadas), do que como uma "regra" prescritiva dos relacionamentos. No caso da minha etnografia, interessam os modos como certas disposições da família nagô são elicitadas a partir das heranças espirituais que vinculam pessoas, orixás e ancestrais.

\section{SOBRE O NAGÔ E AS NAÇÕES DE CANDOMBLÉ DO RECIFE}

Nos estudos sobre as religiões afro-brasileiras, sob o rótulo de "o xangô de Recife", encontramos descrições sobre as comunidades de terreiro que, a exemplo de seus cognatos no Brasil, seriam cultos de origem africana, com rituais de iniciação, transe mediúnico, sacrifícios de animais e que se organizariam em terreiros, liderados por pais e mães de santo, formando extensas redes de casas de santo por meio de famílias genealógicas vinculadas a nações de origem nagô, xambá e jeje.

O xangô possuiria uma característica própria em suas casas: a divisão espacial interna entre o local ritual destinado aos objetos e assentamentos dos orixás (o peji) e um quarto destinado aos eguns, ou ancestrais (o balé). Além dessa divisão, encontra-se ainda um espaço destinado ao culto da jurema, modalidade religiosa que cultua caboclos e índios, mestres e mestras. Cada espaço é cuidadosamente separado dos demais e seus ciclos de rituais devem ser alternados. É preciso esperar todo o tempo ritual das obrigações: oferendas de comidas e animais, preparo destes, e o tempo de repouso das oferendas nos assentamentos até serem despachados no mato ou nos rios para que outro território ritual seja acessado.

Escolhi usar o termo nagô, ou candomblé nagô, em vez de "xangô" pernambucano, por ser o nome pelo qual as pessoas do nagô o denominam. "xangô" seria o "nome de branco", que pessoas não pertencentes ao candomblé utilizavam para se referir a ele, sendo censurado fortemente pelas pessoas com as quais convivi em Recife. É importante notar que o termo "nação" raramente aparece no vocabulário das pessoas para se referirem à sua tradição. O termo aparece em outros dois contextos: na definição de um Maracatu ao qual se pertence - "essa é a 
minha nação" - e para falar das outras modalidades de candomblé - "você é nação [em relação ao ketu]".

O termo nagô no Brasil é amplamente difundido como sinônimo dos povos iorubás da Nigéria (Bastide, 1958; Verger, 1993; Lima, 1977; Carvalho, 1984; Santos, 2002; entre outros). Os estudos afro-brasileiros tendem a situar as nações do candomblé em "continuidade" com diversos grupos étnicos africanos, a exemplo dessa passagem de Bastide:

\begin{abstract}
Os candomblés pertencem a 'nações' diversas e perpetuam, portanto, tradições diferentes: angola, congo, jeje (isto é, euê), nagô (ter com que os franceses designavam todos os negros de fala iorubá, da Costa dos Escravos), queto, ijexá. É possível distinguir essas 'nações' irmãs das outras pela maneira de tocar tambor (seja com a mão, seja com varetas), pela música, pelo idioma dos cânticos, pelas vestes litúrgicas, algumas vezes pelos nomes das divindades, e enfim por certos traços rituais (BASTIDE, 2001, p. 29).
\end{abstract}

Nesse sentido, um terreiro "jeje" seria uma designação de um terreiro oriundo de um grupo étnico ewe-fon, ou da nação "ketu" e "nagô", ambas sendo iorubá, quase que como sinônimos de uma mesma nação. A terminologia, nesse caso, diria mais sobre uma diferença regional de nominação, a exemplo dos candomblés em Recife serem nomeados como xangô e na Bahia e alhures como candomblé. Essa explicação tem sido aceita de maneira inconteste por diversos estudiosos dos candomblés, mas parece-me haver um difusionismo de fundo nessa explicação, ou seja, no início, era o mesmo grupo de pessoas, que com a escravidão foram sequestradas e se concentraram em determinadas regiões do Brasil, e que com o passar dos anos, foram se dispersando e se diferenciando a ponto de se constituírem como realidades distintas, embora continuassem com uma mesma origem.

Essa interpretação é difundida sem maiores problematizações, quase que como um dado autoevidente. Contudo, ela me parece insatisfatória com o que me explicavam meus anfitriões em Recife. Evidentemente não estou refutando a ligação desses terreiros com esses povos originários africanos, mas essa vinculação não pode ser feita apenas em termos de sua origem, devemos respeitar, sobretudo, como algo de seu presente. Uma explicação que se situe ao lado de outras elaborações históricas. Talvez seja a hora de rever nossas teorias sobre essas diferenças entre as nações do candomblé, nosso modo genealógico de explicação. Nossas concepções de "grupos étnicos" ou de "identidade étnica" oferecem uma abordagem muito aquém do tipo de elaboração desses coletivos. As nações do candomblé nos colocam uma questão para repensarmos como conceituamos sua existência.

Em um ensaio profundo, Ordep Serra (1995) chama atenção para esse problema, a partir da "teoria da milonga", uma ação criativa dos terreiros acerca de suas origens. O ensaio, 
intitulado como "jeje-nagô e companhia", traz uma crítica contundente à associação feita por outros pesquisadores entre o que os terreiros reivindicam como nação e a noção antropológica de grupos étnicos, sobretudo em sua dimensão política:

\begin{abstract}
Por certo ninguém, no Brasil, nasce jeje, ou congo, ou ijexá etc.; mas dizer que se integra tal comunidade de culto por afiliação voluntária é contrariar a ideologia desses grupos. O povo-de-santo afirma que " ninguém entra no candomblé por querer", e "quem faz santo, faz por necessidade ... ". o imperativo da aflição que leva a pessoa a iniciar-se é visto como sintoma de uma dívida para com os orixás, a qual impõe a ligação com um axé; e ligar-se a um axé é filiar-se a uma " nação". Entende-se que ao fazê-lo cumpre-se um destino: cada um entra, pois, para a "nação" que lhe cabe, por deliberação de Deus e dos "santos" (Serra, 1995, p. 107).
\end{abstract}

As nações, enquanto reinvindicação do povo de santo, possuem a capacidade de gerar suas próprias similaridades e oposições com base nas analogias estabelecidas pelos praticantes do candomblé em Recife. Os terreiros e, por conseguinte as nações, estão em comunicação uns com os outros, de modo que alguns terreiros comportam mais de uma nação. Assim, se tomarmos a nação como medida de relações, depreende-se que essa medida é uma replicação do modo de se relacionar com diferentes domínios religiosos dentro de uma mesma casa de candomblé. E, conforme pretendo mostrar, essa medida de relação aponta para uma questão fundamental nesses terreiros: ainda que exista comunicação entre os domínios, ela não incide na tentativa de englobar um domínio sobre o outro, nem uma nação pela outra.

Atualmente em Recife ${ }^{14}$, as principais nações do candomblé são: a nação nagô, a nação xambá e, em maior número de terreiros, a nação jeje. Podemos pensar a relação entre essas nações como diferentes camadas de sedimentação histórica entre constantes trocas e diferentes participações rituais, seja pelo relacionamento religioso entre seus membros, ou pela interação entre casamentos e laços consanguíneos de seus participantes. As casas nagôs, como veremos, possuem uma maior duração histórica em termos de antigas casas em funcionamento da cidade.

A nação xambá, embora de chegada posterior às casas nagô, é igualmente antiga em termos de longevidade de casas em funcionamento, suas primeiras casas, oriundas do início do século passado, não existem mais. Essas duas nações conformaram o que se convencionou denominar como o "xangô do Recife", em termos de suas características rituais, estilo de danças

\footnotetext{
${ }^{14}$ De acordo com o "Estudo da Pesquisa Socioeconômica e Cultural de Povos e Comunidades Tradicionais de Terreiros" (2011), que abrangeu 1.261 terreiros da Região Metropolitana do Recife, a vertente religiosa mais numerosa é a Jurema, com 896 casas, em seguida vem a denominação dos terreiros de candomblé, 703 casas, seguidos pela Umbanda, 365 casas, o Nagô, com 181 casas, e, por fim, se denominam como Xangô 10 casas. O estudo aponta ainda que mais da metade das lideranças dos terreiros afirmou mais de uma vertente religiosa em suas casas, como nagô e Jurema, candomblé e Jurema. O estudo constatou ainda a convivência de múltiplas denominações religiosas no espaço de um mesmo terreiro (BRASIL, Alimento sagrado, 2011, p.139).
} 
e roupas, conjunto de instrumentos percussivos: os ilus, principais orixás cultuados e calendário de festividades. Compartilham ainda um repertório comum de alguns cânticos rituais, devido à intensa troca ritual entre essas nações em meados do século passado. Entretanto, se em um nível é possível encontrar grandes semelhanças e proximidades entre essas nações, as importantes diferenças entre elas são frequentemente mobilizadas por seus praticantes, em uma infinidade de detalhes rituais. Atualmente, a principal casa da nação xambá é o Ilê Axé Oyá Meguêê ${ }^{15}$ em Recife.

Outra importante nação a compor o universo do candomblé de Recife e Olinda é a nação jeje. Sobre essa denominação, há uma diferenciação importante colocada pelas pessoas com quem convivi. Segundo me contaram, em Recife havia ao menos uma grande casa jeje, que era contemporânea ao surgimento do Sítio, denominada "Seita Africana São Jeronimo", na rua da Mangabeira, liderada por uma família africana de sobrenome Almeida. Esses sacerdotes são citados em Bastide e Verger (2002), em um trabalho sobre adivinhação no Brasil, no qual reconhecem a existência de muitos babalaôs em Recife:

Em Recife também houve babalôs famosos: Vicente Braga, vulgo Atere Kanyi; seu filho Joaquim, vulgo Aro Moxégbileman; Cassiano da Costa, vulgo Adulendju; João de Almeida, vulgo Gogosara; seu filho Claudio vulgo Bamboxê ou Oya-di-pe (Bastide e Verger, 2002, p.194, meus grifos).

Ainda na época de Adão, segundo Pai Paulo, havia outro africano que jogava Ifá: "Claudino Gomes de Almeida Bamboxê, e não Claudio como diz no livro, era da nação jeje, jeje-mahi. Pai de Eustáquio e avô de Jeronimo. Eles eram muito próximos, costumavam se visitar e comparar o resultado do jogo. Um confirmava o que o outro falava".

No trabalho de Gonçalves Fernandes, aparecem várias referências a Claudino Bangbose e um depoimento do mesmo:

\footnotetext{
Sobre a Seita Africana São Jeronymo declaro que conheço a seita africana desde 1901, em casa dos-meus pais, que eram filhos legitimos de preto da costa, da nacão gêgi, vindo eu a ser neto. Lembro-me muito bem que existia em Recife grande quantidade, sendo sua maioria do sexo femenino e algumas tinham compartimento no mercado e outras - vendiam nos pés de escadas e moravam, -a maior parte, em São José, nas ruas da Detenção, Santa Rita, Nogueira, do Peixoto. Eram muito unidos e quando em dia das obrigações se reuniam em casa dos meus pais em três partes nagô, gêgi e alufa (Fernandes, 1937, pp. 98-99).
}

Essa fala, a exemplo da de Pai Paulo, aponta para a relação entre diferentes nações do candomblé desde a formação das primeiras casas em Recife. A reunião entre diferentes nações

\footnotetext{
${ }^{15}$ Sobre esse terreiro, conferir os trabalhos de Costa (2009), Kubrusly (2018), Rosa (2005, 2009).
} 
nas obrigações permitiu, como ainda permite, o trânsito entre diferentes técnicas rituais ao longo da história do nagô. A casa da família Almeida não perdurou após a morte do último pai de santo, o último sacerdote foi Jeronimo Almeida, Ifabaila, no final dos anos 70. Seu pai, Estáquio, fora um importante sacerdote entres os anos de 30 e 50. Há em Recife pessoas que descendem dessa rama, mas se denominam hoje como nagô. Isso alude para as passagens entre uma nação e outra naquele período.

Hoje, o jeje em Recife é derivado da casa de Seu Raminho de Oxóssi, Severino Martiniano da Silva, sacerdote da Roça Osùn Oparà Oxossi Ybualama. Raminho fora iniciado no nagô na antiga Casa do Pátio do Terço ${ }^{16}$ e, após a morte de seus iniciadores, teria mudado sua nação ao ser iniciado para Oxóssi por Zezinho da Boa Viagem, no Rio de janeiro, da tradição jeje-mahin, tradição com raízes na cidade de Cachoeira na Bahia. Raminho é um dos mais importantes sacerdotes de Pernambuco, com inúmeros filhos de santo. Essa trajetória permite a Raminho, oficiar obrigações em diferentes nações, tendo como filhos de santo sacerdotes de importantes casas do nagô e da xambá.

Foi Raminho que trouxe a Recife o estilo de candomblé dessa nação, com uso de atabaques tocados com aguidavis (varetas de madeira), conjunto de rituais e cânticos, roupas e contas no estilo do candomblé baiano. É interessante notar que, em Recife, as nações do candomblé de origem baiana, como ketu, são agrupadas enquanto jeje, o que perspectiva das pessoas do nagô as diferencia como outra nação.

O termo nação é mobilizado para se referir a essas tradições, não importando se compartilham um mesmo idioma religioso, no caso o ioruba, ou mesmo a designação "nagô", que na Bahia e em outras regiões é usado como sinônimo da nação ketu. Entendo que as "nações" do candomblé operariam uma série de "transformações" nessas aparentes equivalências. Podemos aprender mais sobre essas "transformações" com os relatos de meus anfitriões de como as nações definem um modo de ação sobre o mundo, um modo de viver que precipita uma noção de origem expressa pelo conceito de herança. Como veremos, essa herança dos antepassados, uma espécie de africanidade irredutível, é transformada em diferentes momentos de acordo com os contextos, como, por exemplo, o reconhecimento ou a atribuição de parentesco mediante determinados traços físicos ou raciais, ou ainda um modo de dançar, uma invocação ou toada, idiossincrasias da família Felipe da Costa e da rede de casas de candomblé que a compõe.

\footnotetext{
${ }^{16}$ Retomo em detalhes nos capitulo subsequentes a história dessa casa.
} 
A rama do Sítio de Pai Adão, e em especial a família Felipe da Costa, provavelmente é um dos casos mais longínquos e efetivos de interlocução antropológica de maior intimidade e duração, abrangendo, diretamente, três gerações de antropólogos: José Jorge de Carvalho e Rita Segato, nos anos 70, Arnaud Halloy, no início dos anos 2000 e, agora, minha pesquisa. Sem contar o auxílio indireto que prestaram à maioria dos estudiosos do "xangô pernambucano" em diferentes gerações (Fernandes, 1936; Ribeiro, 1958; Motta,1988; Pereira,1994; entre outros). De todo modo, era comum a referência a situações de campo vivenciadas por eles com outros pesquisadores. Essas situações, por sua vez, serviam como guia de "boas maneiras" imputadas aos primeiros momentos de nossa relação.

A respeito desses três primeiros autores, nos quais meu trabalho se inspira, apresento uma breve síntese. A análise e o diálogo com suas considerações e dados etnográficos serão feitos no decorrer deste trabalho.

O principal trabalho sobre o nagô de Recife foi realizado por José Jorge de Carvalho (1984), cujo principal tema é a complexa relação entre música e ritual. Trata-se de uma etnografia de grande alcance, atenta aos mínimos detalhes da ação ritual, bem como para as formulações e elaborações das pessoas de sua época sobre seus significados. Para compreender o modo de interação entre música e ritual, dispôs da gravação e, posteriormente, tradução de todo o repertório dos cânticos do nagô. Essa impressionante tese de doutorado em Etnomusicologia, defendida na Universidade de Belfast, continua como um dos mais importantes trabalhos sobre os cultos afro-brasileiros, e suas considerações a respeito do modo de vida das pessoas continuam, em muitos aspectos, atuais. Ao longo da tese, farei muitas referências ao seu trabalho.

O trabalho de Rita Segato (1984) é um tratado e, talvez, a primeira tentativa de elaborar, em bases etnográficas, a partir da noção de construção da "pessoa afro-brasileira", uma teoria sobre o gênero e sexualidade do candomblé, dimensão ainda hoje pouco explorada em nossos trabalhos. Essa noção de pessoa é o ponto de partida de sua discussão e exegese sobre o modo como as pessoas do xangô elaboram um discurso alternativo sobre o "gênero", "sexualidade" e "família". Rita Segato correlaciona, por exemplo, os enunciados sobre homossexualidade masculina e feminina com os mitos dos orixás, defendendo que a vida dos homens reflete a vida dos orixás. Outra importante conexão entre esses diferentes registros foi seu olhar para a questão do parentesco nos candomblés em Recife, da qual o discurso sobre a família ganha relevo quando contrastado com as teorias sociais sobre família brasileira e patriarcado. 
Outro trabalho com grande imersão no cotidiano da família, mas na geração subsequente a José Jorge de Carvalho e Rita Segato, foi a tese de Arnaud Halloy (2005). Sua tese também se concentra na etnografia dos rituais do xangô e nas interações cotidianas de seus praticantes. O principal interesse do autor é a mediação da vida das pessoas com as divindades, propiciada pela característica intensidade ritual do nagô e permeada por relações bastante "íntimas" entre os orixás e seus filhos. Halloy dá especial atenção ao papel ritual da transmissão religiosa.

O tema de minha tese se inspira, portanto, nas etnografias elaboradas por esses trabalhos que exploraram detalhadamente, e a partir de um longo trabalho de campo, aspectos fundamentais do universo nagô e da família Felipe da Costa. Em certo sentido, pretendo dar continuidade e complementar o tratamento de tais aspectos, evidenciando dimensões que, por vezes, ficaram subsumidas. A oportunidade dessa sequência de trabalhos na qual o meu se insere oferece, ainda, uma visada histórica dessa família e do candomblé nagô do Recife. Essa visada histórica, por sua vez, não é somente da antropologia sobre a família, mas também, à sua própria maneira, da família sobre a antropologia, conforme percebi em meu trabalho de campo.

\section{TRABALHO DE CAMPO}

As considerações e argumentos que embasam esta tese são fruto da minha convivência diária com meus anfitriões em Recife, em especial no Ilê Iemanjá Ogunté, em Água Fria. O trabalho de campo ocorreu entre os anos de 2013 a 2018, dos quais, em período continuo, foram 8 meses entre os anos de 2013 a 2014, como parte da pesquisa de Mestrado em Antropologia, desenvolvida no Programa de Pós-Graduação em Antropologia da Universidade de São Paulo (PPGAS-USP), e 15 meses entre os anos de 2016 e 2018. Nos demais anos, passei ao menos 3 meses em Recife, invariavelmente entre dezembro a março. Totalizando ao menos 32 meses de pesquisa de campo.

\section{O BAIRRO E OS TERREIROS}

Morei próximo à casa de Mãe Lu, no mesmo bairro de Água Fria, em uma rua de simpático nome Bom Conselho. O bairro se estende pela região da Avenida Beberibe, seguindo os bairros do Fundão, Cajueiro, Linha do Tiro, Dois Unidos e Beberibe, até o Rio Beberibe. Os bairros também possuem seus “Altos”, como são chamados os morros, “Alto Santa Terezinha”, “Alto José Bonifácio", ”Bomba do Hemetério", entre outros, e segue até o limite do município 
do Recife com a região limítrofe de Olinda, quando encontra o bairro de Caixa D’Água. Essa região era conhecida como "Beberibe de Baixo" e iniciou seu processo de urbanização com a vinda da população negra que ali fazia seus mocambos, pequenas casas de taipa e palafitas nas beiras de rios e riachos, e, em momento posterior, pelos migrantes da Zona da Mata e Agreste.

O processo de ocupação dessa área se deu pela expulsão dos africanos e seus descendentes das regiões centrais da cidade do Recife nos processos de "modernização" da cidade. Com a vinda de um considerável contingente populacional, veio também a linha férrea onde funcionava um trem movido a combustível, chamado de "maxabomba", que impulsionou o loteamento dessa área. Ainda hoje essa é a região com o maior número de pretos e pardos da cidade de acordo com o IBGE ${ }^{17}$.

Essa região ainda não despertou os desejos nefastos das grandes construtoras. Os grandes prédios que se avolumam no horizonte do bairro não atravessam o canal do Arruda, que, com a Avenida Norte, segue como uma barreira do bairro contra esses empreendimentos em série, grandes prédios similares a um comprido box de banheiro e que têm se multiplicado pela cidade de Recife, característicos de bairros de classe média e classe média alta, como Boa Viagem e adjacências, mas que tem se imposto no residencial subúrbio. Por enquanto, essa região permanece ilhada e, em seus bairros, prevalecem ainda as casas populares, pequenos prédios e vilas, muitas delas ainda com a estrutura da década de 40 e 50 . Em uma das principais ruas do bairro, foram erguidos pequenos conjuntos habitacionais, cujos moradores foram transferidos das regiões de palafitas e favelas ${ }^{18}$. Uma dessas favelas ficava no terreno ao lado do Sitio de Pai Adão. Alguns filhos de santo do terreiro moram nesses conjuntos, chamados de "prédinhos".

\footnotetext{
${ }^{17}$ Segundo dados do IBGE, de acordo com o último censo, de 2010, o bairro de Água Fria possui a maioria de sua população negra (pretos e pardos), 72,41\%. Outros dados notáveis são a taxa de proporção de mulheres chefiando domicílios, de 47,03\%, e o Valor do Rendimento Nominal Médio Mensal dos Domicílios, que é de R\$1.189,92. Em comparação com dados gerais da cidade, o índice da população negra é de $57,91 \%$.

${ }^{18}$ De acordo com o estudo da Pesquisa Socioeconômica e Cultural de Povos e Comunidades Tradicionais de Terreiros (2011), que abrangeu 1.261 terreiros da Região Metropolitana do Recife e que permanece como um dos registros mais atuais em amplitude de dados referentes às características socioeconômicas dessas casas religiosas. Segundo esse estudo, os terreiros da RM de Recife possuem os menores terrenos em comparação às outras regiões pesquisadas: $82,7 \%$ das casas têm área abaixo de $300 \mathrm{~m}^{2}$. Com relação ao tamanho dessas casas, ou seja, da área construída na qual as atividades religiosas se desenvolvem, constatou-se que $25,8 \%$ têm até $50 \mathrm{~m}^{2} ; 30 \%$, entre 51 e $100 \mathrm{~m}^{2} ; 22,3 \%$, entre 101 e $200 \mathrm{~m}^{2}$, e $21,8 \%$, acima de $200 \mathrm{~m}^{2}$. Quanto ao acesso dos terreiros às fontes de água, observam-se ainda desigualdades regionais. Se, na RM de Recife, o percentual dos terreiros com atendimento irregular da rede de água é de 67,7\%, na RM de Porto Alegre, esses casos não chegam a 1\%. A RM de Recife é a que apresenta os maiores percentuais de fossas rudimentares e sépticas não ligadas à rede coleta: $17,5 \%$ e $23,4 \%$, respectivamente. É nessa região metropolitana onde os terreiros mais frequentemente reportam o despejo do esgoto em valas: $7,5 \%$.
} 
O bairro e sua vizinhança concentram um grande número grupos culturais e blocos carnavalescos, como: Maracatus, Escolas de Samba, Caboclinhos, grupos de Samba-Reggae, Bois, Ursos, Blocos de Pau e Corda, Troças Carnavalescas, entre outros.

O Bairro de Água Fria possui uma das maiores concentrações de terreiros do Recife. A região por onde o bairro se estende, desde o final do século XIX, era denominada, pejorativamente, como "catimbolândia", e as principais casas de candomblé do século passado nasceram nessa região. Na Rua da Regeneração, funcionavam dois grandes importantes terreiros, a Casa de Artur Rosendo, primeiro pai de santo da nação xambá a se estabelecer na cidade, em 1923, e a casa de Mãe Lidia Alves, Orixala Talabi, ambas desativadas atualmente. Dessas grandes casas, a única a permanecer em funcionamento no mesmo local é o Sítio de Pai Adão.

Um dos pontos vitais do bairro é o Mercado de Água Fria: um grande galpão em estilo modernista, parecido com um hangar, construído em meados dos anos 50, que abriga pequenos comerciantes, açougues, sapateiros e alfaiates. Uma das mais importantes lojas é a de Vavá, especializada em artigos religiosos e localizada bem na entrada do mercado. Vavá fornece os principais produtos utilizados pelos terreiros, como velas, azeite de dendê, pimenta, ervas, alguidares de barro e imagens de santo. Até pouco tempo, era a única loja a fornecer esses produtos na região. Hoje enfrenta a concorrência de uma pequena banca na Feira Nova de Água Fria, comandada por uma evangélica, chamada de "Irmã". Certa vez ouvi essa senhora oferecer produtos mais em conta do que Vavá, para quem o bem-humorado freguês respondeu: "Não sabia que Jesus também comia azeite irmã! ".

Em frente ao Mercado se estendia uma feira livre, que funcionava praticamente por 24 horas. No meio-fio da via, acumulavam-se, em meio à água escura e viscosa de odor fétido, cascas de frutas e verduras, sacolas plásticas, copos descartáveis, restos de marmitas, e guimbas de cigarro, que vão ficando para trás no ir e vir dos transeuntes. Pessoas, motos e bicicletas dividiam o espaço. Durante os anos em que realizei minha pesquisa, o governo municipal implementou um projeto de "revitalização" nos mercados públicos, alegando melhorias nos entornos dessas construções, e retirou os comerciantes e suas barracas que bloqueavam a vista das antigas fachadas. Em Água Fria, esses comerciantes foram realocados em um antigo galpão que outrora funcionara como um cinema. Nem todos conseguiram o espaço para colocar suas bancas de frutas e alimentos. Poucos, ainda, foram os que conseguiram realocar seus bares e restaurantes populares nesse espaço. Um dos objetivos era “devolver” a circulação das calçadas aos pedestres e carros e, principalmente, atrair o consumo da classe média. 
A maioria dos pequenos comerciantes, que há anos se estabeleceram nesses locais, foi removida. Eram pequenos fiteiros ${ }^{19}$ e bares, os conhecidos come em pé. Esse comércio se estendia até altas horas da madrugada e garantia nesses locais um fluxo constante de pessoas, seu funcionamento tinha como efeito a diminuição de roubos e furtos que aconteciam nas paradas de ônibus desses locais. Atualmente, as ruas do entorno do Mercado estão vazias, e o medo de ser furtado ou assaltado, depois que o Mercado se fecha, faz com que os moradores evitem ao máximo andar por suas imediações após às 19 horas. A região do entorno continua bastante deteriorada, com o acréscimo da sensação de insegurança que agora aflige os frequentadores do Mercado.

Nas vielas circundantes, proliferam pequenas vendas, peixarias, quitandas e mercadinhos que abastecem os terreiros com os itens utilizados nas obrigações e oferendas. Trabalham nessas imediações um grande número de homens negros, alguns sexagenários, que transportam as compras e feiras dos consumidores em pesados carrinhos de mão, fazendo o frete pelo bairro a preços baixíssimos, não ultrapassando 10 reais.

Seguindo pelo Mercado de Água Fria, o caminho que leva ao terreiro é a Avenida Beberibe, e, à direita, uma pequena rua que dá para o muro de fundo do Sítio. Antigamente toda essa extensão de terra pertencia ao Sítio, que se estendia da estrada Velha de Água-fria até a Avenida Beberibe. No início dos anos 50, devido a problemas com impostos, o terreno foi loteado em algumas partes, perdendo o tamanho original. Atualmente, a própria casa do Ilê Iemanjá Ogunté enfrenta problemas de impostos. Uma das ações pensadas para solucionar o problema é entrar com o pedido de usucapião da casa, para então regularizar a pendência financeira, dado que as casas da rua pertenciam ao falecido proprietário e que, após sua morte e um alongado problema da partilha, o aluguel deixou de ser pago e nunca mais foi cobrado.

O Ilê Iemanjá Ogunté fica nessa rua de paralelepípedos e casas geminadas, com estilo arquitetônico comum das casas de subúrbio daquela época (talvez dos anos 50, ou 60). Construídas em par, a disposição dos cômodos é replicada: entra-se (raramente) por um pequeno hall protegido por uma tela de ferro craveado, encontra-se uma sala com entrada para os quartos (três), ao final da sala, o banheiro e a cozinha. Como é de se esperar, do projeto original só se manteve a fachada, pois os interiores das residências foram alterados e adaptados às exigências e necessidades familiares.

Tal qual as casas vizinhas, a configuração comum das famílias com quem convivi esses anos em Recife apresenta características comuns de coexistência. A presença constante de

\footnotetext{
${ }^{19}$ Pequenas barracas que vendem doces,cigarros, miudezas em geral.
} 
membros da família estendida ao núcleo residente ${ }^{20}$. Sejam os filhos consanguíneos, de adoção, "todos de coração", aos quais com muito orgulho me somei. Tal convivência nesse meio torna difícil, no início, distinguir essas sutis variações, o denominador comum é que todos são filhos de santo.

A imensa maioria das casas era liderada, ao menos economicamente, por pessoas idosas, quase sempre mulheres, que custeavam a manutenção das casas com os recursos de suas aposentadorias e acréscimos advindos de outras ocupações, como: costura, reforço escolar, venda de produtos de beleza e atividades religiosas. Os filhos e filhas contribuíam eventualmente para as despesas, mas tal contribuição era sempre incerta, dado que a maioria não possuía nenhum tipo de trabalho remunerado, tampouco dispunha de vínculos empregatícios com carteira assinada e algum direito. Alguns eram usuários de programas sociais de transferência de renda, a exemplo do Bolsa Família.

Nos últimos anos, como parte da agenda neoliberal do governo de Michel Temer ${ }^{21}$ várias dessas famílias perderam seu acesso ao benefício. São frequentes os assaltos e furtos nas imediações do terreiro. Um dos efeitos trágicos da desagregação do tecido social do bairro e vizinhança foi a retomada das mortes por crimes violentos. Entre 2017 e 2019, somente na rua foram dois casos de jovens negros que perderam a vida nessas condições.

A rede de terreiros também foi afetada por assassinatos de filhos de santo. Houve, ao menos, um homicídio de um filho de santo, um rapaz de Xangô, morto em decorrência de homofobia, uma tentativa de homicídio contra um filho de Iemanjá, e o assassinato de um policial, filho de Ogum, em uma emboscada ${ }^{22}$.

\footnotetext{
${ }^{20}$ Essa configuração familiar é muito próxima à descrita por Henry Marcelin (1996), sobre a experiência familiar dos negros de Cachoeira. Em linhas gerais, o autor propõe um modelo de interação familiar entre dois níveis conceituais: o das "casas" e o da "configuração de casas" (conjunto de casas estruturadas por uma ideologia da família e do parentesco) como um sistema de significados imersos nos contextos étnicos e sociais. Essa proposição visa a retirar a experiência da família negra (proposição da qual meu trabalha se associa) as análises que as situam como desestruturadas, relegando-as a ordens de anomia e patologia (Marcelin, 199, p. 16). Tais pressupostos são derivações de assunções da noção de família como grupo doméstico coeso, um "bias" de recortes analíticos que estabelecem as famílias em relação a "domínios" doméstico e o jurídico-político, tal qual formulado por tradições estruturais-funcionalistas, entre a "amity — domínio protegido das vicissitudes da política, das leis do mercado e das determinações históricas, lugar do exercício legítimo da sexualidade e da criação dos filhos — e a polity domínio do exercício das leis do mercado, da política e da história". A tal análise é acrescentada "uma concepção miserabilista das classes populares, traduzida em uma abordagem que faz de suas organizações familiares uma mera variável da estrutura socioeconômica e transforma esses agentes familiares em seres incapazes de produzir um mundo e habitá-lo simbolicamente" (Marcelin, 1999, p. 32).
}

${ }^{21}$ Michel Miguel Elias Temer Lulia, foi presidente de 31 de agosto de 2016, empossado após o impeachment da titular, Dilma Rousseff, a 1 de janeiro de 2019.

${ }^{22}$ Os ataques aos espaços físicos das religiões afro-brasileira, suas casas religiosas, somam-se às diversas ações contrárias a tais religiões, sendo uma extensão da perseguição racial e religiosa que elas sofrem ao longo de nossa história. Além desses, registram-se dezenas de casos de agressões aos religiosos e de ataques aos terreiros, que são 
Além desses casos, houve um aumento exponencial nos casos de agressões contra os terreiros. Na rede de terreiros da família, presenciei dois casos: um ataque com pedras em uma cerimônia de jurema, em uma casa próxima à Feira de Água Fria, no momento das obrigações. E um assalto à mão armada na casa de Pai Guara, no qual três homens invadiram a casa, no momento do toque, e fizeram um arrastão. Um dos filhos de santo, que era policial, reagiu e houve uma troca de tiros no meio do barracão, dentro qual havia, ao menos, 50 pessoas. Ninguém se feriu, mas as pessoas ficaram muito abaladas. Guara deixou de residir no terreiro e passou a morar em um apartamento, indo ao terreiro apenas para obrigações.

\section{A ROTINA E O TRABALHO DE CAMPO}

Meus anfitriões, em Recife, são bastante acostumados ao trabalho de campo dos antropólogos (ainda que desconheçam, ou estejam pouco interessados, em seus resultados), estando habituados, de longa data, à presença por vezes incômoda de pessoas estranhas ao seu convívio, que, de uma hora para outra, encontram-se no seio de sua família, acompanhando seu cotidiano e realizando (ou não) toda sorte de perguntas e questionamentos. Minha presença entre eles não se constituiu, necessariamente, como uma "novidade".

Minha rotina ali consistiu basicamente em conviver, o maior tempo possível, no ritmo da casa de Mãe Lu, o Ilê Iemanjá Ogunté, de acordo com os acontecimentos diários e atividades rituais. O primeiro terreiro que frequentei foi a casa de Mãe Lu, no início do campo, pois era onde eu tinha mais liberdade para acompanhar as atividades religiosas. Mas, à medida que a

incendiados, invadidos, depredados e têm seus líderes ameaçados ou expulsos de suas casas e bairros por grupos de traficantes autodenominados evangélicos. Em resposta a esse cenário, por meio da mobilização de movimentos sociais e ações governamentais, foram criadas ações institucionais, como o "Disque 100", em 2011, pelo antigo Ministério dos Direitos Humanos (atualmente Ministério da Mulher, da Família e Direitos Humanos) e o Dia Nacional de Combate à Intolerância Religiosa (21 de janeiro), por meio da Lei no 11.635 , de 27 de dezembro de 2007, sancionada pelo presidente Luiz Inácio Lula da Silva. Os dados do balanço do "Disque 100" relativos às notificações de discriminação religiosa configuram um total de 3.216 casos notificados desde sua criação. Em relação ao estado de Pernambuco, entre 2011 e 2020, houve um total de 83 casos notificados. O agravamento dos ataques aos terreiros e aos praticantes de religiões afro-brasileiras, exemplificados pelos dados recolhidos pela SEPPIR e pelo Disque 100, confluem com os resultados das informações coletadas no estudo denominado "Alimento: Direito Sagrado - Pesquisa Socioeconômica e Cultural de Povos e Comunidades Tradicionais de Terreiros", realizado pelo Ministério do Desenvolvimento Social e Combate à Fome em 2011. Tal pesquisa foi feita em 2010, nas Regiões Metropolitanas de Belém, Belo Horizonte, Recife e Porto Alegre, especificando os grupos agentes dos casos de intolerância. Nessa pesquisa, os resultados apresentados partem de um universo de 4.045 casas ativas, das quais quase $50 \%$ das lideranças dos terreiros disseram sofrer ou ter sofrido atos de intolerância por parte de evangélicos. É possível inferir, em contraste com as informações do Disque100, que há uma subnotificação dos casos de intolerância e ataques, já que o número de registro pela Pesquisa Socioeconômica é consideravelmente superior aos casos registrados em denúncia. Para além desse cenário de violência contra os terreiros a partir de segmentos evangélicos, há outras variáveis que devem ser levadas em conta como fontes de insegurança e vulnerabilidade dessas comunidades. 
pesquisa vinha se desenvolvendo, passei a acompanhar outros terreiros. Inicialmente, eu ia de ônibus até essas casas (que quase sempre ficavam nas redondezas e bairros próximos a ÁguaFria), mas, depois, as pessoas já reservavam um lugar no carro que vinha buscá-los, para eu ir junto. Acompanhei o cotidiano, com menos intensidade, das outras casas que configuram a rede de relações dessa família, participando do calendário ritual, ou de festas de aniversários, bem como realizando visitas, para conversar, tomar um café ou beber uma cerveja.

Nos dias de obrigação (conjunto de rituais destinados aos orixás e outros seres espirituais), eu costumava chegar cedo, em geral, no horário em que dizia que elas deveriam começar. Nessas ocasiões, ficava do lado de fora dos quartos de santo. Com o tempo, quando as pessoas foram confiando mais em mim, elas me convidavam a entrar nos quartos de santo e balé e tomar parte na dinâmica ritual. É precisamente sobre isso que gostaria de me deter agora.

Durante meu campo, diversas vezes ouvi que só se pode participar de uma obrigação quem, em certa medida, já passou por ela. Note-se que passar não implica, necessariamente, em se iniciar, no sentido mais usual do termo. Ou seja, não quer dizer que uma pessoa que não passou não possa assistir ou acompanhar o que acontece durante os rituais. Muitas vezes, em Recife, as obrigações transcorriam diante dos olhos de muitas pessoas não iniciadas, tampouco pertencentes ao quadro de membros dos terreiros. Não ser iniciado não era impeditivo para se tomar parte dessas cerimônias, conforme a literatura etnográfica demonstra. Em algumas obrigações, essas cerimônias ocorriam diante dos olhos de vizinhos, amigos ou conhecidos da pessoa que patrocinava a obrigação e que não tinham nenhum vínculo mais próximo com o nagô, ou seja, não eram "adeptos" ou "religiosos".

"Ser iniciado" ou "adepto" não garantiria o direito para participar das obrigações, há participações que só são permitidas para homens, como no caso das obrigações aos eguns. Outras que somente mulheres poderiam realizar. E, ainda, aquelas nas quais as tarefas rituais deveriam ser feitas por quem tivesse um domínio "prático" dos gestuais e etapas de sua execução - em muitos terreiros, somente uma pessoa tinha "competência" para desempenhálas.

Logo no início do meu campo, Mãe Lu telefonou para Pai Paulo, para avisar que eu já estava em Recife e que "iria trabalhar com ele agora". Pai Paulo, durante essa ligação, avisoulhe que eu precisaria, antes de começar esta pesquisa, "dar uma obrigação para Ifá e no Balé” e que, somente assim, ele poderia "me passar as coisas". Mãe Lú então me avisou: "Paulo não pode dar nada pra você do que Jorge [José Jorge de Carvalho] não tivesse ganhado de meu pai 
Malaquias. Quando Jorge foi fazer sua pesquisa, ele teve de dar uma obrigação para Orumilá e outra no Balé, e que, por isso, você terá de fazer o mesmo".

Dias depois, quando Pai Paulo chegou, ele me disse que não queria fazer diferente do que seu pai fez com José Jorge de Carvalho e me perguntou: “Jorge não fez uma boa pesquisa? Para você fazer uma boa pesquisa que nem a dele, precisa passar pelo que ele passou". Disseme, ainda, Pai Paulo: "Se você não fizer isso [a obrigação], só poderá ficar olhando e não vai aprender muito, não vai poder participar tanto...”. Realizei essas obrigações ao longo dos anos de minha pesquisa, embora minha participação tenha se dado, também, por outros motivos, como veremos abaixo. Quero destacar, por ora, que, apesar de "familiar", o termo participação implica numa relação específica com o contexto dos rituais.

É preciso explicar. Sou iniciado no candomblé desde os dezesseis anos. Ao relatar um fato de minha biografia individual (ser de candomblé), não o faço para defender que tal condição me proporcionou um meio de acesso privilegiado ao campo, ou ainda por entendê-lo como um determinado método de pesquisa. Em geral, tal constatação costuma aparecer na literatura como uma espécie de "autoconsciência culpada", ou uma breve expiação dessa, sem muitos rendimentos ao longo dos trabalhos.

Muita tinta já foi gasta na etnologia afro-brasileira, para discorrer sobre o lugar de iniciados ou não iniciados dentro de estratégias de pesquisa, no universo das religiões afrobrasileiras $^{23}$. Não pretendo ignorar esse debate, mas considero que os moldes, como eles se apresentam, são, em grande parte, infrutíferos, especialmente no tipo de rendimento teórico que promovem para antropologia. Para efeito de síntese, basicamente, esse debate diz respeito ao posicionamento do pesquisador em relação ao candomblé, ou seja, instaura uma dicotomia de visões "desde dentro" e "desde fora".

Segundo os partidários de tal debate, o antropólogo-iniciado levaria uma "vantagem epistemológica" sobre um antropólogo não iniciado, ao promover uma representação "desde dentro", conforme advogou Juana Elbein dos Santos (1977). Segundo a proposta metodológica da autora, as pesquisas do "antropólogo-iniciado" teriam resultados mais confiáveis por conterem mais propriedade, dado que sua visão interna permitiria uma capacidade de representar os terreiros, etnograficamente, com maior veracidade.

Por outro lado, o efeito reativo dos que advogam a visão do "desde fora" foi a defesa do ideal de neutralidade, do distanciamento e "pensamento crítico", em que cabia ao antropólogo

\footnotetext{
${ }^{23}$ Para uma visão elaborada sobre a questão e seus desdobramentos na produção etnográfica, ver “O Antropólogo e sua magia" (Silva, 2000).
} 
o domínio do sentido que daria ao discurso/realidade do nativo. Para isso, é necessário que se tenha um distanciamento entre o sujeito pesquisador e o objeto pesquisado. $\mathrm{O}$ discurso do pesquisador - sob pena de morte - jamais deveria ser o do pesquisado, somente assim poder-seia ser "reflexivo". Seria preciso, então, que, como pesquisadores, não deixássemos que nossas subjetividades se confundissem com as daqueles que estudamos, evitando sermos devorados pelos nossos objetos. Ao ser "de fora", os antropólogos "não iniciados" possuiriam "ingenuidade de uma criança, para dizer que o rei está nu”, o que consistiria, para alguns, na única possibilidade efetiva de se fazer uma pesquisa (Brumana, 2007).

Entretanto, a insistência dos pesquisadores nessa dicotomia "desde dentro" e "desde fora" entra em um perigoso caminho, a saber: aquele de impor uma das posições em relação à outra, em que uma seria necessariamente mais confiável e "legítima" que a outra. Como nos lembram Goldman e Lima (1999), a própria questão sobre "o que, em geral, nos aproxima e/ou distingue dos outros é inadequada e não deveria ser formulada”. Sobre o assunto, Ordep Serra diz:

Portanto, essa dicotomia tão somente "naturaliza" a oposição como uma fatalidade da lei da perspectiva de maneira tal que os opostos se acomodam e canonizam sua divergência, abençoando-se finalmente uns aos outros, com doce ironia. A visão "de dentro" e a visão "de fora" se justificam e se repelem, resumindo o debate sobre os ritos afro-brasileiros a um eterno jogo de solteiros e casados - já previamente empatado, de comum acordo (SERRA, 1995, p.7-28).

Para evitar esse caminho, procuro imaginar outra saída para essa questão, pensando a antropologia como uma atividade criativa, isto é, para usar os termos de Roy Wagner, uma atividade "mediadora". Entender a antropologia pelo termo "mediador", em certo sentido, "é uma maneira de descrevermos os outros como descreveríamos a nós mesmos" (Wagner, 2010a). A experiência é sempre mediada pelo pensamento do antropólogo, atualizando-se em campo. Daí a importância da etnografia para o autor.

A partir disso, indago-me: da perspectiva do trabalho de campo, quais seriam as implicações que surgem no fazer antropológico, dada minha condição de iniciado, que refletiriam em meus estudos sobre o candomblé?

Acredito que o caminho mais fecundo para isso é o de potencializar minha vivência dentro do candomblé, isto é, não sendo "neutralizada" enquanto crença, mas potencializando-a enquanto experiência. Acima de tudo, essa "condição" não foi utilizada, por mim, como acesso "privilegiado" ao campo, mas, sim, mobilizada tanto por mim, quanto por meus anfitriões, para perceber diferenças significativas do universo de relações do nagô em comparação ao ketu, por 
exemplo. Constantemente meus amigos em Recife elaboravam criativas comparações, que iluminaram em muito as minhas percepções sobre as significativas diferenças existentes entre as nações do candomblé.

Entendo, ainda, que evitar essa dicotomia implica, também, na recusa em assumir como "termo marcado" o rótulo de "antropólogo nativo", ou seja, implica em evitar uma dupla naturalização da ideia de "nativo", o que tornaria, ingenuamente, a categoria de "nativo" como um dado, e não como efeito da criação etnográfica, a partir do trabalho de campo. Como efeito de tal naturalização, "o aspirante a nativo só conseguiria ingressar num mundo criado por ele mesmo, como faria um esquizofrênico ou aquele apócrifo pintor chinês que, perseguido por credores, pintou um ganso na parede, montou nele e fugiu voando!” (Wagner, 2010a, p. 37).

Por fim essa é uma questão que surge no interior da antropologia enquanto disciplina, e de saída, nessa perspectiva, é uma questão de dentro. Os usos sobre a noção de "dentro" e "fora", pelos iniciados do candomblé, não diz respeito apenas ao estatuto da iniciação, ou de membros externos ou internos a uma comunidade. Ela diz respeito, também, ao tipo de engajamento ritual que uma pessoa pode aceder no interior de uma casa de candomblé, ou de um conjunto de atividades rituais. Há, portanto, diferentes graus de participação.

"Participar", em certo sentido, está relacionado ao trabalho durante as obrigações, mas não é somente isso, implica em certas disposições que a pessoa possui, como gênero, orientação sexual, orixá regente, relações de parentesco, entre outas. Pai Paulo me disse como se deu o início de sua participação nos rituais do nagô:

"Comecei a participar das obrigações acompanhando meu Pai [Malaquias] e meu tio [José Romão] por volta dos doze anos. Mas antes mesmo eu já ajudava. Teve uma obrigação para xangô, eu tinha sete anos, um galo enorme, eu segurando, aí meu pai viu que eu não ia conseguir e segurou ele mesmo. No começo, eu só machucava as folhas para os amassis ${ }^{24}$, depois comecei a responder as cantigas e cantar para os santos, tocar e dançar. Aí, fui aprendendo a segurar os bichos, como segurar, limpar os bichos e tirar o couro, os axés. Quando fiquei mais velho, meu pai sempre me esperava para começar uma obrigação, um obori ${ }^{25}$, ou para matar os bichos, enquanto ele invocava os santos e cantava para oferecer eles, fazer as invocações, essas coisas, foi assim que comecei a participar mesmo. Meu Tio Zé Romão, quando tinha quatorze anos, já ajudava Joana Batista nas obrigações que ela dava, depois de um tempo que meu Tio foi feito por dois africanos chamados Pedro Olude e Joana Batista. Meu pai foi feito por Martiniano ${ }^{26}$, meu avô não podia ser pai de santo dele, mas, com meu avô, ele aprendeu tudo o que soube. Antes

\footnotetext{
${ }^{24}$ Banho de ervas que sempre é realizado antes das obrigações.

${ }^{25}$ Obrigação em que se cultua a cabeça da pessoa no nagô, para uma discussão em maior profundidade sobre o assunto, cf: discussão Carvalho,1984; Segato, 1984; Halloy, 2005; entre outros.

${ }^{26}$ Martiniano Eliseu do Bonfim, importante sacerdote baiano falecido nos anos 40. Foi importante colaborador de três gerações de antropólogos. É considerado um dos últimos babalaôs brasileiros.
} 
de morrer, meu avô explicou para meu pai o que ele deveria fazer depois que ele morresse, os fundamentos".

No meu caso, minha participação ficou condicionada a outros fatores. Essa participação se deve, em grande medida, ao meu "trabalho" com eles. Minha participação foi resultado do intenso engajamento que meu trabalho propiciou: quanto maior era meu "trabalho", maior era a minha "participação". Nas primeiras obrigações, assumi o papel de espectador no desenrolar dos rituais, porém, aos poucos, essa observação foi se alterando. Se pudéssemos escalonar as atividades relacionadas ao "trabalho", no desenrolar dos rituais, diria que comecei no primeiro degrau, que consiste em depenar galinhas, passando, posteriormente, em retirar seus axés (órgãos dos animais específicos que são retirados, após o sacrifício, e cozidos) e cortar o eran (se refere, simultaneamente, aos animais abatidos nos rituais e à carne deles). Conforme a pessoa vai desempenhando bem essa função, ela passa aos animais de quatro patas $^{27}$, retira seu couro depois de mortos, separa o fato (vísceras) e prepara a carne, que será distribuída entre os presentes.

Além de trabalhar na cozinha, fui convocado a participar das oferendas dos animais. Como tratarei com mais detalhes posteriormente, existe uma sequência no corte dos animais para os orixás. Em geral, nas obrigações, quando se mata um cabrito ou uma cabra, acompanhase de três ou quatro galos, ou galinhas. Enquanto um ogan corta, o outro segura. Na maioria das obrigações, um ogan corta para todos os orixás e os outros vão se revezando na tarefa de segurar os animais. A exemplo de outras atividades, um iniciante começa segurando os animais menores e só depois pode segurar os animais maiores. Foi como "trabalhador" que pude participar das cerimônias descritas nesta tese.

De todo modo, como se espera ao realizar um "trabalho", eu fui incluído no grupo dos ogans, recebendo um pagamento por minha participação nas obrigações. No início, eu sempre relutava em receber minha parte na divisão do dinheiro, o que gerava um constrangimento por parte dos presentes, até que um dia, dentro do quarto de balé, Bino me falou: "Olavo, a mulher lhe deu o dinheiro já?", eu respondi que não. "Pois ela vai lhe dar, e você precisa aceitar, você está trabalhando aqui com a gente, todo mundo recebe, e você não? Não é certo isso, de agora em diante você vai aceitar o que lhe pagarem", disse Bino.

Diante do que foi dito, mas, principalmente, onde e como Bino falou, comecei a aceitar sem questionar esse pagamento, que variou de $\mathrm{R} \$ 10,00$ a $\mathrm{R}$ \$ 30,00, nas obrigações maiores. Esse pagamento era imediatamente revertido para outros ogans, ou incluído no rateio do

${ }^{27}$ São os animais maiores, como bodes, cabras, boi, porcos. 
transporte ou de bebidas após o final das obrigações. Além disso, também era pago por meio da distribuição de determinadas partes dos cabritos e porcos que me foram destinados na partilha das carnes feita pelos ogans no final das obrigações.

Esses fatos me chamaram atenção para o modo como as pessoas no nagô lidam com o dinheiro durante as obrigações. Como notou José Jorge de Carvalho, há um aspecto "não capitalista" na ideologia do xangô (Carvalho, 1984, p.371). As obrigações para os santos e demais entidades espirituais, bem como os rituais de iniciação e ritos funerários são dispendiosos e resultam, algumas vezes, em uma longa preparação financeira por parte das pessoas e comunidades para sua realização. Esse dinheiro é utilizado na compra de animais e alimentos oferecidos às divindades, despesas da casa e pagamento das pessoas que trabalham nessas obrigações. E todos os envolvidos em alguma atividade ritual devem receber alguma quantia em dinheiro. Essa distribuição obedece a um critério hierárquico e de funções rituais: o pagamento para a "mão do pai de santo", do axogun (homem responsável pelo abate de animais), pessoas que vão limpar os bichos, que vão cozinhar os alimentos, que vão tocar e cantar. Embora a soma de dinheiro de uma obrigação chegue ao montante de alguns milhares de reais, as pessoas que trabalham e oferecem essas obrigações são, em sua grande maioria, muito pobres e vivem privações de todo tipo. Mesmo os grandes pais e mãe de santo possuem poucos recursos financeiros, quase nenhum dispõe de propriedades. Ainda hoje, poucos são os que têm automóvel.

O termo empregado pelo povo de santo do Recife para a distribuição do dinheiro é o de agrado, ninguém paga os servições religiosos, "dá um agrado", a explicação dessas situações é a de que seria impossível "remunerar" uma pessoa adequadamente pelos serviços religiosos, "não há dinheiro no mundo que pague uma obrigação" me explicou uma mãe de santo. Assim, as pessoas são muito ciosas da distribuição do dinheiro entre aqueles que trabalham em suas obrigações. No limite, é possível dizer que não deve haver acumulação do dinheiro. Há aqui uma analogia entre a relação com o dinheiro e a relação com os santos. Tanto pessoas quanto divindades trabalham umas para as outras, por meio das obrigações nas quais as pessoas trabalham, os orixás comem e podem trabalhar para seus filhos. Quando uma pessoa é avarenta, ou não distribui corretamente o dinheiro de acordo com a função desempenhada por cada um dos envolvidos, dizem que ela está comendo o dinheiro. Um mau sacerdote é aquele que não cuida dos orixás de seus filhos, que "só faz é comer o dinheiro do povo". Desse modo, o não recebimento do dinheiro por uma pessoa, ou o recebimento de uma quantia incorreta ou 
inadequada, pode sugerir que "alguém comeu aquele dinheiro". Esse é um sentido negativo da noção de comer.

Uma pessoa que ganha uma quantidade de dinheiro e não cumpre sua obrigação para com seu orixá ou entidade está “comendo o dinheiro que era pro santo”. Um pai de santo que realiza um grande número de obrigações e paga mal as pessoas que trabalham com ele é tido como alguém que está engordando às custas do trabalho alheio, comendo o dinheiro que era destinado a outras pessoas. Essa noção ainda é estendida para outras atividades ligadas ao universo dos candomblés, como as agremiações carnavalescas (maracatus, caboclinhos, afoxés). Às vezes, uma agremiação, ou grupo, não dá resultados, "só faz comer o dinheiro" de seu dono ou responsável. Um presidente ou dono de maracatu que não investe em seu grupo, nas fantasias e no pagamento aos batuqueiros, "só quer comer o dinheiro do maracatu".

O dinheiro deve ser distribuído de modo a circular entre as pessoas. As obrigações usam muito dinheiro, mas elas não se alimentam dele. O que alimenta os orixás são os animais, as comidas preparadas. São elas que despertam o axé. Os santos não consomem o dinheiro. E este, quando acumulado irregularmente, incide em um apetite voraz, deixa-se de se trabalhar para os santos, para comer o dinheiro.

Minha relação com meus amigos e interlocutores em Recife se estruturou por meio dos rituais. A própria antropologia, aqui, foi pensada nos termos do ritual, no modo como essas pessoas convencionalizaram suas experiências com outros antropólogos que desenvolveram suas pesquisas. "Você só poderá fazer sua pesquisa se passar pelas obrigações que José Jorge passou", disse-me Pai Paulo. O ritual é um modo de lidar com outras forças, com a diferença, com os antropólogos, portanto, não seria diferente. Meus amigos interpelam e abordam a antropologia a partir de suas posições, mediando esses encontros em seus próprios termos.

Em todo caso, minha integração com os diversos terreiros foi facilitada pelo trabalho em comum que desempenhamos, além dos momentos de conversa nos intervalos das obrigações. Foi com isso que obtive um acesso maior ao universo de pessoas que orbitam na rede de casas que compõe a família de santo, as quais me levaram a pontos de sua rede de parentesco.

São muitos os vetores que incidem na participação de alguém em rituais nagô. Muito além da linha divisória “de dentro" e "de fora", gênero, tempo, disposições pessoais e cargos figuram como tão, ou mais, importantes. Nesse sentido, gostaria de ressaltar outra dimensão do 
meu trabalho com o povo de santo do Recife. Em determinada obrigação, uma filha de santo me disse que era raro ver pessoas da minha cor realizando esse tipo de trabalho (segurar e limpar bodes, cabras e carneiros). Nos candomblés do Recife, os brancos são uma minoria no interior das casas de santo ${ }^{28}$ - há poucos pais e mães de santo brancos. Mesmo entre os clientes (pessoas que buscam a resolução de seus problemas, mas não criam nenhum vínculo mais profundo com essas comunidades), poucos são os brancos. Nesse sentido, em menor numero são os que efetivamente participam das atividades rituais, tidas como mais pesadas ou menos “aprazíveis".

A ausência ou raridade de brancos trabalhando em obrigações é um dado das casas de santo com as quais convivi. E em grande parte das obrigações e rituais dos quais participei ao longo de minha pesquisa, eu era o único presente. Como disse um ogan amigo: "nem todo mundo quer fazer o trabalho pesado, tem gente que prefere pagar a trabalhar. Esse é um trabalho pesado, tem que ser forte para aguentar, é coisa de negros mesmo". Essa força aludida por meu amigo é uma língua franca no universo das famílias para caracterizar o trabalho com os orixás - mais do que uma força física que possibilita a realização de certas tarefas, trata-se de uma força espiritual que prepara ou possibilita determinadas participações, de determinadas pessoas, em trabalhos rituais específicos. E conforme mostrarei nesta tese, a relação entre força, raça e família é recorrente no candomblé do Recife.

A surpresa daquela filha de santo sobre meu trabalho - uma pessoa branca que estava trabalhando em funções nas quais outros brancos daquelas comunidades, ou que passaram por ela, dificilmente realizam - diz respeito à segmentação do trabalho e das relações raciais internas ao culto. Mas também traz outra dimensão importante de ser ressaltada. Tão importante quanto sinalizar minha condição de iniciado no candomblé é refletir sobre minha presença enquanto branco em um universo de maioria negra, um tema que se convencionou ignorar, construído sobre a base de uma "brancura sem cor", que finge não reconhecer os privilégios de ser branco em uma sociedade de conflito racial (Carvalho, 2003).

\section{NOTA SOBRE REGISTROS, FALAS E GRAFIA}

\footnotetext{
${ }^{28}$ Ainda de acordo com o estudo da Pesquisa Socioeconômica e Cultural de Povos e Comunidades Tradicionais de Terreiros (2011), o percentual de pretos e pardos dos terreiros da Região Metropolitana do Recife é de 82,3\%, em face de $14,8 \%$ de brancos. Sendo o maior percentual de negros nas cinco regiões metropolitanas avaliadas: Recife, Belo Horizonte, Belém e Porto Alegre (Alimento sagrado, 2011, p.139).
} 
Como disse imediatamente acima, meu trabalho de campo se deu por meio da participação no intenso calendário ritual do nagô. Pude, com isso, participar inúmeras vezes das diferentes modalidades rituais, em suas diversas etapas. Era nesse contexto que podia também presenciar a maior parte dos debates e elucubrações das pessoas, as relações entre elas e entre as casas, etc. Quando não havia uma programação ritual específica, me dirigia ao terreiro, onde passava horas conversando com Pai Paulo, Mãe Lu e seus familiares.

A princípio, não fiz uso de gravadores nessas conversas, cuja presença deixava algumas pessoas desconfortáveis. Pai Paulo, por exemplo, sempre se retraia, ou se invocava, diante da possibilidade de qualquer gravação. Como censura velada ao uso de tal equipamento, ele me advertia que as invocações e palavras possuíam uma força, uma que seria prejudicial para quem não soubesse manejá-las. Ele relatou uma situação que exemplifica esse perigo: disse-me que muitas vezes seus filhos de santo gravavam, sem autorização, suas saudações e invocações, e depois decoravam e repetiam sem saber "o jeito certo de se fazer", como me contou com certa malícia:

“Uma vez, numa obrigação de Iemanjá, o ônibus quebrou e foi um grande problema. As pessoas tiveram de sair do ônibus e ficaram num lugar deserto até que alguém fosse resgatá-las. Iemanjá lá com a panela [29] para oferecer no mar e nada de dar certo. Sabe o que foi? Foram às invocações que eles fizeram errado, gravaram com o celular e não sabem como fazê-las (risos). Quem é bom já nasce feito e quem quer fazer não pode! [30]”

No final do meu período de campo, dias antes da minha partida de Recife, Mãe Lu, preocupada com o andamento de minha pesquisa, me chamou no terreiro e perguntou se eu não iria entrevistá-la. Respondi que o meu convívio ali e as nossas conversas eram de certo modo uma "entrevista". Mãe Lu assentiu, embora desconfiada. Eu então propus de revermos o que

\footnotetext{
${ }^{29}$ Panela de Iemanjá é uma das obrigações mais populares do nagô. Consiste numa grande festa, em que é preparada uma panela de barro, com comidas, flores, presentes, que é carregada para ser entregue em alto mar. A José Jorge de Carvalho (1984), foi relatado que essa obrigação era um grande ebó (oferenda).

${ }^{30}$ Essa frase, muito repetida por Pai Paulo, é reveladora sobre a natureza do conhecimento para ele. Curiosamente ela aparece em outras etnografias, como me chamou a atenção Lucas Marques, alertando sobre a recorrência dela na tese de Edgar Barbosa Neto, cito na integra: “'Quem é bom já nasce feito' não se opõe à idéia de que a pessoa possa aprender, mas sim à ideia de que possa aprender independentemente da relação ritual com o seu orixá de cabeça, a qual, de um modo geral, sempre se atualiza em uma casa específica.[...] O fato de que esse axé seja dado não exclui, como escreve Braga, o treino 'e a experiência com os mais velhos'. É pelo próprio fato de o dom ser dado que ele deve ser feito. É menos uma propriedade do que uma relação, a qual, por sua vez, pode se fortalecer pela mediação do ritual apropriado, passando então do orixá geral dono de sua cabeça para aquele mais específico que comeu nela. $\mathrm{O}$ enunciado 'ninguém me ensinou' está no mesmo plano conceitual que a ideia, continuamente repetida por Pai Mano, da raiz como algo que não foi inventado" (Barbosa Neto, 2012, pp. 94,98).
} 
escrevi e gravar suas falas. Por fim, ela pediu que eu gravasse e transcrevesse os cânticos da jurema e das rezas e ladainhas católicas para deixar para seus netos.

No entanto, é preciso explicar que todas as falas, eventos e situações descritas nessa tese foram permitidas pelas pessoas envolvidas, bem como a revisão e continuidade das conversas a que estas ensejam. Todos os rituais descritos também foram igualmente autorizados, optei por transcrever apenas dimensões publicas destas obrigações, aquelas costumeiramente abertas a outras pessoas, evidentemente, que sequer pensei em transcrever qualquer cerimônia que fosse minimamente tida como mais resguardada ou particular aos envolvidos. Em qualquer comentário que possa indicar seu emissor ou receptor, quando se constitui de uma reprovação ou critica, foram suprimidos os envolvidos, mesmo em relação as divergências sobre a sucessão do Sitio de Pai Adão, mesmo que previamente publicadas, foram pensadas de acordo com esse principio, todos os nomes que aparacem no texto e que foram descritos pelos pesquisadores anteriores, com a devida anuência dos envolvidos, serão mantidos.

Também nunca tomei notas em campo. Quando retornava para minha casa, após o campo, redigia, no caderno, os relatos e situações ocorridas. Essas situações serviam, muitas vezes, de mote para iniciar nossas conversas em outros momentos e desdobrar questões levantadas de modo a produzir mais "conversas" sobre os temas retratados aqui. No final, pude organizar meu argumento em torno dos assuntos mais frequentes dessas conversas. Certa vez, li que entre os malineses a repetição não é um defeito, mas uma forma esperada de se contar e reviver histórias. Com meus amigos, desconfio que seja um pouco esse o espírito. No início, me atormentava a ideia de não estar gravando nossos diálogos e, por ventura, não conseguir reproduzi-los com exatidão no caderno de campo, perdendo, em muito, o que ouvia. Dada a profusão de nomes, lugares e pessoas, sempre escrevia alguma informação errada no caderno. Com o tempo, ao escutar e escutar, várias vezes, essas histórias, fui me habituando aos nomes, já reconhecia os lugares, os pequenos detalhes da narrativa. Se a repetição em si não era um defeito, cada vez que ouvia, repetidamente, uma história, sempre havia um detalhe a ser acrescentado.

De todo modo, ao final do campo, com as questões mais estruturadas, gravei algumas elaborações de meus anfitriões sobre o tema de nossas conversas e de alguns assuntos que emergiam nas conversas entre eles. Mantive seus nomes, com sua autorização, porque considero que todo trabalho etnográfico sobre as religões de matriz africana, contribui - ao seu modo - em produzir uma memória de suas lutas, resistências e principalmente de sua criatividade. 
$\mathrm{Na}$ estrutura textual da tese, a parte mais descritiva de eventos e rituais se baseia nas transcrições do material contido nos cadernos de campo. Falas e citações por extenso, descritas nas páginas que se seguem, são transcrições desses registros. Tais falas e transcrições se encontrarão em forma de citação por itálico e entre aspas, quando no corpo do texto.

\section{Grafias E CONVENÇÕES}

Os recentes trabalhos da etnologia afro-brasileira têm adotado o uso de convenções ortográficas do idioma iorubá na grafia de palavras enunciadas pelas comunidades de terreiro, como, por exemplo, òrìsà para orixás, Èsù para Exu, entre outras. Neste trabalho, opto por transcrevê-las conforme as convenções ortográficas do português, em especial, para aquelas que já se encontram amplamente disseminadas em nosso vocabulário, como, por exemplo, Oxum, Iemanjá, Xangô. Essa opção visa apenas facilitar a leitura de pessoas não habituadas à grafia do idioma iorubá, mantendo o uso da grafia iorubá quando utilizado pelos autores citados.

Os termos em português utilizados pelos praticantes do nagô serão igualmente grifados em itálico, buscando evitar uma dupla naturalização de seu uso, ou seja, demonstrando que palavras como sangue, religião, herança, intuição, entre outras, podem possuir sentidos bem diferentes dos que adotamos para elas. Assim, minha intenção é destacar que apesar de "ser", em certo sentido, a "mesma" palavra, seus significados podem não ser os mesmos que, convencionalmente, mobilizamos para interpretá-las.

As falas das pessoas serão grafadas em itálico quando for uma exemplificação minha de seus conceitos, ou surgirem a primeira vez no corpo do texto. As citações antropológicas serão em aspas duplas quando aparecerem no interior dos parágrafos, ou seguindo as normas da ABNT. Os termos de parentesco empregados também serão grafados pela letra maiúscula, por exemplo: Pai Paulo, Mãe Lú, Tia Zere, Tia Inês. Do mesmo modo que os pronomes de tratamento: Seu Malaquias, Dona Josefa e assim por diante. Quanto as notações de parentesco, adoto as consagradas na literatura do tema, em inglês convencional (M, F, D, S, Z, B,H, MM, assim por diante)

\section{Capítulos da Tese}


O ponto de partida desta tese é a questão etnográfica relativa à relação entre "o santo" e "o sangue" na composição das famílias de santo no candomblé nagô do Recife. Os capítulos são uma maneira de expor diferentes modalidades de composição derivadas do dispositivo relacional principal do parentesco.

O contraste aventado acima, entre o sangue e o santo, é entendido a partir, e por meio, de sua natureza ritual. O parentesco é expresso e formulado pelo ritual. Os vínculos e diferenciações elicitadas tornam-se mais evidentes a partir dos complexos procedimentos envoltos na iniciação, tema do primeiro capítulo. A iniciação enquanto ato de ligação entre uma pessoa e seu orixá, e também dessa pessoa e uma rede de parentes (mãe, pai, padrinho, madrinha, irmãos), é o ponto inicial de descrição de um aspecto da relação entre santo e sangue. Nesse caso, as operações rituais servem para separar as linhas de santo e de sangue, evitando proximidades ou semelhanças excessivas - limite expresso pela interdição da feitura de uma pessoa por seu pai ou mãe consanguíneos.

Junto à iniciação, é sempre realizada uma obrigação para os antepassados, os eguns. Dessa forma, no segundo capítulo, ao estender a distinção santo e sangue ao território dos eguns, mostro como ela opera segundo outro tipo de aproximação e afastamento. Se na iniciação o ritual deve produzir a diferença entre o sangue e o santo, no caso dos eguns, a relação é de adição, e mesmo certa indiscernibilidade, entre a linha de santo e a linha de sangue, na medida em que antepassados espirituais e consanguíneos passam a ser cultuados (ainda que não inteiramente do mesmo modo). É a diferença de natureza das pessoas, dos eguns e dos orixás que requer, cada qual, tratamentos específicos produzidos deliberadamente pelo ritual.

No terceiro capítulo, faço uma descrição do quarto de santo, o peji, e da disposição espacial dos assentamentos dos orixás. Com isso, ressalto a dimensão relacional das entidades em seu aspecto material, dado que tais assentamentos estão no peji, de acordo com os relacionamentos míticos dos orixás traduzidos, em Recife, em termos de relações de parentesco e da consequente proximidade ou distância espacial entre eles. Esses assentamentos são, ainda, constitutivos da relação entre pessoas e divindades e presentificam o vínculo entre um iniciado e seus orixás, evidenciando um modo de composição entre santos, pessoas, casas e suas histórias.

O quarto e último capítulo retoma o tema das heranças espirituais, que atravessa todos os capítulos desta tese. Essas heranças condensam simultaneamente as linhas de sangue e de santo, que servem como contextos implícitos uma para outra e se desdobram sobre diferentes realidades a partir da noção de obrigação. Isso coloca o debate das heranças em relação a 
questões mais amplas da etnologia afro-brasileira, como sucessão de casas, heranças de santos e objetos rituais, noção de dom espiritual, interação entre diferentes modalidades religiosas e as possibilidades de retomada de conhecimentos e práticas dos antepassados. 
Figura 1 - Genealogias da Família Felipe da Costa

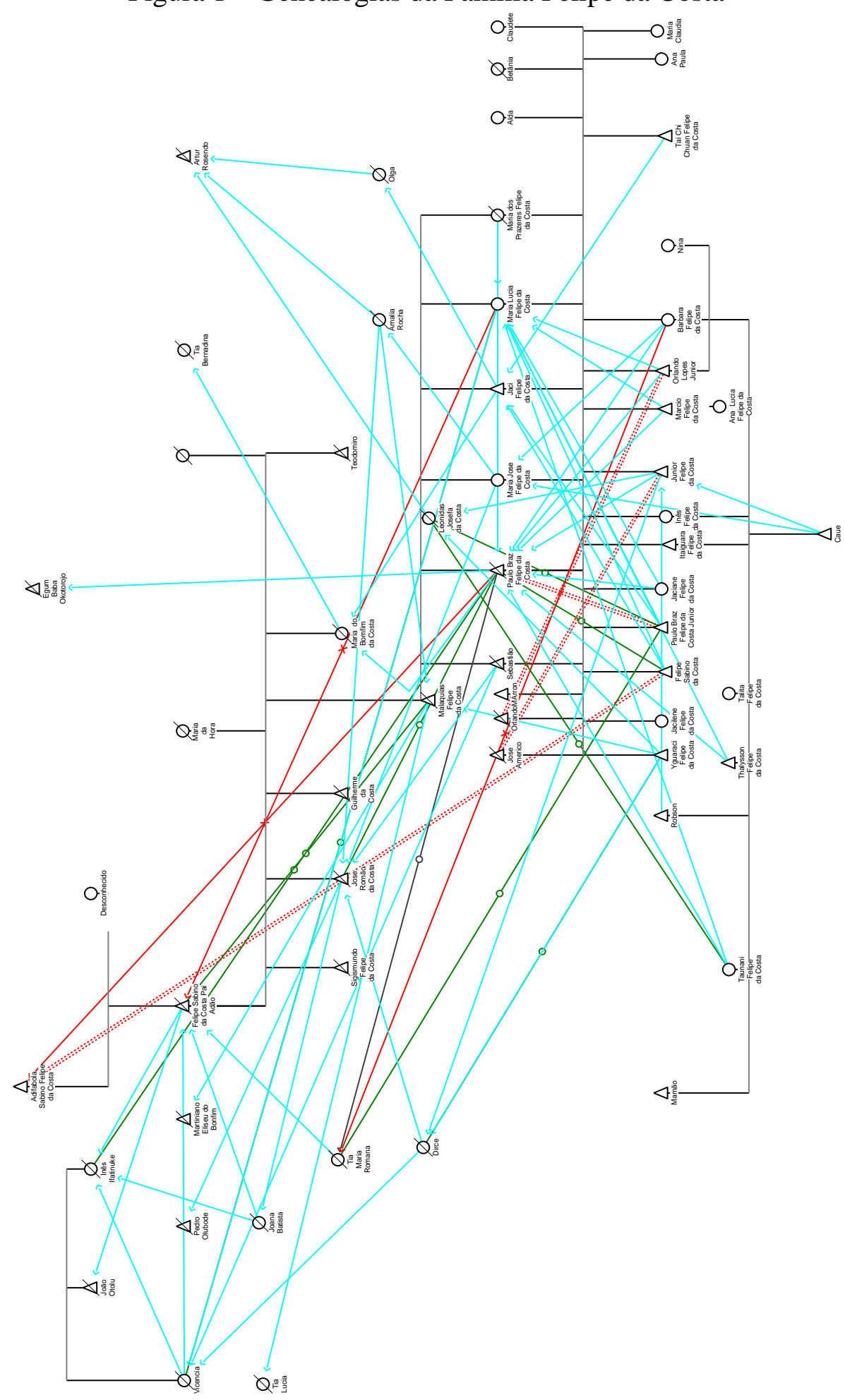

Legenda:

Traços contínuos em preto: relação de "sangue".

Traços contínuos em azul: relação religiosa ou de "santo".

Traços pontilhados em vermelho: relação de transmissão de nomes.

Traços contínuos em vermelho: relação de transmissão de nomes de "santo".

Traços contínuos em verde: relação de transmissão de assentamentos de orixás. 


\title{
Capítulo 1 - Parentesco Ritual
}

\author{
A religião dos orixás está ligada à noção de família. \\ (Pierre Verger, 2002, p.18).
}

Eu é um outro, uma multiplicidade de outros, encarnado no cruzamento de componentes de enunciações parciais extravasando por todos os lados a identidade individuada.

(Felix Guattari, Caosmose, op. cit., p. 105)

“O candomblé é uma familia mística que se superpõe às famílias carnais. Como se chega a fazer parte dessa familia?" (Bastide, ano, p. 50, meus grifos). O uso do verbo pronominal destacado na frase acima permite uma abertura a diferentes campos semânticos na mesma oração. No sentido de "sobrepor" enquanto verbo bitransitivo, entende-se que seu uso nessa frase exprime a ideia de "colocar antes de", "dar preferência". Esse primeiro sentido remete às leituras expostas na introdução sobre a natureza da família de santo nos candomblés do Brasil, em especial, na relação dessa com a família dita "consanguínea", cumprindo a "função" de fornecer às pessoas advindas de uma "experiência familiar desagregadora" um universo "coerente" de posições sociais, que permitiriam uma estabilidade em um meio marcado por incertezas.

Uma segunda leitura seria de adicionar uma coisa à outra: nesse sentido teríamos uma aproximação com o conceito de família de santo - tão caro aos meus anfitriões em Recife, pois, a partir das suas experiências com candomblé, traduzidas pelo termo "família", é possível vislumbrar diferentes engajamentos, relações e conexões que uma pessoa estabelece enquanto pertencente a uma família de santo.

A terceira possibilidade é a inversão dos termos para que o foco da análise seja a contraparte da família de santo, aquilo sobre o que ela se diferencia. Dito de outro modo, a família carnal sob a perspectiva da família de santo - como se ela também significasse outra coisa a partir das relações que a consanguinidade vincula, permitindo que a maneira habitual de associação ao significado desse termo possa ser transformada quando associado a essa experiência. Todas essas opções serão desenvolvidas na análise que se segue. São os seus desdobramentos possíveis e as reflexões que se suscitam no intercruzamento de significações, o interesse maior desse capítulo. 
Voltemos à indagação de Roger Bastide: “Como se chega a fazer parte dessa família?”. Por certo a resposta para essa questão se encontra na iniciação ou feitura de santo. Como se sabe, o termo feitura do santo deve ser entendido em sua literalidade, ou seja, um processo no qual tanto a pessoa quanto o santo são produzidos na interação entre ambos. O que está em jogo nessa interação é tanto a multiplicidade da pessoa quanto as diferentes modalidades de seres aos quais ela se liga por meio de uma série de diferentes participações místicas.

No Ilê Iemanjá Ogunté, é por meio da iniciação que os laços de parentesco consanguíneos internos à casa de santo são cristalizados em seu novo enquadramento. Quando uma pessoa decide ser iniciada no candomblé, só poderá fazê-lo após o veredito oracular, que revelará a necessidade da iniciação, justificada seja pela herança de algum orixá ou pelo intermédio de algum recado do santo ou outra entidade (e.g. um conselho de uma entidade da jurema), que sinalizará a importância da feitura sob a supervisão de um pai e uma mãe de santo. No Nagô, entende-se que iniciação é um longo processo que pode englobar sucessivas e progressivas cerimônias ou constituir-se em um único ato, lavar a cabeça, que garantirá o vínculo daquela pessoa com seu orixá e com seus iniciadores por toda a vida (retomo esse ponto com maiores detalhes mais abaixo).

Como informa a literatura antropológica sobre o candomblé, é por meio das cerimônias de iniciação que uma pessoa acede ao seio de uma comunidade como filho de santo de uma determinada linhagem ritual ou consanguínea. Esse movimento afeta simultaneamente os envolvidos, pois o filho de santo entra na linhagem como parte da casa, e a própria casa se insere na linhagem da pessoa quando futuramente esta abrir a sua própria casa. Se pudéssemos pensar em um diagrama das relações que esse parentesco ritual produz, veríamos como essa rede liga os humanos entre si e estes aos orixás.

Os autores da chamada "Escola Pernambucana" (Fernandes,1936; Valente, 1955; Ribeiro,1978) de antropologia, figurada por Roberto Motta(1990), engajados na reflexão sobre a relação entre o jogo de búzios e a atribuição dos santos em Recife, concordam que o jogo constituir-se-ia em um primeiro passo para a iniciação, já que, entre outras coisas, sua principal atribuição seria definir o santo de cabeça do acólito. Fora dessa "escola", Rita Segato (1984) possui uma visão semelhante a respeito do mesmo ponto, a saber: que a atribuição do orixá passa pela atribuição do jogo. Contudo, como ela aponta, o jogo muitas vezes confirma uma 
atribuição prévia por parte dos sacerdotes que analisam a personalidade, o tipo físico e certas características das pessoas - um conjunto de atribuições que associam as pessoas enquanto filhos de determinada divindade. Desse modo, muitas vezes o resultado do jogo de búzios pode variar de pai de santo para pai de santo.

Sobre isso, considero que essa variabilidade da atribuição permite avaliarmos duas possibilidades: a primeira é a própria variação (de maior ou menor grau) entre os orixás que falam nos odus entre um terreiro e outro ${ }^{31}$, o que implicaria na diferente atribuição de orixás em cada casa. Essa variação permite especular sobre a ausência de determinados orixás que não possuem filhas de santo no nagô, como Oxumare (ou Exumare, como dizia Pai Paulo), Ewa, Iroko, Oba e Logun-ede. Eles, embora conhecidos, não são feitos no nagô ${ }^{32}$. A segunda implicação dessa característica seria a "popularidade" de determinados orixás em relação a outros. Em Recife, há muito mais filhos de santo de Xangô, Iemanjá, Oxum, Orixalá e Oya do que de outros orixás como Ogum, Ode, Obaluaiye. Uma possibilidade de interpretação para essa frequência seria a de que o número de odus nos quais falam esses orixás seria maior do que aqueles em que falam outros orixás.

Contudo, mesmo existindo uma incidência maior desses orixás nos odus do jogo de búzios, a frequência em suas caídas varia. Por exemplo: mesmo que Xangô fale em determinado odu, o número de possibilidades de esse odu sair não é igual ao de outros. Há odus que caem com maior frequência e outros que muito raramente aparecem para alguém, como, por exemplo, o odu Ejobe Baba Malê - a caída desses odus são eventos tão raros, que mesmo sacerdotes de idade avançada nunca a viram ocorrer (cf. Halloy, 2005).

Há ainda outro problema. Afirmar que o pouco número de filhos de santo, ou a inexistência deles, está baseado no fato de que os odus nos quais falam esses orixás são reduzidos ou inexistentes é ignorar determinados atributos cosmológicos do nagô, que determinam que certos orixás não são feitos na cabeça de ninguém. Um exemplo é Ossaim, que mesmo falando em um odu relativamente frequente (Obixé), não é iniciado na cabeça de pessoa alguma.

A atribuição ou feitura de um orixá em uma pessoa implica ainda em outras possibilidades que estão para além da determinação do jogo. Pai Paulo, sobre isso, comentava:

"Você sabia que o amor de um orixá, a simpatia que a gente tem, pode mudar um santo na cabeça de uma pessoa, não sabe? [Visivelmente satisfeito com meu ar surpreso diante dessa informação, ele prossegue]. Às vezes, a pessoa é

\footnotetext{
${ }^{31}$ Conferir Halloy (2005).

${ }^{32}$ Orixás que são "feitos” no nagô: Ogum, Ode, Obaluaiê, Nanan, Oxum, Xangô, Oba, Oya, Iemanjá, Oxalá.
} 
de um orixá, mas se pega tanto de amor por outro orixá, ou tem tanta simpatia por ele, que o santo passa na frente do santo da pessoa, e fica ele com a cabeça dela.

[Eu não sabia disso, Pai Paulo, achava que o santo da pessoa era aquele que o jogo mostrava.]

É, mas também pode ocorrer isso, outras vezes o santo comanda e toma de frente mesmo, como Iemanjá.

[Iemanjá?]

É, aqui em casa mesmo, todo mundo é de Iemanjá ou tem ela como principal. Eu sou de Obaluaiê e Oya. Esse Obaluaiê foi um africano que viu. Na época que Raminho foi pra África, a gente era muito ligado - ele, eu e Cicinho. E o africano disse pra ele 'você tem dois amigos, um de Iemanjá (eu) e o outro de Xangô (Cicinho), esse de Iemanjá é porque Iemanjá considera a dona, mas ele é de Obaluaiê com Oya. E quando eu tinha 9 anos, na casa de Amália Rocha, que meu pai tomava conta, chegou Oyadolu e disse que eu era filho dela. Tenho Oya de herança espiritual da parte do meu bisavô. Um dia uma a Oya de uma filha de santo de meu tio me falou: 'você é meu filho'. Era Oyadolu. E tenho Ifá também. Meu Obaluaiê é herança de Tia Maria Romana, o assentamento tem mais de 300 anos. Aí, Ajibola ${ }^{33}$ me deu o nome 'Oman Babalaiye: filho de pai que tem o poder da casa da mãe'. Mas sou de Iemanjá, porque ela é a dona da cabeça da nossa família, que rege a gente, ela que toma a frente dos orixás na nossa família. Outras vezes, a pessoa tem um gênio muito forte, ou é muito nervosa, com raiva e agressiva. Imagina se o orixá dela for Ogum ou Xangô... Eu tinha um filho de santo que era muito bravo, tinha um coração bom, mas também gostava de fazer malvadezas com o povo, brigar, bater no povo. Ele era de Xangô, mas eu fiz ele para Orixalá, para ele ficar mais calmo, mais tranquilo e menos violento. "

No entanto, o processo de iniciação pode começar muito antes da feitoria e pode levar anos até que o iniciado seja coroado ou "feito" plenamente. Atualmente, esse é um motivo de

\footnotetext{
${ }^{33}$ Ajibola Isau Badiru é um amigo nigeriano de Pai Paulo, oriundo de Abeokuta, Doutor em Ciências Tecnológicas, professor universitário em Sergipe e que vive no Brasil há muitos anos.
} 
intenso debate nos candomblés nagô, sobretudo em relação a diferentes perspectivas sobre o que faz uma pessoa de fato iniciada ou não nessa nação.

O vínculo entre uma filha ou filho de santo e seus iniciadores é definitivo e se segue por toda a vida. Embora se reconheça que uma pessoa possa fazer outras obrigações posteriores à iniciação, com pais e mães de santo diferentes, entende-se que a primeira pessoa que "soprou o axé na cabeça" de uma filha de santo é a pessoa com a qual ela possui o vínculo mais forte.

De todo modo, o denominador comum aqui, em especial na minha etnografia, é a iniciação como fator definidor do estabelecimento da relação entre mães e pais de santos com seus filhos de santo. Uma passagem da etnografia de Jose Jorge de Carvalho ajuda a exemplificar esse ponto:

Eulina ía sentar sua Iemanjá e sentou-se no ate para submeter-se ao seu Obori somente de Obi. /.../ Logo após a maceração das folhas, Malaquias dirigiu-se a ela da seguinte forma:

Malaquias: "Olhe para mim. Há quanto tempo você frequenta esta casa?"

Elina: "Há sete anos".

Malaquias: "Sete anos. Você já sabe muito bem o que vai fazer, não sabe?"

Elina: "Sim, senhor, sei”.

Malaquias: "Não se arrependa depois, depois que você não a ganhar na loteria, depois que você não ganhar dinheiro. Isso é o que as pessoas fazem: a pessoa faz o santo; mais tarde, ela não ganha na loteria, não compra um arranha-céu (então diz): "Não sei porque fiz o santo; eu o fiz e o santo não me ajudou. Estou vivendo num lugar tão ruim, não consigo viver num lugar bom...” A maioria reclama daquilo que fez para o santo, mas não reclame. Se for o caso de arrepender-se por ter feito qualquer coisa dentro do santo, o momento é agora. Pois não se pode dizer depois que não se tem um arranha-céu, que você não tem isso ou aquilo."

Mãe de santo: "Se você não quer (lavar a cabeça), é agora (que você deve dizê-lo).

Malaquias prosseguiu:

Se você não quer fazer o santo, desista agora. Ainda há tempo suficiente, porque você ainda não entrou. Você está dentro do santo, mas você não entrou, realmente, no caminho que você está prestes a entrar agora: para adorar Yemoja. Yemoja não vai libertar você de doenças, você sabe disso. Aquilo que Deus determinou que passássemos em nossas vidas nós passamos por coisas boas; coisa ruins, bons tempos e maus momentos. Então você vai dizer: foram as mãos [34] do Sr. Malaquias que fizeram isso. Entende? Pense bem, de modo que você não possa dizer depois: as pessoas me aconselharam a não fazer e eu não as segui. Eu gostaria de não ter feito o santo com ele. Oh, suas mãos, eu não sei .... (ele ri um pouco). As pessoas podem dizer: foi a mão dele, foi a mão da mãe de santo.

Malaquias continuou: Alguém poderia dizer: acho que não era dela; foi o senhor Malaquias, porque sua mão está deformada. Minha mão é assim. Olhe: direto, todos

\footnotetext{
${ }^{34}$ Edgar Barbosa apresenta a conexão no candomblé entre a cabeça do iniciado e a mão do iniciador, atento à centralidade dessa relação no momento da feitura de uma pessoa. O candomblé entendido também como "religião da mão", tendo no verbo "fazer" uma expressão que condensa e potencializa essa relação: "De resto, a aproximação entre o orixá e a pessoa, no rito de iniciação, é feita pela mediação da mão do pai-de-santo. Como quer que seja, esse último é aquele que pode, se assim o quiser, atuar dos dois lados.” ( Barbosa, 2012, p.285).
} 
os dedos no lugar certo. É Deus em primeiro lugar, Deus Todo-Poderoso; Deus, o criador do céu e da terra.

Osayin Obenigi Yemoja Ogunté Oba Koso Kuse Kuleni Ibinja Alafin titi eka kiserebinu Ori Ob’Oba Oba Kuleni,

Tenho setenta anos e ainda não tenho a casa em que vivo; meu filho paga o aluguel por mim. Desde o dia em que nasci estou dentro do santo, mas não possuo uma casa. Eu trabalhei, lutei, tenho lutado por toda a minha vida. Eu tenho lutado como trabalhador, como balconista, mas não alcancei além disso. Mas também não morri de fome nem estou arrependido. Eu não morri de fome e os santos sempre me ajudam: eu acordei hoje sem um centavo, mas de alguma forma o dinheiro apareceu.

Mãe de santo: "Venha, faça-o em nome de Deus e de Iemanjá".

Malaquias: Em nome de Deus e de Iemanjá, faça-o com fé, faça-o com coragem, faça-o para amar a Deus e Iemanjá" (Carvalho, 1984, p. 303).

Vivaldo da Costa Lima, por exemplo, ressalta o aspecto compulsório da iniciação em relação ao orixá e à pessoa, tal compromisso [e pensando em termos dos próprios praticantes do candomblé como uma “obrigação"]. Essa obrigação, e o caráter inescapável de tal desígnio, é muitas vezes fonte de atrito do postulante a iniciação e sua família consanguínea. Para Vivaldo,

Certo é que o filho de santo não repudia ou ignora sua mãe ou seus colaterais, mas o candomblé, quando as duas noções de família não se confundem- o que já viu ser raro, é que funciona socialmente como meio para as projeções existenciais do indivíduo e como sua base de colocação social, de segurança e de mobilidade na sociedade mais ampla (Costa Lima, 1977, p.161).

Uma exceção, segundo o autor, se daria quando essa mesma pessoa possui uma trajetória que já faz parte do candomblé. Nesse caso, diz Vivaldo, o processo de aceitação por parte da família consanguínea é natural, e pode ir além:

em certos terreiros de tradição unilinear no sistema de sucessão e que a linhagem da família biológica se confunde com a linhagem da família de santo, o orixá da criança é olhado logo depois do nascimento e o grau de iniciação parcial ou total é decidido nesse momento" (Costa Lima, 1977, p.64).

Um desses casos, encontrado em seus exemplos, foi colhido no terreiro do Alaketu em Salvador, onde oito filhos consanguíneos da mãe de santo teriam obrigação de santo feito e alguns desempenham funções que foram de "velhos" tios da casa, usando os mesmos oyes (títulos rituais) dos parentes já falecidos (Costa Lima, 1977, p. 65).

Aqui reside um dos pontos de divergência que procurarei descrever neste trabalho em relação a essa perspectiva aventada por Vivaldo da Costa Lima: a distinção entre sangue e santo pode ser de oposição em algumas atividades rituais, mas não seria de saída uma norma 
prescritiva de um sistema de parentesco. É evidente que o cerne da questão pode ser traduzido em termos de sua diferença, e esta é sempre contextual e mediada. Uma leitura que estabilize essa diferença enquanto um a priori tende a congelá-la, como se esta existisse fora da relação por ela precipitada, assumindo que se trata de um fenômeno do tipo binário sangue $\mathrm{x}$ santo. Mas, ao menos na aposta que faço aqui, este seria um fenômeno muito mais analógico ${ }^{35}$, ou seja, uma frequência que se estabiliza momentaneamente a partir do ritual, que a modula a partir de um determinado impedimento, mas que a todo tempo a tensão tende a se recolocar.

Edgar Barbosa (2012), ao analisar uma situação sobre a ocorrência desse interdito nos terreiros de Pelotas, descreve que a interdição ritual entre a "filiação consanguínea" e a "aliança do casamento" evitaria a sobreposição da primeira pela última. Esse impedimento tende a ser contornado pela iniciação de pessoas nessa situação por algum parente colateral de geração alternada. Contudo, aponta o autor, esse afastamento não é absoluto:

[...]demonstra que a "mãe-de-ventre" passa alguma coisa para a sua filha, da mesma maneira que Mãe Michele, por trabalhar junto com Pai Mano na religião, está sempre aprendendo com ele. Se há separação em um plano, há aproximação em outro, e assim a pessoa pode, ao fazer a sua casa, herdar lados dos dois lados e/ou então aprender com mais de um chefe os fundamentos rituais de um único lado. Note-se ainda que se a cabinda de Pai Mano vem de seu tio e do pai-de-santo dele, o lado de umbanda e de quimbanda, que começa a ser praticado em sua casa vem, principalmente, pelo lado de Mãe Michele e daquilo que lhe foi transmitido pela sua avó paterna, que, durante muitos anos, foi cacique de terreira (Barbosa, 2012, p.118).

Essa discussão deve levar em conta o modo como os praticantes do candomblé, organizados em famílias de santo, dispõem suas relações e elaboram seus relacionamentos rituais. De partida, os dois casos do contraste aventado acima, "o sangue" e "o santo", só fazem sentido a partir e por meio de sua natureza ritual. Seus vínculos e a diferenciação que elicitam tornam-se mais evidentes a partir dos complexos procedimentos envoltos na iniciação. Passo a isso agora.

Se nos mantivermos nesse regime analógico das conexões entre humanos, alguém em iniciação também reforça seu vínculo para com um orixá em particular, seu "santo de cabeça" ou "anjo da guarda"; esse novo orixá está relacionado aos iniciadores e aos seus respectivos orixás, que o assentaram e alimentaram nesse momento. Salientando que, no idioma do ritual

\footnotetext{
35 Apoio-me aqui na discussão de Roy Wagner (1977) sobre o “O Parentesco Analógico: um exemplo Daribi”, e as questões que se seguem possuem ressonância com o argumento dele nesse texto, em especial a noção de que o parentesco constitui um fluxo existente a priori e que deve ser constrangido a partir de ações deliberadas com o objetivo de diferenciar as pessoas criando comportamentos adequados e desejáveis a partir da troca. Em relação ao meu argumento me interessa a ideia de que do fluxo geral, que nesse caso é o dom, há a necessidade (obrigação) de singularização como condição da confirmação das relações pregressas de parentesco.
} 
de iniciação, o principal ponto é que o pai e mãe de santo, junto aos seus orixás, "dão à luz" ao orixá do filho de santo (embora eles, muito provavelmente, sejam de orixás distintos). Uma fala de um jovem pai de santo explicita isso:

"Você viu essa menina que Tia Lu pediu para eu confirmar o jogo para saber o santo dela? Estava entre Iemanjá e Orixala, mas no meu jogo ele falou na frente. Iemanjá é mãe, ela é assim, na casa dela todo mundo abaixa a cabeça para ela, ela fala mais alto. Mas na minha mão ele vem falando na frente. É o meu axé, sou filho de Orixala Oguian Deyi. Então minha navalha vem trazendo ele. Veja meus filhos de santo, sempre tem Orixalá, ou de frente, ou como segundo santo. Na nossa família também é assim, né? Todo mundo tem Xangô ou Orixalá. Já era assim... Com Vô Adão... Oya também, nossa herança do sangue, a parte dos eguns... E Iemanjá que é a dona da casa, do Sítio, mas Xangô e Orixala são os santos da família também. Sempre tem ou como primeiro ou segundo, são os santos nossos, de família... da família."

Os praticantes do nagô frequentemente vinculavam essas duas cadeias de relação, a humana e a divina, na composição de suas famílias dentro das casas de santo. Esses vínculos não são apenas expressões dessas cadeias, mas antes as dispõem de modo a serem passíveis de transmissão. Nesse sentido, a iniciação não apenas instaura ou confirma uma relação entre a pessoa e seu santo, mas também estende a relação entre estes e seus iniciadores e seus próprios orixás. Além disso, outros termos entram nessa variável, como a casa, a nação da casa e a nação do pai e mãe de santo. Sobre esse ponto, Carmem Opipari aponta para a centralidade que o termo "santo" adquire nessas relações:

O termo santo integra um grande número de expressões. Na rede das relações que compõem o grupo religioso, família de santo: pai ou mãe de santo, filho ou filha de santo, irmão ou irmã de santo, avô ou avó de santo, e assim por diante. No contexto da iniciação: fazer o santo, raspar o santo, ser feito de santo ou ser feito no santo, ter santo. Para assinalar o pertencimento: ser do santo, povo de santo. No campo da possessão: virar no santo, ser pego pelo santo, estar no santo, dormir no santo, dar santo [...] ( Opipari, 2009, p.183).

Esse ponto tornou-se explícito para mim a partir de uma obrigação feita por Bino na casa de uma antiga "tia de sangue" (prima ${ }^{36}$ de seu pai), cuja casa é vinculada à nação xambá, mas que ao mesmo tempo continha orixás cultuados no nagô. A mãe de santo assegurava a

\footnotetext{
${ }^{36}$ Em geral, nas famílias com as quais convivi em Recife, primos dos genitores, ou de ego, mas em em idade aproximada ao dos genitores, costumam ser denominados como tios.
} 
necessidade de Bino fazer a obrigação para Exu e Iemanjá, uma vez que esses santos eram nagô, enquanto os outros vinham da nação xambá:

"Estava esperando para você cortar para Exu, o exu daqui é nagô, foi seu avô [Malaquias], meu pai de santo, que assentou, assim como minha Iemanjá, mas os outros santos são Xambá, minha mãe de santo era xamba, eu fui feita numa casa Xambá, ela depois passou para meu pai [José Romão]. Em casa faço assim, o Exu e Iemanjá são nagô, santos do meu pai de santo, o restante é xambá, como eram os santos da minha mãe [nesse caso há uma indeterminação em relação a qual mãe a sacerdotisa se referia, dado que tanto sua mãe consanguínea quanto sua mãe de santo eram oriundas de uma casa xambá]."

Aqui é possível acrescentar outra analogia. No momento em que uma pessoa assenta seu santo, entende-se que ela recebe um orixá que será seu pai se for um santo masculino e outro que será sua mãe caso seja filha de um orixá feminino, a depender dos santos que possua em sua cabeça como orixá principal, de modo que é comum ouvir as pessoas se referirem aos seus orixás como "minha Mãe Iemanjá”, "meu Pai Xangô”. Essas relações podem ser traduzidas mediante metáforas de filiação, das quais é frequente a comparação tanto da filha de santo quanto com seu orixá, ambos pensados enquanto "recém-nascidos".

Dessas falas podemos apreender que os rituais de iniciação produzem laços adicionais. O principal deles é aquele que insere o iniciado na linhagem ritual de seu pai e sua mãe de santo; a segunda é a que vincula o iniciado ao seu padrinho e madrinha de santo — as segundas pessoas imediatamente após o pai e a mãe, peças fundamentais dos rituais de iniciação. Uma pessoa pode, inclusive, ter dois/duas padrinhos e madrinhas e, em alguns casos, pode até mesmo ter um orixá ocupando esses cargos. Uma antiga filha de santo de uma tradicional casa em Recife me disse certa vez que todos daquela casa tinham o costume de chamá-la de madrinha, replicando o vocativo dela própria, ao de sua mãe de santo, a quem também chamava de madrinha:

"Minha mãe de santo era madrinha de batismo de igreja de minha mãe, então eu e minha irmã a tratávamos como 'madrinha'. Os filhos de santo mais novos de minha mãe de santo me chamavam de madrinha também, "madrinha isso", “madrinha aquilo”, então eu batizei todo mundo na fogueira de São João, de São Pedro. Eu não era madrinha? Então tinha que oficializar isso, agora todo mundo aqui nessa casa é meu afilhado de direito. ' 
Como veremos, os padrinhos e, em especial, as madrinhas de santo atuam enquanto "assistentes do pai e mãe de santo". Eles que ajudam a criar o recém-iniciado, e as pessoas costumam referir-se a eles pelo termo iorubá de Ajibonan, "meu ajibonã que me deu caminho", "meu Ajibonã que me criou no quarto". Outro papel do ou da Ajibonã é o de sempre alimentar e cuidar do novo iniciado, tratando como bebê recém-nascido durante a maior parte das cerimônias de iniciação. Ambos, madrinhas e padrinhos, se tornam também, em um grau hierárquico levemente menor, os "pais e mães" que analogicamente tornam-se os pais e mães rituais que cuidam e criam a filha junto aos pais e mães de santo.

Esse conjunto de zeladores (pai, mãe, madrinhas, padrinhos) pode ter configurações distintas no que concerne às suas próprias filiações. Apesar de preferencialmente todos os iniciadores serem de uma mesma casa, não é estranho que cada pessoa implicada na iniciação possa vir de uma casa distinta e, mais ainda, pertença a nações diferentes. O que precede ou sucede essa combinação é necessariamente que essas distintas pessoas estejam ligadas a casa onde a ou o iniciante será feito por meio de algum laço de parentesco consanguíneo ou ritual - neste ponto equivalem-se tanto os laços de sangue quanto os de santo. Nesse sentido, é costumeiro referir-se às pessoas com as quais se compartilha uma relação como "filhos da casa".

Nessa direção, os outros filhos de santo da casa em que a pessoa se iniciou se tornam seus irmãos de santo; [note-se que não necessariamente todos os filhos de santo de seus iniciadores serão também seus irmãos e não apenas os da casa onde se iniciou]. Os iniciadores de seu pai e mãe de santo serão seus avós de santo e os fundadores da linhagem se tornam ancestrais rituais. Em muitos casos, são fundadores de uma casa - ou ainda precursores dessas nações, como é o caso da família de Pai Adão. Os ascendentes consanguíneos falecidos do iniciado serão igualmente considerados em suas obrigações como ancestrais, mas só contarão para seus futuros filhos de santo se forem pessoas do "santo". Todos esses vínculos acompanharão a filha ou filho de santo ao longo de sua vida, e possivelmente terão efeitos sobre seus filhos, rituais e consaguíneos, que farão parte de sua "família no santo". De todo modo, a mais importante relação nesse universo é a filiação de uma pessoa a um pai e mãe de santo, nesse ponto me associo à consideração de José Jorge de Carvalho:

O culto mantém-se em grande medida graças à barreira intransponível caracterizada pelo relacionamento entre pai e/ou mãe de santo versus filha ou filho de santo. Considero extremamente significativo e importante, assim, que a relação básica de parentesco em torno da qual os cultos se organizaram é feita evidente e expressa durante o momento crucial desse ritual chave do culto xangô. Todos os outros relacionamentos que vimos em operação dentro do culto, tais como aqueles entre irmãs ou irmãos de santo, padrinho ou madrinha e afilhado, pais ou mães de santo, pai 
de santo e seu ajudante, um filho de santo e iyabá, e assim por diante, não são muito estáveis nem tão pouco sempre definidos ou duradouros. Uma mulher pode servir de iyabá do santo de outra, mas pode ser uma obrigação temporária; um homem pode ser axogun de um pai de santo intermitente, e pode até mesmo revezar com um outro axogun; e assim por diante. A ligação que se pode estabelecer aqui é a de que aqueles relacionamentos que são menos constantes não aparecem em nenhum momento ritual de importância crucial, enquanto os relacionamentos realmente básicos o fazem (Carvalho, 1984, p.338).

Vimos até agora os diferentes pontos constituintes de uma família de santo, que se configura tendo o iniciado, seus novos parentes, orixás e parentes consanguíneos (vivos ou falecidos). A família de santo, como bem apontou Halloy, se configura como uma rede, "a rede nagô" (2005, p. 131), e essa rede é nomeada, pelos praticantes do candomblé em Recife, como rama. Ao se referir a uma pessoa, meus amigos frequentemente a localizavam como "fulano é da rama do Sítio" ou "ciclano vem da rama de Seu Raminho". Essa rede é formada pelas casas ligadas aos principais líderes da família de santo.

Essa rama serve para informar também sobre o intenso calendário de rituais, ao vincular diferentes casas, de modo que as obrigações sejam sempre marcadas em relação à casa matriz. Desse modo, o calendário de festas é rigorosamente marcado de acordo com as obrigações da casa principal dessa rede, em geral a mais antiga ou aquela liderada pelo pai ou mãe de santo do fundador de um terreiro. Dessa maneira, as outras casas devem marcar suas festas em datas alternativas. Por exemplo, novembro é o mês em que se realizam as obrigações de Iemanjá. As casas que compõem essa rede tendem a ajustar seu calendário de obrigações para Iemanjá em virtude da obrigação na casa matriz à qual são vinculadas. Na mesma medida, quando uma mãe ou pai de santo começa a desvencilhar suas atividades rituais da pessoa que costumeiramente conduzia as obrigações em sua casa, seja por razões de briga ou fissão, em geral, passa a coincidir suas festas e obrigações com as datas estabelecidas para a festa da casa à qual outrora essa pessoa era ligada.

Outro termo recorrente utilizado para se referir a família de santo é raízes - um uso que lança mão de uma curiosa inversão. As pessoas não se referem a uma raiz à qual se vinculam, mas sim a elas mesmas como parte dessa raiz; por isso o termo é conjugado sempre no plural: "sou raízes de Ojébii", "sou raízes de Pai Adão”. E aponta para a continuidade futura dessa raiz. Como me ensinou Paulinho:

"Aqui na família cada um é um seguimento. Eu, Bino, Junior, Marcio, cada um é um seguimento, desde criança já damos sequência àquilo que nosso avô fazia, painho, Tia Lú. Somos raízes mesmo de Ojébii, lutando pra manter o que ele passou, ensinou, fazendo do jeito que ele fazia. Guará também, ele era muito apegado ao meu avô..." 
O termo seguimento pode ser pensado em parte como uma sequência, um encadeamento dentro desse fluxo de relações, se pensarmos nas pessoas da família dentro de uma sequência cronológica. Mas pode-se entender, também, seguimento como segmento, ou seja, um corte que secciona esse fluxo em outras partes - deste modo, a continuidade deixa de ser necessariamente pensada enquanto réplicas literais dos "pontos iniciais", para ser entendida como o corte que produz essa continuidade e que prevê também a diferença. Um modo de segmentação, de forma que cada pessoa é uma sequência desse fluxo familiar e simultaneamente uma composição dessas relações.

Desse modo, a perspectiva de uma pessoa (ou seja, o ponto que ela ocupa entre as relações) e por extensão a casa à qual ela se vincula é que modela e dispõe sua rede. Descrevo a história de um jovem filho de santo para ilustrar esse ponto. Esse rapaz, a quem tratarei como ego, fez seu santo em um terreiro nagô. Seu pai de santo é ligado por laços consanguíneos ao terreiro de Mãe Lu. Seu pai consanguíneo (F) era ligado a uma tradicional casa xambá e tinha em sua própria casa seus santos e sua mesa de Jurema. Sua mãe (M) era neta de uma famosa mãe de santo (MMM), que chegou a ter uma casa que concorria com o Sítio em grandeza e respeito entre o povo de santo do Recife. Essa antiga mãe de santo (MMM) foi feita por Arthur Rosendo e, com a morte dele, passou a cultuar seus santos ao modo nagô. Portanto, a mãe (M) desse rapaz (E) foi iniciada na casa de sua avó já nos preceitos da nação nagô. Atualmente ela faz suas obrigações na casa de um famoso pai de santo da nação jêje e é prima consanguínea do atual pai de santo do Sítio. Essa senhora é, ainda, madrinha de santo do pai de santo de ego. Os irmãos consanguíneos (B’s) de ego são filhos de santo de casas com nações distintas, xambá e jeje, de modo que sua rede vincula, a partir de seus laços consanguíneos, três nações e quatro casas de santo.

Podemos encontrar uma composição similar nos materiais etnográficos de Miriam Rabelo, a respeito dos candomblés da Bahia:

\footnotetext{
O terreiro não apenas recria uma estrutura familiar particular - que pode se mostrar um meio poderoso para inserir novos membros -, como incorpora, também, familiares de adeptos, compondo-se de redes cruzadas de parentesco de sangue e afinidade. Praticamente todas as pessoas que acompanhei estão cercadas de irmãos de santo que são também seus parentes de sangue - pais, tios e tias, avós, filhos e netos. Dona Detinha tinha vários parentes no terreiro de Mãe Beata (ao qual se vinculou depois da morte de sua mãe de santo): três filhos, uma nora, três netos. Na casa de Mãe Beata estão também a mãe e o tio de Rosinha, bem como a filha de Toia e uma irmã de Fernanda (além de sua mãe, que é frequentadora assídua), a filha de Gleibe e, durante certo tempo, também a esposa de Rafael; além, é claro, da própria rede de parentesco de Beata. O filho de Zulmira é ogã suspenso no terreiro de João, onde também sua filha é equede; os dois filhos de Josefina também pertencem ao terreiro em que ela foi iniciada. Lisa é feita no terreiro de sua tia; Zita frequentou por muitos anos o terreiro a que pertencia sua mãe de sangue; Genildo e Iracema vincularam-se desde crianças
} 
aos terreiros frequentados por seus pais; e a mãe de santo de Jucélia é sua tia de sangue. As mães de Pedro, Joanildo e João são adeptas ou frequentadoras assíduas de seus terreiros (Rabelo, 2014, p. 64).

Como apontou Halloy (2005, p. 122), “a escala das redes descritas pode variar muito de uma casa de culto para outra, ou mesmo de um indivíduo para outro, particularmente de acordo com seu status hierárquico, sua história pessoal nos cultos afro-brasileiros”.

Por fim, cada filha de santo incorre em obrigações anuais para seus orixás, as chamadas renovações, bem como contribui para as obrigações dos principais orixás de seus iniciadores e aos santos da casa em que foi iniciada. Finalmente, ao cabo de no mínimo sete renovações, os filhos de santo poderão também iniciar outras pessoas e eventualmente abrir a sua própria casa de santo. Novos elos são, assim, produzidos na hierarquia ritual da família de santo. Os praticantes do nagô recorrem às suas redes rituais sempre que se envolvem em atividades religiosas, continuamente restabelecendo os elos que compõem suas casas de santo. Toda obrigação, ou renovação, inicia-se com uma obrigação a cabeça da pessoa, como descreverei abaixo.

\section{ORI}

"A cabeça é quem sustenta o corpo" essa é uma máxima que ouvi muitas vezes entre meus amigos no Recife. A cabeça, ou o ori, pode referir-se tanto à pessoa, suas singularidades e especificidades, quanto ao seu anjo da guarda (ver Carvalho,1984; Segato, 1984; Halloy, 2005). Há diferentes maneiras de explicitar essa relação. Em sentido metonímico, o ori é o "corpo", ou seja, a materialidade da pessoa que será alvo de manipulações rituais que promovem seu bem-estar físico e psíquico. Uma explicação de Pai Guara para o antropólogo Arnaud Halloy explicita esse ponto:

O ori, a cabeça, é a parte principal do ser humano. Isto é a coisa mais importante pela qual você escuta, respira, olha, pensa, raciocina. Tudo isso está relacionado ao corpo, deve estar completo, é por isso que devemos alimentar (...). Você tem que cantar e falar com todo o seu corpo, porque sem sua cabeça, seu corpo não irá adiante e sem seu corpo, sua cabeça não será capaz de raciocinar. Se você não tem um corpo, onde ficará sua cabeça? E o que suporta o corpo? A cabeça. E o que sustenta a cabeça? O corpo é um conjunto. É por isso que você tem que dizer "ori oju okan". Quando terminamos, cantamos "ara lowo dj'ori gbé", "ara" significa "pessoas" e, portanto, todos devem prestar homenagem ao seu anjo da guarda. Ele se refere a todas as partes do corpo e também aos presentes, bem como ao anjo da guarda dos presentes para pedir [na forma de votos] os seus e que os seus os deles. É uma comunhão, que não deixa de ser uma fraternidade (Halloy, 2005, p. 152). 
Segundo José Jorge de Carvalho, “Ori significa basicamente ‘cabeça’ e no contexto Ifá vem a significar o corpo inteiro [...]. Ao ingerir uma bebida alcoólica, fazer sexo ou brigar, o ori da pessoa não fica na melhor condição de protegê-la" (Carvalho, 1984, p.67). Essa dupla dimensão do ori ser ao mesmo tempo físico e espiritual aponta para um modo de equacionar multiplicidades comuns às religiões de matriz africana, de não se reduzir "ao princípio da identidade e da não-contradição" (Bastide,1989, p.374).

A cabeça seria ainda a morada do orixá na pessoa. Outros sustentam que seria através da cabeça que o orixá entraria no corpo de seu filho de santo "Oxum quando vinha em terra me dizia, apontando para o ori, diza eu vou entrar aí!”, ouvi certa vez de um filho de santo. Ao entrar em contato com outros territórios religiosos, a cabeça deve ser protegida para resguardar o santo. Desse modo, se a pessoa frequenta uma cerimônia de Jurema, deve estar com a cabeça coberta - se for homem com um chapéu, se for mulher um pano de cabeça, pois se entende que a "fumaça ofende o santo". Essa analogia, entre "a cabeça ser do santo" e "o corpo da Jurema" é frequente, como uma mãe de santo dizia: "minha cabeça é de Oya, do santo, mas meu coração é dos espíritos. Eu posso ficar aqui sem cobrir a cabeça, porque Oya é da fumaça, rainha dos espíritos, ela gosta da Jurema, ela comanda o balé". Outra filha de santo dizia: "o santo é uma mão e a Jurema é outra, um é o garfo e o outro é faca, ninguém come só com uma mão".

Essa distinção não seria apenas relativa às partes componentes de uma pessoa e sua relação com as entidades. Há também um modo específico de composição implícito nessa divisão. As pessoas do nagô costumam distinguir o tipo de ação dos orixás e dos espíritos. Os orixás possuem uma pessoa, enquanto os espíritos trabalham e brincam: "os orixás atuam no orí, os espíritos brincam e usam a carcaça", ouvi de uma senhora, antiga tanto na vida do santo quanto na vida da Jurema.

Desse modo, os orixás atuam no ori de seus filhos. Essa noção de filiação me parece sugestiva para a questão sobre o tipo atuação específica dos santos. Alguns sinais como aparência física, traços de personalidade e alguns comportamentos seriam explicados por essa influência. Rita Segato elaborou uma etnografia de grande alcance sobre esse tipo de "atuação" traduzida em termos de um discurso arquetipical ${ }^{37}$.

Para os iorubás, o mestre da cabeça [ori] e a divindade pessoal [orixá] são entidades diferentes, sendo a primeira responsável pelo destino e pela personalidade, enquanto

\footnotetext{
${ }^{37}$ Portanto, eu estaria inclinado a concordar com a opinião de Goldman sobre o ponto, que enfatiza que essas referências "são apreendidas com uma mente mais icterícia do que séria, e que (as pessoas) não acreditam que elas refletem algo muito essencial" (Goldman, 1985, p. 99).
} 
na religião Ifá são a mesma entidade e não são. Responsável apenas pela personalidade (1995, p. 84).

Arnaud Halloy, a partir de sua etnografia, introduz uma ressalva a respeito dessa questão que deve ser levada em conta. Ao menos nas gerações atuais da família de santo, a separação entre a pessoa e o orixá tende a ser expressão das atitudes comportamentais e de personalidade radical. Contudo, discordo do argumento que atribui a "discursos ambientais" e ao papel central da educação e da "influência de mecanismos educacionais mais amplos do qual essas pessoas estariam inseridas" a explicação para tal diferença (2005, p. 167).

Neste ponto, retomo uma elaboração de Paulinho sobre essa distinção:

"Ela veio falar que é doida assim porque é filha de Oguian, que o povo de Oguian é tudo doido. Nada a ver isso! Eu sou de Oguian e não sou doido! Isso é da pessoa. O Orixá atua em uma pessoa, mas não atua em tudo não. Que nem aquela mulher que deixou o santo porque os filhos entraram no mau caminho. Painho falou que o orixá não muda o mau caminho das pessoas. Eles são os primeiros a se afastarem quando alguém tá mexendo com drogas e essas coisas. Então tem que saber separar. Outro dia ela veio falar que fulano seria ogan do santo dela. Onde já se viu isso? Quem determina essas coisas é o orixá, o orixá e não a pessoa. Tá errado! Senão todo filho de Ogum seria briguento e não é. Tem um filho de Ogum que é policial, ele é todo tenso, mas isso é da profissão dele, do serviço e não do santo."

Desse modo, o ori seria a morada do santo, mas não o próprio santo. Como exemplo, alguns advogam que uma pessoa que possua Orixalá pode receber um pouco de azeite de dendê no amassi (mistura de ervas e outras substâncias) que vai para o seu ori, apesar de o dendê ser um alimento proibido para seu orixá. Outros sacerdotes argumentam o oposto: como Orixala também reside ali, corre-se o risco de irritar o santo. Não há uma regra definitiva sobre isso e, no limite, tudo será determinado pelo jogo de búzios para saber se o ori aceitará ou não. De todo modo, é frequente a afirmação que o obori é para a pessoa e não para o santo ${ }^{38}$.

"Quem tá sendo cultuado ali é o ori da pessoa e não o santo", disse-me Bino, ele prossegue,

"Você pode até chamar o orixá no final, ou ele responder depois que a pessoa levanta do até, mas é para a pessoa. Um filho de Orixala não pode ter azeite

\footnotetext{
${ }^{38}$ Sobre esse ponto, conferir Halloy (2005, p. 157).
} 
no obori, nem no amassi, você pode dar um bicho de pena que seu orixá gosta, mas o obori é para pessoa. Eu já vi pôr o santo para vir comer na hora que corta pro ori, mas aqui em casa não é assim. Que nem painho dizia, ali é o ori e não o santo."

Essa diferença entre a pessoa e o orixá recai sobre a ideia de que as características dos filhos de santo advêm de seu orixá. Mãe Lu, ao falar de um filho de santo que não aceitava ser de Iemanjá, dizia:

Ele não quer ser de Iemanjá, acha que é de Ode. E os filhos de Iemanjá não são divertidos também? Não gostam de brincar? Se todo mundo só pelo que é, pelo jeito, já soubesse de qual santo era filho, para que jogo de búzios então? É uma honra ser filho de Iemanjá. Pode ser que ele fosse, lá no pai de santo dele de outro santo, mas aqui ela que respondeu, ele tem de herança já, a mãe dele não é de iemanja com oya, ele se parece muito com ela, aqui em casa é assim, ela fala mais alto, e toma a frente mesmo, mas ele é de Iemanjá mesmo, eu vejo uma mulher no rosto dele. Mas a pessoa não é o santo...

Essa questão é complexa e merece atenção. A filiação entre uma pessoa e seu orixá pode ser traduzida pelo conceito de herança. A herança, como veremos no quarto capítulo desta tese, pode se atualizar em diferentes momentos e de acordo com os contextos; por exemplo, o reconhecimento de determinados traços físicos ou raciais, ou ainda de algumas tendências comportamentais e traços de personalidade. Mas a herança não é determinante e exclusiva, sempre surge enquanto uma confirmação ${ }^{39}$, e essa sempre depende dos contextos que atualizam essas relações.

A questão então me parece ser menos uma relação de identidade entre o santo e seu filho e mais um processo de individuação. Poderíamos pensar na diferenciação entre ori e orixá em termos de uma "composição" "de forças heterogêneas, e não da modelagem direta de uma sobre a outra. É dizer, tal relação não seria de natureza hilemórfica, de uma matéria inerte sobre a qual se poderia imprimir qualquer forma" (Goldman, 2009).

A diferenciação entre pessoa e orixá me parece ser exemplificada a partir da noção do corpo enquanto matéria. As restrições rituais para a interação com orixás, eguns e espíritos têm na "matéria" o ponto central. Entende-se que as relações sexuais, o uso de bebidas alcóolicas em demasia e toda a sorte de substâncias entorpecentes são impedimentos para a manipulação

\footnotetext{
${ }^{39}$ A confirmação é relacionada a determinadas configurações do jogo de búzios que indica que os orixás aprovam uma oferenda ou uma resposta positiva a uma questão formulada.
} 
dos objetos rituais ou mesmo para a possessão espiritual. Todos esses impedimentos têm no corpo a sua tradução.

Corpo sujo é a principal evitação ritual. Quando uma pessoa mantém relações sexuais, seu corpo está “sujo" para entrar em relação com os orixás. Todas as pessoas que participam de uma obrigação devem abster-se de ter relações sexuais pelo período que varia entre sete dias ou mais, a depender de certos elementos. Se em uma obrigação for sacrificado um boi ou um cágado, por exemplo, o período de resguardo ${ }^{40}$ é de 26 dias. Pai Paulo sempre se queixava do risco de oferecer um animal de grande porte pelo receio de que nem todos os envolvidos fossem capazes de respeitar o resguardo. Considera-se um "mau pai de santo", ou um "mau axogum", aquele sacerdote que não se abstém de ter relações sexuais no período em que seus filhos de santo estão em obrigação. Junior Boto refere-se a isso como uma forma de "vício", a pessoa que não contém seus desejos durante esse período.

Outro aspecto ligado à "matéria" são os usos de substâncias entorpecentes. Nesse caso, costuma-se dizer que os santos abandonam seus filhos quando eles se envolvem com o uso de drogas ou de bebida em demasia, especialmente nos períodos de resguardo, e deixam de baixar neles. Uma pessoa que está de resguardo não deve consumir bebida alcoólica ou mesmo fumar cigarro nesse período.

Há ainda um outro tipo de impedimento ritual, restrito às mulheres: o corpo aberto, uma condição atribuída a uma mulher quando está menstruada. Nesse período ela deve-se abster por completo de qualquer manipulação ritual e não pode receber nem orixás nem espíritos de jurema. A presença no peji nesse caso somente é aceita em caso das obrigações a Orunmila.

Há ainda outro tipo de "corpo aberto". Quando uma pessoa passa por alguma cirurgia ou está muito debilitada fisicamente, é comum referir-se a ela como estando de "corpo aberto". Sendo assim, uma pessoa deve evitar frequentar determinados locais tidos por perigosos, tais como cemitérios, bares, locais com grande movimentação de pessoas. Também não deve participar de obrigações que envolvam "muito sangue" e manter-se distante das obrigações aos eguns. Essa evitação implica tanto no estado da própria pessoa, que com o corpo aberto deve seguir tais restrições, quanto no caso de ter algum parente consanguíneo próximo que se encontre nessa situação.

As evitações rituais são válidas também para o trânsito entre os territórios religiosos, mais especificamente entre candomblé, egum e jurema. É preciso observar o intervalo entre

\footnotetext{
${ }^{40} \mathrm{O}$ resguardo é o tempo posterior as obrigações no qual uma pessoa e comunidade devém abster-se de ter relações sexuais, frenquentar determinados lugares como, hospitais, cemitérios, etc.
} 
essas práticas, sob o risco de "misturar as energias". Essa mistura pode incorrer em efeitos nefastos para uma pessoa. Por exemplo, quando se está de resguardo de uma obrigação para os orixás, não se deve frequentar cerimônias religiosas da jurema e vice-versa. Quando se inicia o filho ou filha de santo, além de manter resguardo de relações sexuais, ingestão de bebidas alcoólicas e de cigarro, também se deve abster de frequentar festas e toques de Jurema. O corpo é novamente acionado como explicação, uma vez que o orixá está muito próximo à pessoa e pode se ofender com a fumaça $a^{41}$. O corpo é o local por onde se manifestam os espíritos e sua presença pode ser nociva ao orixá.

De todo modo, todas essas evitações determinam uma diferenciação do ponto de vista das relações de santos e pessoas; sendo assim, a prática sexual é entendida como a restrição mais forte. É aqui que o contraste se faz mais evidente: entende-se que uma pessoa com a qual se tenha relações sexuais deva se abster de qualquer contato com o conjunto de coisas espirituais do parceiro. Não deve manipular os assentamentos, não pode participar de nenhum dos procedimentos das obrigações para os santos de seus parceiros e, por fim, se a pessoa está "manifestada", não deve entrar em contato físico com sua/seu parceira/o sexual. A única obrigação em que se aceita qualquer tipo de interação momentânea entre parceiros sexuais, atuais ou pregressos, é o oferecimento do peixe no obori. A explicação recorrente é que, como vimos, o obori é uma obrigação para a pessoa e não seu orixá.

Essa regra é válida para parceiros sexuais ou mesmo qualquer pessoa com quem já se tenha tido alguma experiência sexual. Contudo, em alguns casos - em particular na ausência completa de uma pessoa a quem se julgue capaz de fazer o obori -, aceita-se a participação de parceiros, desde que também seja feito no santo, que então poderá soprar o axé no ori da pessoa. Pai Paulo me dizia que seu avô Adão, no final da vida, não confiava em ninguém para fazer seu obori e que era sua avó quem "soprava o axé em sua cabeça".

Pais e mães consanguíneos são igualmente impedidos de "soprar o axé" na cabeça de seus filhos. Mãe Lu relata que seu pai, Malaquias, por ocasião de sua iniciação, "preparou tudo", mas não realizou os atos do obori. Nos casos dessa interdição, pode-se eleger uma pessoa de confiança, mais velha e interna à família de santo, para que esta cumpra o papel de iniciadora. É o que ensinou Mãe Zeza, neta carnal da famosa Ialorixá Lidia Talabi, para a antropóloga Aida Bueno:

/.../Minha avó começou com a Jurema em casa. Seu santo estava na casa do Sr. Artur e Jurema ficava na casa dela. Ali, ela deu as sessões e minha mãe-de-santo - que foi sua primeira filha santo - sentou-se à mesa com ela para receber os espíritos. Das

\footnotetext{
${ }^{41}$ Fumaça é outro termo para se designar o domínio da jurema.
} 
Dores passou muito tempo com minha avó, até que abriu seu terreiro. Como ela era filha do santo mais antiga, ela a colocou como mãe-de-santo minha e de Papai (Manoel do Nascimento Costa). Para nós, que éramos sangue dela, quem fazia o Borí não era minha avó, mas Mãe Das Dores, e era filha de Oxalá (Sarduy, 2014, p. 379).

Mas se o obori permite algum tipo de interação entre parceiros sexuais, o impedimento entre os ascendentes consanguíneos direto é mantido ${ }^{42}$. Aqui, outra metáfora é acionada para falar do corpo na relação entre pais e filhos consanguíneos: a noção de "parentes carnais". Em Recife, é comum as pessoas se referirem aos pais ou filhos consanguíneos como "minha mãe carnal", "meu filho carnal". Essas frases são evocadas para marcar a relação de consanguinidade em relação ao contexto da família de santo. A consanguinidade entre parentes em um terreiro é descrita como "parentes de sangue". Contudo, para se referir aos ascendentes diretos consanguíneos, em geral, usa-se o termo carnal em vez de sangue, ainda que eventualmente possa se falar em termos de mãe ou pai de sangue.

Em ambos os casos, me parece que o complexo ritual de evitações atenta para o risco da proximidade intensiva que o sangue e a carne aludem no processo de extensivação da iniciação, do corte de uma linha em um outro fluxo de relacionamentos, embora esse corte seja sempre parcial, pois as linhas tendem a ligar-se novamente. O corpo é entendido como uma contraparte do espirito, uma dimensão deste e não o seu oposto. Se o axé têm dimensões espirituais que são elas mesmas substâncias, o corpo tambem pode ser pensado como uma analogia do espirito, uma continuidade em outros termos deste.

É o que evidência o ritual do obori, se o corpo e a cabeça são entendidos enquanto ori, a manipulação ritual da contraparte espiritual do orí se dá por meio de uma tigela branca que é tida como uma extensão do corpo espiritual da pessoa. É através dela que uma pessoa alimenta e fortifica seu ori. Diferentemente dos assentamentos dos orixás e da jurema, o vínculo material do ori espiritual é momentâneo, ocorre somente no decorrer do ritual obori. Não há um assentamento de ori que possa ser transmitido a outras pessoas. Uma filha de santo deve sempre ter guardados sua tigela, seu copo e prato brancos utilizados no obori, mas eles não são fruto de nenhuma manipulação fora do ritual. Quando uma pessoa morre, ele deve ser despachado com

\footnotetext{
${ }^{42}$ Edgar Rodrigues Barbosa apresenta uma reflexão sobre essa ocorrência ao comentar uma passagem de Vivaldo da Costa Lima que se aproxima dos casos do Recife: "Mesmo a sucessão dentro da linhagem de sangue, nos casos em que prevalece a interdição de a ialorixá fazer o santo em suas próprias filhase, conta com arranjos complexos em sua relação com o parentesco ritual. Havendo então o incesto, o qual, segundo parece, está longe de ser a regra, 'as obrigações das filhas das mães-de-santo são sempre feitas por ebômins de sua amizade e confiança, de sua própria casa ou a ela associadas por parentesco de sangue ou de santo. Claro que a ialorixá a tudo supervisiona e orienta, mas quem põe a mão na cabeça, quem raspa e pinta, é outra mãe. A iniciação pode ser feita no próprio terreiro ou em terreiro de outra ialorixá"” (Lima, 1998, p. 42). "Trata-se de um caso em que a sucessão pelo sangue exige a aliança com a filiação pelo santo" (Barbosa, 2012, p.114).
} 
outras coisas de uso pessoal da pessoa. Desse modo, o ritual instaura uma descontinuidade entre a dimensão corpórea do ori e sua contraparte espiritual, dado que a manipulação espiritual ocorre nos objetos do ori para depois ser replicados no corpo da pessoa. É disso que se trata a próxima seção.

\section{OBORI}

O obori é a principal obrigação do ciclo de iniciação do candomblé nagô. Meu objetivo ao descrevê-lo é evidenciar a construção das relações de filiação por meio das quais uma pessoa é feita filha de santo. Como veremos com mais detalhe, o ato de alimentar o ori e os orixás são centrais nesse processo, haja vista que se cria o parentesco tanto alimentando a cabeça da pessoa - sua singularidade - quanto fazendo o santo — , duas ações traduzidas pela referência alimentar, ou dar de comer. Ainda que as duas coisas sejam fundamentalmente diferentes para os praticantes do nagô, é por meio desses dois modos relacionais específicos - o ato de alimentar o ori e o de fazer o santo - que se revela como os praticantes do nagô pensam diferentes engajamentos rituais e como coordenam suas ações por meio do parentesco de santo.

O obori sempre é necessariamente precedido por uma obrigação aos eguns. Essa obrigação costuma ser em intenção tanto dos eguns da pessoa que se inicia (seus antepassados familiares) quanto os da família de santo. Embora todas as invocações e atos rituais sejam destinados para os últimos, se a pessoa possui ascendentes diretos falecidos, eles serão enfatizados no momento da obrigação. Retomarei esse ponto no capítulo seguinte.

$\mathrm{Na}$ semana em que se realizam obrigações, o obori costuma ser na quarta ou quintafeira, sempre ao anoitecer. Por vezes, a obrigação aos santos segue imediatamente a sua realização, entrando pela madrugada e finalizando esse conjunto ritual apenas na manhã do dia seguinte. Em obrigações maiores, como feitura ou $\operatorname{deka}^{43}$, de pais e mães de santo ou pessoas com maior destaque, respeita-se um dia para cada obrigação, culminando na festa ao santo aos sábados. Mas isso não é um padrão fixo ou uma regra.

No obori aqui descrito, a obrigação aos eguns foi tida como "bem simples" pelas pessoas do terreiro, constando apenas de bichos de pena e sem cânticos na segunda parte da obrigação. Pai Paulo avisou que a filha de santo não poderia arcar com os custos de uma obrigação grande e que o obori foi uma determinação do jogo, que ela teve de recolher os recursos em pouco

\footnotetext{
${ }^{43}$ Obrigação especial que marca a maioridade de um filho de santo.
} 
menos de uma semana, mas que, de acordo com os merecimentos e fé, ela alcançaria as graças dos santos.

No final da tarde, algumas pessoas da "família de sangue" e amigos da filha de santo chegam para o obori. Eles não são membros de nenhum terreiro, apenas a filha de santo é ligada ao universo do candomblé. Quando chego ao terreiro, encontro Mãe Lu e um filho de santo armando o até, o espaço onde se desenvolvem as principais ações do obori e que consiste basicamente em uma fina esteira de palha coberta por um lençol branco. Ela se estende para a parede, com um lençol branco armado. Serve de apoio para a filha de santo e forma um conjunto branco no centro do barracão, entre o peji e o balé. Sobre a esteira, fica um pequeno travesseiro e, ao lado, um prato branco de porcelana e uma xícara, objetos utilizados exclusivamente pelo iniciante para alimentação e cuidados com grande zelo.

Enquanto montavam o até, Paulinho e Junior organizavam os alimentos que seriam ofertados no obori. Como veremos, a duplicidade é um valor importante na estética nagô. Duas longas fileiras de alimentos são colocadas em cada extremidade do até. Cada fileira de alimentos se inicia com um vaso de flores brancas circundado por um conjunto variado de bebidas (refrigerantes, vinhos, cachaças, cervejas, espumantes, licores) e uma grande quantidade de frutas. Circundam as bebidas produtos alimentícios industrializados, como doces, bolos e bolachas. Há ainda um ou dois pedaços de queijos, além de carnes de porco e boi, e principalmente um peixe - este último, um alimento central no obori, ao lado do inhame.

Mãe Lu leva a filha de santo para um banho de folhas; na volta ela já está vestida com um conjunto de baiana, de rendas pequenas e na cor branca. Ela acompanha a filha de santo para que ocupe seu lugar no centro do até, com as costas apoiada na parede. A filha de santo senta-se com as pernas e mãos estendidas e Mãe Lu coloca um pano branco rendado sobre seus ombros, cobrindo também braços e mãos. Pede, então, a outra filha de santo que acenda as velas.

Em frente à filha de santo, o ori é montado. Uma terrina branca foi lavada em um amassi, e dentro dela, é colocada algumas moedas. Um prato branco cobre essa terrina, sobre ele o conjunto de oito búzios que serão utilizados para consultar o ori no decorrer da cerimônia e algumas folhas de corona. Ao lado do ori, uma vasilha contendo um peixe e um grande inhame. Há ainda um pequeno prato com $o b i^{44}$ e $\operatorname{orog}_{b o}{ }^{45}$ e uma bacia com assadaka (bebida feita com

\footnotetext{
${ }^{44}$ Obi é uma noz-de-cola, seu nome científico é Cola acuminata, podendo ser uma noz dividida em duas ou quarto partes ou mais.

${ }^{45}$ Outra noz-de-cola Garcinia kol, amplamente utilizada nos rituais.
} 
farinha de fubá cozida, dissolvida em água e mel; elemento importante do culto aos eguns). Além desses objetos, uma grande bacia com acaças e acarajés.

A disposição espacial das pessoas no obori determina a ordem hierárquica daqueles que executam o ritual. Pai Paulo senta-se em um pequeno banco de madeira em frente ao ori, Bino e Paulinho, que se sentam logo atrás dele, à direita de seu ombro, serão os padrinhos da filha de santo. Todos estão de frente para a iyawo e de costas para a plateia. Mãe Lu e Bárbara sentam-se em duas cadeiras dispostas ao lado da filha de santo, posicionadas de costas para a parede de frente para o pai de santo e o ori: serão respectivamente a mãe de santo (à direita) e madrinha (à esquerda). A audiência ocupa o espaço ao lado e atrás do pai de santo. A família carnal está à esquerda e os filhos de santo no sentido oposto e à direita. Alguns jovens ogans se posicionam próximos aos padrinhos, sempre atentos a colaborar com alguma atividade solicitada.

Pai Paulo senta-se no pequeno banco com alguma dificuldade. Retira o prato do ori, pega uma quartinha com água, enche a boca com água e assopra sobre o ori e sobre os demais objetos que estão dispostos na frente da filha de santo; mastiga um pouco de pimenta da costa e repete o gesto:

Ori owo!, exclama.

A audiência responde: Ori owo!

Inicia-se uma longa saudação aos eguns do terreiro, aos orixás e ao ori da filha de santo — essa lista é entrecortada pelas saudações aos orixás, aos eguns e ao ori.

Bino corta as duas extremidades do inhame e entrega a Pai Paulo, que as apresenta ao ori e joga: Edi meji!, diz sorrindo e coloca os quatro pedaços no prato. Enquanto isso, Bino entrega a um dos ogans o restante do inhame para que ele o cozinhe. Pai Paulo levanta-se e caminha até a filha de santo, repete o ato de assoprar os axés em seu ori. Mãe Lu exalta: Ori o owo!; e a assistência repete em voz alta, "Ori owo".

Passa-se a entoar uma longa invocação ao ori ${ }^{46}$, sempre entremeando as frases com nomes dos antigos eguns do terreiro e orixás. Bino entrega o obi a Pai Paulo, que toca na borda da bacia, continua as invocações e a devolve a Bino, que caminha sem sandálias sobre o até e toca com ele na cabeça da filha de santo. Bino lhe devolve o obi, ele o corta e entrega um pedaço para Bino, outro a Mãe Lu e um terceiro a Bárbara. Todos o colocam na boca e mastigam. O

\footnotetext{
46 Todas as fórmulas rituais e as invocações foram descritas magistralmente na tese de José Jorge de Carvalho (1984). Há poucas alterações em relação ao conjunto de frases utilizadas, ainda que cada pai de santo o faça a seu modo. Assim, para uma apreciação do conjunto de cânticos e fórmulas rituais expressos nos rituais do nagô, conferir José Jorge de Carvalho (1992).
} 
amargo da noz explicitado pela careta que provoca é acompanhado de risos da plateia. Mãe Lu entrega um pedaço para a filha de santo, que o mastiga também. Bino ajuda Pai Paulo a se levantar. Ele caminha para a esteira (todos que caminham em direção à filha de santo o fazem pelo lado direito da iyawo, à esquerda do pai de santo) e apoia suavemente suas mãos sobre a cabeça da filha de santo, separando seus cabelos ao meio. Pai Paulo abaixa sua cabeça e cospe o obi mascado nesse ponto. Todos saúdam Ori owo! Mãe Lu, Bárbara e, por fim, Bino, fazem o mesmo. A cada ato o ori é saudado.

Pai Paulo retorna ao seu banco e continua a invocar e pedir para o ori da filha de santo. Todos os atos rituais que se seguem ficam, a partir desse momento, a cargo de Bino. Junior Boto agora ocupa o banco de Bino. Bino pega o prato com o peixe e entrega a Pai Paulo, que derrama um pouco da água que se acumulou no prato no ori e no chão à frente do ori. Entrega o prato e a terrina com água a Bino, que os coloca sobre o ori da filha de santo, o prato com a mão direita e a terrina de água com a esquerda. Enquanto realizava esse ato, Pai Paulo cantava a cantiga do peixe e continuava a exaltar o ori, agora com mais intensidade.

Enquanto cantavam, as pessoas se organizaram em fila para pedir pro ori da filha de santo, o que consiste em segurar o peixe e a vasilha com água no ori da filha de santo e desejar sucesso e "coisas boas" para sua vida. A ordem da fila seguia pela hierarquia, pessoas mais velhas (de idade e de santo) iam na frente das mais novas. Alguns convidados e parentes da filha de santo foram encorajados a fazer o mesmo. Por fim, a própria filha de santo faz o mesmo gesto sustentando a bacia e o peixe em seu ori. Esse é um momento de bastante descontração. Em um dos oboris de Pai Guara que acompanhei, por exemplo, as pessoas se divertiam com o tamanho do peixe que o pai de santo comprara, um peixe enorme, com mais de 30 quilos, e aproveitavam para fazer piadas à antiga mãe de santo, dizendo que ela teria de sustentar o peixe no ori dele durante toda a obrigação.

Bino entrega o prato com peixe a Paulinho, que começa a cortar o peixe em pedaços determinados (cabeça, rabo e barbatanas). Junior Boto, com ajuda de um dos ogans, começa o corte das carnes de boi e porco, fazendo-o em pequenos pedaços. Após o corte, as carnes e os peixes foram temperados com dendê, mel e sal. A combinação desses três alimentos é uma das características do candomblé nagô; eles não são apenas oferecidos no obori, mas também nas obrigações de axexe e Orunmila. Retorno a isso em mais detalhes no próximo capítulo.

Uma parte das carnes é entregue a outro ogan, que irá cozinhá-la. Pai Paulo pega com cuidado o prato com os pedaços de peixe, derrama novamente um pouco do líquido no chão e em seguida dentro do ori. Retira e coloca-os dentro da tigela do ori. Bino, que fica o tempo todo 
em pé ao lado do pai de santo, pega o rabo do peixe e passa para Mãe Lu, que toca com a base do pedaço no ori da filha de santo, a qual, em seguida, deve tocar o pedaço com a ponta da língua e assoprar para os lados; Mãe Lu entrega o pedaço a Bárbara, que repete o procedimento em outras partes significativas do corpo da filha de santo (peito, costas, braços, palmas das mãos e pés), entrega para Bino o rabo do peixe, e ele coloca dentro do ori. Repetiu-se o mesmo procedimento com os pedaços de carne de boi e de porco. A cada etapa, uma variação com o nome dos elementos era incluída nas saudações. Bino retira o caldo que sobrou nos pratos e despeja no ori.

Paulinho entrega duas galinhas de granja para Bino, que as segura pelas patas e passa o corpo delas, com cuidado, no contorno do corpo da filha de santo, começando por seu ori e terminando nos pés. Entrega as galinhas para Pai Paulo, que as segura gentilmente em direção ao solo, oferecendo-as ao ori da filha de santo. Após o abate, os mesmos lugares foram tocados com o sangue das galinhas. A mãe de santo fez o ato cerimonial no ori e na boca, e a madrinha, no resto do corpo. Cada lugar do corpo foi coberto com penas das galinhas. A filha de santo permanece com os olhos semicerrados e estáticos, olhando para o horizonte, por vezes para o próprio ori.

O mesmo ocorreu no ori: seu interior foi coberto com penas dos peitos e das costas, como um cobertor que cobrisse o interior da bacia, penas das asas foram dispostas no interior da bacia formando um círculo. Bino entregou algumas penas da asa e estas foram colocadas entre as orelhas e entre os dedos do pé da filha de santo. Mãe Lu pediu à mãe carnal da filha de santo um pequeno embrulho que esta estava segurando durante todo o obori. Uma tiara de pano, no formato de uma meia lua, toda branca e decorada com búzios e rendas. É o ataquete, ele foi amarrado no ori da filha de santo e mais algumas penas cobriram o centro da cabeça dela.

Nesse momento, Pai Paulo ajoelhou-se sobre suas sandálias e apoiou os antebraços no banquinho. À exceção de Mãe Lu, todos se ajoelharam e iniciaram uma sequência de cânticos a Orunmilá. O coro se intensificava. Um filho de santo me pergunta em voz baixa se eu já tinha visto um ritual tão bonito. E diz: "Orunmilá é nosso, do nagô, nosso obori é bem demorado, não é rápido igual ao do jeje...".

Por fim, ainda ajoelhados, todos os presentes repetiam uma pequena execução ritual: a cada vez que as palavras de orio owo, ori ege, ori ami, ori axó eram pronunciadas, as pessoas abriam seus braços e faziam o movimento de um círculo que se iniciava do alto das cabeças e terminava na altura dos umbigos, e respondiam: Ori Alafia, Ori Alafia, Ori Alafia. 
Bino pega o prato branco que cobria o ori e recolhe os oito búzios que estavam em cima dele. Com as duas mãos, esfrega os búzios apontando para o ori da filha de santo e joga, mostra para Pai Paulo. Pai Paulo murmura Ogunda e Bino joga novamente. Ejimeji! "Axé” diz Pai Paulo sorrindo e dizendo: "tudo bem, as sortes virão ao encontro da vida de acordo com o merecimento. Ori owo!"

As obrigações do nagô respeitam um arranjo característico no decurso da ação ritual. A obrigação sempre ocorre em dois momentos. O corte dos animais e o Iyanlé (etapa ritual em que os alimentos cozidos e parte dos animais oeferecidos são colocados nos assentamentos) e em cada uma podemos ver uma replicação interna desses mesmos procedimentos, antecipando o fluxo maior de eventos de cada etapa. Por exemplo, os cortes do inhame, do obi e do orogbo que abrem o ritual antecipam os cortes dos animais, assim como distintos métodos de divinação abrem e fecham cada momento ritual e seus interlúdios, o jogo de oito búzios, sempre realizado na abertura, o método divinatório com as caídas do inhame e do obi e, por fim, o jogo de oito búzios ao final da primeira etapa.

Todos os alimentos que devem ser preparados e ingeridos no primeiro ato são temperados crus com azeite, sal e mel. Esses mesmos elementos são utilizados ao final dos sacrifícios e devem novamente temperar as comidas e os axés quando refogados e preparados para a etapa do Iyanlé.

Com todas as comidas do ori preparadas, cada prato é novamente preenchido com aqueles alimentos cozidos que marcaram a etapa ritual anterior: inhame, peixe, carne de boi, carne de porco, os axés das galinhas e suas vísceras, peito, asas e patas. Todos os pratos são colocados no chão. A depender da temperatura ambiente, um ventilador é ligado para resfriálos mais rápido. O relógio marca 21 h e Pai Paulo toca uma pequena sineta para dar início à segunda parte.

Pai Paulo pega o prato com peixe e passa a Bino, que o coloca na frente da filha de santo. Mãe Lu avisa que ela deve tocar o prato com a ponta dos dedos e depois tocar sua própria cabeça. Ori owo!, exclama a plateia. O mesmo movimento é feito com os outros pratos.

Paulinho e Junior pegam os diversos pares das garrafas de bebidas e vão passando para Bino. A filha de santo repete o movimento de tocá-las com as pontas dos dedos e levá-los à cabeça. Por fim, restaram apenas as comidas industrializadas (bolos, queijos e doces), que recebem o mesmo tratamento.

Pai Paulo retira então um acaça embrulhado em folha de mamona, um pequeno bolo de farinha de milho amarelo, semelhante a uma pamonha. Ele corta o acaça e coloca no chão em 
frente ao ori. Outro acaça é desembrulhado e desmembrado no interior do ori. Um terceiro é aberto e modelado em forma de uma bola, Pai Paulo faz um furo com o polegar e entrega a Bino. É o Ika. Na primeira parte, vimos que o ori come em dois recipientes distintos, a própria cabeça da filha de santo e uma terrina branca. Nessa etapa, são acrescidos mais dois recipientes que servem para essa alimentação, o Ika e o prato branco no qual a filha de santo deverá fazer suas refeições enquanto estiver "de quarto".

Paulinho e Junior começam a desfiar os pedaços das carnes, retirando-as dos ossos até que estes estejam completamente "limpos". O primeiro prato é o peixe; a cabeça e o rabo são colocados dentro do ori, a cabeça em uma ponta e o rabo na extremidade oposta. Um pedaço do peixe é colocado sobre o acaça que está no chão, outra no ori e outra no prato da filha de santo. Ela deverá comer a comida que está no interior do prato.

O caldo dos alimentos cozidos é despejado com muito cuidado no acaça que está em frente ao ori, no interior do ori, no prato e no Ika. O restante continua no prato que é colocado no chão e todos os presentes poderão se alimentar dele ao final do obori. Após realizar essa sequência com os outros alimentos, Bino pega o Ika das mãos de Pai Paulo e entrega para Mãe $\mathrm{Lu}$, que o coloca sobre o ori da filha de santo.

Pai Paulo agora abre, uma a uma, as garrafas de bebida. Derrama um tanto sobre o acaça que está no chão, um pouco no ori e outro em um copo que a mãe de santo segura em suas mãos nesse momento. A última garrafa é a do espumante, todos aguardam a rolha estourar - o que demora um pouco na mão de Bino, que estava escorregadia. Ori owo!, gritam todos quando a rolha estoura.

Algumas frutas são dispostas e pedaços dos bolos e queijos são colocados dentro do ori, por fim, os doces e bombons. Alguns são jogados para a assistência. As crianças se divertem tentando pegar alguns deles nesse momento.

No final dessa etapa, Mãe Lu retira o Ika que estava sobre a cabeça da filha de santo e coloca em suas mãos; ela deverá comê-lo e depois pegar o copo com as bebidas para beber seu conteúdo. Por fim, um copo de assadaka deverá ser bebido por completo. As pessoas da assistência abaixam sua cabeça nesse momento. Mãe Lu retira as penas que estavam em seus pés e Bino as coloca no ori. O mesmo foi feito com as penas que estavam no ori da filha de santo.

Novamente a sequência de cânticos a Orunmila é entoada. Todos retomam a posição de se ajoelhar e se prostrar nesse canto. Um momento de pura deferência. Quando se encerram os cânticos, ainda de joelhos, retornam a saudar o ori. Bino joga os búzios no prato branco de 
porcelana e mostra o resultado a Pai Paulo: Ogunda. Joga novamente e Edi Meji! Todos gritam ori owo!

Nesse momento, Pai Paulo levanta-se do banco e começa a balançar a sineta com força enquanto as pessoas cantam a toada "e barika". Pai Paulo se anima e começa a invocar os santos da filha de santo. Sua voz se eleva, ele clama pelos seus antepassados. Mãe Lu e Bárbara ajudam a filha de santo a se levantar do até. Ele a chama pelo nome, por três vezes. Ela se levanta e dança em direção ao pai de santo. Todos na assistência estão em pé, batendo palmas no ritmo do agbe (cabaça envolta em uma malha de contas) que Junior Boto está tocando. Mais palmas.

Mãe Lu e a madrinha levam a filha de santo para ver a lua e as estrelas, pedem para que ela faça um desejo. Retornando ao salão, encaminham agora a filha de santo ao peji, para saudar Iemanjá e seus santos. Geralmente, quando uma pessoa já iniciada vai ao peji, ela saúda Iemanjá, outros orixás da casa e seu próprio santo em seu assentamento. Como a filha de santo não havia assentado seus santos, ela bate cabeça aos assentamentos dos orixás da casa. Após saudar os santos no peji, Mãe Lu conduz a filha de santo para bater cabeça para seus iniciadores: Pai Paulo e Mãe Lu, Bino, Paulinho, Junior Boto e Bárbara. Esse ato finaliza o obori e sinaliza agora o respeito e deferência que a filha de santo terá para com essas pessoas pelo resto de sua vida.

Terminado o obori, a família carnal é convidada a cumprimentar a filha de santo. Se o obori for para uma pessoa já iniciada ou muita antiga no santo, seus filhos de santo ou irmãos de santo mais novos deverão fazer uma fila para cumprimentá-la.

Os rituais marcam a feitura da filha de santo no decurso de sua vida em um terreiro de candomblé. É preciso estar atento para o conjunto de ações rituais, não apenas para integralizálos em um estilo ritual específico, mas para visualizar o encadeamento de ações que resultam em um novo fluxo de relacionamentos das pessoas envolvidas.

Como vimos, o ori é a multivalência de coisas ${ }^{47}$ : simultaneamente é uma vasilha de porcelana branca e algumas moedas, a cabeça física, um iká com alimentos, a vontade da pessoa e seus pensamentos, um anjo da guarda, seu espírito. No candomblé, como se sabe, toda ação ritual consiste em aumentar, expandir o axé, a energia vital, para a melhor existência das coisas. No obori, as pessoas absorvem o axé das comidas que comem, dos animais e do sangue. Tudo deve ser ingerido.

\footnotetext{
${ }^{47}$ É preciso sinalizar que a multiplicidade do ori não consiste apenas em seu aspecto tangível, como apontam Carvalho(1984) e Halloy(2005), mas igualmente em seu aspecto intangível, sendo sempre referenciado como alma, espírito, anjo da guarda, vontade, pensamento, desejo.
} 
Mas essa absorção de forças não ocorre como mera disposição da pessoa, o axé não vem do nada. Ele é recebido de uma divindade, de um espírito e principalmente de outra pessoa ou por meio dela. O pai e a mãe de santo não são percebidos como meros mediadores, mas como canalizadores desse fluxo. $\mathrm{O}$ axé circula necessariamente por outra pessoa, ou um conjunto de pessoas. Temos, portanto, a primeira analogia: quem alimenta e fortifica seu ori é seu pai e sua mãe de santo - as pessoas que os auxiliam seriam seus padrinhos e madrinhas, pais e mães menores que colaboram, mas não dirigem essas ações rituais. Nesse sentido, a ação ritual conduzida pelo pai de santo não é mais importante do que a conduzida pela mãe de santo. São atividades complementares, mas de igual valor aos olhos dos praticantes do nagô. Mãe Lu, sobre isso, me ensinou:

"O homem não é mais importante do que a mulher. Todo mundo precisa de um pai e de uma mãe. Não é a mãe que traz ao mundo? É igual nessa hora, o homem é quem pode cortar os animais, mas é a mãe de santo quem coloca o axé, um homem não coloca o axé, o axé é da mãe de santo, da mulher, são sempre os dois!"

Outra possibilidade é alguém possuir como padrinho ou madrinha uma divindade ou egum. Como vimos na fala de Pai Paulo, seu pai de santo foi um egum. Isso revela tanto sua profunda relação com o mundo dos eguns quanto o caráter excepcional de sua iniciação. Contudo, esse não é um caso raro no universo nagô. Mãe Lu conta que seu padrinho foi Orixalá e não uma pessoa.

Durante minha pesquisa de campo, vivenciei ainda mais uma situação em que a madrinha da filha de santo não era uma pessoa, já que uma divindade reclamou esse lugar. Um outro caso foi o dos próprios netos de Mãe Lu, que tiveram como madrinha de santo a Oxum de sua avó. Nesse caso, a usual madrinha da casa, Bárbara, como mãe carnal dos meninos, não poderia ser a madrinha ou mãe de santo - no nagô, a geração imediata está impedida de ser pai ou mãe de santo. Desse modo, a madrinha dos meninos seria a tia avó (MZ) dos meninos, Tia Zite, que é de Oxum. Esse era o arranjo até pouco antes da obrigação, quando um imprevisto acarretou na ausência de Zite na obrigação. Pai Paulo foi ao jogo de búzios e Oxum respondeu que ela seria a madrinha dos netos de Mãe Lu. Novamente, esses são casos excepcionais, mas não incomuns.

Como vimos, pai e mãe de santos, padrinhos e madrinhas, realizam operações rituais distintas e complementares no obori. Os homens manipulam os objetos rituais ligados ao ori enquanto tigela. As mulheres manipulam e cuidam dos atos rituais ligados ao ori enquanto 
corpo. O único momento em que realizam os mesmos atos é ao assoprarem o axé na cabeça da filha de santo e quando abrem as curas no corpo da iniciada. Nos momentos seguintes, seguem separados e realizando atividades específicas. Os homens cortando os animais e as comidas e as mulheres colocando-os em contato com o corpo da pessoa para alimentá-lo.

Esses pequenos pais e mães duplicados podem eventualmente substituir os primeiros, seja no decurso ritual de uma obrigação específica ou na ausência dos primeiros em obrigações futuras. O que determina alguém como pai e mãe é sempre o ato de "assoprar o axé na cabeça" (obori) e botar a mão na cabeça (proceder com as curas, cortes), termos que denotam a mesma coisa; aquele que mastiga os axés e mistura com a sua saliva e a coloca sobre o ori de alguém. Desse modo, quando um pai ou mãe de santo se ausenta, um padrinho ou madrinha poderá substituí-lo, mas é consenso que aquele que fez o ato pela primeira vez se fixa como principal, e nunca deixará de sê-lo, mesmo após sua morte.

Isso implica em situações muitas vezes dramáticas para as pessoas do culto, pois é comum que, à medida que vão envelhecendo, julguem não ser possível encontrar outras pessoas preparadas o suficiente para soprar o axé em seu ori. Essa situação leva a intensos debates por parte das comunidades, dado que uma pessoa precisa estar forte para poder fazer o obori e as obrigações de outras, e um pai ou mãe de santo que não realiza suas renovações anualmente pode vir a se enfraquecer na medida em que assopra no ori de seus filhos de santo, mas não se fortifica para tanto.

Junior Boto me disse algumas vezes sobre a dificuldade que passava para conseguir preparar e organizar suas obrigações anuais, seus oboris, para poder ajudar seus filhos de santo corretamente. "Como posso passar para uma pessoa aquilo que eu não fiz?". Boto é uma das pessoas mais ciosas em fazer suas renovações anuais, em especial seus oboris. Certa vez pude acompanhar uma conversa em que ele e um jovem ogan do Sítio de Pai Adão debatiam essa questão: o jovem rapaz contou que estava se preparando para realizar o obori naquele ano, mas que sua tia havia dito para deixar para o outro ano, argumentando que ele já havia realizado o obori no ano anterior. Boto olhou para mim visivelmente contrariado e disse:

"Não existe isso não. Você está o tempo todo ajudando seu tio (Manuel Papai) nas obrigações dos clientes, levando ebó. Tem que estar sempre com o ori reforçado. Uma pessoa, um pai de santo, mãe de santo, tem que estar sempre com o ori reforçado, ele que sustenta a pessoa, a força dela. Veja Guara, todo ano faz o obori, tem muito filho de santo, então tem que se fortalecer. Ainda mais quando se atende muita gente, muito cliente, porque o cliente é pior, uma hora ele está numa casa, em outra em outra, vai pulando de galho em galho, 
você não sabe por onde ele esteve o que ele passou, como você sabe com os filhos de santo, que pelo menos você que está sempre cuidando. O ori é sua força, eu quando não faço todo ano, fico agoniado. Então se você tem a oportunidade, se está com o dinheiro, faça o obori esse ano. Orixala e Iemanjá vão te ajudar."

Como vimos, a relação entre iniciadores e iniciados é traduzida em termos de força. “Cuidar é uma palavra pequena, mas que tem muita força!”, me traduziu Junior Boto sobre sua relação com seus filhos de santo. "Ser um zelador, ter carinho e cuidado com os orixás, pai de santo tem que ter isso, que minha mão seja boa para a pessoa". Há ainda certo consenso de que a ligação entre uma filha de santo e um de seus iniciadores é mais forte do que com seus padrinhos e madrinhas. Esses, todavia, são mais fortes do que um novo pai ou mãe de santo, que não teria participado da iniciação, nem de suas renovações. Uma elaboração de Bino a esse respeito permite ilustrar o ponto:

“Olavo, eu não acredito em tirar a mão de ninguém da cabeça. Quando morre alguém, a gente pode completar, ou renovar, o axé, mas tirar a mão não, nunca, para ter um outro pai de santo, só se você nascer de novo!"

Diversas vezes em meu campo percebi essa relutância em escolher outra pessoa para se fazer um obori. Esse arranjo tende a ocorrer quando uma pessoa muda de casa de santo, já que, na maioria dos casos em que tal situação ocorreu, a filha ou filho de santo buscava alguém da própria "família". No caso de ruptura com um de seus iniciadores (nesse caso, evidencia-se a distinção de santo e sangue, dado que impreterivelmente era alguém da família de santo, caso um filho de santo, ou da própria família de sangue, quando eram pessoas da família consanguínea do terreiro), pode-se optar pela substituição do pai de santo pelo padrinho ou a mãe de santo pela madrinha. Como nos terreiros é comum que a pessoa escolha como seus iniciadores pessoas que não são vinculadas necessariamente à mesma casa, esse segundo arranjo costuma ser mais frequente.

Contudo, a especificidade do obori torna essa condição da confiança e da relação entre pais e mães e seus filhos de santo mais evidente. É possível que outra pessoa "corte" para o seu santo sem que essa se torne seu pai de santo. Ou, ainda, que a própria pessoa, quando esta já é um sacerdote e tem sua própria casa, corte para seu próprio orixá. Mas nunca vi - e considero que essa hipótese sequer pode ser formulada no nagô - alguém que tenha realizado o seu próprio obori. 
Ouvi muitas vezes preocupação por parte da família do terreiro quando do falecimento da geração acima dos descendentes. Nesses casos, as afirmações eram sempre em tom grave e peremptórias: “quando meu tio falecer, eu não faço mais obori”. Depois da morte de Pai Paulo, muitos diziam que só cuidariam do santo e que não saberiam mais quando, como e principalmente com quem fariam seu obori ${ }^{48}$.

Um filho de santo, após o falecimento de Pai Paulo, dizia que não teria mais pai de santo e pediu para que somente Mãe Lu realizasse seu obori. Mãe Lu ficou muito contrariada com a proposta, uma vez que, em seu entendimento, ninguém é feito só com uma mãe ou só com um pai: "é preciso os dois pra você nascer, a mesma coisa no obori, tem que ter os dois, um pai e uma mãe, você pode não considerar aquele como seu 'pai', mas tem que ter alguém ali cumprindo aquele papel, naquele lugar. Quem vai invocar? Quem vai cortar? Fulano diz que é feito no santo, mas ainda não entendeu nada!”.

Pai Paulo mesmo julgava que, com a morte do tio, não conseguiria encontrar ninguém habilitado para fazer suas renovações. Suas opções eram poucas em Recife, já que muitos pais de santo mais antigos do que ele já tinham falecido.

Pouco antes de falecer, na última obrigação de Iemanjá, Pai Paulo fez seu obori após muito tempo. Nos últimos anos, seus irmãos recorriam a ele para que fizesse seus oboris, mas ele mesmo havia deixado de fazer os seus. Nessa obrigação ele consultou o jogo e decidiu realizar seu obori. Quem “cuspiu o axé” em sua cabeça foi Mãe Lu e tia Zite. Seu sobrinho Guara e seu irmão Cicinho realizaram as sequências rituais.

O obori também é entendido como comunhão de todos do terreiro com a nova ou o novo filho de santo. Não só os que estão participando diretamente do decurso ritual devem comer das comidas que são oferecidas ao ori da pessoa, mas todos os presentes. O obori de uma pessoa é uma obrigação muito concorrida entre os membros do nagô. Embora não tenha o mesmo grau de preparação de um toque, as pessoas se esmeram em comparecer com roupas que julgam apropriadas para o evento repleto de formalismo.

No obori de grandes líderes, não somente pais ou mães de santo, mas, por exemplo, de um axogum experiente ou uma ebame $^{49}$ que tenha muitos filhos de santo, espera-se que todos

\footnotetext{
${ }^{48}$ Essa preocupação foi relatada por Arnaud Halloy em um depoimento de Tia Zite: "Zite expressou 'Se Paulo (seu atual pai-de-santo) vier a morrer, não farei mais obori! Eu só dou minha cabeça a Paulo Bráz Felipe da Costa, meu irmão, filho de Malaquías. Eu continuarei a fazer obrigações para o meu santo, mas não vou mais fazer obori. Apenas Paulo ‘coloca a mão’ na minha cabeça!” (Halloy, 2005, p.249), o que acabou revelando-se como uma triste profecia.

${ }^{49}$ Do ioruba Egbon $m i$ "meu irmão mais velho", no ioruba não há flexão de gênero para o termo, mas no Recife há uma flexão derivada dessa palavra, usa-se em geral ebomi para homens e ebami para mulheres. Um caso criativo de uma designação de gênero não existente no contexto original.
} 
os seus filhos ou filhas de santo, bem como afilhados, estejam presentes para "comungar" com essa pessoa. Além da presença física, espera-se que os filhos cheguem junto, ou seja, que contribuam com alguma quantia em dinheiro para ajudar nos custos dessa cerimônia. Esse dinheiro, além de cobrir as despesas da cerimônia, é cotizado para comprar o lanche e bebidas para todos os presentes na obrigação. Possivelmente, as pessoas que trabalharam durante a obrigação receberão um "agrado" pelo seu serviço, também com o dinheiro proveniente dessa ajuda dos filhos e filhas de santo. Entretanto, espera-se que a pessoa que está realizando o obori custeie a maioria dos gastos e entende-se que essa "ajuda" é um complemento desse dinheiro.

Como vimos na introdução deste capítulo, nenhum filho de santo possui apenas um pai ou uma mãe de santo, como em outras nações de candomblé. Trata-se sempre de um pai e uma mãe de santo e, ao menos, um padrinho e uma madrinha. Contudo, essa composição não é estruturada de acordo com cargos preestabelecidos de uma casa. Uma série de fatores contam na hora de escolher cada um deles. Pode-se se filiar a uma casa que tenha uma mãe de santo à frente e o pai de santo ser de outro terreiro. Pode-se ter o pai e a mãe de um mesmo terreiro, mas escolher como padrinhos pessoas de outros terreiros, ou cada um de um terreiro distinto e até mesmo de nações distintas. Nesse caso, entende-se que a pessoa carrega um pouco do axé dessas pessoas e pode até mesmo incorporar em suas obrigações elementos de outras nações, uma vez que ter um ascendente de outra nação condicionaria isso. Deve-se destacar, contudo, que essa variação é mais aceita dentro do conjunto de ações rituais próprias ao obori, se comparadas a outros ciclos rituais do nagô, como obrigação para os santos ou eguns (ponto que descreverei em outros capítulos).

Como veremos, os acréscimos de tecnologias rituais advindos de outras nações, outros territórios religiosos, como a jurema, espiritismo e mesmo o catolicismo, é prática comum nos terreiros do Recife. Podemos traduzi-los como experimentos feitos pelos pais e mães de santo diante de situações e eventos que surgem no dia a dia. Como em toda experimentação, essas novas práticas estão sujeitas ao jugo de sua eficácia - sem determinar, como poder-se-ia pensar, a correção de sua origem em relação ao ponto de partida.

Essas experimentações envolvem sempre riscos, os quais os praticantes buscam diminuir com o auxílio do jogo de búzios, intuição e objetivando estes a partir do plano de fundo de suas práticas convencionais. Nesse caso, a adoção do sacudimento, tido como um ritual jeje, é aceito por ser incorporado como mais uma técnica de limpeza e ajuste da pessoa que viria a fortalecer os filhos de santo e contribuir para o obori nagô. Pode-se dizer que o próprio complexo ritual do obori, ao ser entendido como um ritual da pessoa e não do orixá, é 
mais maleável ao incremento de outras práticas rituais. Como me explicou Bino, seria um acréscimo ao que eles já faziam. Tais procedimentos não se apresentam, necessariamente, como uma novidade e, como veremos a seguir, no nagô o próprio complexo ritual da feitura de uma pessoa envolve, ao longo do tempo, acréscimos e experimentações por parte dos iniciadores, e tais experimentações são sempre trazidas à tona quando as pessoas rememoram esses antigos líderes.

\section{LAVAR CABECGA}

Lavar a cabeça é tido pelos praticantes do nagô como o principal compromisso de uma pessoa durante sua iniciação. É nesse ato que uma pessoa passa a ser efetivamente uma filha de santo e igualmente alguém passa ser considerado plenamente um pai ou mãe de santo. Como me disse certa vez uma antiga mãe de santo:

"Sem ter filho de santo você não é um zelador, você tem seus santos e cuida deles, só é pai ou mãe de santo quando você tem filhos. O povo vem aqui nas festas e quer ser tratado como pai de santo, sem ter tempo, casa e filho de santo, no máximo é um ebomi, um axogum, mas pai de santo não é!"

Em geral, o obori e a lavagem de cabeça são realizados em conjunto, e quem já passou por esse ritual é tido como um membro do culto. É com este ritual que a pessoa passa ter seu santo assentado e passa a poder (e dever) renovar suas obrigações anualmente. Desse modo, só se considera plenamente iniciado quem tenha, além do obori feito, a cabeça lavada, o santo assentado e suas obrigações devidamente renovadas. Além disso, espera-se que alguém que "entrou de quarto" para suas obrigações passe por esse conjunto ritual e o conclua com a "saída de quarto", a festa para seu orixá. Contudo, a festa pode não ocorrer, o que não implica em uma deficiência para a sequência ritual, já que não é tida como uma etapa exclusiva para que uma pessoa possa ser considerada como "um iniciado". Como notou José Jorge de Carvalho, "há diferentes graus de participação no culto mesmo para os estranhos, e também diferentes graus de iniciação para os membros" (Carvalho, 1984, p. 204).

Diversas vezes ouvi em campo, nas conversas entre meus amigos em intervalos das obrigações ou mesmo no dia a dia, que o momento de maior importância na feitura era a lavagem de cabeça. Além de central, tudo indica que se trata de um momento de bastante força. Marcio sempre dizia que a única vez que Ogum quase o pegou foi quando Pai Paulo estava lavando sua cabeça. 
"Ali eu me tremi todo, senti Ogum mesmo, mas não virei, sai de quarto de iyawo, fiz tudo, mas Ogum até agora não me pegou mais. Mas ali, quando Tio Paulo estava lavando minha cabeça, eu senti. Tremia forte mesmo, o braço, o corpo. Tio Paulo invocou e cantou, mas foi isso. Mainha era assim também, o santo pra pegar ela era difícil, e quando Oya chegava, ela saía correndo para o portão, não queria pegar santo...”

Outras pessoas narram a emoção que sentiram quando um filho ou filha virou no santo pela primeira vez no momento da lavagem de cabeça. É o caso de Nina, filha de santo de Juninho e Tia Zite.

"Eu já estava com tudo pronto para dar minha renovação, os bichos de Xangô comprados, de férias no serviço, quando fui para casa de Mãe Zite. Depois de terminar [a obrigação do Balé], meu filho ficou com muita febre, Mãe Zite mandou comprar remédio e nada da febre baixar. E eu pensando, 'meu Deus, o que vou fazer? Como vou entrar de quarto com o menino assim?'. E ele não melhorava. Eu falei que queria sair, aí Juninho jogou e disse que Xangô queria que ele entrasse de quarto também. 'Meu Deus, e agora?' E dinheiro para fazer essa obrigação, eu não tinha mais. Falei então que era para dar obrigação para ele e eu dava depois. Xangô não aceitou, tinha que ser os dois juntos. E eu preocupada. Aí no outro dia dividimos as coisas para fazer o obori. Um falou que ajudava, outro fez a roupa pra ele. No dia de lavar a cabeça, mais uma surpresa, Xangô pegou ele. Foi aquela emoção, todo mundo chorando, ele pequenininho e Xangô veio forte, agora tinha que fazer uma roupa para Xangô também. Luiz falou pra mim que a roupa de Xangô ele dava. No dia da saída, foi uma surpresa ninguém acreditava que ele estava saindo de quarto. Foi tanta foto, tanta foto, que Xangô foi embora, se assustou, nunca mais ele veio. Acho que foi pelos flashes das fotos, foi só aquele dia."

O momento do nascimento de um santo, como algumas pessoas se referem ao ato de lavar a cabeça e assentar um santo, é cercado de atenção e cuidado. Entende-se que nesse momento o vínculo entre o orixá e o iniciado é frágil e qualquer interferência externa pode ser prejudicial. Junior Boto sempre se refere ao orixá como "um filho recém-nascido": "Olavo, o Orixá é um bebê, o que você dá pra ele, ele aceita, por isso devemos ter todo o cuidado, porque se você criar ele de um jeito, quando ele nascer, ele vai estranhar quando mudar, e pode ir embora, pode não ajudar mais". 
Assustar o santo é um dos maiores temores expressos por meus amigos, mais do que “zangar" ou desobedecer a um orixá - fatos que por si só expõem a sanções perigosas ou castigos. Assim, o delicado ato de invocar um santo no momento da lavagem de cabeça envolve o cuidado em trazer aquele santo para a pessoa, e a felicidade que os presentes exprimem quando isso ocorre - que em parte garante o "aceite do santo" pela obrigação realizada e os benefícios garantidos para o filho - é um sinal disso. Como essa presença é ainda muito frágil, as pessoas tomam o máximo de cuidado para o "santo não se assustar". O caso citado acima, em que Xangô se assustou, é um dos vários de pessoas que deixaram de receber seus santos em decorrência de algum desarranjo. Esse cuidado também não passou despercebido por José Jorge de Carvalho, como demonstra esse trecho de sua etnografia:

\begin{abstract}
"Sempre que fazemos alguma coisa com a pedra - lavando-a, por exemplo - estamos estabelecendo um elo entre a natureza e o ser humano. Eu tomo essa pedra lá, no momento da lavagem, no momento do batismo. Eu vou lá, agarro essa pedra e coloco no meio da sua cabeça. Eu canto, e enquanto todo mundo está respondendo, eu, sozinho, 'mentalizo' (concentro a mente). Ninguém está comigo naquele momento; a responsabilidade é minha, sozinho. Então eu canto e muitas vezes até tento desviar a atenção das pessoas, para que elas não fixem os olhos no que estou fazendo. A maioria das pessoas não percebe que estou me concentrando sozinho. Às vezes eu olho para um lugar para distrair as pessoas ou dizer algo apontando em qualquer direção, e as pessoas seguem o que eu faço, de modo que por um segundo eu estou sozinho fixando meus olhos na pedra e na cabeça. Nesse momento: as crianças não devem chorar, nenhum grito é permitido, nenhum ruído, caso contrário, a origem pode ficar assustada, perturbada. E se o orișa é assustado, pode ser o desfazer do que você está fazendo, porque essa pessoa pode ficar traumatizada pelo resto da vida de seu santo. Acontece em um dentre cem casos, mas isso pode acontecer e é uma situação muito difícil: a origem uma vez assustada, a pessoa não a receberá mais" (Carvalho, 1984, p. 336).
\end{abstract}

Pai Paulo sempre dizia que "mais vale uma lavagem de cabeça de antigamente, que um iyawo completo de hoje em dia". Nesse caso, ele faz referência tanto ao poder e força dos antigos sacerdotes, quanto ao fato de que no passado muitas pessoas apenas lavavam suas cabeças e já eram iniciadas, como notou a antropóloga Aida Ester Bueno Sarduy:

É uma cerimônia anterior à 'feituría de santo', que para muitas pessoas será a única cerimônia que eles receberão dentro do santo. Hoje, muitas pessoas no Candomblé acreditam e afirmam que uma cerimônia de lavagem da cabeça feita pelos grandes pais e pelas mães de santo do passado, tem muito mais valor do que uma feituria daqueles feitos hoje (Sarduy, 2014, p. 247).

O complexo ritual da iniciação do nagô, quando mirado de uma perspectiva histórica, registra os diversos acréscimos que essa obrigação recebeu ao longo do tempo ${ }^{50}$. Essas pessoas

\footnotetext{
${ }^{50}$ José Jorge de carvalho relata pessoas com alta hierarquia nos terreiros e que só tinham a cabeça lavada (cf, Carvalho, 1984; 1987). Sobre isso, Waldenir Araujo traz informações semelhantes: "Segundo alguns informantes
} 
comentam ainda que antigamente o nagô não raspava as iyawos, era feito apenas o "coroamento" da pessoa, como me confidenciou um filho de santo membro de uma família de santo antiga dos candomblés do Recife: “antigamente não raspava, isso foi mais recentemente, fazia o coroamento da pessoa, lavava a cabeça, fazia o fundamento e já estava pronto. Pergunta se fulano era raspado, ou Ciclano. E não eram excelentes pais de santo? Não tinha isso de raspar...". Algo parecido foi relatado pelo velho senhor Walfrido, atualmente com mais de 104 anos, para a antropóloga Sarduy:

-Você é o axogún mais antigo da casa?

-Ogã.

-Há quantos anos você está servindo como ogã aqui?

-"Eu nasci e cresci aqui."

-E você, para desempenhar essa função de sacrificar animais, recebeu a "mão da faca'?

-Quem nasceu e cresceu aqui em casa pode cortar qualquer coisa. -E quantos anos de santo você tem?

-Anos de santo? Muitos! Eu nasci aqui.

-Mas você teve uma cerimônia de feitúria?

-Não, não. Eles apenas lavaram minha cabeça e sabíamos mais do que todas aquelas pessoas lá fora.

-Aqui a gente não sai de iaô ou coisas assim ... eu nem quero.

Sorrio com a veemência da resposta e pergunto:

-Porque?

-"Porque eu acho que é uma palhaçada." Essa questão é bastante uma coisa daqueles adaféros e também de mulheres. É com eles que combina isso de iaô. Eu nem danço!

-Então você nunca foi raspado?

-“Eu não quero ser raspado ou algo assim." O barbeiro é o único que raspa minha cabeça.

-O senhor nunca quis? Nem quando eu era jovem?

- Não. E agora que tenho 87 anos, vou querer? Deus me livre! Aqui quando estávamos crianças, as pessoas tinham medo de passar na frente do terreiro, eles passaram pela calçada aqui na frente, ali, do outro lado... -Porque?

-Com medo de Ifá. Hoje não, hoje não existe orixá nem nada mais. As pessoas fazem as coisas ligeiramente. As pessoas lavam a cabeça, fazem negócios e já colocam terreiro ali embaixo, outro ali. Agora está se tornando um escárnio.

Anteriormente apenas havia aquele terreiro aqui, outro em Campo Grande...era assim. Hoje não. Hoje há um por trás de outro e outro atrás. A mais antiga casa de Pernambuco é essa (Sarduy, 2014, p. 250).

Pai Paulo narra seu próprio processo, enfatizando que dispensa a necessidade da feitura - justificada, por sua vez, pela garantia da transmissão familiar consanguínea. Desse modo,

as antigos não costumavam fazer o santo, simplesmente lavavam contas e assim permanecem até hoje" (Araujo, 1978, p. 18). 
sua obrigação é lida como complemento ${ }^{51}$ a algo já dado e, ao menos, virtualmente garantido. Quem, afinal, colocou o axé em sua cabeça foi a sua tia consanguínea Mãezinha:

"A gente não precisava ser feito, meu pai dizia que era só um complemento e pronto, porque pra gente o axé vem pelo sangue, só tem que completar. Mas mesmo assim, para evitar do povo falar, eu quis fazer minha obrigação. Minha tia Mãezinha foi minha mãe de santo e pai de santo foi Baba Okoto, o egum da nossa adoração, o mais velho, eu botei ele de pai de santo. Foi ela que colocou o axé. Quando eu tava sentado no até e ela foi cuspir o axé. Ela disse: 'meu filho eu preciso sentar num banco porque sua cabeça é muito forte'. Foi assim que foi feito."

De todo modo, esse é um tema que produz discussões apaixonadas por parte dos praticantes, estando longe de ser consensual e constantemente produzindo reflexão entre os membros do nagô. Recentemente, pude acompanhar uma longa discussão sobre o assunto, quando parte da família Felipe da Costa estava debatendo sobre a procedência ou não de determinados elementos envoltos na iniciação da casa em contraste com outras da mesma família.

Segundo Junior Boto, lavar a cabeça no "tempo antigo" era a obrigação mais importante da vida de uma pessoa:

"Não sei, eu acho que tem de entender, antigamente não se fazia, mas agora se faz. Não tinha deka, agora tem! Não raspava, agora raspa, então tem que estar dentro da tradição. Uma pessoa não deve se valer só do nome, só do sangue. Eu sou filho de santo de meu tio, primeiramente Deus, os orixás, meus ancestrais. Então dou seguimento às coisas que ele botou, se ele colocou, alguma razão tem. O orixá aceita. Mas tem que saber separar o que está dentro da nossa tradição e o que é de outras. No tempo antigo era assim, Pai de Santo e Mãe de Santo, Pai Pequeno, Mãe Pequena e Asipa, que é o axogum hoje em dia, Ogan era quem tocava e Iaba quem cuida do santo. Hoje em dia o povo quer inventar, mas no nagô é assim. Não tem ogan, saída de ogan. $O$ santo no nagô pode demorar muito tempo para baixar em alguém, eu mesmo saí acordado, mas Pai Paulo dizia que Xangô ía me pegar logo. Orixalá é mais difícil, ele demora a chegar. Não vê com fulano? Ele saiu de Ogan na casa dele, quando veio aqui, Oxum pegou ele, mas eu sabia que ele era de Orixalá, por isso quando fui lavar a cabeça dele, queriam que eu cantasse

\footnotetext{
${ }^{51}$ Poderíamos traduzir a noção do nagô de complemento como um suplemento.
} 
para Oxum, ele não rodava com Oxum, mas eu sabia que era Orixalá, se fosse cantar primeiro para Oxum ela tomava conta e ele na verdade é filho de Orixalá. Eu cantei tanto para Orixalá, no final ele veio, eu já sabia. Quem começou no nagô com saída de Ogan, de Ekede, foi o Sítio, mas no nagô não tem isso. Tem uma prima nossa que saiu de Ekede, Oxum de Fulano que deu o nome. Um dia ela estava na casa de Pai Guara, fez dobalé pro santo, quando Oxum Ijagura abraçou ela, ela rodou, o santo veio. Por isso que a gente dáo axé de fala, porque o dia que o santo chegar na pessoa, ele vai dizer o nome dele, [dizer] quem ele é e [vai] cantar a toada. No nagô não tem ogan nem ekede, ogan é quem toca o ilu, não tem isso de cargo..."

Um dos pontos a se destacar nessa fala de Junior é a diferença no nagô em relação a outras nações do candomblé, sobre a função de ogans e ekedes. De acordo com os praticantes do nagô, qualquer pessoa pode entrar em transe ao longo de sua vida. Nesse sentido, não há uma distinção entre pessoas que recebem o santo e pessoas que não os recebem. Ogans são termos utilizados em referencia a práticas específicas realizadas por homens, como tocar os ilus, ou limpar os bichos. Até recentemente, não se caracterizavam, por não "receberem santos", como em outras nações do candomblé. Do mesmo modo ocorre com as mulheres, toda mulher que cuida de um orixá manifestado é chamada de Yaba, o termo ekede é de uso recente, e ainda não totalmente estabelecido como um cargo ritual associado a mulheres que não caem em transe. Contudo, dada a troca constante de fundamentos religiosos entre nações onde existem esses cargos, a noção de que ogans e ekedes são pessoas que não caem em transe começa a ser mais comum nas definições de muitos membros das casas nagô no Recife ${ }^{52}$. Esse é um tema recorrente de muita discussão e especulações por parte das pessoas.

Dito de outro modo, o que emerge dessas elaborações é o aspecto de a iniciação não ser entendida como o ponto de partida para as participações rituais. Muitas vezes, essas a precedem. A iniciação é entendida como um "complemento" ou uma "confirmação" de uma série de disposições místicas e existenciais que seriam próprias de cada pessoa. Isso aponta, ao menos para o nagô, que a iniciação não é determinante no engajamento das pessoas com o culto, mas uma consequência possível de sua relação anterior. É preciso notar ainda que esse complemento não se localiza apenas no nível pessoal, mas as próprias técnicas envoltas nos rituais de chamada feitoria ou iniciação seriam pensadas como complementares ao universo em questão.

\footnotetext{
${ }^{52}$ Sobre isso, conferir a dissertação de Pedro Henrique de Oliveira Germano Lima, (2016), "Constituição da pessoa ogã no Xangô/Candomblé do Recife (O modelo nagô do Ilê Obá Aganjú Okoloyá)".
} 
Segundo relatam algumas pessoas, "a saída de iyawo", no nagô, começou com José Romão, em meados da década 50 do século passado, quando ele assumiu como pai de santo algumas das principais casas de santo da cidade. A antropóloga Aida Ester Sarduy recolheu um fragmento no antigo caderno de fundamentos de Mãe Das Dores, com uma descrição da iyalorixá que parece confirmar essa versão: "Eu, Maria Das Dores da Silva, lavei a volta no dia 9 de São João de 1932, sentei meu superior no dia 27 de julho de 1933, saí de iaô no dia 3 de janeiro de 1936" (Sarduy, 2014, p. 345).

Ao menos duas casas muito famosas e de mães de santo que eram da nação xambá, passaram para o nagô pelas mãos de José Romão após a morte do principal pai de santo da xambá, o senhor Arthur Rosendo. Esse fato trouxe para o nagô algumas cantigas que foram incorporadas ao repertório dos orixás e à saída de iyawo. Outro acréscimo, este um pouco mais recente, foi a raspagem completa dos cabelos da iyawo, uso de ikodidé $e^{53}$ e pinturas na saída dos iyawos - algumas dessas inovações vieram pelas mãos de Pai Paulo.

Sobre os acréscimos, um filho de santo me confidenciou que nada disso foi trazido ao nagô. De seu ponto de vista, essas coisas já existiam na África, mas haviam se perdido no tempo, e agora estão voltando. Pai Paulo, ao falar sobre as cantigas que introduziu no nagô, argumentou de maneira parecida:

"O povo pensa que eu inventei essas cantigas, porque ninguém cantava aqui antes, mas que nada, eu não sou compositor [risos]. Muitas cantigas se perderam, houve uma repressão muito forte na época do meu avô, então meu tio e meu pai não pegaram todas as toadas, muita coisa se perdeu, por isso eu fui atrás, recuperei as toadas de Iroko, por exemplo, as de Olofin Oduduwa. O que eu fiz foi pegar as toadas de King ${ }^{54}$ e colocar no jeito que meu pai cantava. King é muito desentoado, mas fez uma pesquisa séria, ele foi a fundo atrás dos africanos e escreveu belas cantigas, mas não sabe cantar, eu fui lendo e daí já fui colocando no jeito de pai [dizendo a Cicinho], hoje já tem gente colocando elas até no celular [risos]. “

De todo modo, o interior do complexo de iniciação nagô pode conter inúmeras possibilidades de efetivação, da qual a iniciação com saída de iyawo é só uma, dentre várias. A questão aqui é mais do que validar ou não a raspagem como único modo de iniciar alguém. Não obstante, desde que se tenha seguido por uma determinada sequência ritual, ela deve ser pensada

\footnotetext{
${ }^{53}$ Pena vermelha extraída da cauda de um papagaio.

${ }^{54}$ Refere-se às cantigas descritas por Sikiru Salami (1992), "Cânticos dos orixás na África"..
} 
em termos sucessivos em sua natureza sequencial. Isso significa que ao se trilhar o caminho de determinados eventos, é necessário manter-se atento ao cumprimento de cada etapa que ele enseja ${ }^{55}$. Retorno à etnografia da iniciação.

Encontro Junior Boto retirando alguns maços de folhas de um embrulho de jornal, compradas, na véspera, no mercado de São José, no centro do Recife. Algumas variedades não foram encontradas ou estavam secas demais na loja, e Bino me pede que as busque no Sítio.

Retorno com algumas folhas que são abundantes no terreno do Sítio, tais como relógio, abre-caminho e desata-nó. Junior já organizou as folhas em conjuntos, maços de cada uma dispostos em duas fileiras. No centro do barracão, Pai Paulo colocou uma grande bacia de alumínio. Do lado, uma vasilha com mel. Mãe Lu e Bárbara sentam-se em cadeiras em torno da bacia. Pai Paulo coloca a banquinho próximo às duas.

Ele pega agora uma quartinha com água, enche a boca e assopra sobre as folhas no chão e sobre a bacia. Diz que essa água é o orvalho do céu. As pessoas respondem: Ewe o! Faz o mesmo com pimenta da costa. Mastiga um pouco e cospe na vasilha e um pouco nas folhas no chão. Agora, faz um ato comum das invocações dos santos e do ori: toca com a mão direita os caules das plantas sobre o chão e com a mão aberta bate no topo da mão esquerda fechada. Repete a fórmula ritual usada nesse momento.

Bino lhe entrega o prato com os búzios, ele o coloca no chão, pega os oito búzios e esfrega as conchas com as mãos enquanto faz uma longa invocação aos orixás antes de jogálos: Obijoko! Mãe Lu diz que é preciso ter paciência, Pai Paulo joga novamente: Edimeji! Diz sorrindo.

Pai Paulo agora repete uma invocação a Ossaiyn e alterna os nomes dos antigos eguns da casa com saudações aos orixás da filha de santo. Após essa sequência de invocação, pega um maço de folhas corona, molha a base no mel e toca a cabeça da filha de santo. Mãe Lu segura na ponta e ele corta com uma faca. A base é posta no chão e o restante é jogado na bacia. Fazem isso com todas as folhas. Dois destaques têm de ser feitos em relação ao conjunto de folhas utilizadas nos amassis, aquelas que os praticantes do nagô consideram imprescindíveis nas iniciações e, ao mesmo tempo, que diferenciaram o nagô em relação às demais nações do candomblé. A primeira delas é a folha de Iroko, imponente árvore que ficava aos fundos do sítio de Pai Adão, tendo sido plantada pela fundadora do Sítio, Tia Inês Ifatinuke. E a segunda,

\footnotetext{
${ }^{55}$ No nagô as obrigações de iniciações são pensadas em duas etapas, a entrada de quarto e a saída, na primeira ocorre após o obori, quando é ofertado um animal de quatro patas para Exu, Ogum, o orixá da pessoa e o da casa. Na segunda, esses animais são oferecidos para as mesas divindades, acrescidas de um animal de quatro patas para cada orixá da pessoa e animais de pena para todos os santos do peji, nesses casos diz-se que a pessoa cobriu o peji.
} 
a folha tida como mais importante do amassi, o euriossayin, folha por excelência do orixá Ossaiyn, que governa todas as folhas e matas de acordo com membros do terreiro. Tal qual o orixá, as mulheres devem evitar o manuseio dessa planta. Sobre isso, Bino diz: "eu não sei explicar o porquê, mas é só uma mulher tocar nessa folha que a folha murcha”. Outro dado importante é que, para muitos, essa planta, ao ser invocada e ter seu canto entoado, permite ao orixá se manifestar em uma pessoa.

Bino e Paulinho se aproximam da bacia e, ao terminarem essa etapa, começam a "machucar" as folhas. A filha de santo é de Xangô e eles brincam que Xangô está dando uma "peia" $" 56$ neles com a urtiga que eles estão macerando. Todo esse ritual é cantado.

Após terminarem de macerar as folhas, Paulinho despeja cerca de dois baldes de água no interior da bacia. Pai Paulo despeja os pós de axé e alguns grãos, como feijões e milhos, e por fim uma generosa porção de iyerossum ${ }^{57}$. Bino tempera o banho com dendê, mel e cachaça. Assim o amassi fica pronto.

Pai Paulo então coloca o banco de madeira em outra posição, de costas para o peji. A filha de santo ajoelha-se em frente à bacia. Bino traz uma pequena gamela de madeira e uma pedra escura, um colar de contas marrom e branco e um verde e vermelho, um azul e outro branco. São os orixás da filha de santo.

Mãe Lu levanta-se de sua cadeira, gentilmente induz a filha de santo a abaixar a cabeça e coloca suas mãos na borda da bacia. Com uma caneca Pai Paulo começa a lavar sua cabeça: “deixe seu pensamento em Deus, Ifá e nos orixás", diz ele. A filha de santo inclina-se sobre a bacia e Pai Paulo esfrega gentilmente sua cabeça com o amassi. Mãe Lu repete o gesto esfregando, além da cabeça, suas costas e braços, contando para tanto com a ajuda de Bárbara. Pai Paulo segura o fio de contas e faz uma rodilha; com a outra mão, pega a pedra e pressiona bem no centro do crânio da filha de santo. Ele inicia uma longa série de toadas a Xangô. Junior Boto e seu filho começam a tocar os ilus e Paulinho aumenta o tom de voz do coro, acompanhado por Mãe Lu e Bárbara. Não há sinal de transe. Pai Paulo joga os búzios - nessa obrigação ele usa o jogo com dezesseis búzios. Caiu o odu obixé, um odu de confirmação; ele joga novamente e sai ogunda e depois um odu de Xangô, nova confirmação. Pai Paulo diz que Ogum e Xangô estão brigando pela cabeça dela. "Ela é de Xangô, mas Ogum está falando muito, está querendo passar à frente, Oxum é quem está segurando os dois..."

\footnotetext{
56 Surra.

${ }^{57}$ YÈROSÙN - é um pó amarelo decorrente da ação de cupins da arvore ÌRÒSÙN- Eucleptes Franciscana F.
} 
Nesse momento, apenas as pessoas que moram na casa estão presentes, à exceção da mãe carnal da filha de santo. Em contraste com a noite anterior do obori, não mais do que dez pessoas participam da obrigação. Pai Paulo pede para que Bino traga a tesoura e navalha que estão no quarto de santo. Ele diz para os presentes que perguntou se era para ser completo e o jogo deu afirmativo. Ele sorri para a filha de santo. Mãe Lu conduz a filha de santo para o peji. Uma pequena área no topo do crânio é aberta com a tesoura, Pai Paulo faz ali as primeiras curas (pequenos cortes rituais), depois marca os odus da filha de santo acima dos seios, primeiro lado direito e depois esquerdo. Bino completa nos braços. Mãe Lu passa os axés nesses lugares. Depois são feitos os cortes nos braços pelos padrinhos e madrinhas, cada qual em locais específicos do corpo.

Como vimos, um dos pontos centrais dos rituais de iniciação é a transferência de axé do pai e da mãe de santo para seus filhos. E não somente do pai e mãe de santo, pois padrinhos e madrinhas atuam complementando o trabalho deles em relação aos filhos e, em tese, devem ser igualmente reconhecidos e reverenciados. Esses diversos atos rituais evidenciam um complexo movimento de composição de forças que participam, vinculam e articulam pessoas, orixás e ancestrais.

O axé é algo que tem de ser transmitido a partir da manipulação correta de alguns elementos específicos. Pode ser veiculado a partir de determinadas substâncias, tendo o sangue e a saliva um papel central. A noção de axé recebeu um destacado tratamento etnográfico ao longo de inúmeros trabalhos sobre o candomblé. Não pretendo revisitar esse debate, mas trazer algumas considerações sobre seu estatuto no nagô do Recife. Como se sabe, o termo axé possui um caráter referencial múltiplo que se modifica e transforma a depender sobre o que ele atua enquanto substância e o contexto dessa ação. Marcio Goldman (2005) aponta para o caráter eminentemente relacional desse universo. Assumindo essa perspectiva, podemos então pensar no axé enquanto participação, como categoria de ação, dada a afirmação de que tudo está relacionado antes de ser. Nesse sentido, há coisas que podem ter axé, outras que não o têm, e aquelas que precisam estar corretamente relacionadas para que funcionem (Santos, 2002; Verger, 1992, Carvalho, 1984; Segato, 1984; Silva, 1995; Goldman, 2005 Opipari, 2009, Halloy, 2005; Barbosa, 2014).

\section{AsSEntar UM SANTo}


Bino termina de montar o assentamento do Xangô da filha de santo. Será o único orixá a ser assentado, os outros comerão nos assentamentos da casa e em seus fios de conta. Paulinho traz, então, dois pintos para Exu. Uma fila se forma, homens primeiro e mulheres no final. Paulinho passa a ave no contorno do corpo da filha de santo, que vai girando em seu próprio eixo. O movimento é repetido em todos os presentes, começando por Pai Paulo e terminando em Mãe Lu. Antes, a mãe de santo convida a mãe da filha de santo para se limpar e recomenda que ela dê uma volta a mais durante o procedimento: "pense em seu outro filho, para limpar ele também". Paulinho passa a ave sobre seu próprio corpo e com um movimento de varrer o chão, caminha sentido ao portão.

Após cortar o frango de Exu, Paulinho traz o carneiro de Xangô. Mãe Lu pede que a filha de santo se ajoelhe e pressione sua testa contra a testa do animal. Pai Paulo diz que ela deve mentalizar tudo o que está precisando para sua vida melhorar, e diz: "Orixá bomi xe bomi, Olorun k abio fakan, Xangô Aira Ibonam...”.

Após isso, todos os presentes repetem esse gesto e pedem coisas boas para o Xangô da filha de santo. Bino inicia o corte. Pai Paulo aumenta o tom das invocações e Mãe Lu e todos os presentes respondem a sequência de toadas de Xangô que Pai Paulo canta. Os mesmos pontos do corpo da iyawo - cabeça, costas, peito, braços e pé - foram marcados pela mãe de santo e a madrinha com o sangue do carneiro. Os ilus são tocados e o ambiente se torna mais festivo, todos batem palmas e cantam a plenos pulmões. Mãe Lu cobre com penas esses locais e amarra um pano branco na cabeça da iyawo. Junior Boto coloca a mão na testa, um tremor percorre seu corpo, ele balança a cabeça, pisa em falso, uma vez, outra vez, dá um grito. Xangô chegou.

A emoção da cena é contagiante, as pessoas cantam mais alto e batem palmas efusivamente. Pai Paulo inicia uma longa invocação enquanto Bino segue agora como solista das toadas para Xangô. O Xangô de Junior Boto levanta a filha de santo pelos braços após essa lhe bater cabeça, fazendo um sinal para que ela o acompanhe na dança. Ela faz os movimentos mais contidos, ainda desajeitados. Xangô dança com vigor, aponta para ela e abraça seu próprio peito, diz que ela é filha dele. Todos batem palmas. Pai Paulo faz um sinal para que Bino pare de cantar.

$\mathrm{Na}$ outra ponta, um filho de santo que estava ajudando a cozinhar os axés do "pinto de Exu" solta um grito. Ogum chegou também. As barras de sua calça branca são dobradas até a altura do joelho. Com um pulo ele bate com a cabeça nos pés de Pai Paulo, que o abraça. De joelhos, segue em direção a Mãe Lu, que também o abraça. Pai Paulo canta duas a três cantigas 
para Ogum e logo o manda embora. A obrigação segue com duas galinhas para Oxum e duas para Iemanjá. Fim da primeira parte.

Pai Paulo joga com oito búzios em um prato branco. "Edi meji”: "tudo aceito". Vira-se para a filha de santo e diz que ela é de Xangô, tem Ogum também, e que Ogum falou muito durante toda a obrigação: "é preciso ter cuidado com acidentes". O momento seguinte é de preparação do Iyanlé.

Terminada a obrigação, os santos ficarão arriados no peji para que possam comer e trabalhar para a filha de santo. Após esses três dias, os santos serão limpos e o ebó despachado. Um carneiro foi abatido, o Xangô da filha de santo comeu um galo e um gbegiri e, no sétimo dia, a obrigação foi considerada encerrada. Nesse período, a filha de santo ficou dormindo no salão, no local onde foi feito o obori. A madrinha dormiu com ela todos os dias. Ainda de madrugada ela era acordada e deveria tomar banho com o amassi de sua obrigação. $\mathrm{O}$ acesso ao terreiro teve sua dinâmica alterada. Toda vez que um cliente ou pessoa externa entrava no terreiro, a filha de santo se recolhia ao quarto da mãe de santo até a pessoa ir embora. Mãe Lu diz que era bom ficar no peji, mas que por conta do espaço cada vez mais limitado e pelo calor, a iyawo dormia no salão.

Depois de despachar o ebó, a iyawo dormiu no chão da sala por mais alguns dias e, no final de duas semanas, retornou para sua casa. Cumpriu, ainda, o resguardo por mais alguns dias.

Quando se trata de uma "iniciação completa", espera-se que, após a festa de saída do santo e a saída do ebó da última obrigação do quarto, a iyawo assista ao menos a uma missa. No terreiro em questão, as igrejas preferenciais são a de Santo Antônio, no bairro do Arruda, e a do Carmo, na cidade do Recife. A ida à igreja se dá acompanhada pela mãe de santo ou pelo padrinho e madrinha. O destaque dessas igrejas se justifica por terem sido palco de batizados, casamentos e missas de sétimo dia da maioria dos familiares consanguíneos do núcleo familiar com o qual convivi em meu campo.

Outra etapa a ser cumprida em uma "iniciação completa" é a visita a outros terreiros ligados ao seu. A iyawo deverá render homenagens, primeiro, aos santos no peji e, depois, ao pai ou mãe de santo que residem na casa visitada. A iyawo faz o dobale ${ }^{58}$ aos pés da mãe de santo e de outros membros mais antigos da casa que por ventura estejam presentes. Após esse pedido de benção, a mãe de santo pergunta como foi a obrigação, qual o santo, e pode dar algum conselho para a iyawo.

\footnotetext{
${ }^{58}$ Saudação ritual realizada pelo noviço.
} 


\section{SAÍDA DE IYAWO}

A saída de Iyawo consiste na principal festa ligada ao ciclo iniciático de alguém. As pessoas se preparam com muita antecedência, ao longo de muitos anos, para custear esse momento. Mãe Lu afirma que é como uma festa de casamento ou batizado, que fica para a vida toda. Contudo, alerta: "Meu pai dizia que a saída é como o casamento religioso, você faz para as pessoas. Para a gente, o que importa é o que acontece dentro do quarto, ali é o casamento civil, aquele que vale mesmo!”.

A analogia entre a saída de iyawo e o casamento ressoa com aquelas encontradas na literatura antropológica sobre o significado do termo ìyáwo: "esposa mais nova" em iorubá e "filha de santo" em português. Essa transformação na semântica do termo, segundo alguns estudiosos, seria alegórica de uma própria transformação do sistema de parentesco, da passagem de uma relação tida como de "aliança", do iniciado enquanto "esposa do orixá" em territórios africanos, para uma de "filiação mística", o iniciado como filho do orixá (Ribeiro, 1952; Verger, 1992; Binon Cossard, 1981; Lima, 1977; Wafer, 1991; Sogbossi, 2004; Silva, 2020).

Esse termo, contudo, é utilizado apenas para as pessoas que entram em transe, o que levou a todo um debate sobre o estatuto do gênero associado à prática da possessão. Jim Wafer (1991), por exemplo, estende a noção de noiva ou esposa do orixá que o termo iyawo enseja para pensar nos próprios relacionamentos entre os membros de um terreiro, como um "casamento simbólico" no qual todos os membros de um terreiro seriam "esposas" do pai ou mãe de santo, aos quais os primeiros seriam submissos.

Como alertei no anteriormente, há sempre um risco na comparação entre os materiais etnográficos de origem iorubana e os materiais etnográficos advindos da experiência das Américas negras, qual seja, o risco de que a comparação adquira o estatuto de explicação. Mas, nesse caso, acredito que a própria noção de "iyawo-esposa" possa ser melhor compreendida a partir da argumentação de Oyeronke Oyewumi (1997) em seu livro "The Invention of Women: Making an African Sense of Western Gender Discourses", a respeito do impacto das noções de gênero sobre a sociedade de Oyo do século XIX.

Segundo a autora, traduções dos termos obinrin (como mulher) e okùnrin (como homem) trazem sub-repticiamente a divisão ocidental baseada no gênero; uma derivação disso 
seria a extensão desse pressuposto à tradução de oko (esposo, anamale) e aya (esposa ${ }^{59}$, anafemale). Tais termos não seriam genderificados em termos de dimorfismo sexual de homens e mulheres para os iorubás, mas a partir de status e organização no interior de uma linhagem, localizada espacialmente em uma residência comum. Desse modo, tanto homens quanto mulheres de uma linhagem são ọo em relação às aya (esposas, pessoas de outras linhagens). $\mathrm{Na}$ medida em que uma nova esposa entrava na linhagem, a mais velha era $\rho k o$ da mais nova $e$ aya de seu esposo e dos membros mais antigos. Uma mãe pode chamar seu filho de "oko mi" - meu marido dentro da perspectiva da linhagem. É um princípio de senioridade da idade cronológica relativa à entrada na linhagem e não uma categoria exclusiva ao matrimônio. Essas são categorias relacionais. Se do ponto de vista da linhagem todas as mulheres estariam limitadas à categoria de aya, para além da linhagem, esse não seria o caso. Um dos exemplos que a autora utiliza para reforçar seu argumento se encontra nos devotos dos orixás, que são chamados de aya do orixá ao qual são devotados. Essa denominação implica que todos, homens e mulheres, tinham como ọọ o orixá do santuário porque eram territorialmente apartados do santuário, o qual tinha o próprio orixá como líder e ser mais senior da linhagem: "Șàngó é o oko de seus adoradores, porque ele é o dono da casa e eles são os forasteiros. É aceita terminologia para devotos e sacerdotes de òrìsàs serem chamados de iyawo (consorte)" (Oyewumi, 1997, p.116).

Não obstante, não estou afirmando, com essa breve passagem, que o princípio em relação ao termo iyawo encontrados em solo nigeriano operaria de forma idêntica em relação à família de santo no Brasil, do qual o termo iyawo emerge enquanto sinônimo de filha de santo. Em lugar disso, sugiro uma certa inadequação dessa noção com vistas apenas à sua tradução. Como informa Vagner Gonçalves da Silva (2020, no prelo), "no Brasil, entretanto, o adepto considera seu orixá como uma espécie de pai (ou mãe) espiritual, sendo-lhe estranha a ideia de tomá-lo como esposo (ou esposa)". Não pretendo me aprofundar nessa questão, mas apenas sinalizar que a noção de "aliança" ensejada pelo termo, a partir de sua tradução, não se situa no mesmo nível das discussões sobre sistemas de matrimônio encontrados na literatura

\footnotetext{
${ }^{59}$ Em outro texto, "Family bonds/Conceptual Binds: African notes on Feminist Epistemologies" (2000), a autora retoma essa discussão; cito na integra: "Em grande parte da África, 'esposa' é apenas uma palavra de seis letras. Embora não seja um termo comum em si, iyawo (como um exemplo) é essencialmente uma categoria subordinada. Consequentemente, muitas mulheres tradicionalmente não têm privilegiado isso que as identificam. (Embora com a imposição colonial da prática de mulheres casadas serem rotuladas com o nome de seus parceiros conjugais, ao estilo europeu, este valor africano está sob sério ataque). Ser esposa tende a funcionar mais como um papel, que como uma identidade profundamente sentida, geralmente implantada, estrategicamente. Em toda a África, a categoria geralmente traduzida como esposa não é o gênero específico, mas simboliza relações de subordinação entre quaisquer duas pessoas. Consequentemente, no esquema conceitual africano é difícil confundir mulher e esposa e articulá-las como uma categoria" (Oyewumi, 2000, p.3).
} 
antropológica. Trata-se de uma aliança de outra ordem, conforme ilustrado em uma passagem do trabalho de Carmen Opipari:

São frequentemente evocadas metáforas sociais para designar esta aliança
(cavaleiro/cavalo, marido/esposa, mestre/escravo); essas metáforas reenviam a
modelos sociais comuns, o que acentua o aspecto cotidiano da própria possessão. Mas
as metáforas têm seus limites. Apesar da proximidade semântica presente na tradução
do termo iorubá Iyawo (iaô)=esposa, não se pode entender esta aliança como um
casamento: aliança entre dois seres de mesma espécie. A fim de manter seu caráter
heterogêneo, sigo a terminologia proposta por Deleuze e Guattari (1980),
considerando-a sobretudo, como núpcias: aliança entre dois reinos. As núpcias, dizem
esses autores, são sempre antinatureza, são o contrário do casal como oposição
binária: marido-esposa, ou homem-mulher. Não se deve ver no "casal" adepto-santo
uma transposição mecânica dessas oposições. Isso explica as aspas (Opipari, 2010,
p.188).

Retornando ao Recife, as pessoas comparecem a "saídas de iyawo" com seus melhores trajes de santo e convites são elaborados e distribuídos com muita formalidade. Convidam-se todos os pais e mães de santo da rede de relacionamentos da casa. A casa é decorada nos mínimos detalhes. Tudo é preparado com muito esmero e cuidado. Antigamente, contratavamse fotógrafos para registrar a cerimônia, hoje as pessoas filmam e fotografam em seus próprios celulares e divulgam, quase que instantaneamente, pelas redes sociais. Participei de algumas saídas de iyawo ao longo da minha pesquisa de campo. A descrição etnográfica que se segue trata da saída de iyawo dos dois netos de Mãe Lu, ocorrida em julho de 2016. Escolhi essa, em específico, por ter sido a última "saída de iyawo" dirigida por Pai Paulo antes de seu falecimento e pela importância atribuída pelos familiares a respeito desse evento.

Pai Paulo inicia a festa contrariado. Sentado em sua cadeira em um canto próximo à porta do barracão, ao lado do peji, veste um bulbu africano nas cores verde e amarelo, as cores de Ifá. Com uma longa invocação, sinaliza que a saída começará. A festa começa com poucas pessoas, a maioria de filhos de santo da casa e parentes da família. Entre os convidados, há um frei, muito amigo da família.

Após a saudação a Exu, Mãe Lu chega ao barracão. Pai Paulo entrega o microfone para ela, que inicia uma longa fala para os poucos presentes. Entre eles, alguns parentes que moram no Sítio de Pai Adão.

"Hoje já começou com o primeiro netinho, bisneto dele. Bisneto, tataraneto a ser iniciado na idade de seis anos. Igual ele [Adão], que foi feito por Tia Inês nessa fase também. 
Então, é tão descendente quanto outro qualquer". Incisivamente ela afirma: "É descendente mesmo!". Antes de terminar a frase, fogos estouram anunciando um toque que se iniciava no Sítio: “está aí a prova!”, ela continua, “ele está comprovando”. Algumas pessoas respondem com axé. "Tanto ele [o iniciante], [quanto] eu e meus irmãos, somos todos descendentes de Felippe Sabino da Costa, popularmente conhecido como Pai Adão. Minha avó Maria da Hora, a esposa dele, somos descendentes também... de todos... não é só Sítio de Pai Adão, não... é Sítio de Malaquias também!” Nesse momento, os presentes batem palmas efusivas. Junior Boto, que estava na porta do peji com a cabeça baixa, levanta a cabeça e assente, o adja que estava até então parado é agitado vigorosamente. "Que Deus e Virgem Maria estão dando essa prova de existência! Da vivacidade da herança familiar dele que existe entre nós. Que Deus dê paz, saúde e felicidade e êxito para prestigiar nossa festa. Ogum papatorio!" "Ogun ye", respondeu a assistência.

Mãe Lu termina sua fala, abaixa e entrega o microfone a Pai Paulo, que continuou sentado em sua cadeira o tempo todo.

"Emi Baba Ifamuide”, diz Pai Paulo, ainda entre os ruídos de saudação a Ogum. "Ifa trouxe esse filho de volta para casa" foi o título que recebi em Ilê Ifé e estou disposto a competir, vamos ver, fazer o DNA para ver quem é mais neto biológico de Pai Adão! Vamos ver... Eu estou desafiando... estão falando muita besteira... então estou falando que é Paulo Braz Felippe da Costa, filho de Malaquias Felipe da Costa, neto de Adão, Adamassi, Baba Adam... Para os leigos, Pai Adão. Porque é Adamassi, tá entendendo, porque meu bisavô botou como mulçumano, porque meu avô se converteu em imalê... Odudua Iba.... Olofin Airo Tudugu. Olofin é... foi quem fundou esse grupo étnico. Esse que estamos agora adorando... aborisa. "Olofin Odudua."

Pai Paulo agora se levanta da cadeira e fala para os presentes, mas sua atenção está voltada para o interior do peji. "Qual é Oduduwa? Oduduwa, mas é Olofin Oduduwa! Olorun bomi xe bomi... Ojébii [todos respondem awo], kolofe ago, kolofe ago. Ojebii.” Pai Paulo hesita um pouco, Mãe Lu diz: “Omiseun”. “Omiseun”, diz Pai Paulo, e continua “Omiseun, olorun mi se bomi. Ogun Bii, Ojo kunrin, Obarinde, Oyin Funso. Olorun bomi xe bomi, Apaari, Jibiliró...”. De súbito, inicia um canto: “Awa de, Awa de oooooo, o xire imale”.

Os iyawos saem do quarto de cabeça baixa. Puxando a fila vem Thauany vestida com um conjunto de baiana simples, um pano de cabeça branco lhe cobre a cabeça. Um ikodidé está amarrado em um pequeno fio de palhas trançado que circunda sua cabeça. Seu corpo está coberto de pequenas pintas brancas e azuis feitas de giz; elas cobrem o rosto, braços, peitos e 
costas. Alguns riscos no formato dos cortes da nação estão nos pontos que foram marcados com cortes. Linhas brancas no rosto e peito.

Thalysson vem logo atrás de sua irmã. Ao contrário dela, vem com a cabeça totalmente raspada. Um losango branco cobre o topo do crânio. Quatro linhas seguem desse losango em direção ao corpo. Está vestindo uma calça branca, a parte superior de seu tronco despida e igualmente coberta de pintas brancas e azuis. Pai Paulo segue cantando - no toque, cabe ao pai de santo a função de iniciar os cânticos.

Mãe Lu e Junior Boto, respectivamente mãe de santo e padrinho, seguem à frente dos iyawos, dançando e os conduzindo pelo salão. A assistência agora está lotada, as pessoas se comprimem para conseguir acompanhar o pequeno cortejo. Os iyawos seguem em direção à porta e retornam em direção aos ilus. Pai Paulo faz um sinal e os ogans param de tocar.

"Iba Olokun, Iba Orunmila Baba Ifa...", Pai Paulo entoa mais um cântico, “Odudua lainxe funlaxo". Nova dança em frente aos ilus e Pai Paulo inicia uma dança sem sair do lugar. O clima do salão é leve, as pessoas sorriem, muitos celulares estão ligados registrando o momento. Sua dança se intensifica e ele faz um movimento com os ombros enquanto projeta o corpo para frente. Os ogans se empolgam e aumentam a intensidade do toque: "ire lowo ori mi o, Ilê loro irunmale, axe gbobo odudua...”. Pai Paulo inicia outro canto que provoca um efeito maior na assistência, é um cântico que ele introduziu aos rituais do nagô e foi amplamente disseminado. A assistência bate palmas e dança, o espaço por onde dançam os iyawos é cada vez mais diminuto entre anáguas engomadas, saias e turbantes.

Subitamente Pai Paulo encerra o cântico. "Olokun, Olokun Olorun bomi se bomi, Iemanjá Ogunté, Ogun ye, Ogun já... Kosi Oba Kan afi Olorun. Ninguém é maior do que Deus. Para sair tudo bem-sucedido. Desse iyawo. Iyawo juvenil”. Diz sorrindo para Mãe Lu. "Iyawo juvenil... Quem é bom já nasce feito, do berço traz saber, não é para quem quer. Procure com Deus se conformar, pois quem sabe, sabe e não convém teimar! É o sangue de Adão". Os iyawos são conduzidos ao interior do peji e o toque segue seu curso, cantando para os orixás na sequência do nagô até chegar em Iemanjá. Paulinho e Bino se revezam em cantar para os orixás.

Mãe Lu, de dentro do peji, dá um sinal para Pai Paulo. O toque para. Ele se levanta e vai até a porta do peji. Algumas filhas de santo mais graduadas se dirigem para a porta do peji. Elas estendem sobre suas cabeças uma grande toalha branca de mesa bordada. Alguns pais de santo de outras casas que estão na roda ajudam nessa tarefa.

Pai Paulo pede o microfone. "Olorun mi xe bomi. Baba Agboniregun, Ifa... Venham trazer o iyawo, que seja com sucesso! Iyemanja Ogunté, Olokun, que é o dono do mar, das 
águas, do mar de filhos... o primeiro foi Ogum que tá aqui representado. Olorun Fi Oba kan..." De súbito, inicia um novo cântico destinado à saída dos Iyawos: "Iyawo gege um bolonam", esse é o cântico mais comum desse ato, presente nos outros terreiros nagô.

Na maioria das casas nagô, essa é a única saída de iyawo. Nos últimos anos, Pai Paulo havia introduzido a primeira saída, com as iyawos pintadas, com a cabeça raspada e com a sequência dos cânticos de Oduduwa, mas isso permanece como algo exclusivo do terreiro Iemanjá Ogunté e outras poucas casas da família. Na grande maioria dos terreiros nagô, existe apenas uma saída, essa que agora será retratada.

Sob o ala branco, Mãe Lu vem à frente dançando na frente dos iyawos, e outros pais de santo ligados à família se juntam a ela. Os iyawos saem do peji. A mais velha está vestida com um conjunto de baiana branco, não está mais pintada nem traz o ikodide. Sobre a cabeça apenas um pequeno turbante branco. No pescoço, um quelê nas cores verde e vermelho, cores de Ogum, seu orixá. Um pequeno fio de contas está atravessado pelo seu tronco. O menino está com uma calça branca e camisa social da mesma cor, um pequeno gorro branco cobre sua cabeça. Eles seguem até o centro do salão. Os pais de santo agora abaixam o ala, dobram ao meio e o estendem sobre o chão, "a esteira do mundo", diz Pai Paulo. Em seguida se deitam e dão o dobalé sobre o pequeno azulejo quadrado no centro, o ojubo, centro do axé da casa. Mãe Lu segura a filha de santo pelas mãos, a menina dá as mãos ao seu irmão, eles circundam o ala. Eles agora fazem o dobalé aos pés de Mãe Lu e Pai Paulo, que estão parados em frente aos ilus.

Levantam-se e voltam a circular o lençol e, em seguida, fazem o dobalé na direção da rua. Pai Paulo fala "otum aiye". Levantam-se e fazem o mesmo movimento em direção ao peji e ao balé. "Osi Aiye". Agora estão novamente de frente para Pai Paulo. Junior Boto solicita as duas xícaras que estão em cima da tábua do jogo de búzios, retira um pires que cobre a caneca e a passa para Mãe Lu. Ela a entrega para a filha de santo e a cobre com um pano branco ${ }^{60}$. A filha de santo bebe o conteúdo da xícara. Pai Paulo pergunta:

- Eni orunko re. Qual o nome?

- Ogum Onire

\footnotetext{
${ }^{60}$ Segundo José Jorge de Carvalho, aqueles odobalés nos cantos são geralmente chamados "o juramento da iyawo": "ela estava publicamente prometendo lealdade aquela casa-templo, onde seu santo foi saudado e seu status como membro do culto plenamente iniciado foi reconhecido por todos. Finalmente, fez um último odobalé aos ilus, os tambores que a partir daquele momento iriam chamar sua Iemanjá para vir e possuí-la, todas as vezes que ela comparecesse a um toque" (Carvalho,1984, p. 326).
} 
A plateia aplaude. Pai Paulo torna a perguntar:

- Eni orin re. Qual a cantiga?

A menina canta com a voz baixa, um pouco retraída diante da atenção de toda assistência e de sua família. Pai Paulo canta em voz alta, os ilus acompanham. O pai de santo ergue sua mão. Os ilus param. Junior Boto entrega a outra xícara para a mãe de santo, que a entrega para o menino, cobrindo sua cabeça com um pano. Ele bebe o conteúdo e Pai Paulo lhe pergunta:

- Kini orunko re. Qual é o seu nome?

- Xango ibonan.

-Kini orin re?

- Xangô

Os presentes aplaudem com entusiasmo. Junior Boto e outros primos começam a chorar. Nesse momento, Mãe Lu é tomada por Iemanjá. Seus braços vão para o dorso, sua cabeça tomba para trás. Bárbara apoia a cabeça de sua mãe no ombro enquanto tenta tirar seus óculos. Iemanjá levanta a ponta da primeira anágua da saia de Mãe Lu.

Pai Paulo levanta os iyawos. O pano é recolhido. Ele retoma a cantiga de Ogum que a filha de santo cantou. Os ilus retomam o toque e os principais envolvidos na cena se voltam para eles, dançando para o orixá da menina. Um filho de santo vira em Ogum. Alguém vai ao seu encontro, dobra a barra de sua calça e o orixá dança ao lado da filha de santo. Iemanjá está um pouco atrás dançando com eles. O menino não solta da mão de sua irmã mais velha. Ele agora dança também.

O Ogum do filho de santo faz o dobalé aos pés de Pai Paulo e repete o movimento com Junior Boto, seu pai de santo. À medida que eram entoados os cantos, mais três Oguns tomaram seus filhos de santo e todos dançaram com a filha de santo. Dançam até que Pai Paulo encerra a sequência de cantos de Ogum e eles são recolhidos ao peji.

Pai Paulo invoca Xangô. Os filhos de santo fazem dobalé para Iemanjá, que os abraça e fala alguma coisa. A atenção agora está voltada para o menino. Ele timidamente canta e dança para Iemanjá. Sua postura é diferente do cotidiano no terreiro, onde é uma criança ativa e arteira. Em sua saída, ele está retraído, acompanhando a irmã e a avó o tempo todo. Junior Boto recebe Xangô, o toque atinge mais um clímax. Xangô abraça o menino, os filhos e filhas de santo de Junior vêm fazer dobalé aos seus pés e lhe pedir a benção. Após a sequência de Xangô, o orixá e os iyawos são recolhidos ao peji. De lá eles só retornarão ao salão após o final do toque. 
Como procurei descrever, o principal momento de uma saída de iyawo é quando o orixá anuncia seu nome e sua toada. Esse nome será entendido como o nome do santo e simultaneamente o nome de santo de seu filho ou filha.

Por exemplo, a partir de sua relação com Ifá, Pai Paulo foi nomeado como Ifátoogun (Ifá foi meu remédio); já seu avô Adão recebeu diversos nomes ao longo de sua vida, o mais importante sendo Opewatanan. Pai Paulo sempre me contava que seu avô Adão possuía uma capacidade extraordinária de promover curas por meio do uso da água e, não por acaso, sua dijina (nome de santo) era “Omitoogun” (a água é meu remédio), porque frequentemente curava doenças graves usando apenas água.

Quando uma pessoa sai de iyawo, mas não recebe seu santo ainda, é dado o axé de fala do mesmo modo. De acordo com Bino, isso se deve ao fato de que aquele orixá ainda não se manifestou, mas pode vir a se manifestar em algum momento da vida, e, quando isso acontecer, ele poderá então falar. Nesses casos, o nome do santo será recebido por intermédio de sonhos, por outros santos que se manifestem e avisem qual o nome do santo daquela pessoa ou por intuição do pai ou mãe de santo. Todas essas opções têm de ser confirmadas pelo jogo de búzios.

Há casos, contudo, que o nome é dado por algum ascendente, quando, por exemplo, o santo é de herança e já se conhece seu nome. Paulinho, por exemplo, é filho de Oguian com Oxum, mas sua dijina é Oxum Bibé e foi dado por sua avó Leônidas quando esta ainda era viva. Junior Boto diz que seu tio Paulo tentou argumentar que ele era filho de Orixala, mas não houve modo de contrariar a antiga mãe de santo, ainda mais quando o jogo confirmou. Anos depois, após a morte de sua avó, ele herdou o assentamento de sua Oxum. Bárbara, sua prima, que também é filha de Oguian, mas com Oya, tem o nome de santo de Oya Bebi.

Mãe Lu conta que sua dijina Omitogun é a mesma de seu avô Adão, como vimos logo acima. Ela diz que possui os mesmos santos de seu avô, que isso confirma a relação que ela tem com ele, tanto enquanto neta, quanto como filha de Iemanjá: "Isso já vem pelo sangue, pelas nossas descendências".

Os nomes, como disse Bastide (1973) em "Le principe d'individuation (contribution à une philosophie africaine)", relacionam-se (e são um modo de relação) de maneira específica dentro desse universo conceitual:

Os nomes não criam, assim, a personalidade, eles são somente marcas que os identificam a uma classe e, se eles são múltiplos, é que reentramos em toda uma série de classes diferentes. Dessa forma, depreende-se, ao lado de uma lógica de relação, uma lógica da atribuição, quando se passa da noção de pessoa àquela de individualidade singularizada. Nos dois casos dados, e é aquele que faz com que as soluções sejam análogas, não temos unidades senão que estruturais; mas para aquilo que é da pessoa, trata-se de uma estrutura de relações entre princípios vitais exteriores 
e interiores e, quanto às suas vidas internamente, de suas relações dialéticas (Bastide, 1973, p. 43).

No entanto, considero que, mais do que classes, os nomes indicam um potencial e instanciações de relações. A ideia é tomar a confirmação, à qual Mãe Lu se refere, como um modo de relação e não uma "significação" posterior; trata-se não de descobrir equivalências, mas de relacioná-las a partir da extensão de suas analogias.

\section{CONSIDERAÇÕES PARCIAIS}

Como procurei demonstrar neste capítulo, a iniciação é um longo processo que pode englobar sucessivas e progressivas cerimônias ou constituir-se em um único ato, "lavar a cabeça", que garantirá o vínculo daquela pessoa com seu orixá e com seus iniciadores. Essa progressividade não seria exclusiva do ponto de vista da pessoa que se inicia, podendo ser pensada em relação ao próprio conjunto de técnicas rituais envolvido nesse processo. Ao longo dos anos, os praticantes do nagô têm experimentado e adotado um conjunto de procedimentos emprestados de outras nações e casas. Mas essa experimentação é mediada pela anuência das divindades, pela confirmação do jogo de búzios e principalmente transmitida por meio dos vínculos de parentesco que permitem o acesso ao conhecimento de tais práticas e sua possibilidade de efetivação. Se pensarmos na iniciação como uma composição, os próprios rituais também devem ser entendidos como detentores dessa força e o ato de compor não seria apenas um modo de manejo com tal força, mas um impulso para esta.

Um dos principais vetores dessa força seria o sangue, ou melhor, a linha de força que conecta uma pessoa aos seus ascendentes consanguíneos e rituais. Na iniciação, uma nova composição nessas linhas é criada, dado que a iniciação incide na interdição da feitura de uma pessoa pelos seus ascendentes consanguíneos diretos. Mas essa diferença não é uma questão de sistemas que reproduziriam formas de organização social ou de transmissão de direitos e saberes. Trata-se de regimes de força e não de formas, a distinção entre sangue e santo é produzida pelo ritual.

Nas seções anteriores deste capítulo, foi evidenciado o modo relacional por meio do qual os termos de parentesco surgem no interior do candomblé nagô. Como disse mãe Lu, "só se é pai ou mãe de santo quando se tem um filho de santo". Essa elaboração não pode ser 
percebida de modo tautológico em relação a significações desses termos à luz das nossas concepções de consanguinidade. O que o sistema denota é o encadeamento dessas relações a partir de uma composição. Vários estudiosos das religiões de matriz africana reconhecem a relação mãe ou pai de santo e filhos de santo como centrais na constituição das famílias de santos, nas casas de candomblé. Como se sabe, os termos de parentesco, em geral, designam muito mais do que apenas nomes, eles expressam relações necessárias entre duas entidades: uma mãe é sempre uma mãe para alguém.. No caso do candomblé, esses termos vêm acompanhados ainda de termos em outros idiomas que não o português. No caso do nagô, é conhecido, mas não usual, o uso dos termos baba ou iya (pai e mãe) em iorubá, como uma contração da palavra Babalòrị̀à ou İyálòrị̀à.

Do ponto de vista do candomblé, podemos considerar como termos mais elementares das relações entre uma família de santo: pai e mãe, filho e filha. Usa-se também os termos irmãos e irmãs, tios e tias, avôs e avós, que, embora relevantes, não são da mesma importância dos primeiros, aparecendo mais como termos referenciais. Como apontou Halloy (2005, p.32), a "família de santo delimita um campo de relações preferenciais expresso no vocabulário da consanguinidade". Esta distinção surge e torna-se evidente em relação ao processo de iniciação. A ideia é que a formulação dessas pessoas tende a considerar a diferenciação em relação à igualdade dos referentes à sua função (pais, mãe e filhos) entre si de acordo com a perspectiva de consanguinidade mais abrangente. Por comodidade, utilizei até aqui os termos santo e sangue como se fossem, no interior da família de santo, equivalentes. Essa aproximação não é de toda excessiva, pois também é utilizada pelos meus anfitriões. Contudo, foi preciso descrever suas diferenças e principalmente as conexões que estes termos produzem.

O ritual, tal como a iniciação, é uma mediação em certo contexto a fim de produzir uma nova composição de uma pessoa e de uma família dentro de um regime de encadeamento de linhas de força que compõem uma casa de santo. Essas linhas, de sangue e de santo, diferenciadas pelo ritual, tendem a se fundir novamente quando colocadas pelo prisma daquilo que uma pessoa herda de seus ascendentes do ponto de vista de suas "heranças espirituais", tema dos próximos capítulos.

Os praticantes do nagô frequentemente vinculavam essas duas cadeias de relação, entre o santo e o sangue, na composição de suas famílias dentro das casas de santo. Nesse sentido, a distinção entre uma noção de família ou núcleo familiar latu senso e a família de santo como uma forma de organização derivada dessa primeira não traduz corretamente essas relações. A família de santo não visa à substituição do núcleo familiar consanguíneo. É possível afirmar, 
ao menos para os casos do candomblé do Recife, que as famílias de santo são indissociáveis das famílias consanguíneas; essas não se configuram como duas formas de organização ou como domínios ou entidades distintas, porque não há, na perspectiva dos praticantes do candomblé, uma distinção de tal ordem. E aqui reside uma das hipóteses que norteiam essa tese, a de que, da perspectiva dos praticantes do nagô, é possível afirmar que o "sangue" surge enquanto termo marcado a partir das relações de santo.

Variações dessa situação podem ser encontradas em outros lugares. Se retomarmos o estudo clássico de Vivaldo da Costa Lima, encontraremos uma variável dessa situação, com outra configuração, nos candomblés da Bahia. Segundo Lima (1977, p. 44), "a linhagem familiar" e a "linhagem do santo" podiam ser integradas, ele destaca, apenas em casos relacionados às dimensões hierárquicas de um terreiro, como um exemplo sobre o qual esse fato parece incidir. Sobre esse ponto, Edgar Barbosa (2012, p.117) afirma, ao analisar os casos etnográficos dos candomblés em Pelotas, que “é bem provável que essa 'mãe-de-ventre', que era também mãe-de-santo, não pudesse iniciar ritualmente a sua própria filha, dada a interdição que impede, em algumas casas, o duplo vínculo de filiação, e que, às vezes, se estende também à relação de aliança", e continua:

\begin{abstract}
Nos dois casos, sempre se herda pelo sangue (pois o santo se faz com sangue), podendo haver, contudo, variação em termos do axé distribuído por vínculos de consanguinidade que podem incluir, em delicadas alianças rituais, os laços de filiação mítica, ou então do axé distribuído por estes últimos que não necessariamente incluem os primeiros. É significativo que os materiais de Lima chamem a atenção para a possibilidade de uma elisão da mediação ritual e da qual resulta uma conexão direta, ou indireta se for o caso de alguma herança familiar, com a filiação mítica (Barbosa, 2012, p. 114-15).
\end{abstract}

No Recife, o sangue é o principal meio por onde passam as relações de santo, e isso não se expressa apenas ao nível da organização de uma casa com proeminência dos laços consanguíneos, mas como um dado comum aos praticantes em geral, que associam seus vínculos com o santo à sua presença em seu sangue. Nesse sentido, o sangue "confirma" sua relação com o santo. Esses vínculos não são expressivos dessas linhas, mas antes, as dispõem de modo a serem passíveis de transmissão - conformando um dos sentidos, que entendo existir, do termo obrigação. Desse modo, a iniciação ritual, traduzida como uma "filiação", não apenas instaura ou confirma uma relação entre a pessoa e seu santo, mas também estende a relação entre o iniciado e seus iniciadores e seus próprios orixás. 


\section{CAPITUlO 2 - AS ObRigaÇões COM OS EGUNS}

Pai Paulo era o Alapini da família de Pai Adão. A noção de "família" aqui denota uma vasta rede de terreiros que possuem filiação com o Sítio de Pai Adão. Alapini é o alto sacerdote do culto dos eguns, os antepassados ${ }^{61}$. Em Recife, diferentemente de na Bahia, os eguns não possuem terreiros específicos e apartado dos terreiros de orixás. A diferenciação espacial é mantida, mas o distanciamento é nuançado pela antecipação dos rituais em um mesmo local. Os eguns são sempre cultuados no primeiro momento, antecipando as outras obrigações. Pai Paulo possuía grande intimidade com eles, podia passar horas falando dos antepassados e das especificidades de cada um dos eguns. Era visível sua animação quando havia uma obrigação, pois seu humor ficava melhor e ele tornava-se mais comunicativo e expansivo. Sobre o título de Alapini, me contou Pai Paulo: "Um dia eu estava numa obrigação no Pátio do Terço ${ }^{62}$ e Yaya disse 'Hey Alapini! Você parece muito com seu bisavô'. Meu tio Zé Romão ouviu aquilo e dias depois foi confirmar no jogo e viu que eu era um Alapini mesmo. Já veio das heranças espirituais de minha família".

Os ancestrais estão presentes em diversos momentos dos rituais e são extremamente importantes na composição das casas nagô, seja como destinatários de obrigações específicas ou percebidos no decorrer de rituais em meio às invocações que os convidam a participar das obrigações, ou mesmo supervisioná-las. O estilo ritual pelo qual tais obrigações são executadas são como memórias desses antigos praticantes do nagô, suas idiossincrasias.

Os eguns são os mortos ${ }^{63}$ ou, mais precisamente, as "almas dos mortos", seus “espíritos”. Essa é uma condição universal: quando uma pessoa morre se torna um egum. Mas nem todo egum é cultuado, somente aquelas pessoas que em vida cultuavam os orixás podem tornar-se um egum reverenciado. Mas isso não é tudo. Como veremos, ao lado dos eguns que foram pessoas ilustres e importantes na família de santo, os ascendentes consanguíneos de uma

\footnotetext{
${ }^{61}$ Esse título é encontrado também na Bahia, sobre isso escreveu Juana Elbein dos Santos: "Cada "terreiro" Égún tem seu Alágba, e o Alapini é o chefe supremo de toda a seita" (Santos, 1986, p.126).

62 Outro importante terreiro nagô de Pernambuco, localizado no Bairro de São José, área central da cidade, tido como o primeiro terreiro da cidade. Atualmente o terreiro está fechado, após a morte de Badia, e os assentamentos desse terreiro se encontram no terreiro de Pai Raminho de Oxóssi, em Olinda. Conferir também Brandão\&Motta (2002).

${ }^{63}$ As teses de José Jorge de Carvalho (1984) e Arnaud Halloy (2005) possuem a melhor descrição etnográfica sobre o mundo dos eguns em Recife. Sobre o contexto dos candomblés da Bahia, ver Bastide (1958); Julio Braga (1988); Elbein dos Santos (192); Flaksman (2014); Sogbossi (2004). No Rio de Janeiro: Robson Cruz (1995). No Rio Grande do Sul, ver Barbosa (2012).
} 
pessoa podem - e na visão dos candomblés do Recife, devem - igualmente ser cultuados, mas somente pelos seus descendentes consanguíneos em suas próprias obrigações.

Os eguns recebem, ainda, uma outra divisão. São diferenciados pelo sexo: eguns machos (Egun Okunrin) e fêmeas (Egun Obinrin). Há ainda outra distinção a ser considerada. Aqueles eguns que faleceram muito tempo atrás e já receberam muitas obrigações são considerados como Eguns Agbas, eguns velhos e de mais força. Os eguns novos são chamados de Aparakas, ou simplesmente eguns.

Os eguns são cultuados em um local específico, o quarto do balé ou balé. Em geral, uma pequena construção, sem janelas, localizada aos fundos dos terreiros. Esse quarto é a morada dos eguns e seu acesso é terminantemente proibido às mulheres. Dada essa restrição, é comum que esse quarto possua uma antecâmara que impossibilite um olhar desavisado quando sua porta está aberta. Nos balés menores, ao menos uma cortina ou véu cumprem esse papel; em todos os casos, quando a porta do balé está aberta as mulheres são alertadas para que permaneçam distantes.

Os rituais aos eguns dispõem de maneira mais enfática a separação ritual entre homens e mulheres no decorrer das diversas cerimônias no nagô. Mulheres e homens possuem diferentes atribuições específicas na dinâmica ritual. Nos atos rituais, "não se pode misturar" homens e mulheres. Cada momento do ritual implica em uma relação de "boa distância" entre homens e mulheres, na distribuição do trabalho ritual e dos procedimentos envolvidos em suas etapas. A própria saudação aos eguns evidencia essa separação, como registrou José Jorge de Carvalho:

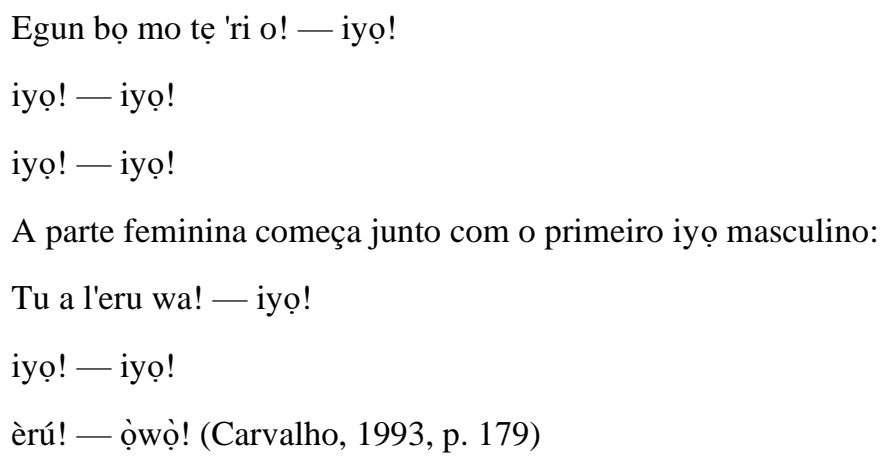

Nos dias dos rituais aos eguns, as mulheres não apenas devem evitar o espaço próximo, como também qualquer tipo de contato com as coisas do balé: comidas, bebidas, corpo dos animais oferecidos, além do contato físico com os homens que "trabalham" dentro do balé. Meus amigos do nagô afirmam que as mulheres não podem entrar em contato com os eguns 
porque "geram a vida", e os eguns são o domínio dos mortos. Eles costumam narrar casos em que antigas mães de santo, "afoitas", teriam, no final da vida, visto o interior do balé, e que por isso teriam "antecipado sua morte". Para entrar no balé, "tem de ser um homem preparado!", alertam. Tais quais as mulheres, crianças de ambos os sexos são terminantemente proibidas de acessar o balé ou mesmo se aproximar dele por essa razão. É um local de "muita força”!

Mãe Lu conta que seu pai, talvez para testá-la ou mesmo verificar sua prescrição, havia dito que, se ela desejasse, poderia tê-la "preparado" para ser uma Iyá Agan, uma mulher que pode ter um acesso mais íntimo ao universo dos eguns, o que ela prontamente rejeitou. Ela várias vezes afirmava:

"Ali é o nosso machismo. Só homem entra! Mulher só entra depois que morre.

Mas quem comanda ali é uma mulher. Oyamesan, ela quem comanda os eguns, ali dentro o reinado é dela. Os homens cuidam, mas no balé os eguns mais fortes são os da mulherada. Um egum de uma mulher é mais forte e pesado."

Essa é outra característica central ao mundo dos eguns: somente o orixá Oya é cultuado nesse espaço ${ }^{64}$. Desse modo, Oya é cultuada tanto no peji (quarto dos santos) quanto no balé. Mas isso não faz dela duas entidades distintas. Pai Paulo dizia que não existe "Oya do balé", enfatizando que "Oya é Oya", e lembrava: "Meu pai sempre dizia que se você tirasse Oya do peji e levasse pro Balé ou pegasse a Oya que está no balé e levasse pro peji, que elas trabalhariam do mesmo jeito. São o mesmo orixá”. Idelfonso acrescenta mais uma diferenciação. Segundo ele, o modo correto de saudar Oya Egun no balé é a saudação aos eguns: "Egun bo mo tẹ 'ri o!", enquanto no peji seria: "Epa Hey!”, esta última saudação não seria adequada ao saudar Oya no balé, embora muitos praticantes tenham adotado para saudar Oya no balé. Sobre isso, escreveu José Jorge de Carvalho:

Ela é o único santo que pertence ao mesmo tempo ao quarto do santo e ao quarto do egum. Os membros enfatizam que é o mesmo santo, iyansan, e não dois; sempre que ela está no quarto do santo ela recebe o nome de Oya Orisa (Oya é outro nome usado às vezes para Iyansan); e quando ela está no quarto do egum, ela é Oya Egum. Então, há um assentamento de Iyansan perto dos eguns, bem como os que estão dentro da sala do santo. Dizem que ela é extremamente poderosa, uma guerreira, vinda de um país diferente de todos os outros orixás: enquanto os outros são Nagô, um membro do culto me contou: Iyansan veio da terra de Tapa. Essa característica de ser estrangeiro parece estar presente em alguns aspectos de seu simbolismo. Dizem que ela é a rainha

\footnotetext{
${ }^{64}$ Em termos de possuir uma representação material, outro orixá a ser invocado no balé é Obaluaiye, mas há uma variação importante. Seu nome dentro do balé é Ologbojo e há apenas um cântico destinado a ele, o cântico 28 da seção dos Eguns do Livro Cânticos Sagrados do Xangô do Recife de José Jorge de Carvalho (1993, p.186), “Egúngún fẹ ba Ológbojo l'e rí un lyáyáríyá Ológbojo l'e rí un”. A prevalência nos cantos e nos atos rituais é totalmente dedicado a Oya.
} 
do carnaval; como o quarto de santo está fechado durante esses dias, e os outros santos tendem a deixar a terra, ela fica por perto, protegendo a casa contra qualquer possível invasão de maus espíritos, Esus ou eguns obscuros, que tendem a se mover livremente durante os dias de carnaval. Iyansan é unanimemente associada a Santa Bárbara e seu dia anual é 4 de dezembro (Carvalho, 1984, p. 84).

Essa observação diz respeito à capacidade desse orixá atuar entre esses dois domínios, o dos orixás e dos eguns, permanecendo a "mesma divindade". Um relato de um dos interlocutores de José Jorge de Carvalho explicita essa característica e ao mesmo tempo as diferentes interpretações em jogo nesse caso.

\begin{abstract}
/.../Segundo José, que Iansã comporta-se como um homem (oko, termo iorubá que as pessoas do xangô usam bastante), sempre que está dentro do quarto de igbale. Em suas palavras: "Iansã é considerada como um oko lá dentro, ela é tratada com a autoridade de um oko. Lá ela senta-se com os homens, autoritária; a última voz é sua, ninguém mais ousa tomar qualquer decisão". A observação de José aqui parece derivar-se principalmente da crença de que Iansã é guardiã dos eguns. Mas, como autoridade é um atributo muito masculino (como Rita Segato demonstra em sua tese), Iansã parece masculina, consequentemente, sempre que se encontra naquele contexto de poder. Pedi a Malaquias que expressasse seu ponto-de-vista sobre o assunto e ele disse que no igbale Iansã vem como uma mulher, porque ela é uma mulher. Acrescentou, contudo, que ela fala lá com uma voz diferente (provavelmente ele se refere à voz rouca dos eguns) da que tem no quarto do santo e talvez essa diferença de voz explique algumas pessoas acreditam que ela lá vem como um homem (Carvalho, 1984, p.286).
\end{abstract}

O culto a Oya na "parte dos eguns" e na "parte dos orixás", evidencia o modo pelo qual os praticantes do nagô manejam as relações em outros domínios rituais, o que permite também uma passagem a outros universos religiosos, como, por exemplo, o da Jurema. Oya é tida como a dona dos "espíritos", da "fumaça" e nesse sentido a Jurema é tida como outra possibilidade de lidar com os eguns. No jogo de búzios, a caída da configuração na qual fala Oya e os eguns é denominada "Obirossum", sobre o qual as pessoas atestam que traz um "recado da Jurema". Pai Paulo dizia que, quando essa caída saía no jogo de seu avô, ele "despachava" a pessoa para um terreiro de jurema, pois ele não trabalhava com os mestres e mestras:

"Veja, morto é morto. Um egum, um ancestral, é um morto, um mestre, um espírito de luz, é morto. Mas o jeito de trabalhar no balé é um e no lado da jurema é outro. Eu tenho por tradição familiar do lado materno muita coisa de jurema, minha avó e meu avô maternos eram grandes juremeiros, minha mãe. Eu não fui muito pelo lado da jurema por 'lavagem cerebral' do meu pai. Mas não pode misturar, jurema é uma coisa, candomblé é outra..."

Pai Paulo aludia às possíveis analogias dentro dos universos religiosos, "um morto é um morto", uma definição sobre a transformação das pessoas pelo advento da morte. É uma condição geral. Por isso, é preciso "individuá-la" a partir do território em que se desenvolve o 
ritual, pois ao entrar em relação com esses espaços rituais o espírito se transforma: se for no balé, será um egum, se for na jurema, um mestre. Ou seja, tem-se um modo de diferenciação consciente contra um fundo de possíveis similaridades que a coletividade instaura. Segundo o modelo proposto por Pai Paulo, quando uma pessoa o procurava a partir do recado do jogo de búzios, era preciso ver o que aquele "recado" específico diz para ela. Ou seja, é preciso tornar o recado particular daquele espírito - se é um egum ou um mestre -, de modo a especificá-lo para o consulente, a partir da extensão do contexto coletivo (balé ou jurema), que também é, concomitantemente, transformado (aquela situação irá compor o repertório de imagens e eventos que caracterizam aquele espaço ritual).

Voltemos à fala de Mãe Lu e a uma constatação compartilhada amplamente pelos membros do nagô em geral: os eguns das mulheres são mais fortes e mais perigosos. Uma das inúmeras obrigações de balé da qual participei foi para uma mulher que estava sendo perseguida por seus dois irmãos falecidos. A situação era tão dramática que, durante o ritual, ela foi "aproximada ${ }^{65 "}$ pelos eguns - um modo de possessão sutil, mas muito perigosa. Ela ficou sentada em um canto o tempo todo e, por vezes, vociferava alguma coisa contra os homens que conduziam a cerimônia. Nesses momentos, sua fala adquiria um ar mais grave e pesado e referia-se a si em terceira pessoa. Um dos ojés(termo que designa os homens que conduzem as cerimônias no interior do balé) mais experientes notou que se tratava do egum de seu irmão falando. Ele então interpelou a mulher e ela disse o nome dele. Instantes depois, o outro irmão anunciou sua presença. Os ojés se olharam e foi ordenado que ela tomasse mais um banho de akoko (folha principal dos eguns). Ao final da obrigação, os eguns foram, enfim, despachados, e a fisionomia da mulher se transformou. Sobre isso, um dos responsáveis pela obrigação concluiu:

\footnotetext{
"Essa obrigação foi muito pesada, eles estavam aqui o tempo todo em cima da irmã. Queriam levar ela embora de todo jeito. Eu fiquei com medo. Joguei e o egum de vô e de Pai Paulo disseram: Faça e confie! Edimeji. Eles foram embora, mas só foram porque eram eguns de homem, se fosse um egum de
}

\footnotetext{
${ }^{65}$ Os termos referentes às experiências de transe também se modificam de acordo com os territórios religiosos de onde elas se desenvolvem. Por exemplo, um orixá "pega" seu filho de santo, ou a pessoa "vira no santo", um mestre ou entidade da jurema "manifesta" ou "trabalha" no corpo de alguém, e um egum se "aproxima" ou "atua" na pessoa. Essas variações não são modos de nomear diferentes estágios ou formas de possessão, mas são relativos às modificações da própria experiência do transe.
} 
mulher, não teria jeito /nesse momento todos em nossa volta assentiram com a cabeça."

Casos como esse, evidentemente não tão dramáticos, são frequentes. Pai Paulo, por exemplo, iniciou um jovem rapaz para que ele pudesse enfim ficar livre da "influência materna". A mãe desse rapaz faleceu quando ele nasceu; segundo Pai Paulo, o menino sempre teve uma saúde frágil, até que o jogo alertou que era o egum da mulher preocupada com o filho. Nesses casos, os praticantes do nagô costumam associar essa outra característica dos eguns: a presença deles, mesmo quando bem-intencionada, pode acarretar desajustes e doenças na vida das pessoas. "Às vezes o egum acha que está fazendo o bem, mas tá ali prejudicando", comentou Pai Paulo. Junior Boto me explicou uma vez que os eguns e humanos, podem estar juntos, mas não devem se misturar, apontando para graus apropriados de relação.

Todo balé possui um egum principal masculino e um egum principal feminino. Quase sempre os fundadores da casa que já faleceram. Nesses casos, o balé é inaugurado após as suas cerimônias funerárias. Esse é o caso do Balé do Sítio de Pai Adão, onde o líder dos eguns masculinos é o egum do famoso babalorixá Pai Adão, evocado com seu nome ritual Opewatanan e o egum da fundadora da casa Tia Inês, Ifátinuke. No terreiro Ilê Iemanjá Ogunté, o balé é dedicado ao egum de Malaquias Felipe da Costa, Ojébii, e Dona Leonidas Felipe da Costa, Omiseun. Pai Paulo conta que "plantou" o balé dessa casa após o falecimento de seu pai - o modo como as pessoas se referem ao inaugurar um balé é plantar o egum -, mas o egum feminino era o de Tia Vicência, antiga mãe de santo do Sítio, filha adotiva de Tia Inês. Após a morte de sua mãe Leônidas, seu egum teria "passado à frente”, pois era mãe carnal da família, "cabaça ventre", como Pai Paulo dizia, e que por isso ela teria ganhado a primazia de liderar o balé de sua família. Contudo, o egum de Tia Vicência continua a ter grande reverência na família, pois ela era mãe de santo de Mãe Lu e foi plantada naquele balé.

Há casas que possuem como eguns principais os ascendentes consanguíneos de seu fundador. Nesse caso, o que é observado é o fato de que eles, em vida, fossem iniciados aos orixás. Como escrevi acima, toda pessoa deve render homenagens aos eguns de seus ascendentes consanguíneos falecidos, mas isso não os habilita a serem cultuados enquanto eguns de toda uma casa ou comunidade, posto somente ocupado por aqueles que eram feitos no santo. Igualmente, os eguns da família de sangue do terreiro que não possuíam vínculos diretos com o mundo dos orixás quase não são reverenciados, só o sendo em obrigações específicas de membros da família. 
Os principais eguns dos terreiros nagô são os antigos membros e fundadores das casas de candomblé. Eles são invocados e cultuados no balé de todas as casas. Os principais da família são Ato, Aro, Adifabola, Ajoile, Okotorojo, Opewatanan, Ojo Kunrin, Oje Bii, Agbabalulu, Jibilaro, Apari, Orisadare, Sango Laari, Ifabaila, Ojeladee Ifatogun. E as principais eguns da família são Majegbassan, Ifatinuke, Fatinuke, Omiseune OyinOsun. A ordem hierárquica das invocações depende da casa em que estão sendo cultuados e da pessoa que os invoca, a depender da sua proximidade genealógica ritual e consanguínea em relação a esses eguns.

Ao longo de minha pesquisa, pude participar de diversas obrigações aos eguns. Logo no início do meu campo do mestrado, em 2014, Mãe Lú telefonou para Pai Paulo avisando que eu já estava em Recife e que "iria trabalhar com ele agora". Durante essa ligação, Pai Paulo avisa a ela que antes de começar esta pesquisa eu precisaria "dar uma obrigação para Ifá e no balé" e que somente assim ele poderia "me passar as coisas". Mãe Lú então me avisou: "Paulo não pode dar nada para você do que Jorge [José Jorge de Carvalho] não tivesse ganhado de meu pai Malaquias. Quando Jorge foi fazer sua pesquisa, ele teve de dar uma obrigação para Orunmilá e outra no balé, e que, por isso, você terá de fazer o mesmo".

No meu caso, o balé foi o último espaço ritual do nagô ao qual fui convidado a participar - o que considero um gesto de extrema generosidade e confiança por parte de meus anfitriões e que muito me honra. Pai Paulo me convidou a adentrar o espaço com a condição de que eu não escrevesse nada do que eu havia visto ali. Não poderia nem ao menos comentar com qualquer pessoa o que aconteceu. Esse é um compromisso que não estabeleci apenas com meus amigos em Recife, mas também com os eguns. Essa relação com os mortos é traduzida em termos do "segredo" (awo, em iorubá). Esse segredo não implica apenas na dimensão de um conhecimento que não é acessível, mas a algo que só pode ser compartilhado entre aqueles que adentram naquele espaço, um modo de relação. Sobre isso, descreveu José Jorge de Carvalho:

Agora que o ritual para os eguns foi descrito e seus principais símbolos discutidos em algum detalhe, o leitor pode apreciar o segredo que o envolve e que é dramaticamente expresso numa estória que um membro do culto contou-me. Um homem do Sítio uma vez perguntou-me se eu sabia qual a relação que Xangô tinha com o igbale. Respondilhe que só sabia que ele nunca vai lá, porque Xangô não gosta dos mortos (essa informação é lugar-comum entre os membros do culto e Rita Segato menciona-a quando discute a personalidade de Xangô). Então aquele homem disse que iria contarme porque Xangô não entra no igbale, informação de que eu não dispunha, mas que, ele disse, era de importância fundamental para meu estudo. Contou-me o seguinte: "Xangô foi convidado por todos os ojés para ir ao igbale com eles e participar na coisa (cerimônia). Então ele viu as coisas, como tudo era, como tudo era feito, e assim por diante. Quando ele deixou o quarto ele contou a todos o que tinha visto. Os ojés viram aquilo e o expulsaram, proibiram-lhe de nunca mais entrar ou voltar lá, porque ele falara demais. Ele perdeu toda a sua hierarquia com relação ao igbale; ele não tem qualquer hierarquia na sociedade e é até mesmo proibido pronunciar seu nome dentro do quarto dos eguns". Eu então perguntei ao homem o que foi que Xangô contou do 
que vira./.../ O homem respondeu: "Ele contou às pessoas o seguinte: Todos têm a crença, certo? (De que os eguns estão lá, de que deve haver coisas dentro). Então ele contou a todos que ele não tinha visto nada, que ele não vira nenhum egum lá. Ele comportou-se como um descrente, um ofidan (aquele que não crê, expressão usada por membros do culto para descrever estranhos e mesmo pessoas de dentro que duvidam do poder dos santos). E por essa razão, ele é zero para a sociedade dos ojés: ele não vai lá e seu nome não é pronunciado lá". Esse relato, embora muito curto e simples, é extremamente vigoroso, porque lida com algo que mantém unidas as pessoas do xangô: o compartilhar de segredos e a impossibilidade de sua revelação a estranhos. Os estranhos sempre sentem que os filhos de santo conhecem muitas coisas secretas, e o domínio dos eguns é especialmente secreto. O real valor do segredo, nesse contexto, parece ser o de impedir as pessoas de formarem qualquer noção sobre aquilo que não pode ser visto, mais do que meramente impedir-lhes o acesso à observação de coisas que elas sabem existir dentro de um espaço altamente reservado (Carvalho, 1984, p.284).

Os eguns são forças poderosas com as quais as pessoas sem o devido preparo não saberiam lidar. No caso de uma pesquisa antropológica da qual resulta um escrito, parece-me que o motivo de tamanha preocupação seria o efeito da escrita sobre os eguns em mundos distintos. Mas não somente, a imanência de tal perigo reside na própria escrita, e ela também era para Pai Paulo um modo de relação, como podemos notar nos escritos de seu site sobre Ifá.

Minha relação com meus amigos e interlocutores em Recife se deu por meio dos rituais. A própria antropologia, aqui, foi pensada nos termos do ritual, no modo como essas pessoas convencionalizaram suas experiências com outros antropólogos que desenvolveram suas pesquisas. "Você só poderá fazer sua pesquisa se passar pelas obrigações que José Jorge passou", disse-me Pai Paulo. O ritual é um modo de lidar com outras forças, com a diferença; com os antropólogos, portanto, não seria diferente. Meus amigos interpelam e abordam a antropologia a partir de suas posições, mediando esses encontros em seus próprios termos.

Após essa breve síntese do universo dos eguns, apresento a organização deste capítulo. Nesta seção, retomo quatro momentos etnográficos distintos. O primeiro foi uma obrigação para os eguns e Exu prescrita pelo jogo de Ifá para uma nigeriana que pretendia assumir um cargo de "chefia feminina" política da Nigéria. Essa obrigação foi determinada pelo jogo de Pai Paulo, confirmando um jogo anterior de seu amigo nigeriano. Ela permite aceder ao universo dos eguns, os ancestrais que, como vimos, são importantes no dia a dia do terreiro e constituem em um domínio cental no cosmo nagô.

O segundo momento resulta dos desdobramentos do recado de um jogo de confirmação durante a obrigação das calungas do "Maracatu Raízes de Pai Adão". Espera-se com isso demonstrar como determinadas convencionalizações dos rituais nagô são desdobradas a outros contextos (como o carnaval), como é interpretada a não efetividade de um recado do jogo e de que forma a composição dos vereditos é atualizada nesses casos. O carnaval é tido como um 
períododos eguns e são múltiplos os modos com os quais os vivos se engajam com os ancestrais nesse período do ano. Minha intenção é descrever como os ancestrais atuam no cotidiano das pessoas no decorrer desse período.

O terceiro momento diz respeito aos ritos funerários que compõem o mundo dos eguns. Descrevo todas as etapas do complexo funerário: velório, sepultamento e axexê. É um período extremamente grave e solene, que contrasta com os rituais dos eguns realizados no cotidiano.

Por fim, na última parte deste capítulo, acompanho os desenvolvimentos após o falecimento de Pai Paulo, ressaltando sua presença ativa na vida do terreiro mesmo após a sua morte. Reencontramo-nos novamente com a centralidade do jogo de búzios, um aspecto constitutivo e valorizado da sua expertise enquanto um sacerdote, e seu posterior engajamento, agora como um ancestral, que continua a decidir e intervir na vida de seus descendentes.

\section{OBRIGAÇÕES AOS EGUNS}

São considerados como obrigações todos os rituais para as divindades ou ancestrais do universo nagô. Em geral, realizam-se no momento de iniciação de alguém no culto ou, no caso de pessoa já iniciada, devem ocorrer anualmente ou em períodos intercalados de anos. Outras obrigações são dadas pela casa ou terreiro, como as anuais em honra ao orixá patrono da casa ou aos orixás principais (que coincidem, na maioria das vezes, com o orixá do pai ou mãe de santo fundadora da casa). Há ainda pequenas obrigações chamadas de ebó, que são realizadas obedecendo ao desígnio do jogo de búzios ou Ifá. Essas são mais frequentes e menos dispendiosas, abrangendo uma gama de pessoas que não possuem vinculação direta com o terreiro. Os eguns recebem sempre as primeiras obrigações relativas ao ciclo ritual das casas e pessoas no universo nagô. Sua primazia é de tal monta que mobilizam a maior parte da intensa vida ritual dos terreiros.

As obrigações aos eguns são o primeiro engajamento ritual que uma pessoa estabelece dentro do complexo de iniciação nos candomblés nagô do Recife ${ }^{66}$. Ao se iniciar, uma pessoa deve render uma "homenagem" aos seus ancestrais e ser apresentada aos "eguns da casa" para

\footnotetext{
${ }^{66}$ Esse ponto também foi notado por Arnaud Halloy, que sobre isso escreveu: “o iniciado, a primeira obrigação de egum corresponde ao seu registro genealógico em uma (nova) linha de iniciação. A partir dessa primeira oferta feita em seu nome, é criado um vínculo com os antepassados da família a quem ele deve adorar a partir de agora. Em outras palavras, ele passa a pertencer a uma família sagrada, inscrevendo-se ritualmente na genealogia da família. Obviamente, isso diz respeito a um indivíduo fora da família biológica que seria iniciado no culto. Para um membro da família biológica, de fato, o vínculo sanguíneo precede o vínculo de iniciação e sempre será considerado mais forte. Essa inscrição genealógica destaca o caráter "coletivo" da obrigação de egum, em oposição ao caráter 'individual' da obrigação de santo" (Halloy, 2005, p. 335).
} 
que eles possam "trabalhar" por ela. Desse modo, a pessoa inclui em sua genealogia os eguns da casa e passa a considerá-los também como ancestrais seus. Arnaud Halloy escreveu sobre isso considerando a relação entre traçar sua genealogia a partir de sua iniciação e uma mudança relativa ao tipo de tratamento dado aos eguns, incorporando eles como seus:

\begin{abstract}
Gostaria agora de chamar a atenção para o tipo de relacionamento que é valorizado dentro do culto entre o iniciado e seus "(novos) ancestrais". É de fato interessante notar a esse respeito que o vocabulário que define esse novo relacionamento pode variar dependendo do contexto do enunciado e dos interlocutores presentes. De fato, durante meu primeiro trabalho de campo em 2001, bem como durante meus primeiros meses de investigação em 2002, as pessoas - e eu - se referiam a Malaquías - que é sem dúvida o ego mais invocado e mais influente do mundo, da família de santo onde eu fui iniciado - chamando-a pelo primeiro nome "Malaquías". Após minha iniciação, em janeiro de 2003, não se tratava mais de "Malaquías", mas de "seu avô" ou "nosso avô". Fui encorajado a me referir a ele como "meu avô", e não como "Malaquías", impessoal demais para o novo tipo de relacionamento estabelecido pelo ritual. Essa referência foi incentivada porque indica não apenas o efeito do registro genealógico mencionado acima, mas também uma marca de ternura, carinho que qualquer filho ou neto deve manter em relação aos pais. No entanto, eu tive que usálo sem ênfase na presença de interlocutores externos à família de santo, para que não fosse percebido como uma pretensão de minha parte subir à altura dos consanguíneos. Esses tipos de táticas sócio-discursivas são comuns na comunidade do candomblé, e seu domínio depende da manutenção do equilíbrio dos relacionamentos dentro da família (Halloy, 2005, p.334).
\end{abstract}

Não obstante, os eguns de uma família são tidos como aqueles mais próximos, em especial os ascendentes diretos, pai e mãe. São estes que "ajudam mesmo" os filhos. Um egum de uma pessoa que era iniciada é considerado como tendo mais força e poderá interceder junto aos orixás para que eles aceitem suas oferendas e pedidos.

Quando retornei a Recife, no final de 2015, para iniciar minha pesquisa de doutorado, Pai Paulo recomendou que eu, enfim, fizesse a obrigação aos eguns "que ficou faltando" na minha pesquisa de mestrado e em "agradecimento ao título conquistado". Na época, eu já contava com os recursos para tal e, portanto, concordei. Pai Paulo então decidiu que a melhor data para essa obrigação seria no sábado de carnaval de 2016. Segundo ele, essa era a melhor data porque coincidia com o dia que seu avô costumava dar comida aos eguns no Sítio. Ele me consultou se eu tinha pai ou mãe falecidos. No meu caso, somente meu pai. Então ele disse que eu deveria cultuar o meu avô paterno e não somente o egum de meu pai, e as obrigações deveriam ser em nome do meu pai com a anuência de meu avô paterno. Há mais, contudo: sou um homem branco, mas minha família por parte de pai é negra, e negros eram meu pai e meu avô. Pai Paulo dizia que eles, por serem negros, tinham mais força para interceder aos meus orixás do que a parte de minha família materna, que é branca ${ }^{67}$ Pai Paulo me disse que meu

${ }^{67}$ Desenvolvo mais sobre essa noção de "hierarquias de força” no capítulo quatro desta tese. 
avô era o gerador familiar de minha família de culto e que eu deveria sempre cultuá-lo primeiro; mas todos os "meus eguns", sejam os maternos e os paternos, deveriam ser cuidados e zelados quando eu fizesse obrigações no balé.

De todo modo, a linha de sangue e de santo produzem novas composições nessas genealogias a depender da pessoa que está realizando a obrigação e de circunstâncias sobre o ritual em si: se é um ritual para a casa de santo, para uma obrigação anual ou para um fim específico, como uma determinação do jogo de búzios. O que esses casos demonstram é que essas genealogias não são fixas e muito menos dadas a priori, mas sim contextuais e moventes.

As obrigações aos eguns e aos orixás costumam ser divididas em momentos distintos, que se intercalam. Em geral, começam por uma série de saudações em iorubá - as invocações -, seguidas da apresentação das comidas e animais, o corte (tanto as comidas secas, quanto os erans são "cortados") e depois sua transformação ao serem limpos, cozidos e oferecidos, ou seja, quando essa comida é cozida ou assada e depositada nos assentamentos. Essa etapa é denominada Iyanlé. Em cada etapa dessas, uma sequência ${ }^{68}$ de toadas é mobilizada e repetida nas etapas subsequentes. As cantigas do momento do corte dos animais e do ebó não são repetidas, ocorrem apenas uma vez em cada obrigação. E por fim, há ainda a saída do ebó. Como veremos, ao término do axexê, esse é o momento de maior tensão nas obrigações.

Como notou José Jorge de Carvalho (1984, p. 159), ebó é qualquer comida oferecida aos orixás e ancestrais. Essa comida pode ser "seca", quando são oferecidos alimentos à base de leguminosas, grãos ou industrializados (queijos, doces, refrigerantes, cervejas), e mesmo carnes de boi ou peixe que são comprados; e ainda podem ser eran (carne), que são os animais abatidos ritualmente. Para Pai Paulo, ebó seria ainda tudo o que se compra para as obrigações: “Tudo aquilo que você compra, galo, galinha, carneiro, é ebó. No momento em que a pessoa já sai pra comprar a lista de coisas, quando Ifá dá o recado, já é um ebó que ela está fazendo.”

Ebó também é o nome dado ao ritual de retirada dessa comida dos assentamentos e sua destinação a um local (em geral, mato, estradas, rios e mar); é a etapa chamada de "saída de ebó". Nesse caso, há uma passagem da comida oferecida e sua transformação temporal que obriga sua retirada do peji e do balé. Como observa a explicação de Malaquias:

Eu abato um animal e ofereço o sangue e a carne cozida ao santo. Ele aceita de bom grado; mas com o passar do tempo o alimento se deteriora, então depois de 48 horas o santo não aceita mais que os alimentos fiquem em contato com ele. A comida

\footnotetext{
${ }^{68}$ A tese de José Jorge de Carvalho (1984) é indispensável para uma compreensão aprofundada dessas toadas e seu encadeamento. Para uma descrição pormenorizada de cada etapa, conferir também a tese de Arnaud Halloy (2005).
} 
tornou-se ebó, e este ebó tem de ser mandado embora imediatamente (Carvalho, 1984, p. 159, tradução minha).

Pai Paulo me disse que esse ebó, quando fica três dias "em cima" do santo, é retirado e passa a se chamar eru, "carrego", que é despachado. A saída do ebó acontece de maneira pública durante o final do ciclo funerário denominado axexê, na presença de todos, enquanto os ebós das outras obrigações de eguns são momentos privados e com pouca assistência. José Jorge de Carvalho nota com precisão como cada obrigação no nagô é seguida por outros rituais complementares, os quais possuem uma dinâmica própria quanto à sua execução.

Durante minha estadia, pude acompanhar diversas saídas de ebó. Se durante uma obrigação a presença de pessoas para auxiliar nos preparativos e oferendas era sempre grande, a saída do ebó é uma etapa quase solitária ${ }^{69}$. Ela envolve o trabalho de retirar dos santos e dos eguns, com as mãos, as comidas ali depositadas em acelerado estado de decomposição.

Entretanto, em alguns casos, o ebó era retirado poucas horas depois de ofertado, a depender do que determinasse o jogo, como algumas obrigações de eguns e, principalmente, como veremos, as de axexê.

Passo agora à descrição de uma obrigação aos eguns. Ela ocorreu ainda em meu período de campo do mestrado, no mês de fevereiro de 2014. Parte desta descrição se encontra em minha dissertação de mestrado ${ }^{70}$.

Encontro Bino sentado em um bloco de cimento colocado junto ao muro, em frente à casa de Iemanjá Ogunté. Pergunto a ele se seu Pai já havia chegado. "Painho ainda não chegou, mas Paulinho [irmão de Bino] foi ao banco ver se o rapaz depositou o dinheiro para a obrigação, quando ele chegar, nós vamos". Aproveito para me sentar ao seu lado e folhear o jornal do dia, que estampa uma vitória do Santa Cruz F.C., time de preferência da maioria das pessoas da casa, bem como do Bairro de Água-Fria, Arruda, e (por que não?) de toda a região norte de Recife.

Aguardamos em silêncio. Eu viria a descobrir ali uma característica bem própria de Bino: por mais que seja extrovertido e de fácil amizade, é muito sério e "não é de falar muito".

\footnotetext{
${ }^{69}$ No entanto, de acordo com meus amigos do nagô, as pessoas que participaram da obrigação deveriam estar presentes também na saída do ebó.

70 (Filho, 2015, p. 85-94.)
} 
Como nos conhecíamos há pouco tempo e não encontrava um assunto para iniciar uma conversa, fico calado. Enquanto Paulinho não chega, contemplo a rua de paralelepípedos e suas casas geminadas.

Paulinho chega, Bino coloca o dinheiro na carteira e partimos para o Mercado de Águafria, "para comprar as coisas da obrigação". O mercado de Água-fria é o principal centro comercial do bairro homônimo. Em Recife, onde praticamente todo bairro possui um mercado público, tais espaços abrigam pequenas bancas que vendem desde comidas a roupas e acessórios. No mercado de Água-fria, o diferencial está na venda de produtos religiosos que abastecem o grande número de terreiros da região. Logo na entrada, uma banca de artigos religiosos se destaca por conta de seu grande fluxo de clientes. Ali paramos para comprar quatro litros de dendê, velas, $\mathrm{obi}^{71} \mathrm{e}$ folhas frescas. Bino, crescido naquele bairro, conhece praticamente todos no mercado, desde os vendedores das barracas aos clientes habituais. "Bença, padrinho", diz uma senhora para ele; "Deus te faça feliz", ele responde enquanto retribui o beijo na mão que ela lhe deu. Do lado de fora, compramos na "barraca do Galego" as galinhas e os frangos, ou "pintos", já que em Recife a palavra "frango" é utilizada para designar homens gays, e é evitada pelos ogans. Bino negocia o preço: $\mathrm{R} \$ 35,00$ para os pintos e $\mathrm{R} \$ 30,00$ para as galinhas. A guiné ${ }^{72}$ está na faixa dos $\mathrm{R} \$ 50,00$, mas está em falta na barraca do Galego. Bino paga os animais e avisa que um rapaz irá buscá-los em breve.

Partimos para o beco em frente ao mercado, onde se adensam pessoas entre as diversas barracas de frutas e verduras. Bino compra cebolinhos e seguimos para um mercadinho atrás das barracas, para comprar o que ainda falta. Compramos dois quilos de feijão fradinho, ovos e um pinto de granja. Terminada a lista de compras, paramos em um "come em pé"73, na esquina da Estrada Velha de Água-Fria com a Avenida Beberibe. Bino pede uma cerveja e dois copos. É perto do meio dia e a dona da barraca pede alguns conselhos pra Bino. Diz estar preocupada com os filhos e pergunta se o fato de usar uma roupa roxa na sexta-feira pode ser prejudicial. Bino responde que não, compra um maço de cigarros e acende um. Mal acendera o cigarro e um homem aparentando uns quarenta anos aparece pedindo um cigarro. Bino entrega dois e ele pergunta se o pai de Bino já chegou. Bino diz que não e me apresenta a ele: "este é Inaldo, é gente nossa lá do Sítio".

Outro homem pede um cigarro para Bino, que lhe entrega dois enquanto me diz, "uma hora dessa e painho ainda não chegou". Um homem carregando um carrinho de mão aparece e

\footnotetext{
${ }^{71}$ Noz de cola.

72 Galinha d'angola.

${ }^{73}$ Pequenos bares construídos nas calçadas de Recife.
} 
pergunta pra Bino se tem mais alguma coisa para levar para casa de Tia Lú. Bino oferece-lhe uma cerveja: "veja um litrinho para ele", diz para a dona do estabelecimento. Enquanto o homem bebe, o celular de Bino toca e ao interlocutor ele avisa que seu pai não chegou ainda, mas as coisas já estão compradas e, à tarde, vão fazer a obrigação, e depois seu pai irá retornar para a pessoa. Desliga o celular e me diz: "painho não chegou ainda e fulano já tá cobrando, e eu que tenho que resolver as coisas enquanto isso...”. Pergunto se seu pai costuma atrasar quando vem de João Pessoa: "depende do motorista que vai buscar ele, mas sempre dá uma atrasada, porque às vezes ele precisa esperar outros passageiros, ou então painho paga a viagem cheia e vem direto, mas fica caro". Pergunto para Bino o que faremos agora: "vamos para casa adiantar as coisas, porque quando ele chegar já vai ficar agoniado querendo fazer as coisas logo".

Pai Paulo finalmente chega a casa. Bino já preparou parte da comida a ser utilizada no ebó prescrito pelo jogo como solução do problema do consulente. Pai Paulo cumprimenta todos e se dirige ao quarto de seus filhos.

Ao retornar para o barracão, Pai Paulo segue em direção ao balé, quarto dos mortos, um espaço contíguo à cozinha dos santos. Esta última consiste basicamente em um ambiente com um fogão à lenha disposto paralelamente, em um pequeno corredor, e à entrada do balé. Como Ifá determinou no jogo, a obrigação daquele dia era para os eguns. Pai Paulo seguiu para o balé e fez os cumprimentos necessários aos antepassados. No balé, só entram as pessoas de confiança da casa ou que tenham ligações de parentesco de santo (filhos de santo) ou de sangue com eles. Quando uma pessoa entra em obrigação, deve primeiro fazer uma oferenda para os eguns e depois para os orixás. Além dessas obrigações, os eguns são cultuados em datas específicas e sempre que determinarem o jogo de Ifá, como no caso aqui retratado.

Como apresentei na introdução deste capítulo, Pai Paulo é o Alapini da família, posto mais elevado da hierarquia do culto dos eguns. Se na Bahia o título de Alapini é um "cargo", uma posição ritual hierárquica dentro do culto dos eguns adquirido pelo tempo de iniciação e pela chefia de vários terreiros, em Recife ele vem por "herança familiar":

"Meu bisavô Adifabola, o gerador familiar era Alapini de Oyoba. Ele veio para o Brasil a troco de fumo e cachaça, enganado dentro de um porão de um navio negreiro. Ele faleceu no dia 04 de dezembro de 1901, com mais de 100 anos. Quando ele chegou aqui deram o nome dele de Sabino Felippe da Costa. Como era forte, trabalhador e inteligente, os senhores obrigavam-no a manter relações sexuais, para nascerem crianças fortes, inteligentes $e$ trabalhadoras. Caso ele recusasse, levaria chibatadas no pelourinho. Ele foi 
um Sacerdote com todas as regalias... mas morria de saudades e de dor por estar longe dos seus familiares que ficaram na África, do outro lado do oceano. Quando morreu, ele já havia abandonado a adoração aos orixás e eguns, e era mulçumano, como os malês."

Essa é uma noção amplamente disseminada nos terreiros da família. Recentemente, um antigo filho de santo de Pai Paulo, filho carnal de um importante juremeiro da cidade, trouxe alguns ojés de Itaparica para fazer obrigações no balé de sua casa. Ele mesmo teria se "iniciado" como ojé. Bino sobre isso me disse: “aqui ojé não é cargo, é herança. Está no sangue [diz batendo no antebraço]. Quem está trabalhando ali dentro no balé, é ojé. Nós não fazemos ojé. Ojé se nasce.”.

Em Recife, todos os homens que oficiam as cerimônias de eguns são chamados de ojés. São considerados ogans, se tocam em festas, ou axoguns, se cortam os animais em obrigações. Não se trata, portanto, de um cargo ou de uma função específica dos candomblés, como em suas contrapartes de outros lugares.

Do lado de fora, escuto a longa evocação que acompanha as batidas de ixan (bastão de madeira que é usado para invocar os eguns) no chão. Além de Adifabola, seu bisavô, ele clama pela presença dos ancestrais enumerando-os "pelas hierarquias", dos mais antigos aos mais recentes, e saúda também eguns "famosos" em Recife, como Ato e Aro e outros nigerianos da família de seu amigo "africano". Com isso, segundo as contas de Pai Paulo, ele chega a saudar, aproximadamente, mais de 100 eguns.

Desse modo, não apenas os ancestrais consanguíneos são passíveis de serem transformados em eguns no balé, mas todos os ancestrais da família de santo são incorporados às longas invocações aos eguns. Pai Paulo acrescentou à sua lista, além dos eguns de seus ancestrais consanguíneos, os eguns de Ajibola, por serem "africanos de dentro do culto"; incluiu também antigos sacerdotes do mundo do candomblé recifense. Nessa operação, ele contabilizava aqueles que teriam mais força e poderiam "interceder" mais pelos vivos. Sobre isso, ele explicou a Arnaud Halloy:

Para o pai santo, a lista de antepassados listados está longe de ser limitada apenas aos ancestrais biológicos, mas também inclui pessoas - até personagens! - ilustres que, aos olhos do pai santo, constituem a genealogia da adoração. Além disso, a lista em questão pode apresentar variações de um líder de culto para outro. $\mathrm{O}$ fato é que certas pessoas serão inevitavelmente citadas por todos. Esses ancestrais inevitáveis são os ancestrais dos atuais fiéis ou personagens que desempenharam um papel fundamental na história da família. Os mais citados são Ifátinuké (Tia Inês), Alapini (pai de Pai Adão), Opê Otanam (Pai Adão), Ojo Okunrin (Zé Romão) e Oje Biyi (Malaquías). Todos os participantes atuais, e não apenas os líderes do culto, mantêm um sentimento de familiaridade com esses ancestrais, o que pode ser explicado por vários fatores:1) 
por sua onipresença nas invocações da obrigação de egum, mas também em todos os rituais em que geralmente são recebidos no início da cerimônia. A invocação dos ilustres ancestrais mencionados acima também pode cumprir uma função ritual específica, qualquer obrigação de Balé começa com uma longa saudação aos antepassados, onde o nome de cada um deles é falado em voz alta pelo pai de santo encarregado da cerimônia. Essa lista também é repetida durante várias toadas que compõem o repertório do Balé. Uma vez perguntei a Paulo se ele conhecia cada uma das pessoas mencionadas. Aqui está a resposta dele: Eu não os conheço todos, mas meu avô os conhecia, e meu pai também ... Os que eu chamo, essas pessoas vieram da África, se uniram como escravos. Mas a todas essas pessoas acrescentei os avôs e bisavôs de Ajibola, que são Obolí, Abiqué, Nemomatú ... Há Obe Kunle, dono do Obaluayé, a quem eu adoro, assim como Oyá Bebi, minha tia que me deu. Há também Aji Muda ou Oje Lade, que é Martiniano ... Há Majé Baçã, mãe de Martiniano, Oyá Togun, pai de Martiniano, Otolu Bioca, pai de tia Vicença, Ifá Tairo, e que viveu um relacionamento conjugal com Tia Inês... Odo Akambe, que é o avô de Eustáquio, pai de Bomboche... Tem Ato Aro, que é o pai dessa "velha"... Dizem que ele é o egum mais forte de Pernambuco... (Halloy, 2005, p. 330).

Mãe Lu sempre se referia a esses outros eguns como "vindos no mesmo barco", ou seja, africanos que teriam chegado a Recife na mesma embarcação. Sem dúvidas é uma narrativa que remonta aos horrores da escravidão e o terrível tráfico de pessoas. Há também um componente dessas narrativas que pode se relacionar ao trânsito intenso da comunidade de africanos libertos ocorrido na segunda metade do século XIX, entre Recife, Salvador e Lagos, na Nigéria. Há toda uma bibliografia sobre esses africanos libertos e suas famílias e o intenso trânsito entre eles ${ }^{74}$. Idelfonso, por exemplo, conta que sua tataravó Tayo Gululu, uma nigeriana que participou da primeira geração do Sítio, filha de Ibeji, Iemanjá e Orixalá, seria a única entre os membros de sua família que não quis retornar para a Nigéria após a abolição. Nas palavras dele, ela dizia: "vou ficar para cuidar dos meus irmãos que aqui estão". Ela faleceu em meados de 1950 e hoje é cultuada como um importante egum da rede da família nagô.

Retornemos à obrigação. O amigo nigeriano que solicitou a obrigação é oriundo de Abeokuta. Ele e Pai Paulo se conhecem há 20 anos e são muito próximos. Foi ele quem intermediou a obrigação daquele dia. Como era recorrente nesses casos, ele passou a incumbência para Pai Paulo (como dito anteriormente, é comum que um confirme o jogo do outro, ou seja, que o jogo de Pai Paulo referendasse ou complementasse o jogo de seu amigo). Nesse caso específico, Pai Paulo jogou para a moça em questão e o jogo determinou a realização de uma obrigação para os eguns e um assaro (comida feita com inhame cozido e amassado e carnes de galinha ou boi) para Exu.

\footnotetext{
${ }^{74}$ Sobre esse ponto, ver, entre outros, Verger (1987); Reis (1989) e Parés(2018).
} 
"Eu preciso invocar muito bem os ancestrais para eles ajudarem a mulher, eles são do outro lado do Atlântico, [por isso] minhas invocações precisam atravessar o mar", Pai Paulo comentou sorrindo ao sair do balé. Sua camisa estava empapada de suor.

Nas obrigações do balé, os eguns masculinos comem carneiros e galos; os eguns femininos, ovelhas e galinhas. Além disso, todos comem caranguejos, bebidas, acarajés, assaro (comida de inhame com carne seca), acaçás, e assadaka (uma bebida feita com acaçá dissolvido em água e mel)

Durante as invocações, Bino chama Paulinho para entrar com o carneiro que será imolado para egum okurin (egum macho) e pede para que eu e outro rapaz peguemos os galos. Os animais se seguiram em meio às invocações de Pai Paulo. Nesse ínterim, ele pede que Bino ligue para o amigo nigeriano para confirmar a lista de nomes que deve incluir nos pedidos para obrigação. Bino passa o celular para mim e pede que eu os anote, já que "Ele fala enrolado e não consigo entender direito". Eu igualmente falho na transcrição exata dos nomes. Enquanto passo a lista de nomes, Pai Paulo comenta rindo: “com essa quantidade de nomes, os eguns vão se confundir".

Enquanto Paulinho preparava os animais maiores, Rosenbrique e Bino iam depenando as galinhas e galos. Pai Paulo sentou-se na cadeira de balanço branca segurando o ixan, símbolo máximo de Oya e dos Eguns ${ }^{75}$, e pediu para que eu pegasse outra cadeira para ele esticar as pernas. "Elas estão muito inchadas, quando eu viajo ou fico muito tempo sentado, elas ficam do tamanho de uma alfaia [tambor de maracatu]". Indicou com a cabeça outra cadeira, eu a peguei e coloquei ao seu lado para conversarmos: "Quando eu chamo meu avô [Pai Adão], eu sinto um arrepio muito forte. Mesmo agora [com o calor elevado] eu sinto aquele frio que vai chegando do meu lado direito, eu sei que é meu avô". Pergunto-lhe se ele chegou a conhecer o avô. Ele responde:

"Não alcancei meu avô vivo, mas eu tenho uma ligação muito forte com ele.

Quando eu falo Opewatanan! [diz aumentando o tom de voz], eu sinto aquele arrepio, aquele frio do meu lado. O que sei do meu avô era o que meu pai [Malaquias] me falava - eu e ele éramos muito próximos. Com dez anos eu já dobrava os ilus. Meu pai cantando e eu tocando. Vinha gente me ver tocando e ele dançando. Ele dançava muito, que nem meu avô. Quando ele

\footnotetext{
75 "Os ixãs estão originalmente ligados ao culto aos mortos, como é o caso de Uída no Benin e da Bahia no Brasil" (Verger 2000: 496). "Eles também são essenciais no culto dos eguns em Recife" (Halloy, 2005, p.529).
} 
cantava assim [imita segurando as sílabas finais das frases], aí eu segurava no ilu, ía mais lento. Aí, na resposta eu acelerava. A gente era muito ligado.

Uma vez perguntaram para os africanos se eles sabiam o que significava Opewatanan. Eles não entenderam. Aí, com Ajibola eu disse: Opewatanan. E eles falaram 'ah sim, ope watanam, pronto, agora deu, isso eu sei o que significa'. Antigamente, em Recife, tinha nas ruas das Águas Verdes uma casa de adoração de egum, era a casa de Oya. Quando o mais velho morria, o outro assumia, é assim que era pelas hierarquias. Quando meu avô Adão morreu, a casa fechou. Além de pai de santo e babalâ, ele era oje $e^{76}$ nessa casa que os africanos antigos cultuavam Oya. Quando um chefe morria, o mais velho assumia. Ele tinha quatro ajudantes, e ele assumiu o culto por ser o mais velho. Depois que morreu, aquilo se acabou. A rua foi derrubada para a construção de uma larga avenida. Ele morreu em 1936 e eu nasci em 1941, não o conheci, mas conheço-o pelas histórias que meu pai me contou.

Quando eu era criança, estava brincando no Sítio, eu vi o retrato do meu avô em meio às árvores, num canto do mato. Eu saí correndo chorando, e meu tio Zé Romão ralhou com as mulheres 'não é pra deixar os meninos brincarem ali!'. Eu vejo meus ancestrais em sonho. Ainda criança, eu sonhei com um homem gordo, bem pretinho, parado na porta do peji cantando para Xangô [nesse momento, Pai Paulo canta a cantiga]. Acordei e falei pro meu pai: Pai sonhei com um homem assim, cantando pra Xangô. 'Era meu pai', ele me disse. 'Meu pai cantava assim, entoado"77. Meu pai [Malaquias] era muito entoado. Eu canto nem 50\% do que meu pai cantava, e ele dizia que perdeu muito do jeito que meu avô cantava. Quando eu era jovem e estava cantando, meu pai me dizia: 'cante como seu pai canta!'. Ele achava que eu estava imitando meu tio Zé Romão.”

Pai Paulo se alongou nas invocações, enquanto seus filhos, Bino e Paulinho, iam colocando as comidas cozidas nos eguns. Como a lista era grande e minha caligrafia difícil de entender, Pai Paulo pediu que eu fosse lendo os nomes, em voz alta, das pessoas pelas quais os eguns teriam de "interceder" na Nigéria.

\footnotetext{
${ }^{76}$ Sacerdote especializado no culto aos ancestrais.

${ }^{77}$ Entoado pode ser entendido como cantar afinado, mas não só isso, pois é também uma categoria nativa para dizer que a pessoa canta bem, que, além de ser afinada, sabe como, o que e quando cantar. É algo que não se ensina, é necessariamente algo que já vem com a pessoa.
} 
Ao terminar a obrigação, ele pega um prato branco com oito búzios e joga para saber se os eguns aceitaram a oferenda. No nagô, esse jogo é sempre utilizado para confirmar uma obrigação; com um número reduzido de odus, ele permite, além da confirmação, precisar qual recado as divindades ou ancestrais transmitem antes e após a obrigação: "O certo é jogar depois de três dias para saber se a oferenda foi realmente aceita. Mas nesses casos já dá pra ir adiantando o recado", me disse Pai Paulo, enquanto manipulava os oito búzios e jogava no prato. Pai Paulo diz que os eguns confirmaram, mas que seu amigo iria querer que ele confirmasse também com os dezesseis búzios, para saber qual odu respondeu na confirmação e poder ter certeza "da graça alcançada".

No outro dia pela manhã, encontro Pai Paulo sentado em sua poltrona, na entrada do barracão. Outra cadeira posicionada em frente é usada como mesa. Sobre ela está uma bandeja de madeira redonda com búzios encrustados em sua extremidade.

Pai Paulo pede para que eu segure em uma mão um pedaço de osso e na outra um búzio: "mude eles em suas mãos enquanto você os coloca atrás de você, de modo que eu não saiba onde cada um está". Obedeço a esse comando e ele começa as invocações de Ifá. Fala de maneira apressada e num tom de voz quase inaudível. Em um rápido movimento joga os búzios na bandeja. Ele os recolhe e joga novamente. “O búzio está na mão direita?”. Abro a mão em sua frente e lá está ele. Pai Paulo diz então que está "positivo" para a nigeriana. Apesar das dificuldades que aparecerão para ela alcançar seu objetivo, "pode ser que ela ganhe", ele diz enquanto recolhe os búzios e olha firmemente para a bandeja. Entrega-me novamente o búzio, eu repito o processo e ele retorna às invocações, lançando novamente duas vezes os búzios. "O osso está na sua mão esquerda?". Confirmo, mostrando o osso em minha mão esquerda, e ele diz que está difícil o jogo para ela, "não está vendo bem". O odu que saiu foi oworin, que indica dificuldades, conforme ele explica:

"O certo era uma obrigação para uma e outra obrigação para outra. Mas ele inclui na obrigação de uma os pedidos de todas aquelas pessoas e isso não dá certo. Eu avisei ontem e você está vendo agora que eu estava certo. Não dá pra fazer uma obrigação e pensar em muitas pessoas. Tenho que concentrar naquela que está pedindo, para aos eguns aceitarem seus pedidos, senão fica confuso, dá invocação e as coisas não dão certo."

\section{Maracatu}


Um dos períodos de maior influência dos eguns é o carnaval. Pai Paulo gostava de contar que as obrigações para os eguns eram feitas no sábado, seguindo a tradição da família: "as oferendas para os eguns eram no sábado do carnaval. Os despachos eram após três dias, quando o pessoal podia brincar o carnaval. Por isso, meu pai e os irmãos dele criaram a Troça Carnavalesca o Bagaço é Meu, porque só brincavam o final da festa (risos)".

O sábado de carnaval é o dia principal para se fazer uma obrigação aos eguns. Ela pode ser desde uma simples limpeza de carnaval, com comidas secas e bebidas, até mesmo uma grande obrigação, com carneiro, ovelha, cabra e bode.

Em outros terreiros da família, as pessoas que possuem uma vinculação mais forte com a Jurema também fazem obrigações antes dos dias de festa. Quase todas as agremiações carnavalescas tradicionais possuem algum tipo de vinculação com os terreiros de candomblé e Jurema e com suas divindades e espíritos. Caboclinhos, troças mistas, afoxés e, em especial, os maracatus. Assim, grande parte delas implementa uma boa quantidade de obrigações nos dias precedentes ao carnaval.

Os maracatus são grupos percussivos compostos de reis e rainhas, baianas, lanceiros e os batuqueiros. Seus principais instrumentos, na atualidade, são as alfaias, agbês e gonguês. Os maracatus tradicionais em Recife são chamados de "maracatu nação" e as pessoas se referem aos seus grupos como "minha nação". Esses maracatus diferenciam-se daqueles do tipo "folclóricos", grupos percussivos compostos majoritariamente por pessoas brancas e sem qualquer vinculação religiosa. Assim, o que permite um maracatu ser uma nação é o fato de possuir as Calungas, bonecas de madeira que são os eguns protetores do maracatu. Quando uma Calunga recebe uma obrigação, a exemplo das pessoas, diz-se que ela está "de quarto" ou recolhida.

Assim, as bonecas do maracatu são suas Calungas, ou seja, a personificação de antepassados ligados à história do Maracatu e responsáveis por sua segurança durante o carnaval. De certo modo, elas personificam esses ancestrais e são também o próprio maracatu personificado.

As calungas são eguns e, portanto, são guardadas com muito cuidado e zelo durante o ano. Apenas pessoas feitas no santo podem manuseá-las. Além disso, as mulheres que carregam as bonecas devem realizar uma obrigação para sairem com as calungas no carnaval. A personificação do Maracatu pelas bonecas é tal que as pessoas costumam comentar que, ao morrer um dono de maracatu, seus descendentes podem acabar com o maracatu por não saberem "cuidar" das calungas. Assim, muitos maracatus antigos foramforam destinados a 
museus da cidade. Um caso bastante comentado é o de um jovem filho de santo que retirou as calungas de um desses antigos maracatus, pertencente à sua bisavó, do museu e as levou para casa. Além disso, esse rapaz tinha por costume gravar secretamente as invocações dos eguns e reproduzi-las em casa. Ele, então, alojou as calungas em seu quarto e ficava invocando os eguns. Pai Paulo teria descoberto isso em jogo e o alertado sobre o risco que ele corria. De acordo com os praticantes do candomblé, não se pode cantar as toadas dos eguns sem conhecer seu fundamento, pois cantar é trazê-los para perto de si e é preciso toda uma técnica ritual para que eles retornem ao seu lugar. Os cantos são o próprio território por onde se movem os eguns. Segundo consta, o rapaz não seguiu o conselho e continuou com essa prática até que um dia teria "endoidado" e passado a viver pelas ruas de Água-Fria.

Marcio, ao comentar sobre a Calunga de seu maracatu, me disse que ela tinha um "brilho no olho" diferente, ressaltando ainda que ela é uma "coisa viva". As calungas são vivas e várias pessoas me narraram que as escutam, e Marcio conta: "Um dia antes do desfile, eu olhei pra ela e ela me disse "não se preocupe, esse ano é nosso!"”. Demais sinais da vitalidade das bonecas é a capacidade de olhar, enfeitiçar, seduzir e até mesmo enlouquecer alguém.

A família possui um Maracatu, o "Raízes de Pai Adão", fundado em 1998. No início, esse maracatu era composto quase exclusivamente pelos membros da família consanguínea e filhos de santo. Com o passar dos anos, em decorrência de divergências e brigas, grande parte das pessoas da casa de Mãe Lu saíram desse maracatu e hoje participam do Maracatu Estrela Brilhante, no Alto José do Pinho. Sendo assim, esse segundo maracatu - um dos mais tradicionais de Recife - atualmente abriga grande parte da família - mas essa relação com o Estrela não era totalmente nova. Para além dos conflitos que motivaram a migração de grande parte das pessoas, a mudança se deu por valores estéticos - as pessoas admiram a qualidade do Baque do Estrela - e também pelas relações de amizade e parentesco. Junior Boto reside com sua esposa e filhos em uma casa de propriedade de sua sogra, Nina, próxima à sede do grupo. Junior e seus filhos são membros ativos desse maracatu, e grande parte de seus filhos de santo são jovens batuqueiro. Além disso, sua sogra sempre foi muito próxima da atual dona do Estrela Brilhante, e uma de suas entidades de Jurema participa da rede espiritual da nação.

Retomo agora a etnografia de uma obrigação para as Calungas do Maracatu Raízes de Pai Adão, realizada por Pai Paulo, bem como seu desenrolar nos dias de carnaval. 
Pai Paulo parecia bastante chateado nos dias que sucederam o carnaval.

"O maracatu perdeu!", disse.

Pensando que essa derrota o abatera por ser um maracatu de sua família, que inclusive leva o nome de seu avô, e, sabendo que na juventude ele fora uma pessoa importante no mundo dos carnavais em Recife, tentei consolá-lo com frases vagas de motivação: "Não fique triste, não, Pai Paulo, o carnaval é assim mesmo, ano que vem tem mais".

Aparentando profunda contrariedade com minha resposta - totalmente equivocada por razões óbvias - , Pai Paulo responde: "Não se trata de carnaval, não. O jogo, após a obrigação no balé para as bonecas, deu Ogunda como valor determinante. Isso quer dizer que poderia ter até vitória, desde que as pessoas não brigassem!”.

No Maracatu Raízes de Pai Adão, as calungas são duas mães-de-santo da genealogia da família: Vicentina, uma Calunga de Tia Vicência, velha mãe de santo do Sítio, filha de Iemanjá, filha de João Otolu e mãe de santo de Mãe Lú; e Tia Alexandrina, filha de santo de Oxum e mãe-de-santo de Zite. A elas é concedida, anualmente, uma obrigação no balé, nos dias que antecedem o carnaval.

Embora o maracatu seja "da parte dos eguns", ele se relaciona também com os orixás, conforme fora dito a Halloy:

\footnotetext{
O rei e a rainha têm de ser 'feitos'... O rei deve ser um negro, alto e elegante'. Assim, entre as condições necessárias para ocupar os mais altos cargos honoríficos do Rei e da Rainha do maracatu, enfrentar iniciação religiosa. É a mesma coisa, mas em menor grau, para encarnar os outros personagens da corte real, como a Dama Passo, que tem a responsabilidade de levar o Calunga, embaixador, etc. (Ibidem, p. 746).
}

Bárbara me contou que foi confirmada primeira princesa do maracatu, que sua coroa é preparada e ninguém pode usá-la - ela mesma tinha de seguir uma série de resguardos (não beber, não ter tido relações sexuais na véspera) para participar do carnaval, assim como as damas do passo que também devem cumprir uma série de resguardos ao carregarem as calungas.

O Maracatu Raízes é dirigido pelo sobrinho de Pai Paulo, Itaiguara, filho de seu irmão Cicinho. Eu tive a oportunidade de vê-lo fazendos os acertos da obrigação das calungas para o carnaval, dias antes da festa.

“Tio, faremos sábado a obrigação das calungas", falou Itaiguara, ao que Pai Paulo respondeu: “Tá certo, então. Você já comprou os bichos?”. “Já, o rapaz vai trazer no sábado de manhã. Meu pai vai vir também para ajudar", respondeu Itaigura. "Tá certo, negão. Você já 
combinou com os meninos?", Itaiguara confirma com a cabeça. "Então até sábado", disse Pai Paulo.

Os filhos e sobrinhos de Pai Paulo são grandes percussionistas em Recife, tocando em vários maracatus e blocos afro da cidade. Júnior Boto, por exemplo, foi mestre do Raízes no começo de sua existência. A filha de santo de seu irmão Cicinho era a Rainha do Maracatu e Bárbara era a princesa. Com o passar dos anos, no entanto, uma série de divergências afastou grande parte da família, que acabou se espalhando por outros maracatus da Zona Norte de Recife.

Esse era o caso de Cianinha (Jaciane), sobrinha de Pai Paulo e irmã de Itaiguara. Ela fora por muito tempo a "dama de passo" do maracatu, uma das mulheres que carregam as calungas durante os desfiles. Cianinha era dama da boneca Alexandrina, a boneca de Oxum. Naquele dia, ela tinha ido cortar o cabelo de Pai Paulo, quando ele falou:

"Eu avisei a Itaiguara, olha, pode até ganhar, deu positivo, mas tem que tomar cuidado com briga. E fulano brigou com sicrano, uma confusão medonha. Eu não posso fazer por todo mundo, cada um tem de fazer o seu. Eu invoquei, passei mais de uma hora invocando, cantando. Agora, ele não acredita, sempre pergunta se precisa fazer aquilo mesmo, se adianta alguma coisa."

Cianinha responde: "Pois é, Tio Paulo, por essas que eu me afastei do maracatu. Eu saí e não apanhei da boneca, pois Dona Alexandrina entendeu. A boneca fala comigo, mesmo eu não estando mais no maracatu, ela fala comigo, eu avisei Itaiguara, mas ele não acredita. Disse que eu estou muito 'obsediada'”. Cianinha ligou a máquina de cortar cabelo e pediu que Pai Paulo retirasse a camisa, e continuou a falar:

"Ela me avisou que não era para fazer obrigação só no Balé, que ela era filha de Oxum também e que tinha de ser dada uma obrigação para o orixá. Mas ninguém me escutou. As alfaias tinham de comer, os batuqueiros têm de ficar de preceito também. Mas eles querem? Eles não conseguem ficar de preceito, ficar sem beber ou mulher no carnaval."

Pai Paulo assentiu com a cabeça enquanto retirava com a mão os cabelos que caíram em sua nuca depois que Cianinha passou a máquina, e só então continuou: "Eu avisei que os orixás tinham de comer, deu no jogo que Oxum e Iemanjá estavam precisando comer também, mas ele disse que estava sem dinheiro para dar essa obrigação". 
Assim, a depender do maracatu e das entidades que o compõem, o grupo deve realizar, além das obrigações para as Calungas, obrigações para os orixás aos quais as Calungas se filiam, bem como, se houver, para as entidades da Jurema. O maracatu Estrela Brilhante, por exemplo, além das obrigações para suas Calungas, rende obrigações aos orixás. Seu baque é consagrado a Cangaruçu, um mestre de Jurema, que também deverá receber obrigações nas semanas que antecedem o carnaval. O maracatu possui ainda um caboclo como protetor espiritual, é Taguaracy, entidade de Nina: "Quando o maracatu sai, meu índio fica no chão (recebendo oferendas), é ele quem protege", me explicou a mãe de santo.

Essa não é uma característica apenas dos maracatus. Em uma das obrigações que participei, uma mãe de santo da rede de santo da família reclamou com Guara que o afoxé de seu marido só "comia dinheiro", isto é, nunca ganhava nada e só o endividava. O marido dessa senhora pegava inúmeros empréstimos com agiotas para manter o afoxé, dado que a subvenção da prefeitura do Recife mal cobre as despesas com tecidos e adereços. Há ainda o pagamento aos integrantes, transporte e alimentação. Mas, principalmente, o Estado não cobre as despesas com as entidades que protegem o afoxé ou maracatus e demais agremiações carnavalescas. $\mathrm{O}$ marido, tentando se justificar, disse: “o Afoxé é de Iansã, aí já viu. Tem de comer no balé e no santo. Eu queria largar, mas o santo dela [se refere a mãe de santo] não deixa..."

Os ancestrais possuem uma íntima relação com os maracatus. Pai Paulo me contou em diversas ocasiões sobre essa relação entre os maracatus e os antigos africanos escravizados em Recife:

“Esse negócio de maracatu, não é maracatu que fala não![Não, Pai Paulo?] Não, é que os brancos ouviam os africanos dizer 'muraca-tuca' e entendiam maracatu, 'olha aquele maracatu de negros'. E também não tinha esse negócio de Pátio do Terço não, o certo era na Igreja Nossa Senhora do Rosário dos Pretos. Era lá que os escravos tinham um dia por ano de folga. Eles se reuniam, lembravam dos que ficaram (em solo africano) $e$ desabafavam todas as amarguras, do sofrimento, da escravidão e das saudades dos seus entes queridos. Então eles rufavam os tambores até as duas horas da madrugada quando acabava a reunião e todos voltavam para os seus engenhos, os que ficavam ou fugiam eram perseguidos a cavalo e chicoteados ou mortos. Quando chegava certa hora, eles falavam: 'muracatuca', o que significa 'vamos parar e se espalhar'. Os estudantes que gostavam de assistir o evento, que não entendiam as palavras, chamavam de maracatu. Um dia falei pra Ajibola e ele: 'Ah sim, sim, muraca tuca, reunir e espalhar'," 
Todo ano, na segunda-feira de carnaval, à meia noite, ocorre uma cerimônia no carnaval no Pátio do Terço, centro histórico de Recife. Em meio a antigas casas coloniais, muitas deterioradas pela ação do tempo e descaso do poder público, projeta-se a Igreja do Pátio do Terço. Durante o dia, é intenso o movimento do comércio popular em seu entorno, mas, à noite, poucos se aventuram a caminhar por ali, mesmo no carnaval. Os maracatus e afoxés encontram no Pátio seu principal e praticamente único palco durante os dias de folia.

Na segunda-feira de carnaval, os maracatus enfileiram-se nessa estreita rua. Não é um desfile completo dos componentes, apenas uma corte diminuta: Rei e Rainha, estandarte e as damas de passo que, responsáveis pelas bonecas, vestem-se igualmente a elas. Esse é o dia de saudar os eguns. Próximo ao palco, do lado esquerdo, encontra-se a casa que pertenceu a Sinha e Yaya, um dos primeiros terreiros de nagô em Recife. Sua última dirigente foi Badia, que contava com ajuda do pai de Pai Paulo, Malaquias e principalmente de José Romão, para cuidar das obrigações. Com a morte de Badia, seu irmão de santo, Raminho levou os centenários assentamentos dos orixás dessa casa para seu terreiro em Olinda. É ele o pai de santo que dirige as invocações aos eguns.

Esse evento é conhecido como Noite dos Tambores Silenciosos. À meia noite, as luzes da rua se apagam. As alfaias silenciam e o que se escuta é apenas o som dos ilus do nagô batendo em um ritmo rápido e intenso "chamando" Oya. Raminho canta a primeira toada, saudando os eguns. Nas calçadas lotadas, pessoas ligadas aos terreiros respondem. Fogos estouram no céu. Alguém cai em transe, Raminho canta para Oya, as pessoas começam a bater palmas, pombas são lançadas. As luzes se acendem, os maracatus voltam a tocar as alfaias e o carnaval continua.

Próximo ao Pátio do Terço, existe um amplo largo em frente à outra igreja barroca, o Pátio de São Pedro. Nele são realizadas as apurações dos desfiles de carnaval de Recife. No carnaval de 2014, o maracatu vencedor foi o Estrela Brilhante, maracatu de Márcio e Júnior Boto. O "Raízes", por sua vez, caiu para o grupo de acesso. Houve uma grande confusão envolvendo os membros do Estrela Brilhante e os do Maracatu Porto Rico. Leandro, à época mestre do Raízes, foi apartar a briga e acabou estampando a primeira página dos jornais de Recife que cobriam a apuração. Isso gerou uma série de comentários e fofocas entre as pessoas ligadas aos maracatus e, por conseguinte, aos terreiros.

Alguns dias depois da apuração, encontro Pai Paulo de bom humor na frente da casa de Mãe Lú. Como de costume lhe tomo a benção e ele diz com satisfação: 
[Não estava sabendo]

Não vai mais cair, com aquela confusão toda da apuração. Itaiguara me contou que nenhum maracatu vai descer e que vão ficar todos no grupo especial. Eu estava muito chateado mesmo com essa queda. Eu tinha visto no jogo um resultado positivo mesmo, Ogunda como valor determinante, podendo até ganhar, falando de vitória. Aí, quando perdeu, fiquei aborrecido, cheguei até mesmo duvidar das invocações, e você viu, caiu, mas não perdeu, ficou. Já é uma vitória.

[O senhor estava mesmo chateado...]

E não era? Mas terminou que deu tudo certo, ainda mais que ficamos na frente do maracatu X. Eu não ia ficar para trás de fulano (pai de santo X, que cuida do maracatu X) dentro do Balé, ele é um menino perto de mim, não estava nem na guimba do pai dele quando eu já ajudava meu pai nas obrigações (risos). Quem é bom já nasce feito..."

\section{Ciclo Funerário}

Passo agora à descrição do ciclo funerário de uma antiga mãe de santo ligada à rede de parentesco da família de santo. Acompanhei, ao longo desses anos de pesquisa de campo, ao menos cinco sepultamentos e treze axexês. Presenciei desde cerimônias e enterros de pais e mães de santo - sendo o mais impactante e difícil o de Pai Paulo - até de jovens filhos e filhas de santo. A descrição do sepultamento, abaixo, ocorreu em janeiro de 2017, na cidade de Olinda.

O carro funerário mal despontou na pequena rua do acesso ao terreiro e os parentes que ali estavam começaram a chorar. Muitos se mantinham com os olhos distantes, outros conversavam amenidades, mas o choro contido rompeu diante do fato que a ausência do corpo ocultava. Ela tinha falecido.

Na porta principal do terreiro, seu irmão e seu único filho esperavam em pé. O primeiro, ojé mais velho, segurava um ixan e saudou os eguns: egum gbo matorio o! Todos responderam em coro: hey hey hey! Os ojés, na grande maioria os sobrinhos da mãe de santo, seguiram até o carro da funerária e retiraram o caixão. Levantaram-no três vezes e seguiram em direção ao interior da sala da casa. Antes de adentrar ao espaço, o ojé iniciou uma longa saudação aos 
eguns. Sua voz embargou e as lágrimas escorriam em seu rosto. Conseguiu se recompor e só então ordenou que o caixão entrasse.

Em volta do ataúde, estavam somente os homens. Três jovens ogans foram ao balé buscar o trio de tambores bata, os tambores de Oya. Mais uma saudação aos eguns e os homens iniciaram o grave canto dos mortos. O ojé mais velho, segurando o ixan na cabeceira do caixão, foi seguido pelos mais velhos da família. O número de homens era tão grande que não coube nenhuma mulher naquele momento na sala. Os cânticos preencheram o espaço e quase não era possível àqueles mais distantes do caixão ouvir a sutil mudança de uma cantiga para outra. Toda a sequência de cânticos ${ }^{78}$ aos eguns foi entoada, iniciando com: "Àgò nílé àgò lóde o" (Carvalho, 1993, p.178), primeiro a ser entoado em qualquer obrigação aos eguns e terminando com Obêrê Obêrê Eku ô Obêrê Obêrê Ojarê Oinxê Manuaê Oinxê Manuaê (Carvalho, 1984, p. 576) ${ }^{79}$. Ao fim dessa última toada, a sequência é encerrada, excluindo-se do conjunto aqueles cânticos utilizados para "mandar os eguns embora".

O ojé, então, convocou as mulheres para perto do caixão, pedindo que se aproximassem e iniciassem as rezas: um "Pai Nosso", uma "Ave Maria” e um "Salve Rainha”. Todos fazem o sinal da cruz em suas testas e rezam. Finalizadas as rezas, o ojé se senta em uma cadeira na entrada da sala, segurando o ixan - ele não soltaria o objeto em nenhum momento até o corpo partir. Os ojés mais novos saem e vão "beber o morto" numa barraca próxima. No interior da sala, as pessoas se aproximam do caixão, beijam a testa da mãe de santo falecida, choram e relembram histórias.

Ao se aproximar o horário do sepultamento, o ojé ordena que os três jovens peguem os batás: é a senha para informar que a segunda etapa do ritual irá começar. Os homens se aproximam novamente. A exemplo da chegada do corpo, o ojé se encaminha para a cabeceira do caixão. Nova saudação, agora pedindo que o egum vá embora "Em nome de Deus, dos bons espíritos de luz, aos eguns de nossos pais e irmãos que já partiram", dizendo que ele "cumpriu sua missão" e, se for a vontade de Deus, que ele volte para ajudar sua família e fazer caridade. A sequência de cânticos aos eguns é novamente entoada. A diferença é que agora ouvimos também aquelas dedicadas a despachar os eguns, encerrando-se com a cantiga: "Koríko be

\footnotetext{
${ }^{78}$ Sequência de cânticos 01 ao 34 do livro Cânticos Sagrados do Xangô do Recife, de José Jorge de Carvalho (1993).

${ }^{79}$ Sobre essa última toada, ela vincula uma série de atos rituais a depender do contexto em que é executada. No velório, ela marca a abertura do caixão e o fim da primeira parte dos cânticos. Ao final do velório, ela sinaliza o fechamento do caixão. No axexê, como veremos, é a toada que encerra a última parte pública da obrigação, enquanto, nas obrigações de balé, é específica de um ato ritual privativo aos homens.
} 
koríko bẹ̀ẹ Ánikán gb'ore Ėjilá aláṣo Koriko be koriko bẹrẹ̣" (Carvalho, 1993, p.189); mas excluindo-se aquelas que apenas deverão ser cantadas já dentro do cemitério.

O caixão é levantado por três vezes e então conduzido ao carro da funerária, onde as coroas de flores são dispostas. Uma longa fila de carros segue o cortejo, cortando o bairro do subúrbio e seguindo para o cemitério de Santo Amaro, um dos mais tradicionais da cidade.

Ao chegar ao cemitério, o caixão é colocado em uma estrutura ao som dos cânticos: “Áṣeșe áṣeșe ọdọ baba l'à ḿbọ" (idem, p. 188), mudando no verso o termo baba (pai) por iya (mãe) e segue em direção ao sarcófago onde será depositado. O caixão é empurrado pelos ojés, os batas e agbes seguem atrás e um novo cântico é entoado: "Iyami axexê, Baba mi axexe, axexe okua agba ${ }^{80}{ }^{80}$

Uma longa fila de pessoas vestidas de branco segue a triste procissão. O volume é ampliado pela presença daqueles que não compareceram ao velório e decidiram se despedir e homenagear a mãe de santo. Muitas pessoas que estavam em outros sepultamentos do cemitério param para acompanhar o trajeto, atraídas pelo som dos batas e agbes e pela força dos cantos vigorosamente entoados pelas filhas e filhos de santo.

Ao chegar ao sarcófago, há uma estrutura de concreto semelhante a uma grande parede. Nessa estrutura estão as lápides das pessoas enterradas, quase todos jovens negros. O caixão é novamente aberto e os familiares e filhos de santo podem se despedir pela última vez do corpo. $\mathrm{O}$ ataúde é enfim depositado na estrutura em forma de gaveta. O último cântico é entoado: “Ṣóṣoṣó epulu Bàbá Làmẹsẹ mibọ ẹpẹtì" (Carvalho, 1993,p.189); enquanto os coveiros lacram a abertura do sarcófago, finalizando apenas quando o último tijolo é cimentado. Sobre o concreto fresco, é escrito o nome da mãe de santo e a data de seu sepultamento. Um último Pai Nosso e mais uma Ave Maria são rezados. As pessoas seguem para fora do cemitério e, ao passarem pelo portão principal, passam um pouco de água sobre as mãos e rosto e jogam o conteúdo para trás, saindo de costas para o cemitério.

Os jovens ogans e alguns membros da família seguem para as barracas em frente do cemitério, formando uma grande mesa. Cervejas são distribuídas, as pessoas almoçam e, a exemplo do velório, relembram momentos marcantes e histórias divertidas da família e da mãe de santo. Uma sobrinha joga a "milhar do bicho" com o ano do nascimento da mãe de santo. As pessoas brincam, sorriem. Conhecidos que passam pela região ou retardatários do enterro

\footnotetext{
${ }^{80}$ Essa sequência de cânticos foi introduzida no repertório dos eguns por Pai Paulo e pode ser encontrada no livro "Os Nagô e a Morte", de Juana Elbein dos Santos (1986, p.232). Além desses, Pai Paulo introduziu o cântico: "Aiyé atí ikú ôkan náa ni", como notou Arnaud Halloy: "toada composta de uma invocação extraída do livro 'Ifá: o orixá do destino"” (1995,p 83; 94); e cujo significado é dado com ênfase por Paulo: "A vida e a morte são a mesma coisa!" (Halloy, 2005, p.78).
} 
se juntam ao grupo. Quase todas as barracas de comida e bebida estão lotadas pelos presentes no enterro. A moça que tinha jogado "no bicho" ganha uns quatrocentos reais e as pessoas comemoram: é um recado do egum. Com o dinheiro pedem mais cervejas até esgotarem o estoque da barraca.

Após o sepultamento, as pessoas deverão assistir uma missa de sétimo dia. É comum a produção de santinhos, com fotos dos falecidos vestidos com roupas de santo e algum salmo ou oração que era da predileção do homenageado. Todos comparecem vestidos de branco, e camisas que estampam a foto do falecido poderão ser confeccionadas e distribuídas para os mais próximos.

\section{VARIANTE}

Estava sentado com Pai Paulo, na frente do terreiro, quando chegou um filho de santo de Pai Paulo para contar que um antigo filho de santo de seu tio José Romão havia falecido, e o enterro seria dentro de algumas horas. O rapaz me convida para acompanhá-lo. Pai Paulo pergunta se éramos parentes para ir ao cemitério, ao que o rapaz argumenta que iria para se despedir, já que o pai de santo era uma pessoa de sua extensa rede de relacionamentos de santo: pai de santo da madrinha da casa do padrinho de Jurema dele. Pai Paulo, ainda contrariado, assente com a cabeça. O rapaz, para reforçar seu convite, diz: "É bom para a pesquisa dele também". Eu concordo e Pai Paulo diz que, se fosse por essa razão, eu deveria ir, mas o certo era que minha ida somente se justificaria se eu fosse parente do falecido.

Despedimo-nos de Pai Paulo e seguimos ao cemitério. No caminho, meu amigo me conta que esse antigo pai de santo morreu com aproximadamente 90 anos. Era um filho de santo de Ogum, filho de José Romão, mas que tinha passado anos na antiga nação Congo, hoje desaparecida em Recife, cujo principal pai de santo era Apolinário. O Ogum do falecido era famoso por ser possuidor de uma cobra, chamada pela divindade de Ajao. Quando em terra, ele dançava com o animal nos braços, o que assustava as pessoas. Segundo meu amigo, esse Ogum "vinha meio como mestre": ele dava consulta, falava com as pessoas e não se parecia com os santos de agora, que mal falam. Esse senhor possuía ainda um forte mestre de Jurema, "QuebraPedra", cuja força fazia com que vivesse em pé de guerra com o orixá, ao longo de toda a vida desse pai de santo. A divindade e o espírito "disputavam" o comando do terreiro e da cabeça do pai de santo, a tal ponto que um dia o mestre pegou a cobra de Ogum para que ela picasse o braço do pai de santo em retaliação por este não lhe dar igual atenção. 
Chegando ao cemitério, reconhecemos o velório pelas pessoas vestidas de branco. $\mathrm{O}$ caixão do antigo pai de santo já estava para sair. Ao lado, algumas de suas filhas carnais entoavam hinos neopentecostais. Meu amigo me avisa que parte da família havia se convertido, o que teria gerado muitos desentendimentos e problemas, demonstrando preocupação com o prosseguimento da casa. Após os hinos, um pastor inicia um pequeno sermão. Antes que ele termine, o ojé responsável segue para a cabeceira do caixão, junto a três ogans, um com o batá e dois com agbes na mão. O pastor finaliza sua pregação e o ojé assume a direção da cerimônia com uma saudação em voz alta aos eguns.

Nesse momento, os filhos de santo se aproximam do caixão. O ojé coloca suas mãos sobre a cabeça do falecido e diz: "Quem é maior do que Deus?". "Ninguém”, as pessoas respondem. "Quem pode com Deus?" "Ninguém”, ele mesmo responde. "Salve Nosso Senhor Jesus Cristo", diz, e pede que rezem um Pai Nosso e uma Ave Maria; pede que Oya leve o egum para um lugar do seu merecimento, deseja que a terra lhe seja leve e se lembra da trajetória do pai de santo, da amizade que tinha com seu pai, também falecido, e inicia os cantos dos eguns.

Uma filha de santo, que até então chorava copiosamente, incorporou Iansã. Rapidamente suspenderam a santa e os cânticos continuaram. O cortejo seguiu então para o túmulo recém-cavado, onde depositaram o caixão. O ojé cantou duas ou três cantigas de jurema que o pai de santo gostava de cantar. Um outro pai de santo entoou novamente duas cantigas de egum e os presentes se dispersaram. A caminho da parada de ônibus, passamos pelas últimas pessoas de santo saindo do cemitério; elas passavam moedas no corpo e jogavam para trás quando cruzavam o portão. Um grupo de coveiros, habituados a enterros de pessoas de santo, já esperavam por esse ritual na entrada do cemitério e se divertiam em pegar as moedas de maior valor e se gabar com os colegas.

Retornando ao terreiro, Pai Paulo me avisa para ir saudar os eguns no balé. Recomenda que lave meus olhos, rosto e mãos com um amassi, pois eu havia chegado do cemitério. Sentados em frente ao terreiro, ele me pergunta como tudo passou e se tinha sido bom pra minha pesquisa. Consenti e comecei a dar detalhes. Ele então me disse que antigamente não se cantava para os eguns quando uma pessoa era enterrada; a tradição se iniciou com seu pai, Malaquias, que teria sido a primeira pessoa a cantar para se enterrar uma pessoa. Foi no enterro de Dona Santa, antiga rainha do Maracatu Elefante, sepultada em um dia de obrigação para Xangô, na casa das Tias do Pátio do Terço. Segundo Pai Paulo, ao sair do terreiro para ir ao cemitério, Sinhá teria ordenado ao seu pai: "Vá, mas volte, porque meu Xangô ainda vai comer, ela não é minha parente! ". 


\section{AXEX̂̂}

O relato etnográfico abaixo diz respeito ao axexê de uma filha de santo da família, ocorrido no dia dois de novembro de 2018. Ela era filha de uma importante mãe de santo, madrinha de muitos iniciados na casa de Mãe Lu e sogra de um dos seus sobrinhos.

$$
\text { *** }
$$

A jovem mulher morreu em decorrência de uma crise de asma. Ao chegar ao pronto atendimento, o médico teria ministrado uma dose maior do que o recomendado, o que a levou a uma parada cardiorrespiratória. Nesse instante, mais um grave erro médico ocorreu. Ao "intubar" a paciente, os médicos perfuraram sua traqueia, o que a levou para um estado de hemorragia seguido por um período de coma. Ela veio a falecer em menos de quarenta e oito horas após ter dado entrada no pronto atendimento por uma crise de asma! Esse relato se faz necessário porque muitas pessoas com quem convivi sofreram inúmeros crimes como esse. Os chamados "erros médicos" são comuns nas narrativas dessas pessoas. Grávidas que sofreram "ligaduras de trompas" sem saber, parturientes que tiveram de ser operadas novamente por terem esquecido linhas de nylon em seu abdômen, diabéticos que receberam remédios com glicose. Enfim, incontáveis casos de simples erros em medicamentos até casos extremos que provocaram mortes. Não possuo dados sobre o número de pessoas negras que sofrem com erros médicos como um todo, mas a própria observação durante o trabalho de campo com a família permite constatar o racismo médico que as pessoas dos terreiros sofrem em seu cotidiano.

Outro aspecto mais indireto do racismo que afeta a saúde das pessoas de terreiro com as quais eu convivo são as decorrentes da alimentação à qual estão submetidas. Grande parte da alimentação é oriunda de produtos alimentícios de baixíssima qualidade, mais acessíveis para essa população por conta dos baixos preços e por isso constituindo grande parte de sua dieta. São produtos com altíssimo índice de sódio, açúcar, transgênicos e gorduras hidrogenadas que impactam suas vidas com doenças crônicas, como diabetes, pressão alta, problemas cardíacos. Quase todas as pessoas do terreiro sofrem com ao menos uma dessas doenças crônicas, causas recorrentes dos óbitos de seus familiares e amigos. E basta caminhar no centro comercial de Água Fria para ver as pessoas de meia idade ou idade avançada com marcas corporais destas doenças. 
O axexê da jovem foi marcado para o dia dois de novembro, cerca de quarenta dias após sua morte. A família da filha de santo contou com a colaboração da rede de casas da família de santo. Foram oferecidos dois carneiros (um aos eguns de Malaquias e outro para o egum de Pai Paulo), duas ovelhas (uma para o egum da filha de santo e outro para o egum de Tia Zite, que era a mãe de santo dela), uma cabra para Oya, um bode para Exu e um grande número de galos e galinhas.

A mãe carnal estava muito aliviada por poder, enfim, realizar o axexê de sua filha "para dar um pouco de conforto para a alma dela". A moça faleceu um dia antes de sua filha mais nova completar um ano - ela e seus outros dois filhos ficaram sob a guarda e responsabilidade da avó. Ela dizia que sentia o egum da filha por perto, já que "com duas crianças pequenas ela não tem paz". O axexê seria a cerimônia que abreviaria o sofrimento do egum, ao mesmo passo que reduziria o risco de uma influência negativa sobre as crianças. "Meu netinho não consegue dormir, acorda assustado. Às vezes o egum quer o bem, mas não sabe como fazer e acaba prejudicando."

Logo pela manhã, me dirijo ao terreiro para ajudar nos preparativos. Uma grande tenda branca foi armada na lateral da frente do terreiro. Os filhos de santo traziam bebidas e comidas para ajudar no almoço. Nos dias de axexê, o alimento principal é feito à base de peixes e frutos do mar. As galinhas e outros animais abatidos são distribuídos somente ao fim. Os peixes são um dos alimentos principais dos eguns.

Dois jovens se dirigem a casa da mãe de santo para buscar o café da manhã que será oferecido para os participantes. Uma bacia de alumínio é colocada no canto da mesa, onde cada pessoa deverá colocar um pouco da comida que serviu para si mesma "para comungar com o egum". Após o café da manhã, tem início a cerimônia.

O axexê, a exemplo das obrigações no nagô, é realizado em duas etapas: o corte dos animais e a primeira sequência de cânticos aos eguns. A segunda etapa é o iyanlé, que consiste em colocar nos assentamentos parte dos animais oferecidos e outras comidas cozidas. Nesse ponto também são executados os cânticos aos eguns da primeira parte, acrescidos de três cânticos que são exclusivos da etapa final. No axexê, esse último estágio se divide em mais dois: o ritual de despachar o egum e a saída do ebó.

Dois jovens do Sítio trouxeram o velho trio de batás dessa casa, provavelmente os mais velhos em uso do Brasil. São tambores cônicos com duas peles em suas extremidades, comuns em Cuba e na Nigéria. No Brasil, os terreiros nagô são os únicos que ainda os utilizam nas cerimônias, em especial nas de eguns. 
Os jovens afinam os instrumentos, atividade que consiste em desencordoar o aro que fixa a pele e esticar as cordas novamente, à maneira das alfaias do maracatu. Enquanto eles finalizam essa tarefa, outro grupo de rapazes ajuda a descarregar e separar os animais. As mulheres se ocupam do almoço e dos preparativos. Tio Cinho, irmão de Mãe Lu e único filho de Malaquias ainda vivo, chega para iniciar a obrigação. Atualmente ele é o pai de santo da casa e o membro mais antigo da família. Ele está cego em decorrência da diabetes e é guiado ao balé por um filho de santo.

Tio Cinho começa as invocações aos eguns. Os animais são trazidos para perto do balé. As mulheres se concentram na parte oposta no barracão. No punho esquerdo de todos, é amarrada uma fina fita feita de mariwo, palha de dendezeiro. Tem início o ritual. Dentro do balé, Pai Guara é quem comanda seu desenvolvimento. Tio Cinho fica sentado em uma cadeira de balanço na porta de entrada; em suas mãos está o ixan e é ele quem detém a autoridade de controlar os eguns. Os primeiros animais são imolados para Exu. Estão todos em silêncio. Após esses animais serem oferecidos, Tio Cinho inicia com os cânticos aos eguns. Os familiares começam a chorar e o ambiente fica mais grave e pesado. Os batás tocam o ritmo solene dos eguns: as primeiras cantigas são muito "pesadas" e o momento é de seriedade.

Um ojé traz os animais de Oya: a sequência agora ganha uma maior animação, os batas são tocados com muito vigor, as pessoas batem palmas acompanhando a execução dos ogans. Gritos em louvor a Oya explodem no salão: "epa heyyy”. As mulheres agora se levantam e ficam de costas para o balé com a cabeça baixa. Como a parede é pequena para o volume de pessoas, elas se apoiam nas costas das pessoas que estão na parede. O cântico termina e elas voltam a se sentar.

Uma ovelha é trazida e Pai Guara ordena que os familiares "batam a cabeça para a ovelha", pedindo para o Egum da filha de santo ter paz e tranquilidade e que "vá para um bom lugar ao lado de Deus" e dos outros eguns. A mãe, o irmão e filhos se ajoelham e cada um ao seu tempo coloca a testa na cabeça do animal. A outra ovelha é para o egum de Tia Zite, mãe de santo da falecida. Mãe Lu e Tio Cinho repetem o ato de "bater cabeça" para a ovelha. Tio Cinho recomeça os cânticos e os familiares agora choram copiosamente.

Guara solicita que eu traga o carneiro para o balé. Uma folha de cajá é oferecida ao animal que a mastiga. Uma corda é enrolada em seu focinho. Guara agora dirige o canto, um canto solene em louvor aos Eguns masculinos: em cada repetição do canto, ele modifica o nome do egum, saudando os mais antigos até chegar ao egum de Pai Paulo, Ifatogun. Cada vez que os nomes são ditos, as pessoas respondem Awo. Os sacrifícios terminam. 
Os ojés saem do balé. Uma roda é formada no barracão. Ao centro, os homens e, nas bordas, as mulheres. Após a sequência de cânticos, Mãe Lu inicia um pai nosso e uma Ave Maria. Todos dão as mãos. Ela acrescenta uma salve rainha e uma oração a Santo Antônio: "Desde que meu irmão morreu, eu rezo pra Santo Antônio, foi um pedido dele".

Após essa etapa, Pai Guara pede que as mulheres entrem na cozinha para retirada dos animais do balé. Os homens agora vão limpá-los e tratá-los separando as partes que vão para os eguns (coração, fígado, rins, pulmões, parte das costelas e dos ossos da coluna) e o que será distribuído aos presentes. As galinhas serão depenadas e receberão o mesmo tratamento de separação de partes que os demais bichos.

As mulheres organizam a distribuição do almoço. Novamente as pessoas deverão colocar numa vasilha para o egum parte do que serviram para si mesmas. As pessoas se espalham pelo terreiro para almoçar. A maior parte vai para a frente da casa e para debaixo do toldo. O muro do Sítio serve como sombra onde podem se sentar ou deitar. Até o cair da noite, conversam e bebem cervejas e refrigerantes. Tio Cinho e Guara permanecem cada um com um ixan constantemente em uma das mãos.

Por volta das 18 horas, tem início a segunda etapa da cerimônia. As comidas e bebidas já foram depositadas no balé, bem como a bacia com parte dos alimentos compartilhados com as pessoas. Guara pede para que dois rapazes depositem dois sacos de areia no centro do barracão. Eles espalham a areia para formar dois círculos concêntricos, como um oito desigual, uma parte maior e outra menor. Nas bordas são inseridas dezesseis velas. Esse é o egum. Os ventiladores são desligados. Os ojés agora sentam próximos à parede do balé, de frente para a entrada do salão. No centro da figura, senta-se Tio Cinho, Guara está à sua direita. Bino, Junior Boto e Paulinho formam um círculo próximo ao egum. Atrás dele sentam-se os tocadores dos batás, enquanto as mulheres permanecem no canto oposto. O restante dos homens fica no lado oposto ao das mulheres.

Dois homens saem do balé e colocam um grande alguidar de barro com um mingau de farinha ao lado do egum. Novamente os cantos aos eguns começam; dessa vez todo o repertório é cantado a pleno pulmões. Todas as pessoas batem palmas e vibram a cada invocação. Tio Cinho inicia os cânticos. Após uma sequência, é a vez de Pai Guara e cada um dos ojés irá cantar uma parte da sequência.

Quando começa o cântico “Obêrê Obêrê Eku ô Obêrê Obêrê Ojarê Oinxê Manuaê Oinxê", os homens, do mais velho ao mais novo de santo, pegam um copo do mingau e depositam no centro do buraco na areia. Depois é a vez das mulheres, a ordem é inversa, das 
mais novas a mais velha, terminando com Mãe Lu. Por fim, Guara pede para que as mulheres entrem na casa e fechem todas as portas e janelas. Ele joga os búzios para saber se algum orixá da filha de santo deseja “ficar". Apenas Xangô aceita e o santo deverá ser cuidado pelo irmão dela, que também é de Xangô. Os outros irão com o carrego. As luzes são apagadas, tudo é recolhido e armado em um grande embrulho. Esse é o ebó que o jogo determina que seja levado ao mar. Enquanto Bino bate em todas as paredes da casa com um ixan, um grupo de ojés sai carregando o ebó para o carro.

O restante fica no terreiro, todos em silêncio. Guara e Tio Cinho continuam sentados na entrada com os ixans na mão. O terreiro fica em suspenso por mais ou menos quarenta minutos. O grupo retorna, Guara entrega uma quartinha com água; cada um coloca um pouco nas mãos e a joga sobre a cabeça em direção à rua. Os homens vão até o balé saudar Exu. As luzes são acesas e as mulheres retornam ao barracão. Mais uma cantiga é iniciada, todos dançam em círculos, homens e mulheres, cada um em sua roda. Todos de mãos dadas rezam novamente um conjunto de preces. Por fim pedem benção aos mais velhos: o axexê acabou.

A cada ano, deverá ser feita uma renovação dessa obrigação ao egum, pelo menos até completar um ciclo de sete anos. A diferença dessas obrigações para o axexê reside no fato de que nessas renovações não há a representação do egum na areia, pois apenas na primeira cerimônia isso é feito. Outra diferença é que a pele do carneiro e da ovelha, despachada nesse primeiro axexê, também não receberá nenhum tratamento ritual específico. Discuto esses pontos na conclusão do capítulo.

\section{OS TERRITÓRIOS DOS MORTOS E SEUS PERCURSOS}

Em 1997, Pai Paulo teve um infarto seguido de um acidente vascular cerebral (AVC). Seu médico lhe disse que, para ajudar em sua recuperação, era preciso ler em voz alta e fazer anotações. Um amigo, então, lhe deu um livro sobre Ifá, onde ele lia os odus, anotando-os em um caderno. Segundo contava, “essas coisas eu já sabia, eu já tinha isso, mas quando eu li o livro, essas coisas se encaixaram, foi com isso que me curei”. Essa cura, por intermédio do aprendizado do jogo de Ifá, lhe deu um novo nome, Ifatóògún, que significa "Ifá é meu remédio". "Fui curado por Ifá", ele diz. Essa cura possibilitou que Pai Paulo fosse considerado uma dos maiores especialista em métodos divinatórios de Recife, em especial por dominar com maestria diferentes técnicas oraculares. Após sua morte, Pai Paulo deixa de atuar como um intérprete dos recados dos orixás e eguns para transformar-se, ele mesmo, em um recado. $\mathrm{Ou}$ 
ainda, passou de alguém que ouvia os recados para falar por intermédio deles. O caso etnográfico abaixo ilustra essa transformação.

$\mathrm{O}$ evento aqui descrito se passa poucos dias antes do meu retorno ao terreiro, em dezembro de 2016 - ou seja, no período anterior ao falecimento de Pai Paulo. No entanto, seus desdobramentos ocorreram após sua morte. Em todo esse período, Pai Paulo foi uma presença ativa na solução do problema por meio do jogo.

Mãe Lu me contou que, após uma sequência de quedas de Obiorossum durante o jogo de búzios para uma filha de santo, Pai Paulo determinou: "Você precisa dar uma obrigação no balé, tem muito feitiço e egum falando para você”. Ainda de acordo com Mãe Lu, foi feita uma obrigação grande no balé para a moça, porque ela estava muito carregada e tinha perdido o emprego: "acho que foi desse dia em diante que meu irmão não se recuperou mais, ele já estava debilitado", ela avalia.

A situação da filha de santo não se resolveu após a obrigação, e nesse meio tempo Pai Paulo faleceu. Após um período de luto e restrições religiosas, Mãe Lu me avisa que farão uma obrigação na jurema para a filha de santo. "O jogo dela continua caindo muito obiorossum, e veio um exu falando em um outro odu", me explicou Mãe Lu, dizendo ainda: "meu pai dizia que quando caía esse exu no jogo, poderia ser um mestre da Jurema que vinha falando como exu no jogo para cobrar alguma obrigação".

Mãe Lu sempre fez questão de lembrar que também sabia jogar búzios, tendo aprendido com seu pai Malaquias:

"Meu irmão Paulo joga, ele gosta dessas coisas, sempre foi muito interessado e não é porque é meu irmão não, mas aquele negão sabe das coisas, joga como ninguém. Mas eu sei jogar também, sou filha do mesmo pai. Meu pai, quando estava jogando para alguém, eu estava na casa, ele sempre me chamava, dizia: 'olhe para o jogo aqui, sabe que odu é esse? É tal e o recado é isso, aquilo...' Todos nós aprendemos com ele, ele era muito bom [Emocionada, com os olhos marejados e a voz embargada, ela continuou a lembrar do pai]. Meu pai era muito bom, me ensinou muita coisa. Eu mesma, quando Bino não tá aqui, peço agô e jogo para saber o que fazer, pra conversar com Iemanjá, né? Nossa mãe, a mãe de todo mundo aqui."

Às sextas-feiras se oferece arroz de Oxalá, ao que sempre se segue um jogo. Naquele dia, já após a morte de Pai Paulo, Mãe Lu pede para que eu entre no peji e busque um frasco de 
perfume que fica aos pés do assentamento de Oxum ${ }^{81}$. Ela pega o frasco e passa em suas mãos e rosto e pede para que as pessoas façam o mesmo. Só então passa a manejar os búzios e invocar os orixás e eguns para que venham auxiliar nas respostas do jogo de búzios.

No sábado seguinte àquele jogo, houve uma grande obrigação no terreiro para os mestres da Jurema, exus e pombagiras. Toda a família carnal da filha de santo estava presente no terreiro e se envolveu na preparação da obrigação.

Como vimos, no balé, as mulheres devem estar totalmente apartadas do manejo com os eguns. No território da jurema, por sua vez, elas podem atuar sem nenhuma restrição, pois os modos de lidar com os mortos são distintos. A “aproximação" por um espírito nos rituais aos eguns é algo extremamente nocivo, podendo provocar doenças e assombramentos. No entando, no território da jurema demanda um tratamento específico de incorporação e não raro as pessoas contrastam as experiências da manifestação dos orixás e da possessão pelos espíritos e entidades da jurema. O corpo é novamente acionado como metáfora para essas diferentes texturas espirituais: "a sensação é horrível”, "o corpo pesa, depois ficamos com o corpo pesado, é uma pessoa dentro de você".

Alguns orixás são particularmente avessos ao contato com a fumaça, tomada como sinônimo de espíritos. Em especial, os orixás Oguian e Xangô, e em menor grau Iemanjá. Assim, todos que possuem algum desses orixás, sobretudo os filhos cuja cabeça pertence a alguma dessas divindades, devem cobrir suas cabeças com um pano ou lenço para "não ofender o santo".

Mãe Lu me disse, ao final da obrigação de Jurema da moça, que esperava que as oferendas fossem aceitas e que a ofertante, enfim, arrumasse um emprego. Ressaltou, contudo, que, caso não obtivesse o resultado esperado, levaria a moça a algum centro espírita: "já que nem o balé e a jurema deram jeito, o melhor seria tentar num lugar que cuidasse mais diretamente disso", ou seja, dos "assuntos com os mortos".

Nos dias posteriores à obrigação, Mãe Lu consultou o jogo para saber se as oferendas foram aceitas e quem respondeu, na maior parte das vezes, foi Iemanjá. Ela perguntou se a moça deveria dar um carneiro à divindade; o odu que caiu foi novamente o odu dos eguns, obiorossum. Mãe Lu perguntou, então, se era Pai Paulo quem estava falando, e caiu obixé, um odu de confirmação. Assim, ela perguntou se a moça deveria dar um carneiro para Pai Paulo

81 Considero significativo o uso de perfume de Oxum por Mãe Lu. Essa pequena passagem aponta para uma diferenciação de genêro a ser explorada futuramente em relação ao jogo de búzios, e evidencia também um modo de participação entre Oxum, Ifá e a mãe de santo no momento do jogo. Como veremos, Oxum e Ifá possuem uma profunda vinculação no universo do nagô. 
antes de dar para Iemanjá e o resultado foi positivo. Uma nova obrigação foi acertada para os eguns.

Essa nova obrigação para os eguns foi realizada no balé. Durante o jogo, para saber se a oferenda fora aceita, o egum da mãe carnal da filha de santo avisou que ela não se esquecesse de dar um galo para Ogum, santo da mãe da moça. A obrigação de balé estava finalizada, e Bino consultou o jogo de oito búzios para confirmá-la. Chamou a filha de santo para o salão e antes de pedir que as mulheres rezassem Pai Nosso, Ave Maria e Salve Rainha (rezas utilizadas no fechamento das obrigações de egum), ele disse: "agora a senhora vá e peça para rezar nove missas em nove igrejas diferentes". Mas alertou: "não se esqueça de assistir uma missa em louvor às almas, e deve assistir à missa inteira, entrar por uma porta e sair pela outra”.

Mãe Lu me explica que a igreja é a casa dos mortos, e sempre que vai à igreja, olha para hóstia e vai entregando seus parentes que já morreram: "fiquem aí que agora essa é a casa de vocês!", me disse sorrindo. Eu pergunto, então, por que a igreja é importante para os mortos e não apenas o balé:

"Quando a gente morre, essas divisões não fazem sentido. Morto é morto. Aí não importa se ele era católico, crente, mulçumano, é tudo morto, já morreu. O que você fazia não faz mais sentido. Não tem mais divisão. É tudo morto. A pessoa tem que se apegar a Deus, a gente pede para que os eguns, os espíritos de luz, encaminhem a pessoa pra Deus. Para que ela se conforte e saiba que não é mais daqui. Então uma oração [para] Nossa Senhora, que é mãe, né, para que ela interceda pela pessoa junto ao Nosso Senhor. Eu, velei meu pai, minha mãe e meus irmãos todos aos pés de Maria. No pé daquela santinha ali (uma antiga imagem de Nossa Senhora que foi de seu avô Adão), aos pés de Maria, porque ela quem dá conforto pra gente quando morremos, quem intercede por nossa alma. Meu avô era muito apegado com Maria, todos nós, meu pai sempre fazia o mês de Maria, em Maio. É um período triste pra nossa família, muita gente nossa Maria levou pra perto dela em maio."

“A igreja é a casa das mortos". Essa frase extraída da fala de Mãe Lu e toda sua narrativa atentam para a transformação da pessoa em egum, quando passam a inexistir "divisões" religiosas. Transformação análoga àquela pela qual as mulheres passam, após a morte, no balé: apartadas enquanto vivas, mas entidades com mais força após a morte. Atenta também para o fato de muitos dos antigos pais e mães de santo estarem enterrados nos antigos ossuários das principais igrejas do Recife, em especial a da Nossa Senhora do Carmo, como no caso da família de Mãe Lu, e também 
de outras famílias que compunham as principais casas nagô antigas. Sobre isso, apresento o diálogo da antropóloga Aida Ester Bueno Sarduy a respeito da ialorixá Maria das Dores com o filho desta, e então babalorixá da casa, Roberto:

- Seus ossos são mantidos na Igreja de Nossa Senhora do Carmo. Eu estava pensando em trazê-los aqui, para a casa, mas você tem que passar por uma burocracia tremenda. Tem que passar pela polícia federal. Quando chega uma certa hora...Vou jogar e perguntar se ela quer ficar aqui. Se ela não quiser vir, então ela fica lá na igreja.

Ela era católica?

- Mamãe era católica.

Praticante?

- Praticante. Ela ia muito à igreja, porque aqui todo o povo de Orixá, todos são católicos devotos. Às vezes, em certos momentos, ela dizia que não queria ir à igreja, mas ela ia em silêncio, dizia que ia para ali e voltava depois, ela estava na Igreja (Sarduy, 2014, p. 355).

Pai Paulo sempre relatava a tristeza que sentia em não ter estado presente na exumação de seu pai. Essa tristeza derivava de não ter feito com os ossos de seu pai aquilo que seu pai fez com os ossos do avô Adão. "Meu pai pegou os ossos, lavou com cuidado, passou talco e os guardou", explicou. Várias pessoas da família relatam a emoção que sentiam ao exumar seus parentes. A exumação dos ossos deriva da impossibilidade em se manter o corpo enterrado nos cemitérios. O corpo pode permanecer por até dois anos enterrado e depois deve seguir para um ossuário, no próprio cemitério ou em alguma das inúmeras igrejas que vendem vagas nos ossuários de suas construções.

Esse ato de exumação e acomodação dos mortos em ossuários não é revestido de nenhum ritual específico do universo de cânticos e procedimentos rituais dos eguns, mas há muitos relatos sobre a forte emoção das pessoas ao verem os corpos de seus entes queridos novamente. Os ossos são cuidadosamente lavados e perfumados, passam talco e depois os condicionam em sacos de tecido para serem transportados até o ossuário. No ossuário da família na Igreja do Carmo, estão enterrados Malaquias e Dona Leônidas, os pais de Mãe Lu, além de seus irmãos Sebastião e Zeres. Os ossos de Pai Paulo iriam para esse ossuário, mas, em janeiro de 2019, ao exumarem seu corpo, ele permanecera intacto. Comentando a situação, Mãe Lu disse que ele não tinha partido totalmente e o corpo refletira ainda a força de seu irmão. "Ele é muito forte, o corpo dele não se decompôs. Estava até com as carnes ainda, só as flores que secaram, como aquelas múmias que a gente vê na TV". 
Nesse sentido, e a exemplo do que notou José Jorge de Carvalho (1984, p. 336), as pessoas do nagô não costumam visitar seus antepassados em cemitérios. E como pude perceber, poucos são aqueles que realizam as visitas nos ossuários. Os mortos são evocados e cultuados frequentemente no balé e isso basta, na visão deles, para agradá-los. Não obstante, uma missa, mesmo que executada em igreja diferente daquela em que estejam sepultados, é vista como um modo igualmente válido de entrar em contato com os mortos e cultuá-los de outra maneira. Essa técnica ritual se justifica pela afirmação de que todos eram "católicos também".

A exemplo de outras qualidades que possuía, Pai Paulo sempre remetia "suas heranças", em especial as recebidas de seu avô Adão, como motivações para suas ações e práticas religiosas, como no caso de considerar a Igreja Católica como sua religião:

"Meu avô era muito católico, assim como Tia Inês, que mandou construir aquela capela dentro do Sítio [de Pai Adão]. Ele mandava rezar missas, era da Irmandade do Nosso Senhor dos Martírios. Eu sou católico, isso já está no meu sangue. Sigo essa tradição familiar. Meu avô, no momento de sua morte, disse: 'valei-me minha Nossa Senhora da Conceição'.",

A relação entre o mundo do candomblé e o mundo católico foi traduzida pelos pesquisadores a partir de um sistema de referências sobre o fenômeno do "sincretismo religioso", cuja discussão aparece como incontornável nos diversos trabalhos sobre o candomblé em Recife. Para além dos seus usos teóricos, o tema também é fruto de intensa discussão e elaboração pelos próprios praticantes do candomblé.

Desde Gonçalves Fernandes (1936) e Waldemar Valente (1977), o sincretismo em Recife tem sido lido na chave de uma necessidade histórica dos terreiros em função da escravidão e da imposição do catolicismo. Em consonância com as discussões teóricas da época, René Ribeiro (1978), por exemplo, estava especialmente interessado nos processos de "aculturação" que enxergava como responsável pelo mascaramento dos orixás pelos santos católicos.

A partir dos anos 70, um novo ciclo de pesquisas sobre o xangô do Recife se consolida. Nesses novos trabalhos, procura-se ver o sincretismo não como uma simples influência da "sociedade envolvente", mas enquanto um procedimento ativo das casas de candomblé, a partir do desenvolvimento de uma perspectiva sociopolítica para a análise das religiões afrobrasileiras. Como exemplo, Roberto Motta (1982, p.7) propõe que: “[o] sincretismo não é uma mera concessão de escravos a senhores ou de senhores a escravos, um disfarce usado por um 
negro amedrontado. Pelo contrário, ele possui um aspecto de apropriação legítima dos bens do opressor pelo oprimido".

José Jorge de Carvalho (1984, p. 73) situa o sincretismo dentro do quadro analítico do "sistema de crença" do xangô. Ou seja, os praticantes do culto se reconheceriam como católicos, apesar de "conscientes que suas práticas rituais não seriam bem aceitas por outros católicos". Embora católicos, os membros do xangô não poderiam ser protestantes, pois nenhuma forma de protestantismo aceitaria suas práticas "no lado do xangô". Carvalho ainda relata que a figura de Jesus Cristo seria muito menos proeminente, ao contrário da Virgem Maria, que seria referida com bastante frequência. Para o autor, seria possível falar sobre o xangô como uma espécie de "catolicismo independente de Jesus":

\begin{abstract}
A versão xangô do cristianismo, em suma, obedece ao padrão religioso afroamericano em geral: o culto dos santos. José, um membro da seita, a quem vou me referir muitas vezes nos próximos capítulos, uma vez perguntou-me qual era o santo que eu tinha como um 'santo padroeiro', a quem eu podia rezar e pedir ajuda. Eu respondi que eu não adorava nenhum santo em particular, e que eu preferia me dirigir diretamente a Deus. José não ficou muito satisfeito com a minha resposta e disse que Deus era demasiadamente elevado para que nós seres humanos tentássemos entrar em contato direto com ele. Todos deveríamos, então, abordar os santos, que antigamente 'eram pessoas como nós'. José tocou em um ponto de vista geral dos membros do culto: a necessidade de santos como intermediários entre Deus e os seres humanos. E esta é também a essência de xangô como um culto: a adoração dos santos, ou melhor, dos seus homólogos africanos. Os membros do xangô usam a palavra em português santo mais frequentemente do que orixá (Carvalho 1984, p. 75).
\end{abstract}

Rita Segato (1995, p. 140-142) tende a ver o papel do sincretismo em relação à "mitologia incompleta" do universo do xangô como um preencher de peças de quebra-cabeça de fragmentos mitológicos com sobreposição de imagens e nomes de santos católicos com os orixás. De acordo com a autora, a mitologia nagô seria "fragmentada", dada a experiência traumática da escravidão. Isso impediu que, ao contrário de um "complexo sistema ritual” e do "extenso repertório musical", os mitos fossem na verdade "um conjunto vago e idealizado e nostálgico de noções". Esses fragmentos seriam, então, preenchidos tanto pelo sincretismo quanto por sonhos. Em resumo, Segato propõe que a experiência do catolicismo vem preencher o que é fragmentado e perdido.

Meu objetivo é pensar a relação entre catolicismo e candomblé sem pressupor um tipo de complementação ritual. E se estendermos o modo de funcionamento do mundo dos eguns para o catolicismo? Ou seja, se imaginarmos a partir da textura ontológica dos eguns - no que tange a transformação da pessoa na morte e a inexistência das diferenças religiosas -, vemos que essa condição comum aos mortos seria, de certo modo, uma diferenciação central deles em 
relação aos vivos, para os quais as clivagens religiosas (catolicismo, candomblé, etc.) importam. O catolicismo, e, portanto, sua relação com o candomblé, toma outros contornos.

Deriva desse fato a assunção de que algumas práticas rituais católicas são benéficas para os eguns, tendo efeitos positivos, tal qual o axexê. Se pudéssemos, por um momento, deixar de pensar o catolicismo como um domínio específico exterior ao candomblé e com o qual estabeleceu uma relação histórica na qual seria o elo mais fraco, para pensá-lo do ponto de vista dos eguns, então o catolicismo converte-se em um meio pelo qual essa força pode passar. É dessa perspectiva que, por exemplo, a Virgem Maria deixa de ser uma imagem exclusiva do catolicismo e passa a ter um significado próprio no candomblé.

No decorrer deste capítulo, atentei para certas composições rituais presentes no candomblé nagô, que engajam elementos tidos como católicos (missas, imagens de santos, entre outras) e aqueles de outros domínios tidos como do candomblé (jogo de búzios, ebós, culto aos ancestrais). Como vimos, tais composições entre domínios entendidos como separados (não fechados) não ocorrem em relação apenas ao catolicismo, mas são presentes entre os diferentes contextos e espaços do candomblé nagô.

Quando pensamos a relação dos orixás com os santos católicos, o regime de participações se modifica, pois a natureza do que se relaciona é de outra ordem. Os orixás são de natureza diferente dos eguns, o que configura uma certa relação que, por sua vez, é diferente daquela entre santos católicos e orixás, ou santos católicos e eguns. Portanto, não é possível traduzir essas relações como de um mesmo regime de equivalências, tal qual a noção mais ampla de sincretismo pressupõe ao tratar da convivência de diferentes territórios religiosos.

Essa impossibilidade de equivalência é resultante da própria natureza das coisas comparáveis. Pode-se estabelecer uma associação figurativa entre divindades e santos católicos por meio de características, mas não há um procedimento de adição de forças entre os orixás e os santos católicos. Todo o vocabulário formulado pelas pessoas para explicar a relação entre os santos e orixás é o da diferenciação. Essa diferenciação nos permite vislumbrar um tipo de reversibilidade entre os dois pólos dessa "oposição". Assim, pode-se dizer que os "santos" serviriam como um "fundo" para os orixás e que, igualmente, os "orixás" serviriam como um "fundo" para os santos, de acordo com o que se apresenta enquanto figura na narrativa. Contudo, o mesmo não acontece em relação aos eguns.

A relação entre os eguns e os santos católicos pode ser pensada de modo análogo à adição da linhagem dos eguns à parte do sangue no contexto da iniciação. Quando uma pessoa, ao se iniciar, adiciona sua genealogia de sangue à genealogia espiritual da casa e de seus 
iniciadores, é promovido um novo corte na sua linha ascendente para a incorporação de outras pessoas. Os santos católicos, por sua vez, permitem uma nova composição ao universo dos eguns. A igreja como espaço comum dos eguns e as rezas de Maria são uma adição de forças ao domínio dos mortos. Essas são composições específicas desse regime de forças que permeiam o mundo da família, conforme veremos no decorrer da tese.

Em uma iniciação, quando o iniciante realiza as obrigações aos eguns, dá lugar à geração de um segmento em sua linha ascendente consanguínea ao serem incorporados os ancestrais espirituais. Do ponto de vista do iniciante, tanto seus ancestrais consanguíneos quanto os espirituais viram um só - todos os espíritos estão trabalhando e atuando por ele. Há mais. Esse conjunto passa a ser transmitido enquanto algo único para os seus descendentes consanguíneos. Por exemplo, não havia qualquer vinculação de sangue entre Pai Adão e Tia Inês (ela era sua mãe de santo), mas na medida em que Tia Inês é incorporada como um ancestral de Pai Adão no culto aos eguns, para os descendentes consanguíneos deste último ela é tão ancestral quanto ele. Dito de outro modo, nas gerações subsequentes a diferenciação entre ancestrais de sangue e rituais é eclipsada, e para seus eguns a diferença é de grau e não de tipo. Por outro lado, a iniciação opera a separação do santo e do sangue porque a pessoa que gera uma vida pela parte do sangue não pode ser a mesma que produz a vida pela parte do santo. Tem-se uma nova composição entre as linhas que, em vez de adicionar os ascendentes espirituais aos de sangue, separa - ainda que momentaneamente - essas linhas e promove uma outra segmentação.

Foi por isso que chamei atenção para as composições específicas do santo e sangue em relação à iniciação no capítulo anterior, e em seguida, para as composições do santo e sangue em relação aos eguns. Se no caso dos eguns, por intermédio do ritual, a relação é de adição e certa indiscernibilidade entre a linha de santo e a linha de sangue, na iniciação o ritual deve produzir a diferença entre o sangue e o santo. Não se trata somente da separação de substâncias por meio de um ciclo ritual. A importância dessas composições passa pela diferença de natureza das próprias divindades e entidades que requerem, cada qual, tratamentos rituais específicos. 


\title{
Capítulo 3 - O PeJI
}

\author{
"O legba se instaura transversalmente em: \\ — uma dimensão de destino; \\ — um universo de princípio vital; \\ — uma filiação ancestral; \\ — um deus materializado; \\ — um signo de apropriação; \\ — uma entidade de individuação; \\ — um fetiche na entrada da aldeia, um outro no pórtico da casa, após a iniciação na \\ entrada do quarto... O legba é um punhado de areia, um receptáculo, mas é também a \\ expressão da relação com outrem"
}

(Guattari,1992, p.59)

"recebe-se os que constituem uma série, uma família analógica. Por exemplo, uma filha de yemanjá pode também ser possuída por Oxum, a deusa da água doce, porque as duas deusas estão ligadas misticamente, ou ainda por Xangó, porque Yemanja é sua mãe"

(Bastide, 1945, p.165)

"Mas, como temos visto, toda casa, assim como toda pessoa, deve ter também o outro lado do parentesco. Se o vocabulário ritual é amplamente dominado por termos de parentesco que concernem à filiação, há sempre um espaço decisivo para alianças de outra natureza"

(Barbosa Neto, 2012, p. 201)

No primeiro capítulo, destaquei os processos iniciatórios como um modo de produção de parentesco. Tal produção parte de e contra a relação entre dois termos desse universo de referência: sangue e santo. Por meio do ritual de iniciação, visualizamos o esforço envolvido nesse momento, em que se instaura uma diferenciação em relação à linha do sangue que atravessa o terreiro. Demonstrei, então, quais os efeitos dessa consanguinidade em relação ao próprio ritual. Em certo sentido, este capítulo é um interlúdio entre o primeiro e o quarto capítulo, ao evidenciar os vínculos transmitidos pela herança espiritual, sendo o sangue o principal vetor dessa relação.

\section{O PEJI COMO DISPOSITIVO DE RELAÇÕES}


Neste capítulo, vamos adentrar o espaço dos orixás, o peji. Nele se inscreve a história e a constituição do próprio terreiro. Muitas famílias transformam sua residência em um novo local de culto, a partir da abertura de um peji, quando os orixás dos familiares são instalados e passam a conviver em conjunto numa casa. Como veremos, os orixás vivem nos assentamentos - conjuntos de louça, ferro ou madeira - onde se depositam os otás, pedras que são o próprio orixá. Esses assentamentos são dispostos no peji de acordo com disposições míticas dos orixás, disposições essas traduzidas, em Recife, em termos da proximidade ou distância das relações de parentesco entre eles ou da própria natureza das divindades que incide em sua organização. Esses assentamentos são constitutivos da relação entre pessoas e divindades e presentificam o vínculo entre um iniciado e seus orixás.

Meu objetivo, neste capítulo, é descrever como o peji, enquanto um dispositivo de relações, pode ser observado em funcionamento em sua organização espacial. Nessa dinâmica, evidencia-se um modo de composição entre santos, pessoas, casas e suas histórias. Mais do que sobreposições entre territórios existenciais, enxergamos esse dispositivo como um motor da relação e não um efeito da díade pessoa-santo. Poderíamos inventariar os elementos que constituem os assentamentos, seus aspectos simbólicos e componentes representacionais, e colocá-los à luz de uma grade classificatória, categorizando-os de acordo com um tipo ou grupo de divindades do panteão nagô. Em lugar disso, prefiro atentar para determinadas disposições expressas nas relações entre pessoas e divindades que o assentamento presentifica a partir da materialização desses vínculos.

O pressuposto é que esse modo de relação é condicionante desse universo. Isso se dá tanto na maneira com que esses vínculos entre pessoas e orixás são formados, confirmados e principalmente transmitidos de uma pessoa a outra, de uma geração a outra, a partir das práticas rituais a elas associadas; quanto no cuidado com os assentamentos dos orixás, sua disposição espacial, as oferendas, os cortes de animais, naquilo em que se aproximam e diferem em uma rede relacional de humanos e divindades. Desse modo, recorro à descrição pormenorizada dos assentamentos para narrar um pouco da história do terreiro a partir dessa perspectiva.

Os principais assentamentos e objetos do peji são diretamente relacionados aos seus antepassados. Não somente cada um tem uma história, como também servem como uma lembrança. É isto que os diferencia dos outros assentamentos, pois se sabe que são dotados de certos poderes e imagens que permitem, por meio dos rituais, evocar essa força em benefício da família e dos filhos de santo. 
Os assentamentos, além de vincular pessoas e divindades, são fontes de axé, força que sustenta tanto pessoas quanto casas no universo nagô. Um assentamento é onde um orixá - que é uma força ativa - pode existir/residir. É composto por recipientes contendo um determinado conjunto de ingredientes para ativar e manter esta força; esses receptáculos são dispostos em uma base que suspende os assentamentos e outros objetos a ele relacionados acima do chão, enquanto certos "fundamentos" são enterrados sob o solo onde o peji é construído. São esses ingredientes e elementos que atraem e mantêm as divindades naquele local (cf.Silva, 1995; Rabelo, 2014; Marques, 2016; Barbosa, 2012; Sansi, 2009; Opipari, 2009; dentre outros).

Os assentamentos ganharam um renovado interesse etnográfico. Por um lado, isso se deve a uma mudança da perspectiva teórica sobre o candomblé voltadas a construir teorias etnográficas sobre seu mundo; por outro, por conta da emergência de debates que, ao evitar separar "humanos" e "não humanos", acabam por recusar tomá-los como figura de um fundo social que permeie e explique todas as interações entre esses. Desse modo, os objetos tendem a ser descritos com base na expressividade dos materiais, de suas composições e sua "agência" nas relações. Os debates são fortemente inspirados nas técnicas descritivas contidas na teoriaator-rede (ANT) de Latour (2012) e nos debates melanesianistas sobre relação pessoas-coisas, em especial nos diversos trabalhos de Marilyn Strathern (2012) e Roy Wagner ([1991]2011) e, principalmente, no trabalho de Alfred Gell (1998).

No entanto, devemos evitar aqui o impulso de, ao focalizar esses objetos e as agências nas relações que eles instauram, entender que daí emergiriam as pessoas que os produzem. Não é disso que se trata. Os objetos possuem agência pelo seu movimento, pela complexidade que ensejam, em sua ação e sua multiplicidade.

Em um importante trabalho sobre o tema, Marques (2016) destaca que, no candomblé, pessoa e orixá são feitos mutuamente por meio de um processo contínuo de povoamento de forças a partir da mediação material do próprio assentamento. $\mathrm{O}$ autor alerta que, para acessarmos essas forças e seus agenciamentos (a escolha de agenciamento em vez de agência não é acidental), seria necessário, por parte dos antropólogos, atentarem-se ao próprio processo formativo da matéria. Nessa direção, Mirian Rabelo (2014) define essa relação como "corpo composto" do assentamento. Não obstante, meu interesse neste capítulo é deslocar um pouco o olhar sobre "os modos de existência das coisas" para os "modos de participação" delas no candomblé.

O orixá é seu assentamento, não existindo em abstrato. Sua enunciação sempre o localiza em relação à pessoa que o detém: o Ogum de Marcio, o Xangô de Junior, o Orixalá de 
Paulinho. E há ainda aqueles casos em que a pessoa e a casa conjugam-se no mesmo receptáculo, como a Iemanjá que é simultaneamente a Iemanjá da casa, de Mãe Lú e de seu Pai Malaquias. Essa segmentação, no entanto, não é uma premissa apenas dos "orixás da casa"; outros assentamentos podem conter em seu interior otás de pessoas distintas (como veremos, por exemplo, com os orixás de Junior Boto). Por fim, cabe ressaltar que diferentes qualidades dos orixás podem viver em um mesmo assentamento, como, por exemplo, os diferentes Orixalás, que podem residir e serem cultuados num mesmo receptáculo onde habitam suas versões: Orixalá novo, velho, orixá Oko e outros.

Um indivíduo mais ou menos indiferenciado que torna-se uma pessoa estruturada; um orixá geral que se atualiza em orixá individual, a Iansã de alguém, o Omolu de outrem. Esses orixás individuais têm nomes e características próprias, assim como as pessoas são rebatizadas e vão se modificando a partir da iniciação (Goldman, 2005, p. 9).

Os orixás da casa ou do terreiro são aqueles do fundador da casa ou os membros mais antigos da família, num universo em que a senioridade é um dos princípios que organiza as relações. São esses santos mais antigos que sempre recebem as oferendas em primeiro lugar no decurso ritual das grandes obrigações, como obrigações da casa, incitações e renovações. Isso se repete nas obrigações corriqueiras do dia a dia do terreiro quando uma infinidade de clientes acorre em busca de soluções para seus problemas, ou quando alguém precisa alimentar um orixá sem que tenha o santo assentando; nesses casos as obrigações serão feitas nos santos da casa. Nesses assentamentos serão depositadas suas oferendas, seus papéis com pedidos de cura, de emprego, de soluções para crises conjugais, do cuidado com a saúde ou vida dos filhos. São considerados ainda como santos da casa os orixás que não possuem filhos de santo, mas que são imprescindíveis ao culto, tais como Ossain, Orunmila e Olofin.

Porque existem naquele lugar, os santos devem ser continuamente alimentados e nutridos por meio dos sacrifícios. Como vimos, antes de serem alimentados, os orixás devem estar "despertos" por meio de encantamentos (as chamadas invocações) e ações rituais: aspersão de água, cachaça, pimenta da costa e outros elementos tidos como axé no assentamento.

Esses objetos, como notou Arnaud Halloy (2005, p. 508), “acrescentam por sua mera presença a 'força' atribuída ao assentamento". Tais elementos seriam poderosos referentes daquilo que simbolizam, "as moedas se referem à riqueza, os búzios à África e ao poder do oráculo, os frutos secos com os axés, estes pós pessoais secretamente preparados pelos chefes de culto, aos quais estão integrados" .

Podemos ver aqui um dado fundamental sobre o assentamento: o próprio orixá é uma multiplicidade de elementos heterogêneos dispostos em conjunto - onde o otá é o principal 
elemento, mas não o único, estando junto de búzios búzios, ossos, enfeites. Outro componente é o fio de contas, essencial para a composição dos santos e a materialização dos vínculos entre pessoa e divindade que surge nos assentamentos.

Como vimos no capítulo anterior, a lavagem de cabeça na feitura de uma pessoa é o momento mais importante dentro da tradição nagô. Ajoelhada em frente ao pai e à mãe de santo, a nova iyawo tem sua cabeça gentilmente friccionada com o amassi, os axés, o otá de seu santo e um pequeno colar - os dois últimos ficarão juntos em seu assentamento. Esses colares, também chamados de guias, estão presentes em todos os assentamentos dos orixás, enrolados no formato de rodilhas e colocados sobre os otás. Apesar de não serem tão importantes quanto os otás, esses fios de conta também recebem igual cuidado e zelo. Eles também "comem" e são cuidadosamente limpos após as obrigações - embora não seja tão grave quando, por algum descuido, eles são acidentalmente despachados no ebó. Além de comer junto com os otás, as contas podem, numa emergência ou situação específica, agir enquanto substitutos dos primeiros ao receberem o sangue do sacrifício nessas eventualidades. Recordo uma passagem em que Malaquias explica a José Jorge de Carvalho o porquê disso:

\begin{abstract}
Consideramos o ota como o próprio santo, não só com seu domicílio. Mas algumas vezes chamamos o santo num colar. Aquele colar de Yemanja, por exemplo, está representando Yemanja - como se a pessoa tivesse um ota. Ele não tem ota, então o colar também tem poder, tem algum prestígio, então você sacrifica sobre o colar. Isso quer dizer que não só o ota representa o santo porque há a intenção de invocar, de chamar o santo sobre aquele colar. Seria muito melhor se um ota tivesse disponível, mas como não está, colocamos o colar. De fato, o colar também está ligado ao santo, porque fica na tigela do santo e recebe o sacrifício. Mas deveria ser o ota, porque o povo africano realmente adora o corisco (pedra que cai do céu) (Carvalho, 1984, p. $64)$.
\end{abstract}

Se um filho de santo negligencia seu assentamento, isto é, se não o limpa regularmente, não oferece comida, nem o alimenta com a oferenda de animais, seus orixás "podem ir embora", "se zangar" e até mesmo "castigar" a pessoa. Mãe Lu salienta que é a fé, o amor e o cuidado com o assentamento que contam na manutenção de uma boa relação entre o santo e a pessoa: “não adianta dar um boi para o orixá se você não aparece para limpar seu santo, se deixa ele sujo, jogado, não está nem aí para ele. O orixá não aceita e não vai trabalhar para você”. Esse é um risco constante, o de "perder" um santo, mais do que desagradar ou contrariar uma divindade. Tal risco é ainda mais danoso em relação aos santos que se herda, já que as obrigações com estes são ainda maiores do que as daqueles que nascem com a pessoa, como veremos no final do capítulo. 
Por fim, cabe ainda ressaltar nesta introdução que algumas das divindades ocupam lugares no peji com base em suas características míticas. Existem assentamentos que indicam onde querem ser colocados por meio do jogo de búzios. Mas, em geral, a disposição dos assentamentos segue um "padrão" que remete à disposição dos orixás tal qual no Sítio de Pai Adão: o Exu deve ser colocado sempre na entrada do peji; outros orixás, como Ogum e Ode, devem residir no chão; Ossayin e Olofin estão sempre cobertos e "escondidos" no peji, onde ninguém possa vê-los. Divindades como Xangô, Iemanjá, Oxum, Ibeji e outros podem escolher onde querem ser colocados, embora alguns sejam frequentemente agrupados no mesmo local,

pois "comem" a mesma comida e são da mesma familia; outros, ainda, são separados espacialmente pelo motivo inverso, como Oya e Xangô, dada a evitação do carneiro por Oya e esse ser o principal alimento de Xangô; Orixalá, por outro lado, permanece separado dos demais orixás porque aqueles "comem azeite de dendê", substância estritamente proibida para o último. Após essa breve introdução, passo à descrição do peji.

\section{O PEJI}

Na geografia da "Casa de Tia Lu”, como o Ilê Iemanjá Ogunté também é chamado, o quarto da frente é habitado por Mãe Lú. Nos tempos em que Malaquias era vivo, esse era o seu quarto com sua esposa Leônidas. O quarto do meio, onde hoje dormem Bárbara e seus filhos, Thauany, Thalyson e Talita, antes era ocupado pela mãe de santo. O terceiro quarto é morada de Bino e Paulinho, sobrinhos de Mãe Lu e filhos de Pai Paulo. Quando estava em Recife, Pai Paulo dormia nesse quarto. Ali também já morou Tia Zeres, seu marido, Orlando, e seus filhos. Entre o quarto de Bino e Paulinho e os banheiros, há um corredor que liga a cozinha à sala, onde se encontra uma cama ocupada por Márcio, que, desde que se separou, voltou a morar na casa onde residia quando criança.

Após a cozinha, encontramos o barracão. Uma ampla sala, de aproximadamente 30 metros quadrados, coberta com telha brasilite. No centro está o ojubó, o centro do axé, um pequeno azuleijo quadrado no meio do barracão. Na extremidade oposta à cozinha, está o balé, quarto dos mortos, que ocupa um espaço contíguo à cozinha dos santos, a qual consiste basicamente em um espaço com um fogão à lenha disposto paralelamente em um pequeno corredor e à entrada do balé. Esse espaço é restrito aos homens, e as mulheres não devem se aproximar dele. Em Recife, os espaços dos eguns ou ancestrais devem ser separados dos orixás, 
ainda que coexistam em um mesmo terreno. No outro lado do salão, está o peji, ou quarto de santo.

Como disse na introdução, as casas de culto, em geral, possuem em seus domínios um quarto de santo correspondente à morada dos orixás (peji), um quarto para a Jurema (mesa de Jurema) e outro para os ancestrais (o balé). Por exemplo, nos dias em que se cultuam os orixás, não se deve adentrar no balé ou no quarto da jurema. É preciso esperar todo o tempo ritual das obrigações - oferendas de comidas e animais, seus preparos e o tempo de repouso nos assentamentos, até serem despachados no mato ou nos rios - para que outro domínio ritual seja acessado.

Outra característica importante em relação aos terreiros do Recife é o fato de as casas de santo serem inseparáveis da moradia familiar dos chefes de culto. À exceção de poucos casos, quase sempre o núcleo familiar consanguíneo de seus líderes divide com os santos sua habitação. Os terreiros se organizam em pequenos lotes: usa-se sempre todo o espaço do terreno para construções; se o terreno é pequeno e as condições materiais possibilitam, um andar superior é construído para ser utilizado como moradia da família. Frequentemente esses lares são chefiados por mulheres. Se a execução ritual em obrigações muitas vezes se dá em relação a um pai de santo, os lares têm sua rotina, despesas e decisões importantes a cargo de uma mulher.

Existe sempre uma tensão em administrar essas dimensões, quais sejam "a parte do culto" e "a parte familiar". Alguns filhos de santo se queixam da ingerência dos "assuntos de família" nas "coisas do culto", ainda que também possam existir queixas no sentido contrário, em especial no que se refere à não contribuição nas contas da casa pelos filhos de santo. $\mathrm{O}$ esforço em manter as dimensões separadas é constante por parte dos residentes em um terreiro. Por exemplo, conflitos podem também emergir da necessidade de ampliação de uma casa, pois o centro do axé que fica no barracão não deve ter, a rigor, uma construção de moradia por cima; vez ou outra, no entanto, cômodos são construídos ou expandidos para acomodarem parentes, um ou outro filho de santo e agregados. Ou uma questão entre irmãos pode se desdobrar em um conflito familiar que dificulte a rotina do terreiro, e assim por diante.

Nos terreiros de Recife, a proximidade com os santos na convivência diária não pode ser meramente atribuída a uma disposição espacial reduzida pelos limites de um terreno, nem mesmo às condições comuns de moradia das ditas classes médias baixas brasileiras. Mesmo em terreiros que ocupam uma grande área (cada vez mais raros, é verdade), o espaço de residência da família e os quartos de santo são conjugados em condições similares às descritas para 
pequenos terreiros. Parece-me que, para os praticantes do candomblé nessa cidade, a proximidade com os orixás não é apenas uma imposição de pouco recurso material das casas, mas um desejo de viver próximo aos santos.

\section{Exu}

O primeiro ato que se faz ao entrar em um terreiro nagô é saudar os santos no peji. Assim, é comum que alguém adentre a casa sem tocar campainha alguma, ou sequer anunciar sua presença e cumprimentar os presentes. Antes de falar com alguém, deve-se caminhar até a porta do quarto dos santos, fazer um movimento circular com as mãos sincronizado com os pés saudando Exu, para em seguida colocar as mãos no chão e levar à cabeça saudando os Santos. Diversas vezes assisti Junior Boto ou Bino advertindo alguém que lhe pedia benção sem antes passar no peji. Quando isso acontecia, Pai Paulo costumava alegar: "Eu não sou Exu para você pedir a benção primeiro". Somente depois da saudação inicial, a pessoa poderia, enfim, cumprimentar os presentes na casa.

Na maioria das vezes, a saudação é feita com a porta do quarto fechada. No nagô, em particular, mas também no candomblé, em geral, existem algumas restrições em relação ao acesso de pessoas ao quarto de santo. Uma das principais regras é aquela que determina que não se deve adentrar esses espaços de "corpo sujo", ou seja, tendo tido relações sexuais na noite anterior. Nesse estado de "corpo sujo", a pessoa deve evitar não apenas entrar nos quartos de santo, mas também ter qualquer contato físico com os objetos e coisas relacionadas aos santos. "Não pode pôr a mão em nada", diz Bino, já que nessa condição não se pode ajudar nas obrigações, cozinhar para os Santos, tocar os ilus ou mesmo receber o santo. Outra restrição relacionada ao corpo sujo é quando uma mulher está menstruada, devendo evitar o contato ou proximidade excessiva com qualquer objeto ou mesmo espaço do santo - o que não implica necessariamente na interdição da pessoa em todo o ritual, mas sim em uma distância segura para que ela o faça.

Os pejis sempre têm um ou mais exus assentados em sua entrada, à esquerda de quem entra, no limiar da entrada do peji. São os exus da casa, podendo ser ligados aos orixás regentes do pai ou mãe de santo, dono da casa, em geral do fundador ou da fundadora. Quase sempre, um ou dois assentamentos de exu são encontrados nos pejis. Nesses assentamentos, são feitas as oferendas para exu em cada obrigação. Junior Boto explica que "Exu é o mensageiro, ele quem leva as obrigações dos orixás para Deus". É o primeiro a ser saudado e sempre o primeiro que come. Se no nagô cada pessoa idealmente tem seu orixá em seu próprio assentamento, os 
exus são assentamentos mais coletivos, utilizados por todas as pessoas da casa. Marcio me disse certa vez que o "certo" era ter um Exu para cada filho de santo, mas que não havia disponibilidade espacial para isso nas casas. Outras pessoas defendem que na tradição há um ou dois exus por cada casa. Há ainda aqueles que defendem que a quantidade de exus tem a ver com os santos de cada casa, pois cada orixá tem o Exu de sua preferência, aquele que deve servir como seu escravo. Embora se tenha um número reduzido de assentamentos de exu, podese invocar uma quantidade enorme destes para vir comer no assentamento específico, desde que invocado e nomeado corretamente.

Os orixás, como ensina Malaquias a José Jorge de Carvalho, não existem no abstrato, pois são coisas vivas. Os assentamentos, nesse sentido, servem como a presentificação de uma relação, a materialidade de um vínculo entre a pessoa e a divindade. Tal como notaram Carvalho (1984), Segato (1984) e Halloy (2005), os assentamentos são sempre referenciados em relação à díade pessoa-orixá.

Além dos exus do peji, há ainda um assentamento de exu fora do barracão ou na parte da frente das casas, chamado exu do portão ou exu da rua. No Ilê Iemanjá Ogunté, esse exu fica ao lado da casa dos exus de Jurema, ainda que cada um ocupe seu lugar e possua construção específica.

Os exus do peji são assentados em pedras, preferencialmente em pedras de laterita, grandes pedras ricas em minério de ferro, de cor vermelha e bastante porosas, comumente enegrecidas pelos sacrifícios. Digo preferencialmente porque outras "qualidades" de pedras são aceitas para Exu. Essas pedras são depositadas em um alguidar de barro.

Os principais exus do Ilê são Akessan (um exu recebido como herança de Tia Inocência, irmã de Leônidas), Osa (Exu de Iemanjá de Malaquias) e Yangui de Pai Paulo.

De todo modo, o principal componente de um assentamento é o otá. Em geral, essas pedras devem ser encontradas pelos próprios filhos de santo (Carvalho, 1984 Segato, 1984; Marques, 2016; Rabelo, 2014; Sansi, 2009, et all). Há várias narrativas desses “encontros” ou reconhecimento por parte da pessoa e suas pedras. Pai Paulo sempre narrava como encontrou a pedra do Exu Yangui aos sete anos, após uma grande enchente, e como ela teria rolado até ele. Chegando em casa, pediu para seu pai jogar e confirmar se aquela era mesmo um Exu. Esse processo de encontro e confirmação faz parte do processo de individuação de uma pedra em um otá.

Mas nem sempre esses encontros são positivos. Mãe Lu recorda que, certa vez, seu exmarido encontrou uma grande pedra preta, muito bonita, numa casa que estava à venda em um 
bairro da redondeza e levou a pedra para casa. Ele passou a sofrer uma série de infortúnios com o passar dos dias, até que Pai Paulo jogou os búzios e confirmou que aquela pedra era um exu , o qual não queria ficar no terreiro e por isso deveria voltar para o lugar exato em que foi encontrado, pois pertencia àquela casa de onde foi retirado. São incontáveis as narrativas análogas, sobre pessoas que encontraram pedras e as levaram para si, acarretando uma série de situações e problemas até que o jogo revelasse que eram santos ou exus que foram despachados e gostariam de permanecer onde estavam.

De todo modo, quando esse encontro é positivo, de acordo com a confirmação do jogo de búzios, e a pedra encontrada é de fato um otá para a pessoa que a encontrou, ela deve ser lavada com o sumo de ervas do amassi e tornar-se um assentamento específico de um santo ou ser incorporada a algum assentamento já existente.

O assentamento de Exu possui ainda uma outra peculiaridade: o seu otá sempre lembra a forma de uma cabeça humana. Pode-se ainda estampar a pedra com búzios, conferindo-lhe essa característica de um rosto humano com olhos, boca e orelhas. Como bem notou Arnaud Halloy (2005, p. 519), “pedra de Exu, assim, seria a única pedra que precisa ser transformada, no sentido físico do termo, para se tornar um objeto de culto completo e desempenhar uma função dentro do culto".

Uma antiga mãe de santo de Recife, ligada ao Sítio de Pai Adão, explicou essa transformação do otá de Exu a José Jorge de Carvalho:

\footnotetext{
"Exu era um orixá e encantou-se no dia 24 de agosto, ao meio-dia e somente quem descobriu isso foi Orunmila. No dia 24 de agosto Orunmila consultou o opele (oráculo) convocou todos os santos e disse: 'do meio dia de hoje em diante, nenhum de vocês deve sair de casa. Não é bom para ninguém sair depois do meio-dia'. Todos o ouviram. Mas Exu, sempre rebelde, um orixá que nunca gostou de obedecer a ninguém, nem mesmo a seu pai e sua mãe, quando foi tarde ele saiu e foi para estrada. Sempre que ele chegava no meio de uma encruzilhada, ele se materializava, tornavase um vulto. E é por isso que podemos materializar um vulto de Exu; você pode pegar uma pedra, tirar um vulto dela e fazer o Exu que você quiser [...]" (Carvalho, 1984, p. $70)$.
}

Enquanto os Exus geralmente são pedras que precisam ser transformadas, "feitas como um iaô", como explicou Pai Guará para Halloy (2005, p. 519), os demais orixás são entendidos como forças divinas, tendo sua materialização em algum aspecto da natureza, da qual são tanto parte como expressão (o rio é tanto parte de Oxum como é Oxum; o mar é parte e é Iemanjá, etc.). Os otás, nesse sentido, são a materialização por excelência dessas forças, servindo tanto como domicílio quanto como o próprio santo. 
Essa materialização do orixá na forma do otá foi vista por José Carlos dos Anjos (2006) como uma singularização de diferentes intensidades que compõem o mundo afro-brasileiro. Em uma bela formulação, ele nos diz que "a religiosidade afro-brasileira insiste, num primeiro momento, em não artificializar a forma do que é demasiadamente grandioso para mãos humanas" (2006, p. 76). Para o autor, o acuta (outro nome para o otá) explicita uma relação entre o material concreto e a divindade, em uma relação de "imanência e não transcendência". Vale a pena pensar por um momento. Tais singularizações dessas intensidades ocorrem em momentos precisos, um encontro entre uma linearidade mitológica (as passagens dos orixás, novos, velhos, crianças, guerreiros, sedutores) e a concretude material que o incorpora, um corpo humano, uma pedra, uma imagem. Cada passagem seria uma singularização, uma individuação, "um mesmo nome 'xangô', percorrendo diversas passagens, singularizando-se numa multiplicidade de momentos" (idem).

De todo modo, assim como os orixás, as pedras têm de estar vivas para que possam ser otás, ou seja, devem ter a capacidade de manter a força das oferendas em si enquanto receptáculo delas, propiciando seu próprio crescimento. Isso não é uma mera alegoria: em Recife, as pessoas atestam que seus otás podem crescer ou diminuir de tamanho, conforme recebem ou deixam de receber obrigações. Um dos exemplos é narrado por um dos exus da própria mãe de santo Isaura (Exu Elegbara)que, após sua morte, tendo deixado de receber as obrigações, seu tamanho foi diminuindo e hoje não é mais do que uma pálida lembrança de seu esplendor nos áureos tempos.

Exu é aquele que pode ser "representado" enquanto uma forma humana em seu próprio assentamento. Um ser moldado em massa de barro ou em pedra, que tenha uma feição humana, com olhos, boca e orelhas geralmente marcados com búzios. É importante ressaltar que tal forma é necessariamente uma imagem, no sentido forte da expressão: não busca uma representação, mas uma lembrança, um vulto. Essa possibilidade é acentuada nos exus de Jurema, que são feitos como bonecos de barro com formas humanóides ou ainda enquanto imagens de gesso, sempre referidas também como vultos. É o único caso em que as próprias imagens são consideradas enquanto aspecto do próprio santo e não meramente uma representação, uma imagem alegórica como no caso das imagens de santos católicos no peji.

Outra singularidade própria de exu é a possibilidade de ele ser "visto", dada sua condição de vulto. Exu, como já demonstrado na literatura antropológica ${ }^{82}$, é um orixá que possui um aspecto singular em relação aos demais, singularidade essa descrita muitas vezes

${ }^{82}$ cf., entre outros, Vagner Gonçalves da Silva (2020). 
como a de um trickster, um orixá das fronteiras, limiares e movimentos. Há, no entanto, uma diferença importante entre exus batizados e exus pagãos ou da rua. Os exus batizados são aqueles que ficam próximos aos orixás, habitando o peji e os espaços do terreiro. Já os pagãos são aqueles que habitam as ruas, encruzilhadas e os fundos das casas (retornarei a esse ponto mais à frente). Em Recife, seu aspecto múltiplo é ressaltado como o único orixá a ser cultuado em todos os domínios cosmológicos dos terreiros (peji, eguns e jurema), ainda que em cada domínio seu assentamento se altere de acordo com os preceitos e singularidades de cada um deles.

\section{Iemanjá}

No terreiro Ilê Iemanjá Ogunté, como o próprio nome indica, Iemanjá possui o principal assentamento. Foi com ele que se fundou o terreiro. Pai Paulo contava frequentemente que seu pai Malaquias sempre levava seus santos com ele nas casas em que morou. No começo, Iemanjá ficava dentro de um armário, guardada, e ele a levava até o Sítio para as obrigações e trazia de volta para casa. Ele lembra que Iemanjá sempre relutava, queria ficar no Sítio. Foi após a morte de José Romão e os eventos que se sucederam - que culminaram com a saída da família de Malaquias do Sítio -, o terreiro começou a ganhar a forma como se encontra hoje.

Alguns orixás já estavam na casa, e por isso construíram um pequeno quarto. Aos santos de Malaquias e Dona Leônidas, foram acrescentados a Iemanjá de Mãe Lu e as Oxuns de Guara e de Tia Zite. Aos poucos, outros orixás foram sendo assentados e ocupando seus lugares na topologia do quarto. À medida que o terreiro foi crescendo e as novas gerações assentando seus santos, o peji foi aumentando. Nos últimos anos, prateleiras foram erguidas. Hoje, nos dias de grandes obrigações, praticamente todo o ritual é feito no salão, à exceção de Exu, Ogum e Ossaim, que são feitos dentro quarto.

$\mathrm{Na}$ maior parte do tempo em que estive em campo, o assentamento de Iemanjá esteve no chão, "trabalhando". Após a morte de Pai Paulo, Iemanjá relutava em subir para seu lugar na prateleira. Nas sextas-feiras, após o arroz de Orixalá, Mãe Lu jogava os búzios e o odu que repetidamente caía era osatinuko, um odu em que fala Iemanjá. Ela sempre respondia negativamente quando instada a subir. Até que um dia Mãe Lu se lembrou de que, quando seu pai faleceu, Iemanjá também se negou a subir sem antes receber um carneiro: “Quando meu pai morreu, ela também não quis subir, ela ficou triste em perder um grande adorador, ela está de luto por Linho (Pai Paulo)". 
O assentamento de Iemanjá encontra-se ao lado de Orunmila e Oxum. Da porta, é o primeiro orixá que se enxerga quando se olha para o peji e é sempre reverenciado batendo-se cabeça. Os assentamentos de Iemanjá são imponentes, com muitos otás, colares e pratos. Suas cores são gradações entre o azul-escuro, o azul-claro e o verde água.

Como mencionei, no assentamento de Iemanjá da casa, fundiram-se os dois principais assentamentos de Iemanjá da família: os de Malaquias e de Mãe Lu. Antigamente eram dois assentamentos distintos, mas Pai Paulo os uniu em um só, o igbá de Mãe Lu: uma grande terrina branca com fundo azul claro, com uma sereia impressa como marca d'água, guarda-se uma grande quantidade de diferentes otás. O otá de Malaquias é um pequeno seixo de rio, bem escuro, do tamanho de uma moeda. Em uma das muitas limpezas dos santos de que participei, Junior Boto me chamou e disse: “Olavo, está vendo essa pedrinha? Ela é o alicerce de toda a nossa família”. Sobre essas pedras, alguns fios de contas em tons de azul escuro, além de moedas e búzios, finalizam o conjunto.

Mae Lu conta que, quando seu pai faleceu, Tia Vicência e outras pessoas queriam despachar Iemanjá, mas esta se recusou afirmando que queria ficar a fim de continuar cuidando da família, permanecendo "junto da gente, nas dificuldades e alegrias", prossegue Mãe Lu:

"Iemanjá acompanhou a gente em muita coisa, ela sempre ajudou, mas, às vezes, dava cada surra, cobrava mesmo. Passamos muitas dificuldades: meu pai ia trabalhar a pé daqui até o prédio da Receita Federal na cidade. Faltava dinheiro. Um dia ele ganhou um carneiro bonito para Iemanjá, grande, demos o nome Mimoso. Aí meu pai, em um momento de extrema necessidade, vendeu o bicho. Pra quê?... Aí que foi pau mesmo: dormíamos todos os filhos na mesma cama, minha mãe fez um colchão com umas roupas, era cobrança de Iemanjá por ter vendido o carneiro dela. Aí meu pai conseguiu um carneiro e deu a ela, ele entrou no Sitio de joelhos, pedindo perdão... Ela chorou muito quando ele foi embora [refere-se ao pai]. Mas ela não quis ir embora, quis ficar com a família dela. Eu sempre invoco o egun de Tia Inês, de meu avô Adão, de meu pai quando estou pedindo a presença de Iemanjá, para que eles venham interceder por mim, pelos meus filhos e que completem aquilo que eu não sei fazer. É assim com todos os orixás, que esses filhos venham ajudar a gente, eles são mais próximos das divindades, podem interceder por nós...”

A grande obrigação para a entidade é o "presente para Iemanjá", que ocorre no final de dezembro ou início de janeiro. O presente é preparado com uma cabeça de boi e o fato. Estes 
são tratados com o mesmo rigor ritual de uma obrigação envolvendo animais de quatro pés. Após três dias, há o sacrifício de um carneiro para confirmar a obrigação.

\section{Oxum}

A Oxum da casa é o antigo assentamento da Oxum de Dona Leônidas, Omiseun. Nele estão os otás das Oxuns da família de sangue, ao menos daqueles que têm Oxum como segundo ou terceiro santo. A casa, segundo Boto, é de Iemanjá e Oxum: "Ninguém nasce da guimba do pai, todo mundo tem mãe, a nossa avó era fundadora dessa casa tanto quanto meu avô, Oxum Ijimu e Iemanjá Ogunté", disse ele. O assentamento de Oxum constitui-se de uma sopeira de porcelana amarela, com uma grande quantidade de otás que acompanham o principal de Oxum. José Jorge de Carvalho, ao analisar o assentamento de Oxum do Sítio, descreve a presença de vários otás "para fazer companhia ao otá principal" (Carvalho, 1984, p.126). Alguns assentamentos caracterizam-se pela presença de outros otás além daquele do Orixá da pessoa, como é o caso do Orixalá de Idelfonso, que, segundo ele, quis mais alguns para não ficar sozinho.

A disposição desses otás segue uma hierarquia de acordo com a importância de cada um. No centro do igba, sempre fica o principal, aquele que foi consagrado no momento da lavagem da cabeça por ocasião da feitura da pessoa; ou, caso seja um assentamento herdado, o otá do centro será o orixá da pessoa a quem pertencia o igba. Próximo a este, ficam os demais, cada qual ocupando uma determinada localização. Sempre que são feitas as limpezas nos assentamentos, uma pessoa mais velha confere se ele foi remontado, obedecendo a posição original de cada coisa em seu interior. Junto ao assentamento, além dos pratos que o acompanham, são colocados ainda Abebes $^{83}$, Ades $^{84}$ e outros objetos referentes aos adereços dos orixás quando são vestidos em suas festas. Outra singularidade em relação aos objetos que acompanham o assentamento de Oxum é a presença de uma faca exclusiva desse santo, ainda que nem sempre utilizada durante as obrigações. Arnaud Halloy traz algumas elaborações interessantes sobre isso, que transcrevo na íntegra:

A segunda exceção é Oxum que, de acordo com as palavras usadas, "Oxum tem sua própria faca”. Isto é o que Zite diz: 'Oxum não espera por ninguém ... É por isso que ela tem uma faca a seus pés ... Ela é a única que é assim, um pouco rebelde ... Ela não vai esperar por Ogum...'.Encontramos de fato uma faca no assentamento deste orixá. Para justificar essa peculiaridade, vários líderes de cultos me mandaram de volta ao

\footnotetext{
${ }^{83}$ Espelho de metal em forma de abano.

${ }^{84}$ Tiara de metal em forma de coroa.
} 
início do seu repertório, que também pode ser cantado durante a sua obrigação em vez de "Ogum xôxô":

Iyá omi nlo momo

Aládé o olú omi o

Òsun òsòrò k'á má má mà sè o

Èwùjì f'ìbà ogún y'aba omi

Eyin ògbèrì e dòrí kodó...

O que parece particularmente interessante para mim neste exemplo é que a tradução da toada em questão vem justificar o fato de Oxum poder fazer seu sacrifício sem Ogum, uma vez que tem sua própria "faca" (Halloy, 2005, p. 514).

\section{Ibeji}

Dois pequenos alguidares de barro estão sempre próximos à Oxum da casa. São os assentamentos do orixá Ibeji, tidos como filhos de Oxum. Cada alguidar possui um pequeno colar multicolorido, além de bolas de gude e doces de criança, que são sempre depositados em seu interior. Esses alguidares não possuem nenhum emblema, estão descobertos. Durante sua festa, próxima ao dia das crianças em outubro, os Ibejis comem frangos.

A festa de Ibejis ocorre no domingo mais próximo do dia 12 de outubro. Todos os filhos da casa se organizam para comprar uma grande quantidade de doces e brinquedos, que são distribuídos para a comunidade do entorno do terreiro. Um pequeno xirê é realizado e, em seguida, as sacolas de doces e brinquedos que estavam aos pés dos assentamentos são distribuídas. O ponto alto da festa é a "quebra do pote", uma grande panela de barro recheada de balas e enfeitada com papel crepom multicolorido. Essa panela é colocada em frente a casa, pendurada em uma corda que é atada de uma ponta a outra da rua. Uma grande quantidade de crianças aglomera-se para tentar quebrar o pote com um pedaço de pau. A criança da vez é vendada e rodada algumas vezes sobre seu próprio eixo. Assim, com grande alarido, ela tenta quebrar o pote, o que gera uma cena bem divertida e que alegra todos os presentes.

No nagô, não há incorporação das entidades conhecidas como erês (espíritos infantis). Nos últimos anos, no entanto, alguns filhos de santo iniciados em outras casas de nações jeje, recebem seus ires $^{85}$ que são rapidamente "despachados".

\footnotetext{
${ }^{85}$ Conhecidos como “eres" nas nações ketu e angola.
} 


\section{Orunmila}

No centro das prateleiras de cimento, habitam os principais santos do nagô. Entre Oxum e Iemanjá, nas casas que o possuem, fica o assentamento de Orunmila, tido por muitos como o orixá mais importante da nação ou o "santo da nação" por excelência.

Fixado na parte superior da prateleira onde reside Oxum, o assentamento de Orunmila consiste em uma terrina de louça com ikins (Elaeis guineenseis, caroço de dendê de quatro olhos) e outros objetos, além de um fio de contas em verde e amarelo. Sua terrina está sempre coberta com um pano das mesmas cores. As principais casas do nagô possuem um assentamento desse orixá. Todas as oferendas para Orunmila devem ser feitas em par. Essa predileção pelo duplo aparece nos signos dessa divindade nos alimentos e na companhia dos orixás que comem com ele em suas obrigações (Oxum e Iemanjá). Idelfonso conta que, em sua casa, sua mãe nunca permitiu que se bebesse em xícaras sem pires, ou que a mesa fosse posta em números ímpares, "tudo de Orunmila é de dois, sempre em par", explicava ele.

No Sítio, encontra-se o assentamento do Orunmila de Tia Inês: Ogbe Irete. Algumas pessoas consideram que ela própria era filha de Orunmila. Pai Paulo sempre dizia que, quando uma mulher é filha de Orunmila, coloca-se Iemanjá como santo de frente, pois mulheres não poderiam ter Orunmila como primeiro santo. Segundo ele, quando o assentamento é de uma mulher usam-se cinco ikins, enquanto para os homens são utilizados dezesseis ikins.

Também havia no Sítio um segundo assentamento, que era do Orunmila de Pai Adão: Okaran Irete. Esse assentamento, segundo contam na família, não se encontra mais ali. Durante o período de perseguição aos terreiros, logo após o falecimento de Pai Adão, os orixás foram para a casa de seu filho, Mundinho, no terreno ao lado do Sítio. Houve então uma batida policial em que sequestraram, além do assentamento de Orunmila, o Xangô de Pai Adão. Pai Paulo afirmava que esse Orunmila estava no acervo do Museu do Estado. Na época, confesso que não dei tanta atenção a essa possibilidade, uma vez que julgava que poderia ser uma referência imprecisa aos objetos roubados pela polícia naquele período e doados à missão de Mário de Andrade nos anos 30. Contudo, após a morte de Pai Paulo, uma colega que estava pesquisando o acervo do Museu do Estado encontrou um conjunto de objetos que são característicos de um assentamento de Orunmila. Dada a especificidade dos objetos e o número reduzido de assentamentos existentes dessa entidade, considero que Pai Paulo continua a me dar lições importantes, confirmando aquilo que eu julgava inexato.

$\mathrm{Na}$ época em que José Jorge de Carvalho realizou sua pesquisa, havia não mais do que cinco assentamentos desse orixá em Recife. Um se encontrava na casa de Maria das Dores, 
chamado por Ijogbe. Ele era de uma antiga mãe de santo de Recife, que teve seu quarto de santo demolido após sua morte. Assim, José Romão decidiu entregar esse assentamento aos cuidados de Maria das Dores. Segundo o que foi informado na época para o pesquisador, esse Orunmila era um santo jovem e seu fundamento era incompatível com os que havia no Sítio, não podendo, portanto, ser abrigado lá (Carvalho, 1984, p. 81). Esse Orunmila ainda é cultuado na casa de mãe das Dores, tendo Bino oficiado a última obrigação dedicada a ele em 2017. Além desse assentamento, Carvalho conta que haveria um outro na antiga casa de Mãe Lídia, uma importante mãe de santo do início do século passado, avó consanguínea de Manuel Papai, o atual dirigente do Sítio, e filha de santo de Artur Rosendo da nação Xambá, que, com a morte deste, passou a realizar suas obrigações com José Romão. Esse Orunmila chamava-se Oto Birikusa e seria de uma antiga casa, tendo sido herdado em condições similares ao anterior. E, por fim, era conhecido o Orunmilá do antigo pai de santo e babalaô Claudino Bamboxe. Contemporâneo de Pai Adão, segundo Pai Paulo, era da nação jeje e tinha um importante terreiro no Recife. Contemporâneo Pai Paulo o apresentava como o outro africano que jogava Ifá: "Claudino Gomes de Almeida, Bamboxê, era da nação jeje, jeje-mahi, Pai De Eustáquio e avô de Jeronimo. Eles [Claudino e Adão] eram muito próximos, costumavam se visitar e comparar o resultado do jogo. Um confirmava o que o outro falava". Pai Paulo conta ainda:

“Claudino tinha um livro sobre Ifá, que veio da África já naqueles tempos. Sempre que eles entravam em desacordo sobre um recado do jogo, ele ia confirmar no livro se meu avô estava certo. [...]Uma vez,meu avô avisou Claudino para não ir trabalhar: 'Claudino, Ifá falou que você deve ficar em casa hoje'; e Claudino disse 'que nada, Adão'; e foi trabalhar. Ele matava bois, aí quando ele foi cortar o boi, a faca entrou na sua coxa, e na hora ele lembrou que meu avô havia alertado. Ele foi para casa, mas antes comprou duas caixas de cerveja e parou na porta de casa com elas. Cada pessoa que passava ele abria a garrafa e oferecia para pessoa: 'aceite essa cerveja, foi Ifá que lhe deu'. Ele fez isso para pagar promessa."

Paulo costumava dizer que seu avô era muito bom no jogo, que ele ficava sentado na varanda do Sítio observando o que se passava.

"Todo dia de manhã ele fazia como eu faço: jogava pra mostrar o recado do dia. Um dia veio um sujeito passando pelo Sítio e falou assim 'bom dia Adão'. 'Bom dia nada, volte para sua casa e peça desculpa a sua esposa, ela está certa e você errado'. O homem voltou na mesma hora, sem jeito. Meu avô era muito bom no jogo. Ele sempre confirmava o que o jogo dizia." 
Uma das especificidades encontradas nos candomblés em Recife é a presença de um culto específico dedicado a Orunmilá nos terreiros nagôs, em especial os terreiros descendentes do Sítio de Pai Adão. Esses terreiros dispõem de um complexo ritual inteiramente dedicado a essa divindade, com um conjunto exclusivo de cantigas rituais em iorubá para Ifá e Orunmilá.

Outra especificidade do culto a Orumilá é a presença de uma atividade ritual específica destinada às mulheres: a função de Apetebi da obrigação. O nome Apetebi refere-se a "esposa do babalawo"; na Nigéria, uma das esposas do babalawo é responsável por cuidar dos objetos da divindade, não sendo necessariamente uma “iniciada” em Ifá. Já em Cuba, são as mulheres iniciadas que preparam as comidas servidas na obrigação de Ifá. Em Recife, o termo não designa um cargo religioso ou esposa do babalawo, como acontece nesses dois lugares. Tratase de uma posição ritual, ocupada por uma filha de Oxum ou de Iemanjá, que experimenta a comida de Orunmilá durante a segunda parte da obrigação e cumpre determinados atos rituais na primeira - aqui ressurge meu compromisso com Pai Paulo em não tornar públicas certas dimensões dessa prática.

Esposas na Nigéria, iniciadas em Cuba, experimentadoras em Recife, os arranjos e acordos envolvendo as Apetebis não são os mesmos; como eu disse, transformações ocorreram, mas a "aliança" se mantém. Pai Paulo dizia que Oxum foi esposa de Orumilá, e por isso eles sempre "comem" juntos. Não obstante, se uma mulher for filha de Orumilá, ela seria feita como filha de Iemanjá. Pai Paulo conta o caso de uma prima sua:

“A filha de meu tio Zé Romão era de Ifá, mas cultuava Iemanjá. O nome 'africano' de Tia Vicência era "Ifadairo", ela era filha de Iemanjá, mas tinha Ifá no nome, Tia Inês a mesma coisa, não era 'Ifátinuké' Só que o Ifá dela por ser mulher só vai um Ikin, e o povo acha que todo Orumilá é assim ..."

Na aliança Oxum, na filiação Iemanjá. As Apetebis comem a comida que é ofertada para Orumilá. A relação expressa pelo "comer" reforça essa ligação: "Eu como com você e você come por mim".

Das obrigações de Orumilá que presenciei, houve sempre uma variação das mulheres que ocupam essa posição ritual. Na casa de dona Zetinha, eram Tia Zite e uma filha de santo de dona Zetinha. Já no terreiro de Dão, quem forma as Apetebis são as duas filhas de santo de Oxum. Mãe Lú me contou que ela era Apetebi das obrigações de Orumilá em sua casa. Na etnografia de José Jorge de Carvalho, figuravam como Apetebis Tia Vicência e Amara.

Pai Paulo diz que é possível, ainda, que, na falta dessas iniciadas, uma filha de outros orixás venha a desempenhar essa função no momento da "obrigação": 
"Pode ser até mesmo uma mulher menstruada, não foi assim que aconteceu?. Foi uma mulher menstruada que salvou ele, eles estavam perseguindo Orumilá, porque ele tirou a virgindade da filha do rei, aí o rei mandou matar ele, e ele fugiu e foi correndo, correndo, correndo, ai ele viu uma mulher bem alta, né, com a saia até em baixo, e ele foi e entrou por baixo da mulher, ele era pequeno, né, baixinho. Aí ele ficou em pé embaixo da saia, mas a mulher estava menstruada, por isso não tem problema da mulher menstruada na obrigação dele, não foi a mulher menstruada que salvou ele? Então..."

Nos terreiros nagôs de Recife, nota-se que Orumilá ou Ifá possui um estatuto especial considerado "superior" aos outros orixás. Arnaud Halloy, ao comparar seus estudos com os resultados obtidos, no final dos anos setenta do século passado, por José Jorge de Carvalho, percebe uma mudança nas atribuições de Orumilá e Ifá. Carvalho (1984, p. 138) observa que Orunmilá e Ifá "não eram diretamente equivalentes", pois a palavra Ifá seria utilizada na expressão "consultar Ifá" - que significaria "consultar o oráculo"-, enquanto que Orumilá seria uma divindade e teria uma "presença mais concreta", enquanto divindade, entre os membros da comunidade. Suas obrigações ocorreriam a cada cinco ou seis anos (Idem, p.140).

Contudo, como afirmou Halloy, atualmente Ifá é descrito em Recife como um orixá diretamente relacionado com um jogo/oráculo específico, por meio do qual responderia com mais efetividade. Apesar de ainda estar relacionado ao jogo de búzios, o jogo de Ifá propriamente dito consistiria no uso da técnica operatória dos ikins (caroços de dendê) e seus vereditos seriam considerados mais "completos" pelos praticantes. (Halloy, 2005, p.169).

Ademais, a obrigação para Orumilá tornou-se mais recorrente. Durante os meses de dezembro de 2013 a agosto de 2014, pude presenciar duas obrigações para Orumilá e, entre janeiro de 2015 ao final de 2018, mais quatro obrigações para esse orixá em terreiros distintos. A maior frequência parece refletir a extensão das inovações realizadas por Pai Paulo na "atualização" do culto da divindade. Assim, com a recente introdução no culto dessa nova técnica do jogo de Ifá com ikins e opelê, o culto da divindade que rege o oráculo Orunmilá parece ter ganhado maior importância e suas obrigações passaram a ser anuais.

No final dos anos setenta, como Carvalho (1984, p.140-141) também mencionou, encontravam-se em Recife apenas cinco dos pequenos assentamentos "autênticos" desse orixá, "preparados pelos líderes ainda vivos que sabiam como fazê-lo". No decurso de minha pesquisa, pude contabilizar, ao menos, dezessete assentamentos dessa divindade, todos feitos por Paulo Braz. Essa informação nos permite visualizar uma significativa mudança nesse 
contexto, sem ignorar o que Halloy (2005, p.169) presumira em sua pesquisa: "Ora, parece que, hoje, a complexidade do culto deste orixá e responsabilidades rituais que ele implica que agem um pouco como um freio a uma maior expansão".

Um dos efeitos dessa intensificação ritual do culto a Orunmilá foi a recuperação de técnicas oráculares e rituais de Ifá. Tais recuperações se estendem a outros projetos, como a introdução de novos cânticos, a intensificação de rituais antigos, entre outros elementos e práticas.

\section{Oba e Ewa}

Ao lado da primeira prateleira vertical do peji, guarda-se uma profusão de pequenas sopeiras de porcelana e pratos: são os assentamentos dos orixás das águas, Oxum, Ewa e Oba, sendo que Oxum ganha proeminência nessa prateleira devido à quantidade de assentamentos e à importância desse orixá em Recife. A composição desses dois assentamentos é similar aos dos orixás femininos: uma terrina de cerâmica tampada com um dos pratos do conjunto que os acompanha. No interior, além do otá, há várias moedas e o fio de contas depositado em rodilha sobre a pedra.

Segundo contam, houve apenas uma filha de santo de Oba no nagô: Tia Maria Anunciada, mãe de Tomé e esposa de Mundinho (filho primogênito de Pai Adão). De acordo com Halloy (2005, p.507), o assentamento desse orixá seria uma "novidade", na medida em que apareceu com a atual geração de líderes de culto. Segundo Carvalho:

\footnotetext{
Obá é outro orixá a respeito do qual as pessoas sabem muito pouco. Há quarenta anos atrás houve uma mulher no Sítio que era filha de Obá e ficava possuída por ela; e ela é a única pessoa de quem eles se lembram. Muitos dizem que Obá é uma das três esposas de Ifá, juntamente com Oxum e Iansã. Eles conhecem seu estilo de dançar, o repertório de cânticos para ela e nada mais. Numas poucas casas-templos é associada à Nossa Senhora dos Prazeres, mas não sei em que termos se faz a ligação. Malaquias contou-me o seguinte a respeito dela: “Obá é uma santa guerreira. Ela é Nossa Senhora dos Prazeres. Obá lutou na guerra e eles cortaram um dos lobos de suas orelhas. Você deve dançar para ela colocando sua mão sobre o lobo que falta. Ela é muito furiosa porque perdeu uma orelha na guerra" (Carvalho, 1984, p.124).
}

Os repertórios de cânticos, invocações e estilo da dança do orixá constituem um importante meio pelo qual pode vir a ressurgir um assentamento ou filha de santo. Na época da etnografia de José Jorge de Carvalho e Rita Segato, não havia, por exemplo, assentamentos de Ewa e Exumare no Sítio de Pai Adão. Foi a partir da ampliação do repertório e das invocações, 
que Pai Paulo pôde assentar esses orixás no Ilê Iemanjá Ogunté. Ali não há assentamento de Exumare, embora haja em outros terreiros da família. Sobre isso, Bino explica: "a gente tem assentamento de Oba, Ewa e Ossaiyn, não temos de Exumare, mas poderíamos ter, tá entendendo? Porque temos invocações e toadas”. Um dos feitos de Pai Paulo foi ter incorporado novas toadas ao repertório do nagô. Tal feito é saudado como uma forma de evitar o desaparecimento do culto desses orixás- nos seus termos, da "adoração desses santos na família”.

\section{Ogum}

Passo agora ao conjunto dos orixás que, no nagô, ficam no solo. Iniciamos por Ogum. No Ilê Iemanjá Ogunté, o Ogum da casa é chamado Ogum já. Todos gostam de lembrar que aquele era o Ogum do Tio Zé Romão, (Ojo Okunrin). Além de pai de santo do Sítio, Zé Romão também foi pai de santo de inúmeras casas de suas filhas e filhos de santo, sendo as mais famosas a Casa de Maria das Dores e de Lídia Alves. Como já mencionei, ambas eram filhas de santo de Artur Rosendo, da nação Xambá, e após a morte deste, José Romão se tornou responsável pelas obrigações em suas casas, passando os rituais para o modo nagô. Além dessas casas, também oficiava as obrigações na antiga casa do Pátio do Terço. José Romão era filho de santo de Pedro Louvado e Joana Batista, antiga mãe de santo que liderou o Sítio após a morte de Pai Adão. Pai Paulo contava que desde pequeno seu tio já ajudava essa mãe de santo em suas obrigações, o que contrariava seu avô. Ele era seu Asipa e assumiu o Sítio após a morte dela. Não virava no santo, embora Pai Paulo dissesse que Ogum sempre encostava nele quando ele cantava pra este orixá. O modo como o tio cantava foi assunto de nossa última conversa, antes dele vir a falecer. Na ocasião, Pai Paulo me dizia que o tio sempre cantava dançando com uma toalha na mão, no meio do salão do Sítio. Chegava a engolir seco no meio da toada e se alegrava quando ele chegava fardado no Sítio, ainda mais se fosse no momento em que este cantava para Ogum. José Jorge de Carvalho traduziu assim essa cantiga:

\footnotetext{
Ohun gbogbo ni t'Ògún o t'ilé t'ònà ni t'àgbède Àrísí ni f'áwa ode

Ogún a kòró s'ohun gbogbo Kòró ire o

Ohun gbogbo ni t'Ògún — Tudo pertence a Ògún

ilé t'ònà ni t'àgbède — A casa e o caminho são de Àgbède

Àrísí ni f'áwa ode — Ele é uma inspiração para nós, caçadores

Ògún a kòró s'ohun gbogbo — Ògún é ligeiro ao fazer todas as coisas
} 
koro ire o - Expressão do dialeto de Ekiti: alguém encontra a boa sorte.

Malaquias Costa explicou-me do seguinte modo o significado dessa canção: “Todo mundo precisa de Ogún, até a costureira com a agulha, que também é de ferro; a cozinheira, no fogão; a lavadeira precisa do ferro para engomar; até o navio, que anda pelo mar. Todo mundo precisa de Ogún. Ohun gbogbo é o povo, é todo mundo" (Carvalho, 1992, p.74).

Pai Paulo sempre fazia referência a essa cantiga quando narrava sua viagem para a Nigéria em 2013: “Aí me levaram para ver Ogum lá em Ilê-Ifé, cheguei lá e cantei para Ogum. Fui cantando e ia puxando a letra assim, alongando, e eles olhando, cantei como meu pai e meu tio cantavam".

A toada faz referência a uma das principais características de Ogum: o ferro.

Em geral, o assentamento de Ogum consiste em um alguidar de barro que funciona como suporte para um conjunto de ferramentas e objetos de metal, em especial uma ou mais espadas, facas e facões. Em vez de pedra, o próprio metal é o otá Ogum. Tal qual Ogum, usa-se o ferro como morada dos orixás Ode, Obaluaie e Ossain. Para todas essas entidades, o próprio ferro é o otá. Sendo assim, recebe o mesmo tipo de cuidado e tratamento ritual.

Um dos principais elementos de ferro encontrados no assentamento de Ogum é a faca, imprescindível nas obrigações. As pessoas do nagô sempre se referem a isso no momento das obrigações em que os animais são imolados. Ogum é sempre invocado nesse ato. Há uma explicação de Pai Paulo, transmitida a Arnaud Halloy, que vale a pena recuperar:

\begin{abstract}
A faca, para ser um instrumento de metal, pertence a Ogum. É isso que esse mesmo pai-de-santo nos conta sobre isso, sempre durante o deká em questão: "Esta faca pertence a Ogum. Ogum ... é o mestre da morte [em que ele pode dar-lhe], ele é o mestre da floresta, ele é o dono da casa ... Ogum leva bruxaria e, portanto, pessoa não duvide da força de Ogum... Ogum mantém a doença e a morte longe de nós! Que esta faca te proteja [dirigindo-se a Cristiano], que ele seja firme para que tudo corra bem!" (Halloy, 2005, p. 514).
\end{abstract}

As facas utilizadas nas obrigações ficam guardadas no peji. Podem ficar em Ogum, mas não necessariamente. De todo modo, toma-se sempre o cuidado de guardá-las nos pejis. Em uma obrigação, elas são retiradas do seu local e, batendo-as no chão com o cabo e a ponta para cima, iniciam-se os trabalhos.

A proximidade mitológica dos orixás é traduzida no peji em termos espaciais e cromáticos. Essa proximidade física e cromática torna-se mais evidente com a semelhança dos assentamentos, o uso do ferro como elemento principal e as cores dos colares em combinações 
de verde. Verde e vermelho para Ogum; verde, vermelho e branco para Ode e verde escuro para Ossayn.

\section{Ode}

Ao lado dos assentamentos de Ogum, fica o assentamento de Ode, tido em Recife como o irmão mais novo de Ogum. Os assentamentos são muito parecidos: um alguidar de barro, no chão, com alguns instrumentos de ferro. A diferença é que o de Ode possui menos ferros, e um arco e flecha de metal (Odemata) figura como proeminente. Um colar é enrolado nessa ferramenta. Esses orixás quase sempre ficam diretamente no solo. A explicação dada sobre isso é que eles são mais ligados a terra, além da própria constituição material dos assentamentos não permitirem muito seu armazenamento nas prateleiras. Em geral, encontra-se não mais do que um assentamento desse orixá nos pejis, pois os filhos de santo de Ode no nagô são raros em comparação com outras nações como jeje ou ketu, onde possui muitos filhos de santo.

Um dos maiores pais de santo do Recife, Tata Raminho de Oxóssi, é um exemplo disso. Raminho era filho de santo das Tias da antiga casa do Pátio do Terço, tendo José Romão como pai de santo e Malaquias como seu padrinho. No nagô, seu orixá era Xangô. Com a morte de José Romão, ele viaja ao Rio de Janeiro e passa a ser filho de santo de Zezinho da Boa Viagem. Ao tomar obrigações com Zezinho, na nação jeje, seu orixá nessa nação é Oxóssi ${ }^{86}$. Raminho, ao retornar a Recife, agora como filho de santo de Oxóssi, torna-se um dos sacerdotes mais populares e importantes, abre um grande terreiro e passa a possuir centenas de filhos de santo. Essa expansão, de acordo com as pessoas com quem convivi, seria efeito da mudança de nação e de orixá. Na casa de Mãe Lu, um dos poucos filhos desse orixá é o antropólogo Arnaud Halloy.

\section{Obaluaiye}

Chegamos agora ao conjunto de orixás que estão no interior da prateleira de cimento, onde se encontram a maioria dos assentamentos do peji. Essas prateleiras ou plataformas são muito parecidas entre si. Em todos os pejis que adentrei durante minha pesquisa (aproximadamente trinta), suas disposições eram mais ou menos padronizadas: ao menos três plataformas horizontais sustentadas por três ou mais colunas verticais. Em cada quadrado, um

\footnotetext{
${ }^{86}$ Muitos enxergam essa mudança não enquanto uma substituição, e sim pelo fato de que no nagô seu segundo santo era oxóssi, e o que ocorreu com a mudança de nação foi que este último "passou a frente". De todo modo, vale notar que Raminho continua cultuando o nagô, paralelamente ao jeje.
} 
conjunto de assentamentos de um santo principal, esse pequeno espaço coberto com azulejos na cor do orixá ou na cor branca. Além dos assentamentos, essas prateleiras são receptáculos de imagens de santos, perfumes, facas utilizadas nas obrigações, fotos ou quadros com santos católicos e, mais recentemente, fotos dos próprios filhos de santo incorporados. Além disso, potes com obi, orobos, pembas e outros axés.

Nas prateleiras inferiores da extremidade esquerda do peji do Ilê Iemanjá Ogunté, próximo à parede que faz divisa com o quarto de balé, encontram-se os assentamentos destinados a Obaluaie, Ossain e Nana e, nos pavimentos superiores, os assentamentos de Oya. Esse conjunto de orixás possui estreita relação cosmológica com os mortos e, a exemplo dos assentamentos descritos, também utilizam o barro na sua composição.

Obaluaiye é também um santo do barro e do ferro. Seu assentamento é um vaso de barro com algumas setas de ferro, variando entre uma ou sete no total. $\mathrm{O}$ assentamento de Obaluaiye possui uma singularidade em relação aos demais: no interior do vaso de barro há uma casca de castanha. Dentro desse recipiente, encontram-se dois chifres de bode e alguns gigatas (uma pequena cruz feita dos ossos da mandíbula inferior dos "animais de quatro patas" sacrificados), formando um arranjo com penas e uma seta de metal ${ }^{87}$.

Obaluaiye é um santo que não possui muitos filhos de santo no nagô. É tido como um santo pesado, de difícil trato, além de ser um dos poucos orixás invocados no balé, onde é evocado como Ologbojo.

O principal assentamento dessa divindade no Ilê Iemanjá Ogunté pertencia a uma antiga mãe de santo, Maria Romana. Esse assentamento foi herdado por Pai Paulo e hoje pertence a Paulinho. Em 2015, parte desse assentamento estava se desfazendo; com o passar dos anos, a parte de barro dava sinais de desgaste profundo. Junior Boto alertou Pai Paulo e ele então jogou para saber se poderia substituir o vaso de barro. Após a resposta positiva, Boto comprou um bonito vaso para fazer a troca. A ocasião escolhida foi a obrigação anual para a Iemanjá da casa. Entre os preparativos da obrigação, Pai Paulo pede para que Boto reorganize o antigo assentamento dentro desse novo e diz para preparar o fundamento do axé, colocando os pós nas cores branco, preto e vermelho. Enquanto seu sobrinho fazia isso, Pai Paulo me perguntou se eu saberia o porquê de ele estar preparando o assentamento usando esses três pós - mais especificamente, o porquê dessas três cores, as quais ele chamou de "cores primordiais".

\footnotetext{
${ }^{87}$ Há uma pequena divergência nesse ponto dado que Arnaud Hallouy afirma não ter encontrado essa seta, e sobre isso descreveu: "Curiosamente, não encontrei uma estrutura contendo sete setas como a descrita por Carvalho (1984: 122), o que revela uma maior variabilidade na composição do assentamento desse orixá.” (Halloy, 2005, p. $505)$.
} 
Imaginei que seria uma explicação similar à dada por Juana Elbein dos Santos (1970), sobre os três tipos de sangue. Esbocei, então, uma resposta nessa linha. No entanto, arrancando o riso de todos os presentes, Pai Paulo me disse gargalhando que essas eram as cores do [time de futebol] Santa Cruz, por isso eram as cores primordiais.

\section{Ossayin}

Atrás do assentamento de Obaluaiye, escondido em um canto da parede, encontra-se o assentamento de Ossain ${ }^{88}$. Em outros terreiros encontrei Ossain assentado em uma pequena casa, próximo à cozinha onde trabalham os ogans ou ao próprio balé, mas, na maioria das casas, o assentamento estava no peji. Está sempre coberto com um pano vermelho, pois dizem que Ossaim não pode ser visto por mulheres e por isso encontra-se o tempo todo escondido sob o tecido. Ossaim não possui filhos de santo no nagô. Assim, cada casa tem apenas um assentamento dessa divindade, que se constitui de uma ferramenta de ferro num vaso de barro. Todos os assentamentos descritos até aqui guardam uma unidade, tanto na disposição física e na proximidade entre eles no peji, quanto na composição de seus assentamentos, pelo uso do ferro em seus emblemas e pelo barro de seus receptáculos.

Bino diz que o Ossain é "fogo" e por isso deve ser escondido. Ele se parece com um redemoinho de vento, um assobio ou, ainda, com a cabeça de um cachorro. "Ele é fogo pras causas impossíveis!"

\section{Nana}

Ao lado desses santos, fica o assentamento de Nana. Mãe de Obaluaiye, ela é considerada em Recife como a avó de todos os orixás. Não conheci filhas de santo de Nana no nagô ao longo do meu trabalho de campo, embora tenha tido notícia da existência de filhas desse orixá em casas Xambá e de Raminho de Oxóssi.

O assentamento de Nana é um quartilhão de barro, com moedas e outros elementos em seu interior, além de um alguidar de barro que fica como tampa do pote, onde são feitos os

\footnotetext{
${ }^{88}$ José Jorge de Carvalho relata que durante sua pesquisa Ossain estava guardado no Balé do Sítio.
} 
sacrifícios. Todos os animais oferecidos a Nana devem ser cortados com vidro, embora recentemente tenha-se adotado facas de porcelana.

\section{Oya}

Oya, ou Iyansan, é um dos orixás mais populares do nagô. Seu assentamento ocupa o quadrante superior esquerdo da prateleira do peji. É composto por uma terrina (sopeira) de porcelana marrom ou cor-de-rosa - os orixás assentados em uma terrina também são chamados como orixás de louça ou porcelana, ou ainda de peças de barro. Como todos os demais orixás femininos, o assentamento de Oya é coberto. Dentro dessa sopeira - sempre coberta por um prato, retirado do conjunto que acompanham esses assentamentos - fica seu otá (que pode ser nas cores marrom, vermelho ou mesmo totalmente preto) e um colar de contas marrom ou rosa, além de búzios e moedas antigas. Um rabo de cavalo e uma espada ficam próximos ou sobre seu assentamento.

As pessoas insistem que esses objetos são usados porque Oya é uma santa guerreira que domina os eguns, espíritos dos mortos. Por isso ela é cultuada tanto no peji quanto no balé. Mas isso não faz dela duas entidades distintas. Pai Paulo dizia que não existe "Oya do balé”, pois "Oya é Oya": "meu pai sempre dizia que se você tirasse Oya do peji e levasse pro balé, ou pegasse a Oya que está no balé e levasse pro peji, elas trabalhariam do mesmo jeito. São o mesmo orixá". Sobre isso, escreveu José Jorge de Carvalho:

\footnotetext{
Ela é o único santo que pertence ao mesmo tempo ao quarto do santo e ao quarto do egun. Os membros enfatizam que é o mesmo santo, iyansan, e não dois; sempre que ela está no quarto do santo ela recebe o nome de Oya Orisa (Oya é outro nome usado às vezes para Iyansan); e quando ela está no quarto do egun, ela é Oya Egun. Então, há um assentamento de Iyansan perto dos eguns, bem como os que estão dentro da sala do santo. Dizem que ela é extremamente poderosa, uma guerreira, vinda de um país diferente de todos os outros orixás: enquanto os outros são Nago, um membro do culto me contou: Iyansan veio da terra de Tapa. Essa característica de ser estrangeiro parece estar presente em alguns aspectos de seu simbolismo. Dizem que ela é a rainha do carnaval; como o quarto de santo está fechado durante esses dias, e os outros santos tendem a deixar a terra, ela fica por perto, protegendo a casa contra qualquer possível invasão de maus espíritos, Esus ou eguns obscuros, que tendem a se mover livremente durante os dias de carnaval. Iyansan é unanimemente associada a Santa Bárbara e seu dia anual é 4 de dezembro (Carvalho, 1984, p. 89).
}

Essa "alteridade" incide em seu posicionamento no peji. Ela fica próxima da parede que faz a divisa com o território dos eguns, e seu assentamento fica no extremo de uma faixa que vai dos orixás aos eguns, cujo outro extremo estaria Xangô. Isso nos remete à ideia, apontada no início do capítulo, de que o posicionamento dos assentamentos no peji indica a incidência 
de uma predisposição cosmológica da relação entre os orixás no universo nagô. Assim, uma das principais justificativas sobre a disposição dos assentamentos encontra-se no tipo de relação entre as divindades. Tais relações são traduzidas em termos de parentesco. Desse modo, ficam próximos, no peji, os orixás que estabelecem entre si relações de "filiação" (Obaluaiye e Nana), de "germanidade" (Ogum e Ode) ou de "afinidade" (Orunmila e Oxum). Esses termos de parentescos são expressos ainda em função de dois verbos essenciais para evidenciar a relação entre um orixá e outro e entre estes e as pessoas: os verbos comer e trabalhar. Os orixás que têm uma proximidade cosmológica, “comem” juntos durante as obrigações.

Paradoxalmente, ainda que a relação entre Oya e Xangô seja sempre explicitada nos termos de sua afinidade - Oya é tida como esposa de Xangô -, esse é um caso em que essa relação não é traduzida em termos da proximidade espacial de seus assentamentos. A elaboração por parte das pessoas do nagô sobre esse ponto recai sobre o impedimento de Oya "comer" conjuntamente com Xangô, devido à forte rejeição que ela teria por carne de carneiro (animal por excelência de Xangô e Iemanjá). Esse impedimento é sempre evocado para justificar a localização em extremidades opostas que esses orixás ocupam no peji. Há terreiros em que Oya ocupa um espaço apartado dos outros orixás. Outro orixá que também compartilha dessa relativa distância com os demais, motivada por impedimentos alimentares, é Orixalá.

\section{Orixalá}

$\mathrm{Na}$ extremidade direita do peji, ocupando todos os três pavimentos, encontramos os assentamentos de Orixalá. Sua localização é justificada pela relação que possui com Iemanjá, de quem seria marido, além de ser considerado o pai de todos os outros orixás.

Seu assentamento consiste em uma sopeira branca colocada em uma bacia de aço inox ou ágata e coberta por um prato branco. No interior da sopeira, ficam os otás de diversas cores próximas de tons claros, bem como os fios de conta de cor branca, cascas de caracóis e moedas antigas.

Mãe Lu sempre alude ao fato de seu Orixalá ser um otá bem pequeno e bem escuro:

"Meu Orixalá é bem pretinho, desse tamanho [sinaliza marcando a distância da unha de seu polegar]. Meu pai quem me deu. Ele dizia que o Orixalá de meu avô era assim também, bem pequeno e bem pretinho, que ele tinha muito cuidado com esse otá. Eu tenho os mesmos santos de meu avô, a mesma dijina: Omitòòùn. Meu Orixalá é o mesmo que o dele, às vezes, eu acho que talvez 
seja o mesmo otá, que ele me deu o otá que era do meu avô, que ele deu um jeito de guardar, não sei..."

Os pratos que acompanham o assentamento de Orixalá são usados para se colocar o egbo, também chamado de arroz de Orixalá. Toda sexta-feira, ao final do dia, acorrem ao terreiro os filhos de santo para o Osé de Orixalá. O arroz frio é colocado nos pratos da entidade: molda-se o arroz cozido sem temperos em formato de um bolo, com um furo no centro. Enquanto as pessoas se ajoelham, a mãe de santo ou um dos ogans pega o sino que fica ao lado do assentamento de Orixalá e começa a invocá-lo em seus múltiplos seres: Orixalá velho, Olufan, o moço e guerreiro Oguian e Orixá Oko. Uma longa sequência de cânticos ao velho orixá é entoada e as pessoas seguram em suas cabeças o prato com arroz para fazer seus pedidos. Um a um, os pratos são retirados da cabeça das pessoas e colocados sobre os assentamentos. O Orixalá da casa fica ao chão, embora os outros permaneçam nas prateleiras. Esses pratos com arroz são cobertos com uma generosa quantidade de mel. Ao fim, a mãe de santo senta-se na porta do peji e realiza um jogo de búzios para saber qual o recado para os filhos de santo da casa. Na virada do ano, esse ritual é realizado entre as $23 \mathrm{~h} 30 \mathrm{~min}$ e meia-noite.

O arroz também é utilizado para fazer a canja de Orixalá no momento do Iyanlé dele. Orixalá come galinhas brancas, cabras brancas e o caramujo arua ${ }^{89}$, embora atualmente utilizese também uma variedade africana de caramujo, Achatina fulica, que foi introduzida no Brasil nos anos 90

Orixalá não pode comer nada que tenha contato com azeite-de-dendê. Por isso, quase sempre sua obrigação se dá após a de Obaluaiê ou Nana, antes dos orixás femininos. A explicação que recebi é que o procedimento intenciona evitar qualquer contato com o azeite de dendê que corre abundantemente ao longo das outras obrigações e também para que sua comida possa esfriar a tempo para não atrasar o Iyanlé. A preocupação com esse contato é similar ao contato de Oya com o carneiro, de tal modo que em muitas casas existe um quarto exclusivo para esse orixá (como nas casas de Maria das Dores, Guara e Zite). Essa localização é mantida na relação do peji quase como uma extensão dessa disposição espacial.

Xangô

Em uma prateleira exclusiva, Xangô com suas gamelas de madeira, seus pilões e oxês, é o orixá mais próximo da entrada, à direita, em posição simétrica a Exu. Curiosamente, várias

\footnotetext{
${ }^{89}$ Megalobulimus oblongus.
} 
vezes pude ouvir que Xangô era o orixá mais próximo dos seres humanos, aquele que estava sempre junto de seu povo. Ele possui um grande número de filhos e filhas de santo. Sua popularidade é tal que, há muito, seu nome designa o culto aos orixás em Recife.

Pai Paulo me dizia sobre Xangô: “O que é o Xangô? É o único orixá que está ao lado de seu povo. Muitos já partiram para Ilê-Ifé. Ele é o único que tá aqui, sofrendo com a gente, na alegria e na tristeza. Odé, Obaluaiê, são todos orixás comandados por Xangô. Egum é comandado por Xangô".

A relação entre Xangô e os eguns, como atesta Pai Paulo, é sempre evocada, justificando a relação de intimidade que esse orixá, ao seu modo, mantém com os eguns, e reforçando, ao mesmo tempo, a distância espacial entre eles. Durante uma obrigação de balé, um ogan me disse que Xangô era o único orixá a usar o guizo:

“O guizo, para o povo iorubá, é o símbolo do nascimento e da morte, um iorubá escuta o som do guizo quando é iyawo, quando tá nascendo pro santo e quando morre, no bata, o tambor dos eguns. Um dia, Xangô fez uma festa no palácio dele e o último a chegar foi Egum; ele veio e dançou em honra de Xangô. Xangô ficou encantado com a roupa do Egum e disse: 'eu quero usar sua roupa', e o Egum disse: 'você não pode usar minha roupa porque ela é a morte, mas você pode usar meu guizo', o guizo parado está morto, mas se movimentando é vivo."

Arnaud Halloy aponta ainda uma peculiaridade em relação à localização do Xangô no peji do Sítio, e que se estendeu a todos os pejis que encontrei durante minha pesquisa:

Xangô também pode ser representado pelo pilão e sua argamassa. Vários pilões são
armazenados no peji em questão. Um deles também contém pedaços de papel nos
quais são escritos saudações e votos, velas, notas de dinheiro (50,100 e 500 cruzados)
e um chocalho na forma de boi, o símbolo de machado duplo deste orixá. Certos
critérios específicos do terreiro e a história de seus dignitários também podem
justificar o posicionamento espacial de certos orixás. No caso de Xangô, o que chamei
de isolar ajuda a enfatizar sua importância no terreiro. Esta importância está
relacionada, em particular, ao lugar ocupado por este orixá na vida de Pai Adão, um
dos mais ilustres antepassados da família. Várias histórias contadas muitas vezes
relatam a ajuda concedida por Xangô ao pai-de-santo em situações financeiras críticas.
Esta referência ao passado do Orixá na comunidade contribui claramente para o seu
desenvolvimento aos olhos dos membros atuais. O link para este orixá está ancorado
em uma história familiar muito carregada emocionalmente (Halloy, 2005, p.446).

O assentamento de Xangô é, por excelência, a gamela de madeira, podendo ou não ser abrigada sobre um pilão. Os otás de Xangô, quase sempre no plural porque costumam ser abundantes, são preferencialmente o corisco ou pedra-raio (machado neolítico). Em geral, usam-se grandes seixos de rio escuros como otás, que, a exemplo dos orixás de ferro, estão 
sempre descobertos. Sobre as pedras, estão numerosos colares de contas vermelhas e brancas, além de oxês (machados) de madeira e coroas. Outra relíquia de Xangô que está no terreiro é o pilão do Xangô de Pai Adão, ainda que seu assentamento tenha sido roubado pela polícia após a morte dele. O xére, instrumento cilíndrico com a ponta em forma de cone, é usado para invocálo durante suas obrigações e fica próximo ou mesmo sobre o assentamento. Um dos mais importantes assentamentos de Xangô da família é o de Bamgbose, antigo assentamento de Tomé, neto de Pai Adão, e quem, segundo Pai Paulo, era filho de santo de Martiniano Eliseu do Bonfim, de Salvador.

Xangô é, sem dúvida, o orixá mais voraz do panteão nagô. Idelfonso conta que sua mãe de santo, Isaura de Xangô Aduban, dizia que não se devia cantar para Xangô sem ter o que dar de comer para ele, e que, se alguém cantasse e ele chegasse, tinha que correr e preparar um beguiri ou dar dois galos para Adubam. Como vimos, seu animal dileto é o Agbo (carneiro) e grandes galos. Nas obrigações, esses animais costumam ser oferecidos em abundância (se as condições financeiras assim o permitirem).

O Xangô da casa é o próprio Xangô de Malaquias, o único que está sobre um pilão de madeira no peji (os outros estão no interior das prateleiras), em uma grande gamela contendo várias pedras negras. Mãe Lu diz que o otá mais antigo é uma pedra em forma de machado que seria do Xangô de Tia Inês, herdado por Malaquias. Tanto Carvalho quanto Halloy fazem alusão ao corisco especial sobre o qual a entidade era assentada: uma pedra na forma de uma cabeça de carneiro. Essa pedra se perdeu recentemente, quando um filho de santo, no processo de limpeza desse assentamento após um beguiri, acabou por colocá-la, em um momento de descuido, no ebó que foi despachado. Até hoje, lamenta-se o ocorrido. "Era a pedra do Xangô de meu avô", disse Boto, "sempre sofro com isso".

Sobre esse episódio, Mãe Lu lembra que Xangô viera lhe avisar por meio de um sonho que tinha partido - uma parte dele ao menos -, e que isso acarretou em uma doença de mais de uma semana que lhe deixou de cama:

"Ele veio me dizer que tinham botado fora ele. Ninguém teve coragem de me contar isso e Xangô veio dizer que tinha partido. Eu sonhei com um homem bem gordo e bem negro, com a boca vermelha e os dentes bem brancos. Ele me dizia "estou indo embora!". E se foi, quando acordei, eu sabia que ele tinha ido, aí os meninos me falaram que o otá tinha ido embora no ebó..."

Atualmente, um dos principais assentamentos de Xangô é o de Junior Boto, que exerce suas atividades como pai de santo no terreiro - isso não se confunde com uma atuação como 
pai de santo do terreiro, à medida que ele oficia algumas obrigações da casa, que via de regra estão sob a execução de Bino, enquanto as obrigações para os orixás da casa ficam aos cuidados de Cicinho ou Guara. Cada obrigação é realizada conforme as "hierarquias", dizem no terreiro.

Mais jovem que os demais, Boto cria sua família com o ofício de pai de santo. Possui um crescente conjunto de filhos de santo, jovens em sua maioria, ligados ao maracatu do Alto José do Pinho. É também pai de santo de alguns filhos de santo antigos, que possuem casa própria, e cujas iniciações são realizadas no Ilê Iemanjá Ogunté. Ele divide com Mãe Lu a responsabilidade dessas feituras. Quase todos seus filhos de santo têm seu orixá assentado junto aos orixás do terreiro, ao menos o principal; contudo, os santos secundários têm seus otás junto aos dos orixás de Junior e ao menos os filhos de santo do mesmo orixá estão em seu próprio assentamento de Orixalá e de Xangô. Marcio, irmão de sangue de Junior, tem seu Xangô junto ao do irmão.

Tal prática é comum nos terreiros nagôs em Recife. Não apenas jovens filhos e filhas de santos podem ter os otás de seus santos no assentamento de seus iniciadores, como é costume que parentes de sangue compartilhem um mesmo assentamento. Trata-se de uma demonstração de confiança e cuidado, quando se abre a possibilidade de que santos de outras pessoas morem no assentamento de seu próprio orixá.

Bino, contudo, alerta que há alguns riscos implicados na operação que se efetua quando se guarda o otá de alguém junto ao seu assentamento ou da casa. Ele me ensina que quando o santo está no assentamento da casa, por exemplo, a pessoa também deverá cumprir o resguardo toda vez que aquele santo comer. Outro ponto é que, uma vez no assentamento, se a pessoa depois quiser retirar seu otá para fazer um arranjo mais exclusivo, há a chance de o orixá não aceitar, preferindo residir onde foi colocado pela primeira vez. Esse foi o caso do pai de santo Roberto, filho adotivo de Dona das Dores, importante mãe de santo do Recife:

[...] quando meu avô Zé Romão faleceu, ela ficou com o tio Malaquías e depois com o Papai (Manoel). Então José veio do outro lado e eu me afastei um pouco. Realmente minha vida era viajar, caminhar. Ela até ficou brava com isso, mas eu disse a ela: quando chegar o dia e a hora de cuidar do orixá, eu volto, e ela me disse: E seu santo? E eu disse: você cuida disso e ela continuou zelando meu santo até o dia em que pôde e quando não pôde mais, me procurou para me enviar seu santo e o meu que morava dentro do santo dela.

Então, seu santo morava dentro do dela?

"Ele sempre viveu dentro do dela" (Depoimento do Falecido Pai de Santo Roberto para Aislan Vieira) (Sarduy, 2014, p. 350).

Nesses casos, podemos dizer que cada assentamento em si é virtualmente um terreiro; pois na medida em que os santos de outras pessoas são incorporados em seu interior, eles podem 
ser extraídos enquanto individuações posteriores quando se abre um novo peji em uma outra casa, levando-se em conta, para tanto, questões de espaço, condições financeiras e, principalmente, a vontade do orixá.

Levar um assentamento para sua própria "casa" implica na criação de um potencial terreiro - digo potencial, pois sua efetivação depende de outros fatores para além do mero deslocamento ou criação de um espaço apropriado. A Casa de Dão, por exemplo, apesar de possuir toda a estrutura de um terreiro, não é considerado uma "casa aberta" no sentido forte do termo, pois não há ali iniciações e grandes festas regulares, somente obrigações menores do proprietário e sua família de sangue. Eventualmente essas casas podem receber uma obrigação para alguma pessoa da família extensa de santo, que, por motivos de alguma briga ou saída da casa de santo, necessite de abrigo para seus orixás por um tempo indeterminado ou somente no período das obrigações para o santo da pessoa em questão. Contudo, ela não será considerada como alguém da casa, nem se fará referência a casa como seu lugar de pertencimento religioso. Nesses casos, a referência sempre será a casa onde o orixá dessa pessoa foi feito ("sou da casa de fulana”) ou onde ele está em definitivo, caso ela mesma seja a proprietária.

De todo modo, retirar o assentamento da casa onde a pessoa foi feita implica em diversos riscos e tensões - o que nem sempre é um processo tranquilo e bem aceito pelas pessoas do lugar de origem. As narrativas sobre a fundação de terreiros evidenciam esse processo, quase sempre advindo de uma cisma ou briga anterior que foi o ensejo da criação. Contudo, condicionar esse fator como determinante na criação de terreiros seria, para dizer o mínimo, ficar na superfície da questão. Há diversas forças em jogo e muitas vezes o movimento de retirar o santo e abrir uma casa é um acontecimento dentro de uma série de pequenas, mas decisivas, partidas.

\section{Iroko}

Nos fundos do Sítio do Pai Adão, ergue-se o imponente pé de Iroko (gameleira-branca, Fícus doliaria). Trazido da África pela fundadora do Sítio, Tia Inês Fatinuke, calcula-se que essa árvore tenha mais de 150 anos. Carvalho (1984, p.145) observa que Iroko é uma árvore que seria o próprio orixá: não havendo assentamentos, a própria planta é o santo, nas palavras do povo do terreiro. Halloy (onde), por sua vez, indica que outras pessoas consideravam a árvore como a moradia do orixá Iroko - isso reflete aquilo que vimos anteriormente, de que existe uma tensão na concepção do assentamento ser o orixá ou ser a moradia do orixá. Diferente de outras nações, no nagô não há pessoas iniciadas como filhas de santo tendo Iroko 
como seu orixá. Sua folha é uma das mais importantes nos preparos dos amassis (a outra é a erioossayin), especialmente nos de iniciação. É um dos principais elementos recebidos por alguém no momento da entrega de seu Deka ${ }^{90}$.

Há diversos relatos sobre a árvore de Iroko: alguns dizem que existiriam tesouros enterrados em suas raízes, outros contam que a própria Tia Inês despachou parte dos seus santos antes de morrer no interior da árvore. Pai Paulo relatava que em suas raízes era cultuado um egum específico, chamado de Oro ou Oro-Ile. Dizia que, durante as obrigações a Egum, as mulheres se escondiam nas casas e dentro do Sítio, e suas obrigações eram realizadas no próprio pé de Iroko $^{91}$ :

"Iroko, a árvore genealógica, ela nasce sempre com um dendezeiro ou um coqueiro em seu interior. Ele é oco, onde mora Oro. Existem duas raízes apontando para o salão do sítio. Que era uma raiz o assentamento de Oro e outra raiz Iroko e recebiam oferendas na mesma hora, concomitantemente."

Ao longo de minha pesquisa de campo, o pé de Iroko permanecia como um monumento atrás do muro que separava o Sítio da casa de Mãe Lu. Embaixo de seus galhos, entre brincadeiras e namoros, cresceram ao menos três gerações familiares do Sítio. Segundo contam, o Iroko tinha um filho: um pé que começou a florescer na entrada do Sítio de Pai Adão, onde havia um velho pé de Abricó. Com os anos, os morcegos que se alimentam dos frutos do Iroko defecaram sobre esse tronco, fazendo nascer ali uma muda que lentamente foi abraçando seu hospedeiro, terminado por tomá-lo totalmente.

Desde que o muro que cerca o Sítio foi construído, há mais ou menos 20 anos, as pessoas da família que habitavam o lado de fora se ressentiam da exclusão. Não necessariamente em relação ao terreno, mas ao convívio da árvore, da dificuldade em se contornar a longa construção entre uma casa e outrapara participar das obrigações, de colher ervas para os banhos ou jogar conversa fora. Aos poucos, cansados do longínquo contorno, os meninos começaram a fazer pequenos buracos no muro, que serviam como frestas para encurtar as conversas, passar coisas entre casas ou como escada para pular o muro. Esses buracos eram sempre fechados, mas na mesma rapidez que se tampavam uns, abriam-se outros.

Os parentes que aproveitavam as facilidades que os buracos possibilitavam na comunicação entre os terreiros também se preocupavam com os perigos que os mesmos

\footnotetext{
${ }^{90}$ Último estágio iniciatório que confere à pessoa o status de "maioridade" no candomblé, podendo abrir uma casa ou iniciar outras pessoas.

${ }^{91}$ José Jorge de Carvalho (1984 p. 145) descreve Iroko como sendo um orixá guardião das almas dos mortos.
} 
significavam para a segurança do Sítio, em especial para a manutenção do Iroko.Há alguns anos, a árvore sofreu com uma grande infestação de cupim. Um raio também contribuiu para deteriorar uma parte significativa de seu já combalido tronco. Eventualmente a Prefeitura disponibilizava uma poda em seus galhos e tratava do cupim. Mas os parentes gostariam de um cuidado maior, afinal, como questionam eles: “o pé não fora tombado com o Sítio ${ }^{92}$ ? E o Iroko não era para ser protegido por uma praça, com cerca e segurança?”. De todo modo, a árvore seguia sem suas garantias de patrimônio e as pessoas comentavam os perigos que ela corria. Pessoas externas ao Sítio iam consumir drogas sentadas em suas raízes e preservativos eram encontrados junto ao lixo que se avolumava nelas. Pai Paulo dizia, ao ouvir essas admoestações, que o santo ali já devia ter ido embora": "já voltou para a África".

Ao final de 2018, esses problemas culminaram em um grande incêndio, que consumiu parte significativa do tronco do Iroko. Os parentes foram acordados na madrugada com uma grande fumaça, sem conseguir ver quem havia colocado fogo na árvore - embora as evidências apontassem que havia sido intencional. Alguns acusavam vizinhos evangélicos que sempre reclamavam do barulho dos jovens que brincavam embaixo da árvore. Outros diziam que tinha sido alguém que tinha entrado à noite no Sítio para consumir drogas embaixo do Iroko.

Após o incêndio, no início de janeiro de 2019, um grande estrondo assustou os parentes, que rapidamente saíram de suas casas para ver o que tinha ocorrido e perceberam a ausência da grande copa da árvore atrás do muro: o pé de Iroko havia sucumbido. Uma enorme tristeza se abateu sobre todos. Inúmeras fotos e vídeos circulavam pelos grupos de WhatsApp e Facebook. Algumas pessoas responsabilizaram o pai de santo do Sítio por não ter cuidado direito do pé. Outros o defendiam, dizendo que ele não tinha culpa pelo ocorrido. Alguns parentes diziam que os otgãos competentes não tinha cumprido com o combinado de garantir uma proteção à árvore.

Outros sustentam que a árvore desejou retornar para África, como fizeram muitos dos antigos africanos, alguns fundadores das antigas casas de culto no Recife, que, ao final da vida, decidiram retornar para o continente africano. Essa é também a interpretação de Bino:

"Do jeito que a árvore caiu, ela não caiu tombando para um lado ou para o outro, ela caiu desmoronando, não foi? Descendo pra baixo. Ela foi pela terra mesmo, pra Ifé. É isso aí, é como meu Papa Negro [Paulo Braz] cantava e dizia 'bii básáá Tií Wó Gjé. Morélé Ifé tín’beleTiíwá wóo’. Se não existe

\footnotetext{
92 Tem que explicar que o Sítio de Pai Adão foi tombado em xxxx como patrimônio cultural do estado de Pernambuco. Em seguida, pelo IPHAN....
} 
Orixá, voltarei a Ilê Ife. Foi o que o orixá Iroko fez, voltou para sua terra Ilê Ife, África, Nigéria, ele está longe!"

Para Mãe Lu, o Iroko acompanhou seu irmão Paulo. Ela diz que ele se foi junto ao irmão depois que ele morreu. "Ele [o Iroko] se foi depois que Paulo morreu, Paulo era um grande adorador de Iroko, meu pai também, muita tristeza... O Iroko se foi junto.”

\section{CONSIDERAÇÕES FINAIS DO CAPÍTULO}

Como vimos neste capítulo, os orixás, dos quais os assentamentos podem ser entendidos como uma parte ou pertencentes à família, é o que descreve Clara Flaksman (2018, p. 126) com precisão: "os orixás têm famílias próprias e fazem parte de famílias humanas, caracterizandose de maneira a absorver certos traços dessas famílias e ao mesmo tempo emprestar a elas algumas de suas características".

É importante notar que os orixás não simbolizam uma relação de parentesco entre humanos e divindade; na perspectiva das pessoas da família, eles "participam” de seu funcionamento. Suas linhas de filiação e, em menor grau, de aliança (orixás filhos de orixás, orixás esposas ou maridos de outros orixás, humanos filhos de orixás, orixás filhos de humanos, humanos casados com orixás). Divindades, objetos e pessoas compartilham, de maneiras diferentes, de uma mesma rede de participações e um mesmo léxico ${ }^{93}$. Ambos surgem como pontos em um diagrama, dispostos em termos de parentesco: mãe, pai, filho, filha, esposa, marido.

Nesse sentido, os orixás não reproduzem as relações familiares entre si como se fosse um espelhamento daquelas estabelecidas pelos humanos. Essa conotação do parentesco para pensar a relação entre divindades e destas com os humanos não é uma abstração meramente incidental, ela é também um dispositivo espacial, ou, como coloca. Miriam Rabelo (2014, p.

\footnotetext{
${ }^{93} \mathrm{O}$ modo de existência dos santos não é o mesmo modo de existência das pessoas nessa rede.
} 
207), “assim como a ponte posiciona e põe em relação o rio e suas margens, os assentamentos posicionam os integrantes do terreiro, organizam suas relações". Essa caracteristca não se restringe aos santos e suas moradas, infletindo também nas relações entre humanos e espíritos pois, como formulam meus anfitriões, “os orixás são nossos pais e mães, eles moram com a gente!"’. As narrativas sobre os orixás e seus assentamentos descrevem diferentes modos de habitar e percorrer lugares ancestrais, locais em que vivem ou habitaram tanto os orixás quanto seus parentes, sendo desde as histórias dos orixás de um peji, a relação com a fundação de uma casa, a origem do Sítio de Pai Adão e, mesmo, a África.

Tais conceituações territoriais se apresentam de modos múltiplos, por vezes divergentes. No caso do peji do Ilê Iemanjá Ogunté, para além de uma narrativa de origem, há uma descrição de um modo de relação: os orixás foram assentados no terreiro Ilê Ogunté tal como o eram no Sítio. A própria disposição dos santos no peji parece obedecer à mesma organização topológica que lá seguiam. Essa referência permite imaginar que a separação do Sítio com o terreiro de Mãe Lu é mais "atual” do que "real” e, por extensão, podemos supor o mesmo em relação a esses dois terreiros com a própria África. Contudo - e esse ponto é crucial -, o que as narrativas parecem informar é que a disposição dos santos, sua existência ou ausência em relação ao peji do Sítio, não se impõe como uma origem dos últimos em relação aos primeiros, mas sim que os pejis surgem como versões do outro.

É preciso sinalizar que essa composição, expressa em termos de descendência e baseada em linhas de filiação, é elaborada por meio da noção das "heranças espirituais", tema do próximo capítulo. Tal concepção pode ser entendida, aqui, na perspectiva de um modo de existir que engloba, distingue, transforma e relaciona lugares, objetos, pessoas e divindades. Não só os terreiros podem ser pensados nesses termos, mas o próprio peji seria percebido como efeito desse modo de existência.

A relação com os santos e os assentamentos é pensada também por meio da noção de descendência, através de seus ancestrais e de sua herança. Como veremos, essa descendência é performada por meio dos vínculos que os assentamentos evocam nos diversos terreiros dessa família, que reproduzem no interior de seus pejis a disposição topológica dos santos e a separação espacial deles com os eguns encontradas no nagô.

Os pejis, portanto, oferecem uma dimensão física, uma materialização desses espaços segmentados (espaço dos orixás, espaço “africano", espaço como o do Sítio) - algo que Scott (2007) vai chamar de "colocação cosmológica": lugares que se relacionam com outros espaços, materializados pelos assentamentos dos santos que habitam em seu interior. Mais que uma 
reprodução desses espaços, o peji permite também um modo de interação por meio de sua "participação".

Assim como os pejis, os próprios assentamentos permitem visualizar como uma multiplicidade de coisas é postas em conexão no candomblé (pessoas, objetos, espíritos, orixás, lugares). Não só o peji é um dispositivo que atua agrupando e separando entidades distintas, como o próprio assentamento pode ser visto como um agregado de uma heterogeneidade primeira, embora o faça de modos distintos. O peji agrega um conjunto de entidades dispostas de acordo com suas relações (traduzidas por termos de parentesco), que incide na distância e na proximidade das próprias divindades nesse local. O peji, enquanto um domínio ritual, é separado e apartado dos eguns. Os assentamentos, por outro lado, congregam em seu interior diferentes pessoas de uma mesma rede de parentesco, vinculadas pela filiação a um orixá específico.

No entanto, a separação com os eguns em outros momentos não ocorre do mesmo modo do que no peji. Ao invocar um orixá ou um santo, os eguns de parentes falecidos são chamados para intermediar os pedidos de seus descendentes por meio de sua maior participação e proximidade com os orixás - uma proximidade possível pela sua condição enquanto espíritos. O assentamento permite um outro modo de participação entre ascendentes e descendentes, potencializando uma relação entre vivos e mortos que o espaço do peji não permite.

Pai Paulo dizia que os orixás e eguns estão o tempo todo presentes no cotidiano da família, comendo e trabalhando com e para os seus. Eles, bem como seus assentamentos, são forças poderosas que incidem como fonte de vitalidade e criatividade no universo do nagô. Entretanto, como toda força, essa presença é acompanhada por uma eterna tensão, um perigoso jogo de manejar e reforçar os vínculos por meio dessas participações, de modo que esses vínculos não se percam - evitando, assim, que no limite os santos vão embora para África.

Os assentamentos e suas disposições permitem visualizar o modo como as conexões e vínculos imprescindem de um modelo que se baseie no crescimento da interação entre pessoas e os orixás a partir de um único ponto, a saber, um que se iniciaria nessa própria relação. Retornando ao momento da iniciação, por exemplo, como o ponto que permite a entrada da pessoa na rede de relações da família de santo. De certo modo, a iniciação de uma pessoa torna mais efetiva uma relação que, apesar de já existir, ainda era percebida como vislumbre; ganha sua concretude visível no momento em que o assentamento é criado. Mas esse não é um ponto zero que possa ser tomado como ponto de partida para essa relação. As relações precedem as 
pessoas. Não há uma origem absoluta, pois esta se apresenta apenas como um instante provisório do fluxo dos relacionamentos. Esse é o tema do próximo capítulo. 


\title{
CAPÍtulo 4 - A heranÇA dos SANTOS
}

\author{
"A hierarquia do candomblé é mais uma hierarquia de obrigações \\ que uma hierarquia de direitos"
}

(Bastide, 1958, p. 304)

\section{HERANÇA DE CASAS}

Um dos eventos incontornáveis da história da família Felipe da Costa é o rompimento com o Sítio e o estabelecimento, no início dos anos 80, do Ilê Iemajá Ogunté enquanto terreiro na residência de seu fundador Malaquias Felipe da Costa. Como vimos, desde os idos dos anos 40, com a ascensão de Joana Batista à liderança, Malaquias levou seu assentamento e o de sua esposa do Sítio para sua casa. Ele costumava levar os santos para o Sítio durante as obrigações e depois trazê-los de volta, muitas vezes a contragosto dos orixás.

Esse é um tema sensível. Minha exposição se baseia no que foi dito pelos descendentes de Malaquias, embora eu os apresente com certa cautela. Não mantive relações de pesquisa com Manoel Papai e estive no Sítio por algumas vezes acompanhando as obrigações nesse terreiro. Não obstante, mantenho amizade e contato com parte de seus moradores assíduos nas atividades rituais da região. O que a convivência demonstrou, em muitas situações que presenciei e em conversas que ouvi entre meus anfitriões, foi que as brigas que valiam a pena ser brigadas ou as disputas, e que motivavam e engajavam as pessoas, eram aquelas internas à família.

Poucas vezes vi e ouvi conflitos e disputas entre filhos de santo renderem mais do que alguns dias ou semanas. Além disso, os membros da família costumam criticar o envolvimento dos filhos de santo nas discussões entre parentes. Não obstante, como veremos, é impossível dissociar completamente as brigas de família de santo e de sangue, dado que frequentemente elas também dizem respeito aos orixás e, desse modo, afetam as pessoas que estão vinculadas por essa relação. Por exemplo, um pai de santo que, em uma briga de família, envolva seu círculo de iniciados é tido como alguém "afoito", que "não sabe separar". Muitos filhos de santo se ressentem quando uma briga entre familiares atrapalha o andamento ritual: "estão misturando as coisas". Certa vez, ouvi Pai Paulo fazer uma severa crítica a um filho de santo que havia tomado parte em uma dessas brigas da família: “filho de santo não é parente!”.

Além de ser um evento incontornável para contar a história do Ilê Iemanjá Ogunté, a disputa envolvendo a sucessão do Sítio influenciou fortemente a saída definitiva de Malaquias 
e a ruptura que, em alguma medida, dura até hoje. Trago o episódio à tona por colocar em evidência o modo com que as relações que se deram entre as pessoas foi lido pela literatura, qual seja, pela ótica da “disputa pelo poder". Procurarei aqui reconstituir a história do conflito intercalando descrições etnográficas históricas e outras atuais. Não procuro, com isso, trazer vozes para formar uma possível versão totalizante do evento. Meu interesse é mostrar as noções de herança mobilizadas na compreensão do conflito, o que, veremos, traz ao centro do debate uma crítica à noção de "posse" em relação ao universo dos orixás. Objetivo, ainda, mostrar como outros elementos necessariamente participam das questões e eventos relativos, neste caso, à sucessão.

Após a morte de José Romão, no início dos anos 70, teve início uma disputa pela liderança masculina do Sítio de Pai Adão. O período coincide com a aposentadoria de Malaquias, que trabalhava como contínuo no prédio da Receita Federal, e com o estabelecimento de Manuel Papai enquanto pai de santo em algumas casas da região, em especial na casa de sua avó materna, Lídia Alves, e de sua mãe de santo, Maria das Dores. O próprio pai de santo havia também transformado sua residência em um terreiro.

Como vimos no capítulo sobre parentesco ritual, no nagô do Recife, é comum uma mesma casa de culto ter em seu interior uma composição que permita diferentes pessoas ocuparem um mesmo papel ritual de liderança como pai ou mãe de santo, sobretudo nos casos de interdições entre pais e filhos carnais e pessoas que mantenham relações sexuais entre si. Desse modo, reconhece-se a liderança do pai de santo mais antigo como pai de santo da casa, o mesmo valendo para a mãe de santo. Esses são o pai e mãe da maior parte dos filhos de santo feitos na casa.

Também vimos que uma pessoa que possua uma casa de santo pode oficiar as atividades rituais em casas de diferentes pessoas, a depender da disponibilidade do pai ou mãe de santo. Nesses casos, outras pessoas são convidadas a oficiar no lugar desses líderes. No Ilê IemanjáOgunté, por exemplo, após a morte de Pai Paulo, o pai de santo da casa é seu irmão mais novo, Cicinho. Ele está presente nas principais obrigações da casa, mas todo o trabalho ritual é desempenhado por seus sobrinhos. Além disso, na casa, atuam como pais de santo seus sobrinhos, Bino e Junior Boto, cada um possuindo um conjunto de filhos de santo que sempre 
realizam suas obrigações, no terreiro, tendo Mãe Lu como mãe de santo. As pessoas do terreiro afirmam que assim também o era no Sítio, quando José Romão era vivo.

Figura 2 - Genealogia do Sítio de Pai Adão (Pereira, 1994, p.80).

\section{ESQUEMA: ENTRELAÇAMENTO DO PARENTESCO PROFANO/SAGRADO DO SÍTIO DE PAI ADÁO.}

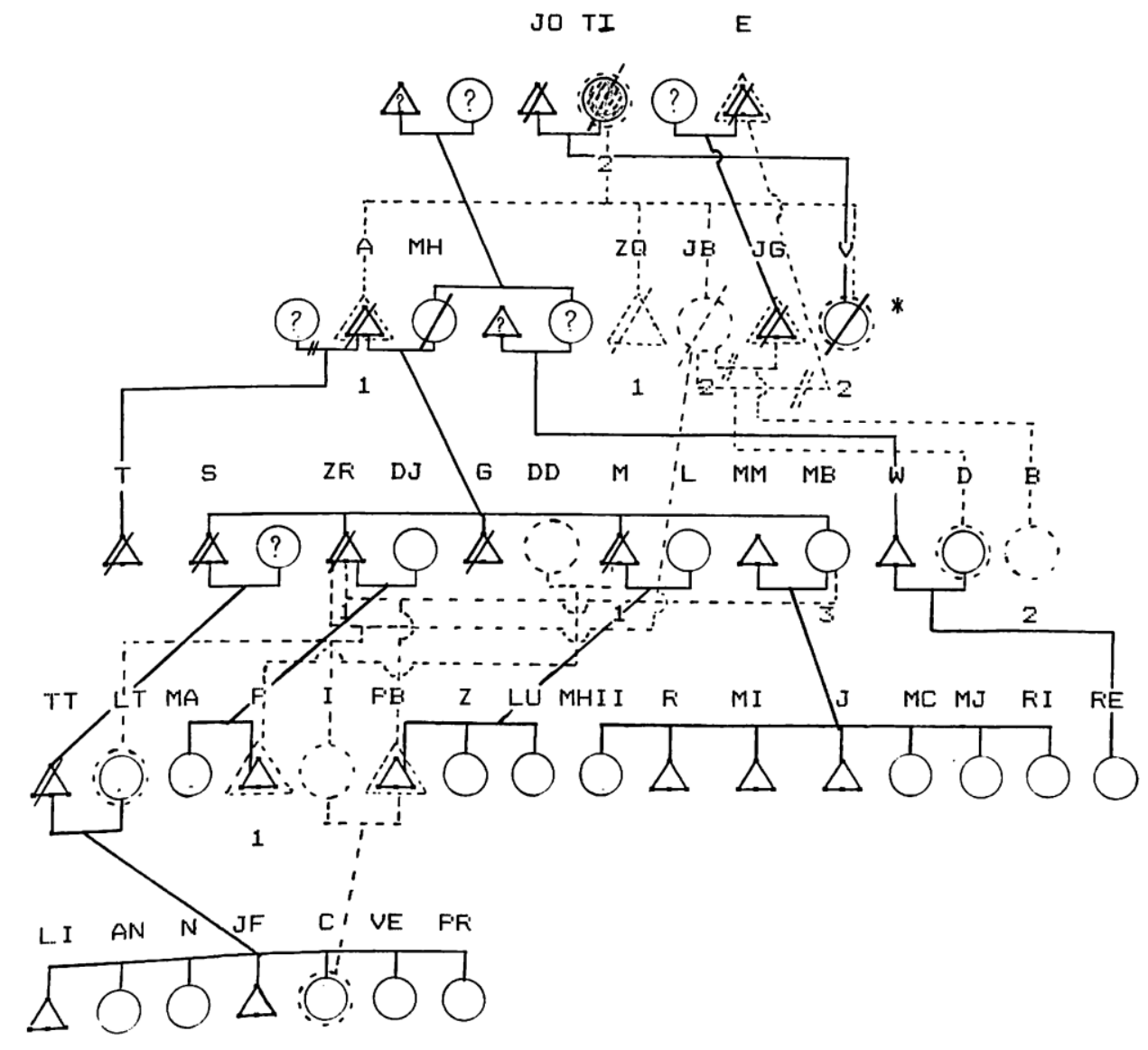

legenda: separạ̧a: 4

parentesco sagrado: $!$

parentesco profano: /

ego: TIA InÊS

nomes nåo identificados: ?? ? 
Figura 3 - Genealogia Sítio de Pai Adão (Pereira, 1994, p.81). 
UFPE Biblioteca Central

- Fais de santo do Sitio

- Mäs de sento do sitio

- Madrinha do Sitio

- Filhe de criaça da Tia Ines

- Jỡo otolú

- Tía Inés

- Eustécquio

- Adáa

- Maria da Hora

- José Querino

- Jeronimo Gomes de Almeida

- Joana Eatista (Bode)

- Vicencia

-.. Teodomiro

- Sigisinundo

- José Fiomâo

- Dijanira

- Guilherme

- Das Dores

- Mal aquias

- Leonidas

- Manoe 1

- Maria do Bonfim (Maezinta)

- Walfrido

-. Dirce

-.. Beleza

-.. Tomé

- Luiza de Tome

- Matilde

- Fapai.

- Izalira

- Faulo Braz

- zite

- Lucinha

MH I I - Maria da Hora I I

F - Foberval

MJ. - Mirinaldo

J - Jốa

MC - Maria do Carmo

MJ - Maria Jose

FI - Filda

FE - Fiejäre

LI - Linduar

AN - AnLInciada

N - Naria

JF - Jose Felipe

C - Céça

VE - Vera

FF - Frazeres 
Segundo Mãe Lu, seu Pai Malaquias e seu tio José Romão se revezavam nas atividades rituais do Sítio, ambos oficiando como pais de santo. Seu tio era o líder do terreiro, por ser mais velho e residir no próprio espaço do Sítio, mas dividia com seu irmão mais novo a maioria das atividades: "um começava e o outro terminava, como deve ser!”. Após a morte de José Romão, Malaquias assumiu sua posição em um grande número de casas, enquanto outras ficaram a cargo de seu sobrinho, Manuel.

A respeito do conflito entre Malaquias e seu sobrinho Manoel, as pessoas sempre disseram que o grande problema foi Manoel ter alegado a posse da terra contra a "hierarquia do Sítio", na qual "morrendo quem está no comando, o mais velho assume". José Jorge de Carvalho, que realizava pesquisa de campo no período, assim descreveu:

José Romão teve somente um filho, Manuel Nascimento da Costa, cuja mãe é Janda, uma filha de Lídia. Manuel, portanto, desde sua infância esteve ligado aos famosos xangôs do Recife; e também herdou o terreno do Sítio. Por outro lado, José Romão determinou que após sua morte seu irmão Malaquias seria o pai de santo do Sítio. Pediu também a Malaquias e Maria das Dores que iniciassem Manuel no canto xangô [...], pois um pai carnal não pode ser o pai de santo do seu próprio filho. Assim Manoel não poder ser o líder da própria casa que herdou em virtude de todas as obrigações para com seu tio. Uma situação de conflito irrompeu entre o tio e o sobrinho quando Manuel recusou-se a aceitar que Malaquias realizasse os sacrifícios para seus santos [...]. Como resultado, Malaquias assumiu o Sítio em 1973 e Manuel decidiu abrir sua própria casa do xangô. Manuel também se estabeleceu como pai de santo de duas casas de muito prestígio: a casa de Lídia, sua avó e a de Maria das Dores, sua própria mãe de santo, que se aliou a ele quando de sua disputa com Malaquias.

Quando realizei meu primeiro período de trabalho de campo em 1976, Malaquias era o responsável pelo Sítio e Manuel estava afastado da antiga casa. No fim daquele ano, Manuel insistiu em seus direitos como herdeiro legítimo e Malaquias resolveu partir, levando consigo toda a sua família. Assim quando voltei em 1977, encontrei Manuel como responsável do Sítio e pela primeira vez foi-me permitido gravar e fotografar ali um festival público. Alguns meses depois de ter deixado o Recife pela segunda vez, cresceu grande descontentamento entre os membros mais antigos do Sítio contra o modo pelo qual Manuel estava orientando a casa. Eles basicamente acusaram-no de não ser maduro o suficiente para assumir responsabilidade tão pesada (ele então tinha uns 37 anos). Após várias discussões, consultas ao oráculo e conversas com a família de Malaquias, Manuel abandonou o Sítio, retirando-se novamente à sua própria casa, à de Lídia e à de Maria das Dores. Malaquias e sua família voltaram em 1978.

Em dezembro de 1979 iniciamos nosso terceiro período de campo, vivendo na casa de Manuel e visitando principalmente as de Lídia e Maria das Dores. Como participamos de vários rituais no Sítio, entretanto, tornou-se para nós muito difícil ficar exclusivamente do lado de Manuel na disputa e por essa razão mudamo-nos de sua casa depois de cinco meses. A partir de então concentramos nosso estudo em grande parte no Sítio, na própria casa de Malaquias e em outras casas onde ele oficiava. Acredito que no fim, obtivemos um bom quadro de como os lados vêem o conflito. Quando deixamos o Recife em agosto de 1980 o relacionamento entre os dois principais líderes xangô era o pior possível. Temos mantido uma correspondência regular com vários amigos, especialmente do Sítio, da casa de Lídia e de Maria das Dores. Fui informado que Manuel reclamou sua condição de proprietário do Sítio mais uma vez e em 1982 expulsou Malaquias e sua família e estabeleceu-se como líder. Não posso dizer se esse último estado de coisas será o definitivo (Carvalho, 1984, p. 59). 
Esse último estado de coisas tem se mantido mais ou menos o mesmo até agora. A "posse" do Sítio, ou seja, o argumento legal de "propriedade da terra" foi evocado como parte da justificativa da ascensão de Manoel Papai como pai de santo do Sítio e deu uma duração específica para a conclusão da sucessão de eventos relativos ao conflito. Adianto que a evocação da posse acionou uma noção de "herança" pouco usual nas regras de sucessão no culto, conforme mostrarei mais detalhadamente. Parece-me curioso que a maior parte dos relatos etnográficos, senão todos, sobre o parentesco de sangue, na perspectiva da família de santo em Recife, exploram esse litígio exclusivamente na chave da herança de propriedade , ao reencontrar na linguagem da disputa o tema do "poder", recorrente nos casos de sucessão dos terreiros.

Pai Paulo vinculava a briga a um descumprimento da tradição do Sítio que, de acordo as pessoas da família do Ilê Yemoja Ogunté, garantia que ninguém poderia ser "herdeiro" do Sítio, dado que o Sítio não pertencia a uma família, sendo propriedade de Tia Inês, Ifatinuké. Tia Inês, ou Ignêz Joaquina da Costa, seria uma princesa da cidade de Ilê-Ifé. Segundo Pai Paulo, esse fato foi confirmado em sua viagem à Nigéria em 2013, onde recordaram o nome Ifatinuké. Ela teria vindo no mesmo navio de Adifabola, João Otolu, pai de pai Adão, com quem "vivia maritalmente" e dividia a liderança do Sítio. Neste mesmo navio veio Claudino, que também fundou o Sítio. Ela teria vindo ao Brasil escravizada e sua família teria enviado dinheiro para a compra de sua alforria, sendo o Sítio a prova de seu poder aquisitivo como uma princesa. Ela seria proprietária ainda de outros imóveis na região: um outro sítio na mesma rua, uma casa no largo do bairro de Água Fria, outras três no bairro vizinho do Arruda.

"O sítio de Pai Adão foi comprado com a finalidade de usufruto dos orixás, ou seja, morrendo um mais velho, outro mais velho assumiria o comando do culto a Yemojá Ogunté", explicou Pai Paulo. Ainda de acordo com sua narrativa, Tia Inês teria registrado o Sítio no nome de Yemojá Ogunté como Pessoa Jurídica. Com o falecimento de Tia Inês em 1916, a responsabilidade de zelar pelos orixás teria sido passada para um filho adotivo seu, José Quirino. Um depoimento do ogan Walfrido para Aída Ester Bueno Sarduy corrobora esse fato:

E depois que ela morreu, quem assumiu o terreiro?

Zé Querino. Aquele que foi criado por ela e que morava com ela. Foi enquanto que o Pai Adão veio. Pai Adão era daqui, mas ele não era responsável por nada aqui. Além disso, ele tinha sua casa lá em Bom Conselho; então ele veio aqui até morrer em 36 (Sarduy, 201, p.246). 
José Quirino teria liderado o terreiro por apenas quatro anos. Mãe Lu diz que ele teve muitos aborrecimentos com as brigas e fofocas e chamou Pai Adão para ocupar seu lugar em 1920. Nesse intervalo, Pai Adão chegou a fundar um terreiro na Rua Bom Conselho, no Bairro do Arruda, dedicado a Ayra Ibonan. Pai Paulo relembra que esse terreiro teve uma curta existência:

Este Ilê era coberto de capim e pegou fogo com as faíscas dos fogos de artifício. Pegou fogo e caiu, só ficou o terreno vazio. Ele não teve condições de levantá-lo novamente. Naquela época tudo era difícil. O terreno era no nome de sua filha e depois da morte do pai, Tia Mãezinha trocou o terreno por uma máquina de costura, a contragosto de seus irmãos.

Após a morte de Pai Adão em 1936, Dona Joana Batista assumiu a liderança do terreiro até 1953, tendo como seu Asipa José Romão, filho consanguíneo de Pai Adão. Como no nagô o pai carnal não pode iniciar seus filhos, José Romão era filho de santo de Dona Joana com Pedro Olubade. Malaquias, por sua vez, era filho de santo do famoso sacerdote Martiniano Eliseu do Bonfim. Sobre os outros filhos de pai Adão não se costuma relembrar a filiação de santo.

Voltando às memórias de Pai Paulo, com a morte de Tia Inês, deram como herança a outra casa dela no bairro do Arruda para Pai Adão, que a recusou: "Meu pai não possui nenhuma propriedade e não me deixou nada”. Essa mesma frase teria sido dita por Malaquias, sessenta anos depois, quando confrontado pelo sobrinho e filho de santo acerca da propriedade do terreno.

Cumprindo os preceitos, meu pai entregou o comando do Sítio de Pai Adão para Joana Batista, Joana Bode, por ser a filha de santo mais velha de Tia Ignez e de Pai Adão. Como meu pai demorou a entregar o sítio, Joana Batista prestou queixa à polícia. Por isto minha avó Mariazinha nunca mais quis entrar no sítio, não passava nem na frente. Ela faleceu no dia 26 de maio de 1945. Chovia muito neste dia. A Estrada Velha de Água Fria estava alagada com as águas que escorriam dos morros e dos córregos. Aproveitaram as águas para jogar fora o travesseiro, colchão, roupas e outros pertences, $e$, por ironia do destino, o cortejo fúnebre não passou na frente do sítio. Entrou na rua do Cariri rumo ao cemitério de Beberibe. (Pai Paulo)

Figura 4 -Esquema Cronológico de Sucessão do Sítio de Pai Adão (Pereira, 1994, p.82). 
ESQUEMA CRONOLÓGICO DA SUCESSĀO DO SítIO dO PAI ADĀo

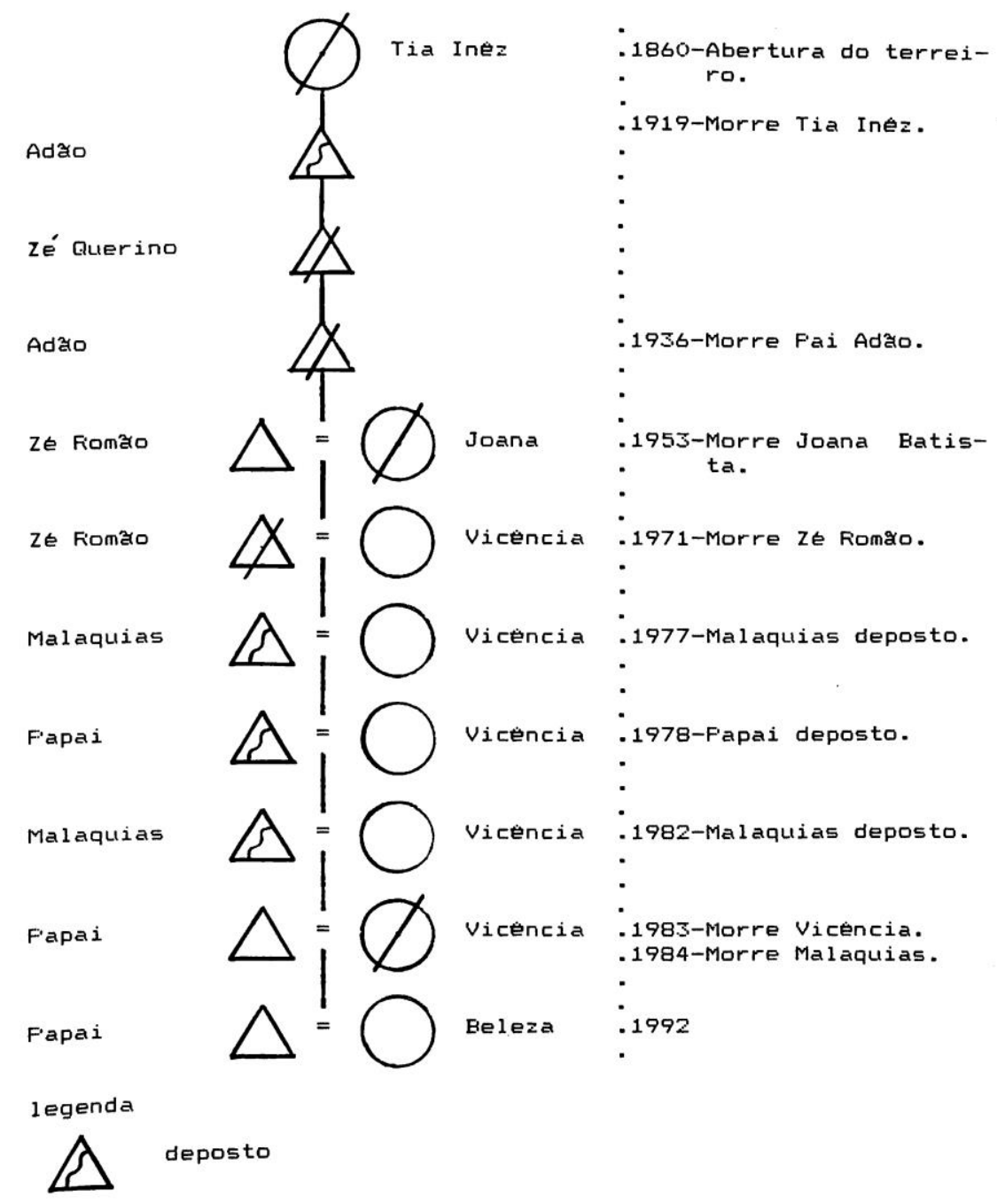

.82

As narrativas colocam algumas questões no diagrama acima. De acordo com Pai Paulo, na época de Tia Inês, a liderança masculina do Sítio ficou com João Otolu Bioka, depois passou para José Quirimano e, por fim, para Adão. Na época, as narrativas contavam que Joana Batista ocupava a posição de mãe de santo, o que sugere uma das possíveis fontes dos desentendimentos entre os dois. Uma das ressalvas que faço em relação ao diagrama de Zuleica Dantas é que ele somente considera a liderança do terreiro, com posições de pais e mãe de santo a partir da morte de Adão. Pai Paulo sempre lembrava que João Otolu Bioka era o pai de santo 
de Pai Adão e que teria falecido na viagem que levou Adão à África. Segundo Pai Paulo, ao retornar para o Brasil, o pai de santo de Adão passou a ser um famoso sacerdote que vivia no Rio de Janeiro, de nome João Alagba. Tia Inês, por sua vez, fora sempre a única mãe de santo de Adão e, com sua morte, por ocasião de seus oboris, ele pedia para a própria esposa soprar $o$ axé em sua cabeça.

Pai Paulo faz alusão à transmissão da liderança de Pai Adão para Joana Batista como um preceito. Preceito e tradição exprimem dois importantes conceitos do mundo candomblé. Ao aludir assim à sucessão, Pai Paulo exprime o caráter impositivo que esse ato investe. Preceito é algo que as pessoas devem cumprir rigorosamente ao entrar em relação com as divindades. Esse imperativo das divindades deve ser percebido como algo além da vontade humana - nesse caso, o desejo de Malaquias em continuar no Sítio. Como transparece nas falas e depoimentos, a relação entre Adão e Joana Batista era conflituosa ao ponto que parte da família de Adão deixou de residir no Sítio após sua morte. Malaquias, por exemplo, nunca mais regressou ao Sítio como morador e daquele ponto em diante, constituiu sua residência fora de seus limites. Mas naquela época "resguardou-se a tradição":

D. Joaninha não assumiu antes, porque tinha medo de Adão. Quando havia toque no Sítio, mandava suas filhas irem, mas ela nunca ia. Mas o principal medo de DJoaninha era o da responsabilidade com o quarto de balé. Finalmente quando Adão morreu. D. Joaninha foi para o Sítio e assumiu juntamente com Zé Romão..., todos ficaram intrigados quando ela assumiu, pois o terreiro era 'dele'. Minha madrinha antes de ir pro Sítio, tinha seu próprio terreiro em Ponto de Parada, os filhos de Adão, Mundinho e Zé Romão, viviam na casa de D. Joaninha, o que aborrecia muito Adão (Depoimento de Tia Bê para Zuleica Dantas. Pereira, 1994, p. 54-55, grifos meus).

Podemos ver uma tensão entre duas concepções relativas à família: de um lado as noções de transmissão de direitos e do outro a de transmissão de obrigações. O litígio parte da introdução de categorias legais e jurídicas ${ }^{94}$ em um contexto que, em princípio, as vê como exógenas. Seu expediente surge em nome da validação de direitos de posse, e o terreiro enquanto "propriedade". Em depoimento à antropóloga Zuleica Dantas Pereira, no final dos anos 80, Pai Paulo exemplifica esse ponto: o "direito à terra" não garante a "posse dos santos". Se os santos estão "ocupando" o espaço físico de uma casa, isso imprime uma relação cuja complexidade fica subsumida, se acreditarmos que a garantia do terreno garantiria também os

\footnotetext{
${ }^{94}$ Como aponta Marylin Strathern, "Há uma particular aquisição ao se trazer à análise o pensamento jurídico. Trata-se de uma disciplina e uma prática que precisam lidar com diferentes tipos de relacionamentos. Afinal, na mitologia europeia, o direito é o lócus clássico de situações em que relações categóricas e interpessoais entram em confronto. Julgamentos nas cortes, apelações no terreno dos direitos humanos: o direito lida com pessoas em relação a categorias" (Strathern, 2012, p.11).
} 
santos, porque, veremos, estes têm "participação" na rede de decisões, eventos e possibilidades. É dizer, a concepção jurídica não é extensível ao universo dos orixás - ou, ao menos, quando essa extensão é feita, seus efeitos são bastante específicos:

Meu tio Zé Romão fez usucapião, depois que já estava ai por mais de vinte anos, mais ou menos em 50. Depois ele ajeitava tudo dando uma parte para os irmãos Guilherme, Mãezinha---Mas só que ele adoeceu- E quando ele morreu, chegou os filhos tomando conta de tudo, chegando ao ponto de discutir com meu pai (Malaquias)- Tio Zé Romão, quando foi para o hospital, quando ele pressentiu que ia morrer mesmo, chamou meu pai, deu a chave do quarto de santo a ele, e mandou ele tomar conta dos santo dele. Depois que ele morreu, meu pai ficou- Dai o pessoal foi incentivando Papai, quando viu foi discutindo com meu pai- Ai ele disse a meu pai que era o herdeiro, era o dono! Meu pai, até um pinto pra matar ai, tinha que pedir satisfação a ele- Ai meu pai, já com a idade de setenta e quatro anos, se abusou e veio emboraDisse o que bem quis e veio embora- Aqueles santos não têm dono não! Aqueles santo é pra todo mundo adorar- Ele não é dono dos santos não! Pode ser dono da terra, mas do santo não! Então, quando Tio Zé Romão morreu, meu pai assumiu, depois ficou por conta dos herdeiros-Foi quando assumiu Papai-Uma vez, estavam jogando para fazer o presente de Iemanjá, e a santa sem querer aceitar o presente- Ai Papai mandou Vicência, com Tia Mãezinha, falar com meu pai e dizer que Iemanjá queria que ele fizesse o presente. Ele chega ficou arrepiado de tanta emoção. Ele aceitou fazer. Depois de um tempo, quando meu pai fez as obrigações, e Iemanjá aceitou o presente, Papai mandou dizer a ele que ele mesmo ia fazer o presente. Aquilo tinha sido uma topada! Aquilo pra meu pai foi uma queda! A queda foi tão grande que, com quinze dias depois, ele teve uma trombose e faleceu ${ }^{95}$ [PBs1992] (Pereira, 1994, p.61, grifos meus)

Em tese, toma-se a família como unidade hierarquicamente organizada. Nessa armação conceitual, a família seria a base de laços entre indivíduos, lastreada em relações de solidariedade, erigindo uma rede parentes como uma unidade coesa. Ou seja, mera extensão da noção de "família nuclear" e seus derivados. No caso específico do candomblé, a interpretação é a de que essa coesão promoveria entre as pessoas um horizonte de relacionamentos estáveis, em que elas poderiam se apoiar frente ao universo cada vez mais desagregador da sociedade envolvente. Esse é o cerne da noção de família de santo como substitutiva da família consanguínea pela literatura do candomblé.

Frente a isso, nada poderia parecer mais distante para essa noção de "família" comum na literatura antropológica do que uma cisão gerada no seio de uma estrutura tão fortemente

\footnotetext{
${ }^{95}$ Arnaud Halloy recuperou o efeito traumático que essa decisão tomou na história da família: "Ela também observou um episódio após a saída do Pai de Santo, onde algum tempo depois que Malaquías deixou o Sítio, duas pessoas do Sítio vieram encontrá-lo para pedir sua presença no presente de Yemanjá, porque esta o reivindicou, através do oráculo. Uma semana depois, as mesmas pessoas vieram avisar que sua presença não era mais necessária. Todos os mágoados por essa segunda afronta atribuíram essa inversão da situação à 'vontade dos homens' e não à de Yemanjá Ogunté, de quem Malaquías talvez fosse o representante mais ilustre da época. Esse evento apenas aumentou a 'raiva, mas também o desgosto' de Malaquías e apenas contribuiu, segundo seus descendentes, para a 'degradação do Sítio'. 'Meu pai morreu de nojo', comentou Lucínha uma vez para encerrar uma conversa sobre esse episódio. Outra lembrança dolorosa ligada a Malaquías é a amputação de suas duas pernas que, como muitos de seus filhos, sofriam de hipertensão e diabetes" (Halloy, 2005, p. 136).
} 
estratificada como uma família de santo. Uma família de santo apoiada em laços consanguíneos funcionaria então como um duplo reforço a esse pressuposto: o contraste entre família de sangue e de santo teria como fundo nossas concepções de "poder" e o efeito das duas linhas de composição seria o da sobreposição. Sendo assim, a justificativa encontrada pelos analistas foi ancorada nas presunções de "disputa de poder" pela liderança que motivaram essa cisma dentro da busca dos indivíduos em acederem ao controle do terreiro para "legitimarem" suas posições hierárquicas e os benefícios que adviriam dessa posição de status: “[n]as duas famílias, sagrada e profana, se encontram o discurso da legitimação da sua posição dentro da hierarquia da família religiosa, através de sua reconstituição de parentesco, seja com pai Adão, seja com Tia Inês" (Pereira, 1994, p. 97).

Nessa perspectiva, as linhas de sangue e santo são tratadas de modo instrumental. Quando a tensão entre os dois pólos surge na análise como um problema, o analista necessita inserir um terceiro ponto para explicá-la. Nesse caso, com o propósito de unir as duas linhas para garantir a coesão do grupo e sua dita "legitimidade", a ascendência africana que ambas expressam serviriam como pretexto para garantir a continuidade do grupo, reforçando seu status. Esse é, por exemplo, o argumento de Beatriz Góes Dantas a respeito do nagô de Laranjeiras em Sergipe:

\footnotetext{
Desse modo, organizando-se internamente por princípios que privilegiam a ascendência africana reconhecida, a supostamente nagôs assume uma grande ou importância para os integrantes do terreiro. Através dela constitui-se o núcleo do grupo de culto aquele que será frequentemente invocado para atestar sua continuidade com a África (Dantas, 1988, p.90).
}

Não obstante, se mudássemos um pouco a perspectiva e se a análise não buscasse resolver a tensão entre os dois pólos pela adição de um terceiro termo externo; se nos ocupássemos das próprias elaborações e questões colocadas pelos praticantes do candomblé, em especial dos membros deste terreiro em questão, que efeito tal procedimento teria sobre o modo como percebemos o evento da disputa?

Esse é meu primeiro argumento. Ao contabilizar apenas um lado da liderança masculino ou feminino - como passível de disputas e litígios, perde-se uma característica importante das casas nagô, a de que um terreiro necessariamente possui um pai e uma mãe de santo. Essa característica tem de ser levada em conta em qualquer discussão sobre a herança de uma casa.

A resposta me parece vir do próprio material etnográfico dos trabalhos citados aqui. Zuleica Dantas Pereira percebeu que as disputas pela sucessão no Sítio não surgiram em relação 
apenas à parte masculina da liderança, mas também em torno da escolha do cargo de mãe de santo da casa. Embora as tensões para a sucessão masculina tenham alcançado maior evidência, sua contraparte também foi fruto de intensas e, por vezes, silenciosas disputas:

Depois que Vicência morreu, Papai jogou né? E segundo o jogo dele deu Bê. Eu não sei se foi bem interpretado, eu não estava lá- Tia Mãezinha estava lá, mas ela não é de dizer nem sim, nem não. Eu como gosto da justiça e do direito, se fosse eu que estivesse na frente do Sítio, a mãe de santo do Sítio era Tia Mãezinha, por causa da idade e do conhecimento dela. A velha conhece! Antes, a tradição era o mais velhoE talvez por desconhecimento da tradição é que ela foi quebrada

Pessoal de Malaquias não queria Bê. Mas o jogo disse que era ela. Foi jogo aberto nas folhas. Foi feito por mim na presença de quarenta pessoas antigas, com consulta feita a todos os presentes. Bê não estava presente- Deu três ossadé- Três oduns de Iemanjá, consultado disse que era ela e Ifá queria festa- Bê e Mãezinha se abraçaram - (PBs. 1992. Pereira, 1994, pp.63 e 64 ).

Como vemos nesses depoimentos, o jogo de búzios é o ponto de partida para se resolver (ou questionar) a questão da sucessão. O jogo de búzios em Recife, conforme descrito anteriormente, é geralmente consultado na modalidade de 16 búzios, conhecida por Erindilogum (Carvalho, 1984; Halloy, 2005; Filho, 2015). O jogo possui uma dinâmica própria de manuseio e obtenção de respostas relacionadas aos contextos de sua execução, que mediam a comunicação entre homens e orixás de maneiras distintas, manejando essas composições de acordo com seu próprio universo conceitual: a partir dos números de búzios abertos e fechados, obtém-se o $o d u$. São essas combinações que permitem o jogo transmitir ao consulente o recado dos orixás, que falariam por meio dos odus, pelas quais eles veriam o que estava ocorrendo. Essas "respostas" implicam, também, a execução de uma oferenda como modo de solucionar determinados problemas, como assinalou o pai de santo a respeito do resultado do jogo que entronizou a nova mãe de santo.

O “jogar” significa, então, a capacidade de se interpretar os recados e a eficácia de seus vereditos. É nesse ponto que há abertura para a divergência na análise do resultado da caída, o que implica, principalmente, na capacidade/necessidade de ser confirmado por outras pessoas ou técnicas de jogo. Realiza-se, assim, um constante movimento de "jogar" e "confirmar" dentro de uma técnica específica, e é ele que define o resultado. Essa confirmação é que garantiu que o orixá da casa, Iemanjá, havia aceitado a nova mãe de santo: "deu três ossadé - Três oduns de Iemanjá".

Outro ponto que garantiria a "boa sucessão" seria que pelo menos um dos líderes, ele ou ela, fossem filhos de Iemanjá Ogunté, a dona da casa. Era esse o orixá de Tia Inês, de Pai Adão e de Dona Joaninha. Era também o orixá de Malaquias e é o de sua filha, Mãe Lu. 
Esse era um dos pontos de divergência em relação ao santo de Manuel, enquanto filho de Iemanjá, como aponta Rita Segato:

Portanto, ter Iemanjá como dono da cabeça representa, indubitavelmente, um elemento positivo para quem quer que quisesse assumir a liderança daquela antiga casa de culto. De fato, tanto tio quanto sobrinho eram filhos de Iemanjá, e dois dos filhos do tio tinham também Iemanjá como dono da cabeça. Essa família foi a única que conheci no Recife na qual o fator genealógico tinha tal peso na escolha do santo. [...]. Nesse contexto, não é de assombrar que, como o mesmo informante me revelara, ele fora feito filho de Iemanjá a despeito de ser mais propriamente um filho de Obaluaiê. Obaluaiê foi, então, deixado para o segundo lugar. De acordo com seu depoimento, o famoso sacerdote baiano Joãozinho da Goméia, em sua visita ao Recife, uns vinte anos antes, perguntou a seu pai legitimo, filho de Pai Adão e pai de santo do Sítio à época, por que ele permitirá que seu filho fosse feito filho de Iemanjá embora fosse verdadeira e obviamente um filho de Obaluaiê. O sacerdote teria concordado com a crítica de Joãozinho ao tempo que se lamentava de que era já muito tarde para trocar o santo do filho, que já tinha passado pela iniciação. O motivo: 'foi para manter a tradição da casa' (Segato, 1995, p.251).

O fator genealógico apontado por Segato não deve ser lido como uma influência formal de um modelo de transmissão de direitos. O que minha etnografia aponta é que essa "influência" está mais para um "corte" na linha de descendentes consanguíneos. Como se vê, nem todos os descendentes de Pai Adão são passíveis de serem seus sucessores na liderança do Sítio. Ele próprio só conseguiu assumir a liderança, desse ponto de vista, por ser filho de Iemanjá Ogunté. Após a sua morte, ao menos um dos líderes da casa era filho desse orixá. José Romão era filho de Ogum, mas as suas contrapartes femininas eram filhas de Iemanjá. Malaquias era filho desse orixá, a exemplo do pai, mas nem todos os seus filhos eram filhos de Iemanjá, apenas sua filha mais nova, Lúcia, e seu filho, Paulo.

Esses cortes na linha de consanguinidade demonstram como a noção de sistema de linhagem com ênfase agnática ou cognática, no caso dos candomblés, não pode ser vista como um sistema de regras. Mãe Lu costuma afirmar que nem todos os descendentes de Pai Adão são ou eram "de dentro das coisas do culto". Muitos seguiram suas vidas sem uma participação mais ativa no mundo dos candomblés. E dos descendentes mais participativos, somente alguns eram filhos de Iemanjá. Para Mãe Lu, isso coloca alguns problemas na própria sucessão de sua casa, haja vista que, dentre suas filhas e netas, somente uma sobrinha-neta é desse orixá, e que no atual momento de minha pesquisa não era "muito de dentro das coisas do culto". Nesses casos, deve-se seguir a hierarquia, como dizia Pai Paulo, e "morrendo o pai ou a mãe de santo, quem assume é o mais velho no santo, que ficou".

Nesse ponto, o que se torna mais visível na continuidade de uma casa é o papel dos herdeiros legais da propriedade do imóvel, frequentemente parentes consanguíneos do pai ou 
da mãe de santo, quando há tal posse (grande parte dos terreiros funcionam em imóveis alugados ou de propriedade precária). Nesse caso, a linha que detém a responsabilidade pelo imóvel costuma ser alvo de intensas disputas, inclusive jurídicas, que por vezes impossibilitam a continuidade de um terreiro, como tratarei em um caso etnográficoabaixo.

No final da minha estadia em Recife, pude acompanhar um caso dramático de herança de uma casa que surgiu no seio de uma briga familiar. Um homem de 40 anos procurou Bino para jogar os búzios. O jogo apresentou um diagnóstico nada animador, com muitas caídas do odu Obiorossum, um odu que traz recados de morte e perseguições espirituais. Esse odu é por onde fala $O y a$, a dona dos eguns e o orixá de cabeça do desafortunado consulente. O rapaz disse que tinha perdido o emprego recentemente e que todos os aparelhos elétricos de sua casa haviam queimado na última chuva. Segundo ele, "um raio queimou tudo", pois “com Iansã é assim, ela cobra mesmo"; "fiquei sem um real, to só com a roupa do corpo". Bino agendou uma pequena obrigação, acarajés para Oya e um sacudimento.

No intervalo da obrigação, enquanto eram preparados os pratos do sacudimento, o rapaz nos contou sua história. De acordo com ele, Iansã estava cobrando sua cabeça há muito tempo. Ele era filho de santo de Roberto, pai de santo da casa de Dona das Dores, mas como esse pai de santo fora assassinado, não conseguiu pensar em mais ninguém para fazer seu santo. A situação se agravara com a morte de sua mãe carnal. Ela tinha em sua casa um peji, que cuidava com seu filho mais velho que, conta o irmão, "ajudava ela em tudo, era o axogum dela". Quando a mãe de santo faleceu, todos em sua casa tomavam como certo que seu filho mais velho continuaria cuidando e zelando dos santos da casa. Um engano, já que o rapaz, que até então sempre fora um responsável axogum, se converteu a uma igreja neopentecostal. "Talvez de desgosto pela morte de mainha...", especula o desafortunado cliente, que era o filho mais novo. "Um dia, quando passei na casa de mainha, meu irmão tinha jogado os santos fora e derrubado o peji”, contou ele a Bino, que acenou balançando a cabeça em sinal de desaprovação. O rapaz queixou-se de $O y a$ não ter cobrado seu irmão. Diz que não sabia que o irmão faria isso e que se soubesse teria ficado com os santos. Bino explicou que o santo cobrou do rapaz porque ele tinha Oya como santo de cabeça e que por isso a cobrança era mais forte. Assim, o jogo tinha dito que ele deveria assentar novamente a $O y a$ de sua mãe e fazer sua própria obrigação - era isso o que o orixá estava reclamando. Não soube do desenrolar da história. De todo modo, a disputa pela casa da família agora estava em outra esfera, a judicial, e a parte dos orixás estava decidida. 


\section{O CONFLITO ENQUANTO MOTIVAÇÃO DE FORÇAS}

Quando conflitos como esses inviabilizam o prosseguimento de uma casa, outros que compartilham a liderança de um terreiro podem "herdar" os santos e cultuá-los em outra casa. Outra possibilidade é a de algum membro da família consanguínea que tenha relação com o universo dos orixás ser convocado a assumir a direção da casa ou o cuidado com os orixás do falecido.

Retomando o caso da sucessão do Sitio de Pai Adão, gostaria de desenvolver um outro ponto que torna complexo o argumento de que seriam as linhas de sucessão que garantiriam a continuidade da autoridade da família consanguínea é o dispositivo ritual, nos terreiros nagôs de Recife, o impedimento para que pais e filhos carnais tornem-se pais e filhos de santo. Esse ponto incide na linha de sucessão e retoma a crítica ao argumento da herança legal ou formal da propriedade do Sítio como um direito dos herdeiros legais. Como já mostrei, no nagô, pais e mães de sangue não podem iniciar seus próprios filhos carnais. Nesse sentido, Manuel Papai não era filho de santo de seu pai José Romão. O que quero ressaltar aqui é como a linha do santo opera um corte na linha do sangue.

Sobre a ruptura do Sítio, embora essa cisão tenha efeitos drásticos na vida dos envolvidos naquele momento, o rompimento nunca foi definitivo, ainda que sua duração seja bastante notável. As pessoas continuaram e continuam participando da vida dos terreiros (do Sítio e do Ilê Iemanjá Ogunté) em maior ou menor grau de intensidade. Na geração dos descendentes da briga, o conflito adquire contornos e nuances que diminuem seus efeitos. Os filhos de Pai Paulo, por exemplo, são participantes ativos das obrigações no Sítio, tendo boa relação com Manuel Papai, a ponto de chamá-lo de "Tio". Mesmo os fillhos de Malaquias, à exceção de Mãe Lu, eventualmente participaram de algum toque ou obrigação na casa quando sob a liderança de Papai. Como justificativa, as pessoas sempre se remetem ao fato de que aquela casa também "nos pertence" e que seus orixás também são os deles porque fazem parte de sua família. A linha do santo, agora, produz um outro corte na linha de sangue.

Retornando ao diagrama de parentesco de Zuleica Dantas, veremos que tanto José Romão quanto Malaquias foram iniciados por outras pessoas, e não por Pai Adão. Ou seja, a linha de sucessão não é necessariamente determinada pela linha de consanguinidade, tal como sustentam esses autores (Pereira, 1994; Brandão \& Motta, 2002; Halloy, 2005). O argumento evocado por Pai Paulo em favor de Tia Mãezinha como mãe de santo do Sítio passa pela senioridade e não pela consanguinidade. Disso, é evidente que a consanguinidade possui um 
peso incontornável nessa disputa e ela pode, nesses casos, abrir a possibilidade para o próprio conflito, como podemos ver no depoimento dado por Manuel Papai à antropóloga Aída Ester

Bueno Sarduy, para o qual vale uma citação extensa:

Isso foi em uma semana do Carnaval. Naquele sábado de carnaval que discutimos, argumentei com a mulher dele e eles entraram na discussão quando a esposa disse que me odiava. Eu não sabia o porquê. Eu não havia lhe dado motivos para me odiar. Principalmente ele, a quem eu dei o lugar do meu pai quando meu pai morreu e para mim ele era meu pai. Não é fácil. Seus filhos, eles deixaram de ser meus primos e se tornaram irmãos e nós éramos unhas e carne. Onde você me encontrava, você encontrava o Paulo. Todos nós vivemos em uma união muito grande. Havia muita gente no Sítio naquele sábado de carnaval. Eu pedi a ela que me dissesse porque que ela me odiava e naquele momento ele estava chegando e perguntou o que estava acontecendo e eu disse a ele o que sua esposa havia dito. Naquela época, chamava de tia; Hoje não a chamo assim. Ele disse que não era exatamente assim. Se não era exatamente assim, então era mais ou menos assim, de acordo com minha concepção. Então, naquela época, tivemos uma discussão muito forte sobre a questão da herança; os filhos entraram[...] e essa guerra continua hoje. Eu já fiz tudo e não quero mais pessoas como testemunhas e sim Deus e os orixás, que eu já fiz tudo para que houvesse uma trégua, que houvesse paz. [...]

Sempre que ele tinha uma chance, ele estava gritando e isso estava chegando a um ponto em já não tinha limites. E ainda hoje não admito a presença de $P$, porque ele é uma pessoa muito arrogante, ele não deixa ninguém cantar candomblé. Só ele tem o direito de cantar, não há democracia para eles. Eles acreditam que meu avô era o mais velho, o melhor, e ninguém mais sabe nada e isso não é verdade. Eles também não admitem que existem outras nações em Pernambuco e esse também não é o caso. Eles são essas pessoas. Ainda hoje continuo com as portas abertas para quem quiser vir. Somente não aceito a presença de $\mathrm{P}$, mas mesmo assim, se ele entrar, não consigo tirálo. Você pode tirar alguém de uma igreja, a menos que tenha um comportamento que contradiga os princípios da religião; nesse caso, eu seria obrigado a tomar algumas providências, mas acho que não virá. A porta ainda está aberta para quando eles querem vir. Ao Sr. Malaquias eu sempre o ajudei, porque era ele que cortava na casa de minha mãe / Iyalorixá Dona das Dores. Como eu era o axogun da casa ajudava na matança. Fazíamos tudo juntos: o obori, tudo, não precisa nem falar. Eu o entendi bem, sabia e sabia quando queria cada coisa, quando ele não queria algo e qualquer coisa que estava faltando. Quando ele chegava já estava tudo pronto para a cerimônia, mas sempre pode faltar uma coisa ou outra, e se ele queria algo naquele momento e falava como se estivesse falando com as paredes: "Ah, seria bom se tivesse isso desse jeito"... Então eu já sabia que tinha que procurar por isso. Eu sempre deixava uma pessoa e a deixava para servir ele, porque ele sempre gostou, depois do candomblé, de beber um runzinho, uma cerveja.

Ele cantava o candomblé muito bem; ele foi o maior cantor de candomblé de Pernambuco e até hoje ninguém apareceu como ele. Ele tinha alguns pulmões que Deus lhes abençoe! Ele tinha uma voz alta que muitas pessoas, sabiam que ele ia cantar, vinham apenas ouvi-lo. Cantava muito. Outra coisa era a colocação da língua iorubá e também do Português. Era uma coisa incrível. Ele era um ótimo cantor e também dançou bastante e bem. Seu filho Paulo também dança, mas ele dançava muito mais. É assim ... Manoel do Nascimento Costa e Malaquias Felipe da Costa.

Ainda existe tudo isso hoje, mas isso é uma tradição do Sítio desde a época do meu Avô, parece-me. Desde então, essas brigas já existiam entre a família do meu avô e a família de Dona Joaninha, Joana Batista, que era madrinha do meu pai. Que foi por muitos anos a mãe de santo da casa.

Pergunta: E você não considera uma perda para o Sítio de Pai Adão ter perdido parcialmente a família do Sr. Malaquias? 
Não, pelo contrário, acho que há mais riqueza, porque essa parte da família, hoje eles fazem um trabalho muito bom, independente do Sítio. Então eu acho que se todo mundo ficasse trabalhando aqui, tudo ficaria aqui e se nos separássemos, nós enriquecemos aqui e ali. Quanto à família, acho que não perdemos muito pelo modo de ser deles. O Sítio chegou ao ponto de cair ... [...] Graças à Dona Beleza - Dona Iraci Vilela -, a Iyalorixá da casa, a casa levantou-se novamente... (Sarduy, 2014, p. 214).

Nessa fala de Manuel Papai, há duas coisas sobre as quais gostaria de me deter. Primeiro, na constatação de que essas brigas de família sempre estiveram de algum modo presentes ao longo da vida comunitária do Sítio. Poder-se-ia dizer, na perspectiva de alguns, que estaria previsto, já que muitas pessoas atribuem isso à influência do odu Ossatinukó, que elas costumam elaborar como "vem falando de muita briga, falsidade, desavenças". Tais desentendimentos têm acompanhado a história da casa.

O segundo ponto, e mais importante, é que para o pai de santo, esses desentendimentos e as segmentações eventualmente daí derivadas produzem mais "riqueza" para a família. De certo modo, as brigas de família, que muitas vezes produzem secções e separações em um terreiro, podem igualmente fazer proliferar outros terreiros que, por sua vez, darão continuidade, aos seus modos, para a tradição de uma casa. Dentro do Ilê Iemanjá Ogunté, algumas dessas "brigas de família" motivaram a criação de outras casas da linhagem de Malaquias. Contudo, não podemos associar esses conflitos como motivadores exclusivos da criação. Principalmente porque essas brigas produzem afastamentos e aproximações entre os membros da família de diferentes formas, e se algumas antecipam a criação de um terreiro, outras se desenrolam após anos do estabelecimento desses conflitos.

Sobre isso, José Jorge de Carvalho (1988) demonstra como esse aspecto agonístico da vida das pessoas do nagô em Recife não é apenas fruto de uma disputa por sucessão ou mesmo originado do lugar de autoridade dos religiosos, mas um elemento cotidiano da vida nos terreiros, cuja dimensão não deve ser reduzida na análise apenas à política. Seja entre terreiros, entre integrantes de um mesmo terreiro ou de uma mesma família, fato é que "há uma dimensão dos cultos em Recife que é ineludivelmente a dimensão dos conflitos interpessoais, das intrigas no interior das casas e entre casas diversas. Essas intrigas são, a meu ver, parte e parcela da experiência religiosa". Trata-se não somente de um aspecto generalizado do cotidiano religioso de uma casa, mas principalmente do fato de que:

na concepção dos membros são os ancestrais, os grandes líderes do passado e que de fato prestavam; os vivos, estão quase todos imersos numa rede infindável de confrontos, despeitas e desavenças. E não só a qualidade dos humanos sói ser diminuída - encontra-se defeito também em inúmeros seres espirituais. Além, obviamente, das vitorias e graças alcançadas, também o fracasso e o retrocesso na vida, desde que entendidos como expressão da vontade divina, atestam a 
principal promessa de felicidade que da o Xangô: a presença e o convívio direto da pessoa com o seu santo (Carvalho, 1988, p.7, grifos meus).

Essa dimensão também foi percebida por Arnaud Halloy (2005, p. 649), que descreveu como os orixás interferem regularmente no cotidiano de seus filhos. Dessa interação, ele abduz dois pólos com os quais as pessoas se confrontariam, o da "fraternidade" e o da "discórdia". Enquanto o primeiro seria um ideal a ser buscado, o segundo seria um obstáculo contra o qual se deveria lutar. Nesse sentido, a "irmandade" se manifestaria no desenvolvimento de diferentes formas de "ajuda mútua" dentro do terreiro, seja pela participação comum nas mesmas atividades rituais e festivas, seja no compartilhamento de uma experiência semelhante de interação com as divindades. O polo da discórdia possuiria dois modos de enunciação, o aspecto mais "oculto" (mau olhado, acusações de bruxaria) e um modo mais ostensivo (das acusações públicas e conflitos explícitos e barulhentos). Segundo Halloy, "cada uma dessas formas, de acordo com seu próprio mecanismo psicossocial, atinge o indivíduo em seu equilíbrio físico, psicológico ou social, ou o grupo em sua coesão interna ou em suas relações com o exterior" (idem, p. 683).

De acordo com o autor, a maioria dos pesquisadores reforçaria o polo da fraternidade, produzindo uma visão "romântica" e "idealizada" dos terreiros. Em suas análises, a solidariedade se conformaria como uma herança estrutural-funcionalista da determinação dos grupos. Em sua análise, a solidariedade se conformaria como uma herança estruturalfuncionalista da determinação dos grupos, que teriam como exemplo, segundo ele, as noções bastidianas de "princípio do corte" e "cerco cultural". Halloy diz ainda que os estudos oriundos dos anos setenta destacaram, por sua vez, o polo oposto, evidenciando os "conflitos", as "lutas pelo poder", estas tidas como características da vida nos candomblés $(2005$, p. 660).

Às conclusões de Halloy, eu faria algumas ressalvas. Uma primeira é extraída do próprio material do autor, donde, como bem apontado, a desunião e discórdia são entendidas tanto como um efeito de mau-olhado, fofocas, ação de bruxarias advindas de espíritos de esquerda, da "fumaça", e do uso desses como instrumentos de ação posteriores a um desafeto, quanto se situam ao mesmo nível de ações nefastas que esse tipo de instrumento ritual produz ${ }^{96}$. Inúmeras vezes presenciei, a partir da leitura do jogo de búzios, tanto orixás quanto eguns tomarem parte nessas brigas e confusões. Em alguns casos, até mesmo a incorporação de uma entidade que

\footnotetext{
${ }^{96}$ Como apontou Edgar Barbosa (2014, p.10): “A minha experiência de campo me leva a pensar que os conflitos mais graves, aqueles que podem efetivamente conduzi-las a gravíssimas e perigosas 'guerras de feitiçaria', acontecem quando a proximidade é maior, seja ela estabelecida pelo parentesco ou pelo território”. .
} 
alertara sobre o tema da fofoca ou sobre como o que era dito por determinada pessoa (estando ela presente) contribuía para as confusões. De tal modo, não é possível afirmar que a fofoca seja uma dimensão apenas oculta e não pública desses desentendimentos.

Outro modo de participação não humana ativa nos conflitos eram os recados dos orixás ou dos eguns quando estes se desagradam por alguma briga ou desentendimento. Ao início e ao fim de qualquer cerimônia, o jogo de búzios é sempre consultado para saber se as obrigações foram bem aceitas e se as divindades estão de acordo. Nas situações em que uma briga ou confusão tinha se desenrolado recentemente e o resultado do jogo vinha negativo ou topando (quando uma sucessiva de quedas negativas acontece antes de uma positiva aparecer), a pessoa que conduzia o jogo alertava os presentes que os orixás estavam em desagrado com as esculhambações entre os familiares de um terreiro. Outro modo de participação são também os recados por intermédio dos sonhos, quando uma pessoa sonha com algum parente falecido ou orixá descontente com a participação dela ou de terceiros nesses conflitos.

Há, nesses casos, o risco de que a divindade ou entidade espiritual se afaste da pessoa, deixando de protegê-la ou cuidar dela devido a tais desentendimentos. Paulinho, ao comentar comigo uma dessas brigas frequentes, disse:

"Meu medo é de Iemanjá ir embora, cansar dessas brigas e não vir mais. Eu sou pelos orixás, para cuidar dos santos de meu avô, continuar o que ele deixou. Se não fosse isso, eu já tinha largado de mão há muito tempo. O que é status? É aquilo que a gente leva pro caixão."

As pessoas não explicam esse tipo de situação apenas pela ação espiritual, mas também apontam para a dimensão da personalidade das pessoas, tal qual conclui Junior de Oguian: "Por que dar 'comida' ao 'Exu da Rua', fazer todo o 'preceito' se a anarquia vem de dentro?" (Halloy, 2005, p. 678).

Essa noção de personalidade, ou temperamento, seria elaborada pelos membros da família também a partir de sua hereditariedade, ou seja, as pessoas da família são conhecidas por seu domínio ritual, pela beleza de seu canto, pela habilidade técnica em tocar os instrumentos. Alguns são conhecidos também pelo seu temperamento, por "dizerem o que pensam", por "dar bále" 97 . Essa característica é sempre evocada pelas heranças: "faço como meu pai fazia", "meu tio não levava desaforo, o que ele tinha de dizer ele dizia na hora". Pai

\footnotetext{
97 “Dar bále” quer dizer fazer confusão, "barraco”.
} 
Paulo dizia que seu avô Adão era "arrogante mesmo, [que] o velho sabia das coisas"98. Como notou Halloy (2005, p. 683), essas são características tanto do conhecimento quanto da relação com os orixás. "Tal atitude deve ser comparada, como sugeri, à afirmação de seus membros de uma 'natureza' diferente, que apareceria na expressão de um excedente incontrolável de força, o que testemunharia uma 'forte descendência' e uma maior proximidade com os orixás".

$\mathrm{Na}$ esteira do argumento de Halloy, entendo que mais daquilo que ele nomeia de "força de caráter" poderia ser invertido e compreendido como "caráter enquanto força". Desse modo, não é possível estabelecer nem a "solidariedade", tampouco a "discórdia" como polos pelos quais se desenrolam os relacionamentos. Elas atuariam na vida das pessoas também como “forças". Ou seja, antes de ser apenas uma dimensão da relação entre humanos ou da disposição destes em seu cotidiano, essa dimensão dos relacionamentos é sempre mediada pela ação dos orixás e eguns, sendo entendidas como a ação direta destes no cotidiano de uma casa de santo.

Pai Paulo se referia às brigas e aos desentendimentos como infortúnios, a depender do resultado de uma caída do jogo de búzios. Nesse caso havia sempre alguma oferenda ou ação ritual visando a tirar da pessoa esse aspecto negativo que a estava atrapalhando. Desse modo, a "solidariedade" também não está garantida pelo simples fato de as pessoas participarem de uma mesma casa e, mais ainda, de uma mesma família. Muitos são os pedidos nas obrigações e invocações para que os orixás e eguns tragam para a vida das pessoas paz, tranquilidade e harmonia. Esses eram temas recorrentes dos escritos de Pai Paulo sobre Ifá. Trago como exemplo um recado do jogo posterior à festa de Iemanjá de 2013, na qual aconteceu uma briga em decorrência de uma foto que alguém tirou de Iemanjá e "ela não gostou”. Ainda não havia chegado a Recife quando essa festa ocorreu, mas desde os primeiros dias em que estive na casa de Mãe Lu, o evento era motivo de conversas. Cada um interpretava o ocorrido de uma forma diferente e Pai Paulo receava que as conversas e atritos saíssem do âmbito reservado da família e chegassem a discussões acaloradas em sites de relacionamento. Esses eventos deixaram Pai Paulo bastante apreensivo, uma vez que ele temia pelo "nome da família" com o risco de serem tornadas públicas aquelas informações. Sobre isso, aconselhou Ifá:

\footnotetext{
${ }^{98}$ Halloy e Carvalho mencionam inúmeras narrativas a respeito dessa característica de Pai Adão. Em Xângos do Nordeste (1937), Gonçalves Fernandes descreve Adão, dizendo que, de fato, era conhecido por seu "porto de grande chefe", mas também por sua "arrogância", o que o levou a criticar severamente os outros líderes de culto e a "tratar como iguais" os médicos do Serviço de Higiene Mental (Fernandes, 1937, p. 56-58). Em uma sociedade racista, de escravidão recente, podemos nos indagar sobre o que significaria, para um branco, um pai de santo negro tratá-lo como igual.
} 
RECADO DE IFÁ HOJE 24.12.2013

Olofin Odudua criou Ifá para conservar este grupo étnico fundado por ele para todas as divindades, com dignidades e muitos respeitos. Eró, foi designado para saber através das consultas se os adeptos ainda estão seguindo os mesmos fundamentos iniciais; Oba Afinulode, traduzindo o recado, falou que tudo está modificado. Ao iniciar as oferendas, já estão procurando saber quantos dias ficarão de resguardo. Não procuram saber qual a oferenda, se é ebó ou adimu sacrifício; $O$ que ofertar as divindades; Ou a quem ofertar. Muitas vezes, o Orixá só quer água, e lhe oferecem um boi. A oferenda não deu certo porque não lhe deram a água e a oferenda não foi aceita, porque lhe deram um boi que ele não queria. A adoração está sendo feita mais em função do dinheiro do que do amor ao Orixá; Brigas, esculhambações entre familiares, atos amorosos entre sexo do mesmo sexo, Ifá não está com preconceito, só está falando dos desrespeitos às divindades. Dificilmente, cantam-se Caruani, que é para ganhar tempo para sacrificar o próximo, quando o animal anterior ainda está se debatendo. As boas sortes vêm trazendo um dia vitorioso, com alegrias de poder ter filho ou mais, Terá uma situação financeira controlada; $E$ na velhice, deverá existir no casamento mais compreensão entre o casal, evitando pequenos atritos entre o casal, evitando pequenos atritos, para alegrias e felicidades nas relações amorosas.

A partir do que foi exposto, cabe perguntar: o que devemos levar em conta em contextos de disputa e conflito em um terreiro de candomblé? Levar em conta os "interesses" e "disputas" por "prestígio" e "poder" - que eventualmente podem participar das redes de motivações de um conflito - parece ser um problema na medida em que reduz todas as dimensões de um evento excluindo outros motivos, demais agentes e efeitos diversos. Devem-se expandir os aspectos de conflito e solidariedade, notadamente seu caráter eminentemente político, e atentar para os diferentes regimes de participação que eles produzem.

Marcio Goldman (2016) traz uma importante crítica sobre esse aspecto ao descrever um evento ocorrido no terreiro Matamba Tombency Neto, em Ilhéus, que poderíamos circunscrever ao domínio dos conflitos dentro dos terreiros:

E, de fato, como o desenrolar os fatos me lembrou o mais direto possível, que um terreiro de candomblé não é um espaço político no sentido em que os gregos inventaram essa noção. Ou seja, não é um espaço exclusivamente humano, em que 
seres supostamente racionais se enfrentam. Um terreiro está cheio de outros seres e outras forças envolvidas, embora o antropólogo não o queira. Pois bem, assim como, ao definir o espaço político, os gregos não apenas excluíram mulheres, crianças, escravos e estrangeiros, mas também as forças naturais e seres sobrenaturais, penso, delimitando o campo de suas investigações e de explicações, a antropologia excluiu boa parte do que constitui o mundo para a maioria dos povos que estuda (Goldman, 2016, p. 32).

Podemos então retornar ao argumento de Arnaud Halloy, ao trazer sua crítica a determinado efeito das teorias de Roger Bastide nos estudos sobre o Candomblé. Voltemos às elaborações de Roger Bastide, quando propôs não circunscrever as relações àquilo que pensamos enquanto registro da vida social. Em lugar disso, deve-se pensar que qualquer elaboração sobre esse social deve implicar o modo como os praticantes do candomblé pensam e refletem o que constitui esse plano:

De qualquer modo, porém, o social nada mais faz do que inscrever, no domínio das relações interpessoais, as leis da vida mística. Os graus de participação ao grupo nada mais fazem do que seguir os da participação do homem ao seu Orixá. As variações da solidariedade social não são enfim mais do que o reflexo e a consequência das variações da solidariedade estabelecida entre a pessoa e o mundo dos deuses. Eis porque a posição do fiel na seita muda de acôrdo com a fôrça do vínculo que o une a ela [...]. Por fim, a coerência da sociedade religiosa, das formas e dos processos de relação entre os membros dela, a participação maior ou menor dêstes membros ao tesouro de representações coletivas, os tipos de cooperação, dependem, em última análise, das ligações religiosas preestabelecidas entre os candidatos à vida do candomblé e as divindades (Bastide, 2001, p 38, meus grifos.).

As relações pessoais - nas quais normalmente se enxergam relações de poder e disputa - estão permeadas, inevitavelmente em um contexto religioso de terreiro, pelas relações divinas. Se tirarmos essa afirmação do registro das formas - uma forma social, uma forma mística - e passarmos ao registro das forças, o efeito disso poderia redesenhar o modo como nos habituamos a descrevê-las.

\section{HERANÇA DOS SANTOS}

Como foi discutido na introdução, os primeiros debates sobre a família de santo assumiam o dualismo entre a religião da linhagem familiar e a religião da comunidade, esta tida como expressão dos cultos às divindades no oeste africano (ver Herskovitz, 1954; Bastide, 1958; Lima, 1977). Os autores argumentavam que no Brasil se daria a separação entre o culto familiar das divindades e sua reconstrução em famílias rituais. A noção de família levou adiante essa premissa dualista de laços familiares e laços ritualísticos, ganhando ainda um outro 
contorno binário atinente às dimensões mais internas do culto (rito, por exemplo) e expressões religiosas de maior alcance.

$\mathrm{Na}$ primeira seção deste capítulo, a partir das narrativas de brigas e conflitos que envolvem, principalmente (mas não apenas), a sucessão, demonstrei como a noção de descendência consanguínea e de santo entre os membros do terreiro indica uma "hierarquia de forças" que compõe sua relação com os orixás. Na segunda etapa do capítulo, a partir da noção de heranças espirituais, demonstrarei como as pessoas e as divindades são compostas por essas linhas de transmissão de dons, santos e sangue.

No trabalho de Beatriz Góes Dantas (1982), encontramos um contexto similar ao que encontrei em Recife, envolvendo o conceito de herança dos santos na relação entre "família biológica" e "família de santo". Dantas nota que em Laranjeiras existiam inúmeros casos nos quais os "santos" são herdados e reencontra o dualismo ao associar o culto doméstico dos orixás em contraste com os terreiros estabelecidos. De acordo com a etnografia da autora, o culto doméstico dos orixás estaria associado aos descendentes de africanos que receberam esses cultos como herança de seus ancestrais, "os santos da costa". Essa devoção seria transmitida por "linhagem", ou seja, para as famílias negras de Laranjeiras seria, portanto, uma herança de parentes de sangue.

Essa pessoa pode dar prosseguimento ao cuidado dos santos ou entregá-los para serem cuidados em algum terreiro. São esses os "santos de herança". Beatriz Góes Dantas relata algo similar em Laranjeiras, como atesta o depoimento da mãe de santo Dona Bilina:

Ja nasci pra ser dona das colônias de Santa Barbara pela África. Quando se acabasse os africanos eu era a dona. Quando eu era pequena eles botava eu na cabeça dentro dum cesto e sai dançando na roda. Isto era lá na casa de Ti Herculano, que o terreiro era lá. Eu nao me lembro mais. Eu era pequena. Vovó era quem contava.

Ti Herculano era um nagô, mas o primeiro beg ${ }^{99}$, o fundador mesmo do terreiro dos nago aqui de Larangeiras, foi Ti Henrique. De Ti Henrique passou pra Herculano, e dele pra eu. Quer dizer que eu não sou africana, sou neta. Neta de quatro avô africano nagô. Sou crioula legítima.

Ti Henrique, o primeiro beg*, eu não alcancei. Ele era malungo* da minha avó. Ele fundou o terreiro na rua do Cangaleixo. Primeiro era lá. Que até vovó morou trinta e cinco anos com a mulher dele. Vovó era escrava no Tanque da Moura (fazenda) e depois ficou viúva e veio s 'embora pra Larangeiras, e morou la. Que quando Ti Henrique morreu, o terreiro ficou pra Ti Herculano, que mudou ele pra Comendaroba.

\footnotetext{
${ }^{99}$ Como se nomeia o líder nessa nação.
} 
Agora os santos de Ti Henrique ficou na casa da rua do Cangaleixo. A viúva, a finada Caetana, era quem zelava junto com a minha avó. Depois que ela morreu, a filha Judite tomou conta dos santos que era da família, mas o terreiro ficou pra Ti Herculano. Eu não alcancei Ti Henrique, Agora Ti Herculano eu alcancei. Era um africano de muita ciência. Um nago grande e forte que morava la na Comendaroba. A casa era bem grande e ficava no meio de um sítio. Era gente de posse. Tinha salina, criava muito porco. A gente dançava era dentro da casa. Tinha um salão enorme. Cabia todo mundo. E nesse tempo tinha era muito filho de santo. Tinha ainda africano. Eu alcancei: Tia Lucinda, Inã pela África; Rufino um nagô que morava na baixa do Calumbi; Ti Oxo. Tinha muito, é porque eu não me lembro. Depois que festejava lá, que fazia o "corte do inhamé" daí ia festejava nessas casa todas. Ia pra Biachuelo, pra Socorro, Divina Pastora /cidades vizinhas/ que lá também tinha nagô que tinha santo, e Ti Herculano era quem festejava. Nos ia tudo. No Riachuelo era Tia Lucrécia no Socorro Tia Luiza. Era muito trabalho. Hoje que se acabou tudo, so restou nós. Eu brinquei múito na casa de Ti Herculano. Depois saí pra trabalhar. pra me empregar e quando voltei foi pra tomar conta desse lugar. Que esse lugar ficou pra mim e pra Manaia, que era filho, filho não, era neto de Ti Henrique. Ele num quiz, eu fiquei só. Que ate que ele não queria mais cuidar dos santo do avo, eu trouxe eles pra ca pro terreiro. Que quando é tempo de festejá eles ajudam, dão dinheiro, mas quem zela sou eu. Ta tudo aí no pege, os santos de Ti Henrique, o primeiro beg*. São santos legítimos africanos e muito fortes (Dantas, 1982, p. 44-45).

Figura 5 -Genealogia Parcial dos Chefes do terreiro nagô (Dantas, 1982, p.45). 


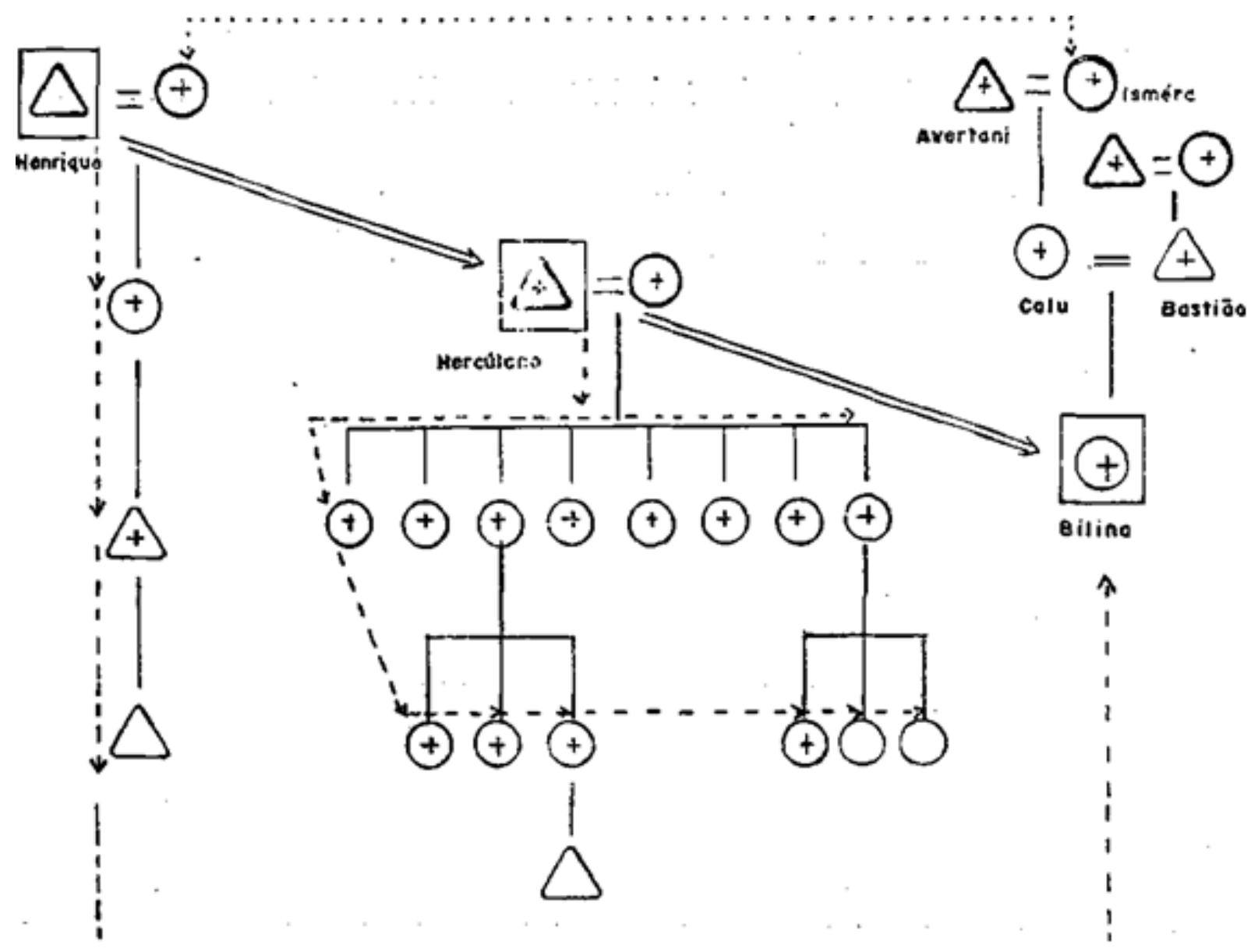

Figura 6 - Genealogia Parcial dos Chefes do terreiro nagô. (Dantas, 1982, p.45)

CONVENÇÕES

$\begin{array}{ll}\text { O } & \text { MULHER } \\ 6 & \text { HOMEM } \\ & \text { CASAMENTO } \\ 1 & \text { FILIAÇ̃̃o }\end{array}$

IRMÃOS

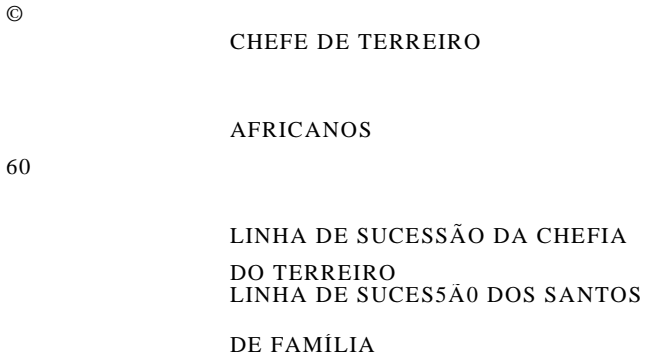

RELAÇÃO DE CONVIVÊNCIA 
Dantas relata que os assentamentos de santo seriam herdados por linhas diretas de relacionamento sanguíneo: mãe - filha - neta. O próprio terreiro de Mãe Bilina, principal interlocutora na época de sua pesquisa e mãe de santo de um dos terreiros mais antigos de Laranjeiras, teria inúmeros santos que foram herdados ou simplesmente deixados no terreiro para que fossem cuidados.

Ela, por quase meio século como chefe do terreiro, realizou muitas atividades atendendo a santuários domésticos. No decorrer dos anos, ele colecionou muitos desses "santos", que ela atualmente mantém em uma casa especial, que foi construída como abrigo dos santos de muitos proprietários, cujos herdeiros, por um motivo ou outro, os colocaram sob sua proteção. Ela diz que os recebeu sob sua proteção para impedir que os "santos da costa" fossem descuidados. A líder do terreiro é considerada guardiã dos "santos", mas ao mesmo tempo expressa claramente que a obrigação de cuidar deles e venerar, ou pelo menos fornecer os recursos para esse fim, são dos herdeiros, filhos e netos dos antigos donos dos santos. Portanto, é um problema que afeta parentes de sangue, popularmente chamados de "parentes de sangue" (Dantas, 1982, p. 148, grifos meus).

O debate sobre a noção de "herança" pode, em uma determinada leitura antropológica, aparecer sob a forma de predestinação que, nos argumentos de alguns autores, seria um recurso utilizado por determinadas pessoas nos intricados processos de sucessão e ascensão dentro da hierarquia religiosa dos terreiros. Considero essa interpretação derivada de duas condições: a primeira diz respeito ao interesse desses autores de objetivarem em suas perspectivas teóricas noções como "poder" como um conteúdo de constante disputa interna a um campo religioso; isso pode ter motivado o segundo ponto, que seria o uso de falas de religiosos, em geral dos líderes desses terreiros, em uma espécie de recursividade conceitual sobre o assunto, uma tautologia etnográfica. O que transparece nesses argumentos é que as heranças espirituais garantiram aos detentores uma espécie de controle da ascensão sobre outros filhos de santo de um mesmo terreiro e uma autoridade que emanaria dessa condição (Brandão \& Motta, 2002; Dantas, 1982, 1998; Boyer, 1996; Pereira, 1988, entre outros). É esse, por exemplo, o argumento de Góes Dantas, ao analisar a descrição à qual faço referência no início desta seção. Segundo a autora:

A mãe de santo, que teria tido acesso à chefia do grupo de culto por predestinação, aumenta sua força e prestígio perante o segmento afro-brasileiro local ao recolher os santos de família do fundador do terreiro - santos legítimo \& africanos e muito fortes e assim mais vínculos estabelece com a África (Dantas, 1982, p. 56). 
Não obstante, acredito haver uma dimensão central para as pessoas portadoras desse dom e ocultada pelas abordagens mais recorrentes: o caráter compulsório das obrigações e responsabilidades envolvidas nessas relações e nessas posições. Nesse sentido, a noção de "herança" é central nessa discussão, uma vez que pode ser entendida como mais um vetor na composição das famílias de santo. Primeiro, como aponta o conceito de obrigação ${ }^{100}$, essa predestinação, ou dom, adquire um caráter compulsório e traz uma série de implicações para as pessoas que a carrega. Uma das consequências dessa relação é expressa pelo termo "vontade": respeitar a vontade dos orixás, dos espíritos da Jurema e da própria pessoa. Porém, nem sempre é possível ajustar esses diferentes afectos, conforme demonstram os casos etnográficos a seguir.

Como vimos nos capítulos anteriores, entre as famílias de santo, existem inúmeros assentamentos herdados e seus orixás podem assim continuar na família através das gerações. Vimos também que, após o falecimento de uma pessoa, seus assentamentos são recolhidos ao balé, de onde só saem após o axexê. Nesse momento, é revelado se o orixá deseja continuar com alguém da família ou ser despachado com outros itens da pessoa que faleceu.

É comum aos orixás que desejam permanecer sendo cultuados determinarem quem, dentre os descendentes de santo ou de sangue, ficará responsável pelas obrigações anuais. Quando morre um pai ou uma mãe de santo, seus orixás individuais podem vir a ser cultuados como orixás da casa e todos de sua família de santo têm o dever de cultuá-lo anualmente. Outras pessoas podem, ainda em vida, determinar quem ficará responsável pelo assentamento de seu orixá na ocasião de seu falecimento.

Tomemos como exemplo o peji do Ilê Iemanjá Ogunté, onde grande parte dos assentamentos da casa são de orixás que pertenceram aos ancestrais da família. Paulinho, por exemplo, herdou de sua avó Leônidas o assentamento de sua Oxum, que mesmo sendo um orixá da casa foi confiado a seus cuidados.

Em geral, os assentamentos de uma pessoa tendem a ser destinados a membros de sua família consanguínea. Mas, em muitos casos, os santos podem ficar com uma pessoa da família de santo, e há ainda aqueles que desejam "seguir com seu filho". Em um dos axexês que acompanhei ao longo de minha pesquisa de campo, o santo principal da recém-falecida decidiu acompanhar a filha e ser despachado com seus pertences ao mar. Mãe Lu, na ocasião, me disse:

100 Como apontou Bastide (1958, p.30), o dom (direito a esta ou àquela honraria) exige o contradom (utilizar a honraria em benefício da coletividade), e isto de maneira tão necessária e automática que não se sabe qual considerar primeiro, se o privilégio ou a obrigação. Na realidade, trata-se do verso e reverso da mesma realidade. 
"Veja você como Iemanjá é mãe, ela acompanhou sua filha, quis ir com ela. Os filhos de Iemanjá são assim, quando eles se magoam com uma coisa, nada os faz perdoar. Ela não quis deixar o santo dela com ninguém da família, deve ter ficado magoada com alguma coisa."

Entretanto, caso não haja entre os familiares alguém que queira assumir essa responsabilidade, os assentamentos podem ser destinados a algum filho de santo. Esse foi o caso dos orixás Isaura, uma antiga e conhecida mãe de santo. Seu Xangô Aduban era famoso por ser muito "guloso", comendo dois ou três carneiros em cada obrigação. Mãe Lu se recorda que, apesar da mãe de santo ser uma pessoa bem "baixinha", quando "manifestada" em seu orixá, chegava a montar os enormes carneiros que eram destinados a ele, bem como ingeria grandes quantidades de beguiri "bem quente", feitos com centenas e até milhares de quiabos. Isso fez com que Pai Paulo, que fora escolhido para ficar com seu assentamento, ficasse receoso de não conseguir "sustentar" seu apetite voraz.

Outro caso muito comentado pelas pessoas da família de santo foi o de um antigo filho de santo que falecera recentemente e seu orixá decidiu permanecer na família. Sua esposa não poderia se incumbir desta tarefa pelas restrições rituais que recaem sobre os parceiros sexuais. O jogo então determinou que o orixá desse senhor ficasse sob a guarda de um de seus netos. $\mathrm{O}$ pai de santo que conduzia as cerimônias saiu do balé com o jogo de búzios, caminhou até o salão onde os familiares e as mulheres aguardavam e pediu que a criança jogasse com suas próprias mãos os búzios. O odu confirmou a vontade do santo nas mãos do menino, que chorou de emoção como a maior parte dos seus familiares. O pai de santo então se incumbiu de zelar por aquele orixá até que o menino alcançasse a idade e condições para fazê-lo, mas alertou: "somente depois da feitura ele [o menino] pode zelar pelo santo, pois para cuidar de um santo a pessoa também tem que ser preparada!".

De certo modo, aquilo que se herda implica em uma série de obrigações para as pessoas que recebem a determinação de continuar zelando por um orixá. É como me disse sorrindo um jovem filho de santo: "atualmente eu só ando na parte dos débitos e dívidas, tudo com juros, o dividendo anda pouco!". Contudo, a preocupação com a manutenção desses elos não pode ser reduzida às nossas concepções financeiras. Ela atenta aos modos com os quais esses vínculos não estão garantidos apenas com a revelação ou constatação desses elos, mas são fruto de intensa atividade ritual. Uma pessoa pode escolher não assumir essas obrigações, mas corre o risco de sofrer sanções por parte dos orixás, sanções estas que podem afligir até mesmo seus descendentes. 
Situação parecida foi descrita por Mirian Rabelo (2014, p.56) em seu trabalho com terreiros de Salvador. A autora constata a correlação entre as ideias de obrigação e herança, o que revela como "a afinidade com o candomblé e com os orixás não é simplesmente uma característica da pessoa singular, mas um traço de sua família que a distingue e singulariza enquanto portadora de uma obrigação herdada"idem. A autora diz ainda:

\begin{abstract}
Na história de alguns adeptos, esta experiência de retorno (de retomar uma herança e assumir o que sempre foi) tem que ser cuidadosamente construída ao interior do terreiro. Não encontra muitos ecos em outros domínios de suas vidas. Na história de Detinha - e dos outros 31 filhos de santo cujas vidas foram rapidamente apresentadas aqui -, ela tem raízes no mundo vivido. Afinal, eles conviveram e cresceram com a presença de orixás e caboclos e acompanharam diretamente os efeitos desta presença na vida de familiares mais velhos. Para eles, ancestralidade faz sentido como obrigação herdada. E os vínculos com as entidades já haviam ecoado em suas histórias e em seus corpos antes de serem selados com a iniciação (Rabelo, 2014, p. 77).
\end{abstract}

De acordo com os interlocutores de Rabelo, a entidade que de certo modo aflige a pessoa e da qual ela deve cuidar é uma entidade herdada, presente na história de seus ascendentes diretos ou colaterais. O cuidado que uma pessoa deve ter com essas entidades serve para atenuar, ou até mesmo compensar, uma negligência do passado, como explica um jovem filho de santo para a autora:

Você tem como missão no candomblé dar um determinado tipo de assistência aos
orixás, como auxílio, ou mesmo recebendo a manifestação do orixá, e se você nasce
com essa missão e se você não cumpre, não quer dizer que acaba. Isso que você não
cuidou no seu tempo de vida, vai repercutir lá na frente nos seus netos, nos seus
bisnetos, nos seus sobrinhos, na sua família, enfim, isso vai repercutir de alguma
maneira. E é isso que nós no candomblé chamaremos de herança que você herdar dos
seus mais velhos e que alguém na sua família vai ter que assumir isso. Então a minha
família veio ao longo do tempo trazendo essa herança que era passada dos mais velhos
aos mais novos (Rabelo, 2014, p. 68).

Em Recife, pode acontecer também de alguém herdar os assentamentos principais de uma casa que encerre suas atividades enquanto um terreiro. Quando morre uma pessoa que mantinha um terreiro e que por ventura não se encontre, entre seus descendentes, ninguém que queira ou possa assumir as obrigações da casa, ou ainda quando se julga não haver possibilidades de seguir com seu funcionamento - seja por alguma questão relativa à herança da propriedade do imóvel, disputa entre os herdeiros consanguíneos do proprietário da casa ou determinação dos próprios orixás -, nesses casos o terreiro fecha suas portas. Grandes terreiros do passado viveram seu declínio em decorrência de situações e eventos como os acima descritos, o que acarretou em sua extinção. Contudo, mesmo com o fechamento das casas, 
alguns de seus assentamentos permanecem sendo cultuados e cuidados por pessoas que ainda zelam por esses orixás.

Uma dessas casas é a das "Tias do Pátio do Terço", um terreiro de grande importância na história do nagô pernambucano, que vivenciou seu esplendor e ocaso por pouco mais de 100 anos de funcionamento. Esse terreiro foi fundado pela comunidade de africanos que residia no bairro de São José, região central da cidade, mais especificamente na rua Vidal de Negreiros, 143. Os eguns fundadores dessa casa, Ato e Aro, pais das tias, são sempre referenciados nas obrigações do balé das principais casas nagô do Recife. Sobre esse período de existência da Casa das Tias, Pai Paulo dizia:

"Meu avô dizia que os eguns mais fortes de Pernambuco eram Ato e Aro. Quando estavam zangados davam nas pernas da pessoa. Elas levavam chibatadas dos invisíveis. Ninguém sabia de onde vinham as varetas ou "inchans". Tia Eugenia, "Iaia", e outros iam para festa no Clube Vassourinhas, do qual eram fundadoras, sem ter ordem para sair de casa e eram castigadas. Elas chamavam meu avô para acalmá-los. Muitas vezes elas deixavam a criança na cama e a encontravam na rede levada pelos eguns que batiam nas pessoas por sair sem permissão. ",

Por muitos anos, a casa foi governada por duas africanas, Sinhá e Yaya, as "Tias" Viviane Rodrigues Braga (1867-1966), conhecida por Sinhá, e Emilia Rodrigues Braga, conhecida por Yaya (1870-1968). Com a morte dessas duas mães de santo, uma filha adotiva e de santo, Maria de Lourdes Bandeira, mais conhecida como Mãe Badia, herdou a casa e iniciou muitos filhos de santo até seu falecimento, em 1991 (Brandão e Motta, 2002, p. 62). Sobre ela, Motta e Brandão descreveram:

\footnotetext{
Badia hoje está excepcionalmente comunicativa. Lembra os antigos, tios, tias, sua avó Eugênia Rodrigues. As filhas desta Sinhá e Yaya. Os orixás não quiseram subir depois da morte da última, há nove anos. (Ifá, de todo jeito, não sobe, você sabe, sempre tem que alguém ficar zelando). Na sucessão de chefia de uma casa, além da "fala dos santos" tem de haver o consentimento do "povo", que no caso de Badia sucedendo Yaya, foi entusiasmático (Brandão e Motta, 2002, p. 71).
}

Com a morte de Badia e o fechamento da casa enquanto terreiro (a edificação ainda existe, é de posse da família, mas não exerce atividades rituais), a maioria dos santos da casa, em especial Xangô e Oxum, foram levados por Tata Raminho, um dos filhos de santo das Tias, para sua casa, onde são cultuados com muito zelo e estima. 
Tudo isso indica como nenhum fechamento de casa é em princípio definitivo, pois os orixás de uma casa podem continuar agora sob o cuidado de outro "zelador" (notadamente outra denominação comum em Recife para se referir aos sacerdotes).

Em alguns casos, os orixás não são explicitamente passados para os cuidados de outros. E nesse tipo de manutenção de um orixá, não está em jogo somente a existência tangível de assentamentos, de modo que outras experiências envolvendo as heranças podem aparecer como um modo de restituição para a família de santo daqueles orixás que existiram em outros corpos e que podem ser reconhecidos em seus descendentes - esta dimensão envolve certas idiossincrasias da pessoa, características desses orixás quando manifestados em seus filhos. Ao comentar sobre uma filha de santo que tinha a mesma Oya de uma antiga sacerdotisa, a mãe de santo apontava para essa semelhança: "é o mesmo santo", e completou, "ela não conheceu a tia, não a alcançou viva, mas a santa dela é muita parecida, faz o mesmo movimento".

No caso dessas constatações de semelhanças que expressam uma herança, cabe dizer que não se trata de uma aproximação que induz uma identidade total entre o orixá de uma pessoa falecida e o orixá que retorna à família. No enterro de uma importante mãe de santo, um de seus parentes chorava copiosamente e com as mãos no rosto dizia: "nunca mais a Oxum de minha tia, nunca mais a Oxum da minha casa, nunca mais!”.

Isso porque, como comenta Carmen Opipari (2004, p.197), o orixá-personalizado, o "santo", não seria um mero reflexo de um "eu profundo", uma "unificação do ser", mas uma composição entre elementos constitutivos da pessoa que, em seus "componentes espirituais, físicos e sociais, [...] apresenta-se enquanto heterogênea e múltipla”. Essa composição é única, o que motiva um enorme sentimento de perda quando uma pessoa morre e seu orixá não será mais visto por aqueles que conviveram com seu filho.

É nesse sentido que afirmo que a constatação da relação de um santo de uma pessoa com o de uma que já se foi não corresponde a uma identidade total. Ou seja, se um santo existe apenas na composição com a pessoa, quando ele é estendido via herança para uma outra, esta também irá imprimir nessa relação um modo seu, características suas. A ressalva feita por Junior Boto sobre os santos de deixa pode explicitar melhor o que quero dizer. Ao discutir comigo os casos de herança na família, ele me alertou que uma pessoa que tenha um orixá que já pertenceu a outra deve necessariamente passar pelos rituais de iniciação e cumprir suas renovações:

O povo diz 'santo de deixa', 'de herança'. Mas a pessoa tem que dar as obrigações dela, porque a cabeça dela não era a mesma da avó. Ou a cabeça ficou também? A pessoa pode ter o mesmo sangue, mas não tem a mesma 
cabeça, o ori. Cada pessoa nasce e morre com o seu ori. Então tem que cumprir tudo, para depois de passar pelas renovações, poder receber deka e outras coisas. O orixá é de deixa, mas a cabeça não!

Um segundo caso etnográfico que aponta para o caráter diferenciante dessa relação foi o de um filho de santo de Pai Paulo que acompanhei durante minha pesquisa de campo. Ele é uma pessoa bastante ativa na rede de terreiros que compõe a família de santo, além de ser um respeitado juremeiro. Após três anos da morte de Pai Paulo, esse homem resolveu fazer um obori. A casa à qual ele pertence atualmente é uma das que Pai Paulo atuava como pai de santo e que, com sua morte, ficou sob os cuidados de Bino. Ele então pediu que Bino realizasse o jogo, obtendo o veredito de que, além do obori, ele deveria raspar sua santa, Oya, e fazer uma saida de iyawo.

Com muita antecedência, ele começou a comprar as coisas de sua obrigação, a roupa de sua santa, os animais a serem oferecidos. Entretanto, uma reviravolta aconteceu. Faltando pouco menos de um mês para sua entrada de quarto, ele decidiu suspender a feitura. Essa decisão foi decorrente de um pressentimento, atribuído por ele à jurema, de que sua cabeça não deveria ser raspada. Ele então procurou seu sogro, o irmão de Pai Paulo, Tio Cicinho, e pediu para que ele jogasse. Os odus que caíram foram decisivos para que ele não raspasse; expressavam que Oya não queria que ele raspasse sua cabeça, nem abrisse curas. $\mathrm{O}$ jogo terminou com o egum de Pai Paulo confirmando que ele deveria apenas dar a obrigação aos santos. Quando o indaguei sobre o motivo dessa decisão, ele me contou:

"Meu Pai Paulo jogava para mim no opelê - meus santos foram acostumados no opelê, e por isso, agora, o recado do jogo de búzios foi mais difícil de entender, porque tudo meu era no Opelê. Na época [que jogou], Pai Paulo me disse que eu não era de Iemanjá! Mas eu vinha cuidando e cultuando Iemanjá por mais de 20 anos em outra casa. Ele explicou que Iemanjá era o santo da minha família, foi a geradora da família, porque começou com ela, mas eu era de Ode, Oya e Xangô, que são os santos da minha bisavó e já vem do sangue, meus santos são de deixa. Por isso não precisa raspar, tudo meu seria só 'simbólico' - os assentamentos, as saídas - porque esses já eram os santos dela, eles já eram assentados, mas quando ela morreu ninguém quis cuidar. Então eu vou ter de assentar eles de novo, mas só como complemento.

E como eu sempre cuidei mais dos espíritos, da fumaça, Oya passou à frente de Ode, e hoje ela está na frente, porque na minha cabeça sempre foi muita fumaça. Mas eu sou de Odé, o da minha bisavó. Foi isso que aconteceu agora: 
eu ia dar meu obori e o povo falando que teria de raspar, que eu teria que abrir cura. E eu fiquei com isso na cabeça, e fui jogar pra ver se teria de fazer isso mesmo, se eu teria que raspar... Foi quando Cicinho jogou e falou, 'Oya não quer navalha na sua cabeça, porque você mexe muito com a fumaça'. No meu corpo não vai navalha, não vai cura, não tem queimado, porque minha Jurema é assim, não planta semente, não queima. Meu corpo vai embora como veio, sem nenhuma marca."

Os dois últimos relatos, o de Junior Boto e o do filho de santo de Pai Paulo, são em princípio opostos: o de Junior alude para a peremptoriedade da feitura, mesmo em casos de herança, o do filho de santo trata de uma experiência em que a feitura (a raspagem e abertura de curas) foi dispensada, em parte porque os santos eram "de deixa". Em outra medida, esses dois são exemplos complementares em relação à singularidade da pessoa, de seu ori: o filho de santo já havia lavado sua cabeça e, além disso, afirma que a feitura teria um papel de complemento "simbólico"; cabe dizer ainda que o filho de santo fez a saída de iyawo, ainda que sem a raspagem. Esses casos etnográficos permitem apontar como as relações de herança não envolvem identidades totais, ou, ainda, como uma relação interna se diferencia por meio da outra ${ }^{101}$. Além da herança dos santos, esse filho de santo possui forte relação com a Jurema, de modo que a composição que seu sangue induz - ele explicitamente traduz sua experiência religiosa nestes termos, dizendo ter "sangue de negro, índio e cigano" - , possui a implicação analógica da diferenciação, uma condição inerente a esse regime de parentesco. A singularidade do ori da pessoa, como ressaltou Junior Boto, coloca um ponto de descontinuidade em um fluxo de transmissão, marcando, portanto, a singularidade da pessoa e do santo.

\section{AS DUAS INTUIÇõeS}

O que as heranças dos santos evidenciam é um conjunto de práticas religiosas que se relacionariam a determinadas condições de possibilidades. Realizar-se-iam por meio do "legado de sangue" ou, como as pessoas da família gostam de mencionar, "por herança familiar", que

\footnotetext{
${ }^{101}$ Na tese de Paula Siqueira (2012, p. 109-110), há uma passagem sugestiva para o tipo de composição que essa narrativa alude: "Uma pessoa povoada é transpassada por outrens que nutrem com ela relações variadas. [...] Tratase mais propriamente de uma noção de pessoa cujo horizonte estão a existência e a criação de moradas - ou domínios -, onde tanto pessoas como espíritos compartilham as ações de 'ter', 'ser' e 'morar' que, por sua vez, afetam a relação que ambos travam com seus pares e entre si”.
} 
seria o caso específico dos descendentes carnais ou consanguíneos, e por meio da "participação ritual" a partir da transmissão dos conhecimentos rituais.

As heranças não são circunscritas, apenas, às casas de candomblé, tampouco aos assentamentos dos orixás. Elas possuem igualmente uma dimensão intangível e não menos importante: a herança espiritual, algo como um "dom” ou predestinação carregado por uma pessoa em sua constituição. Contudo, esses dons adquirem, por vezes, contornos dramáticos, porque relacionam obrigações e compromissos com universos religiosos distintos, muitas vezes rivais entre si, em relação aos quais a pessoa frequentemente tem de equacionar desejos e vontades conflitantes manifestados por diferentes divindades, além de suas próprias aspirações.

Nesse sentido, como mostrarei nesta seção, noções como herança e descendência implicam também em regimes de participação de diferentes elementos, tendências, eventos e entidades espirituais, tendo o sangue como vetor principal de sua circulação. Essa força referese tanto à relação entre divindades e pessoas quanto aos universos religiosos entre $\mathrm{si}^{102}$. Podemos pensar como o sangue coloca uma questão referente a esses diferentes - e por vezes conflitantes - regimes de existência encontrados no candomblé de Recife. Nesse cenário, é possível dizer que as pessoas convivem e se atentam para a íntima e constitutiva relação entre santos do candomblé e espíritos da jurema e estão constantemente sintonizando essa relação em seu cotidiano ritual.

Em contrapartida, a relação entre santos católicos e orixás, e os diferentes modos de participação deles presentes no candomblé do Recife, pode ser caracterizada pelas analogias entre suas imagens e representações que os simbolizam, como Ogum e São Jorge, Xangô e São João, Oya e Santa Barbara. Esse tipo de associação, no domínio dos orixás, não incide em uma participação ritual específica, mas sinalizam apenas a associação entre as datas de obrigação e os meses destinados a festividades dos santos católicos. Por outro lado, como vimos no segundo capítulo, no domínio dos eguns, a liturgia da igreja católica surge como um conjunto de técnicas rituais necessárias ao conjunto mais amplo da pragmática ritual para se lidar com os espíritos dos mortos. No caso da família Felipe da Costa, podemos inserir ainda um outro domínio

\footnotetext{
102 Edgar Barbosa (2014, p. 23) encontrou uma situação análoga nas casas de culto em Pelotas, sobre as quais descreveu algo inspirador: "em conjunto complexo de cruzamentos em que tomam parte a história ritual dos próprios chefes, a vida pessoal e social de cada um e a agência dos seres sobrenaturais. Se cada casa é um caso é também porque cada chefe é um chefe, cada deus é um deus, cada lado é um lado, e também porque, de tudo isso, não resultam seres indivisíveis, mas formas atravessadas por forças variadas, simultaneamente diferentes e inseparáveis, e que fazem de toda individuação ritual uma maneira singular de compor com a multiplicidade. O que chamo de estilo é precisamente essa singularidade, isto é, esse modo de composição com uma matéria que é fundamentalmente força e cuja textura é sempre heterogênea. O chefe de cada casa é um artesão politeísta".
} 
religioso, o católico. Como mostrarei, esses domínios se colocam para as pessoas por serem heranças espirituais que, conforme descreverei, relacionam-se de maneira heterogênea.

A discussão ocorria após a neta de Mãe Lu mãe de santo do terreiro, relatar um recente caso de racismo que sofrera na escola ${ }^{103}$. A avó da agressora tinha ido se desculpar e Mãe Lú considerou que não "tinha sinceridade" no pedido, especialmente porque a mesma era "crente". Todos na mesa concordaram. Mãe Lú disse que Deus era um só, que ela era católica praticante e que isso vinha de "berço", "já vem do sangue". Pai Paulo consentiu com a cabeça e disse num tom de desaprovação: "Esse povo anda com a Bíblia embaixo do braço, mas não sabem que Xangô é primo de Ismael, neto de Abrãao? Tudo da mesma família?”.

A afirmação sobre o aparentamento entre Xangô e Ismael é sugestiva para pensarmos o lugar do parentesco na relação entre catolicismo e o candomblé nagô no terreiro, em especial ao que aludira Mãe Lu sobre o catolicismo estar em seu sangue. Para além do culto dos orixás, todos na família de santo se consideram genuinamente católicos e praticantes do candomblé, algo que seria tanto transmitido a cada geração quanto uma disposição que as pessoas da família possuiriam. Religião e parentesco seriam, nesse terreiro, coextensivos.

Todos os anos, Mãe Lu realiza inúmeras novenas, uma em especial, no mês de maio, que "é o mês de nossa família ${ }^{104 ", ~ e l a ~ m e ~ d i z: ~ " m a i o ~ e ́ ~ u m ~ m e ̂ s ~ d i f i ́ c i l ~ t a m b e ́ m, ~ l e v o u ~ m u i t a ~ g e n t e ~}$ nossa família, mas é o mês da nossa mãe, Maria”. Durante todas as noites desse mês, Mãe Lú senta-se em frente ao altar de Nossa Senhora da Conceição, que fica no centro da sala principal de sua casa. No centro do altar, há uma antiga imagem de gesso de Nossa Senhora, que fora de seu avô Adão. Ela está ladeada de flores, velas e fotografias dos familiares que já morreram. Logo acima, na parede, uma foto de seu pai Malaquias numa moldura de madeira, que ocupa o lugar principal, acompanhada de imagens de Jesus Cristo, um retrato de sua mãe, outro de sua

\footnotetext{
103 Parte do argumento que se segue, foi publicado de forma preliminar em meu artigo (Filho, 2017) no qual desenvolvo como essa relação opera de modo a não produzir uma equivalência generalizada nos domínios eu se relacionam.

${ }^{104}$ Essa prática é uma tradição que remonta à fundação do Sítio de Pai Adão e foi descrita no livro de Gonçalves Fernandes (1936, p.56-59)sobre o Xangô do Nordeste: “O conhecimento da língua que lhe fora ensinada pelo seu pai lhe fez familiar a religião e permitiu que se aperfeiçoasse na liturgia do culto. Não se livrou contudo do sincretismo católico. Referiu-me mesmo que em Lagos, mercê da volta de muitos antigos escravos, outros, mesmo libertos já de nascença,- o culto yorubano se faz assim mesclado em muitos terreiros. Ao lado da casa Adão tem a sua capela. Ali, toda cheia de santos católicos, imagens e estampas no altar, que toma todo o fundo da sala, bancos de madeira dispostos como se fosse em igreja, fazem rezas, terços. O mez Mariano então é muito concorrido, sendo as orações tiradas por Adão".
} 
única filha carnal, Bárbara, além de um alvará do terreiro datado de 1936. Um retrato desbotado de uma cabocla completa a cena.

Mãe Lu começa a sequência de rezas, algumas em latim, outras ladainhas que ela vez ou outra lê em um velho caderno de páginas amareladas - algumas já puídas pelo tempo -, que teria copiado com sua letra cursiva de outro caderno que era de sua mãe, Dona Josefa. Da genitora ela herdou também a mesa de jurema, que fica em um diminuto quarto de madeira situado na mesma sala:

"Eu continuo aquilo que meu avô Adão fazia todo mês de maio na capela do Sítio. Isso já está no nosso sangue, minha mãe, quando era viva, fazia também. Foi assim que eu aprendi e hoje minha neta me acompanha toda noite, é assim que é, já vem de família, um seguindo o outro, participando das rezas, das missas e das novenas."

A coexistência de rituais presentes nesse terreiro engaja elementos tidos como católicos (missas, imagens de santos, entre outras) e aqueles de outros domínios, tidos como do candomblé (jogo de búzios, ebós, culto aos ancestrais) e jurema (mesa de Jurema, taças, cachimbos, imagens de mestres, a bebida da jurema). Em vez de fixar tais elementos como categorias fixas e dadas a priori, procuro me atentar às relações contextuais em que a diferença entre eles é precipitada e qual a importância dada pelos praticantes do candomblé em destacála. Tais composições entre domínios entendidos como separados (não fechados) não ocorrem em relação apenas ao catolicismo, mas são presentes entre os diferentes contextos e espaços do candomblé nagô; eles coexistem necessariamente, uns a partir dos outros, sem que suas diferenças sejam subsumidas. Neste ponto me volto a Pai Paulo:

"Eu tenho por tradição familiar do lado materno muita coisa de Jurema, minha avó e meu avô maternos eram grandes juremeiros, minha mãe. No dia em que eu nasci, o mestre da minha mãe, Manoel Deitado, veio e disse que ia nascer um menino que trabalharia com os astros. Eu chorei na barriga da minha mãe. Aí, quando meu pai chegou do trabalho encontrou minha mãe arrumando a casa, perfumando, tinha trocado as cortinas, aquela coisa toda. E ele perguntou: pra que isso tudo? E ela disse que eu ia nascer naquele dia, que o mestre dela tinha avisado. Meu pai deu risada e não levou a sério, mas eu nasci naquele dia. No dia três de fevereiro, dia de São Braz, por isso Paulo Braz, Paulo em homenagem ao meu avô materno, que lutou na guerra do Paraguai: José Paulo de Ananias. Eu não fui muito pelo lado da jurema como 
Lucinha [Mãe Lu], por 'lavagem cerebral' do meu pai. Mas não pode misturar, Jurema é uma coisa, candomblé é outra. Eu estava escrevendo As Memórias de Paulo Braz, aí fui falando sobre o dia a dia do meu avô, aquelas coisas todas que meu pai contava. Quando deu 70 páginas, eu vim descrevendo o lado materno, das heranças espirituais, dos mestres e aí o computador apagou tudo o que eu tinha escrito. Pra você ver como as coisas são, não pode misturar, isso já vem das tradições espirituais do meu avô. Ele sempre mandava a pessoa que caía esse odu procurar uma casa de jurema."

No terreiro, a coexistência desses universos, como insistem meus anfitriões, é, antes de tudo, presente no corpo, na pessoa, em seu sangue; e consequentemente disposta nos espaços rituais da casa. Desse modo, o sangue e mesmo a pessoa não conduzem a um híbrido e, principalmente, a uma síntese entre essas distintas origens ou traços. Tal relação poderia ser expressa então como uma equação, uma soma $\mathrm{A}+\mathrm{B}=\mathrm{C}$, sendo 'A' a parte dos orixás e 'B' a parte da Jurema, por exemplo. Não obstante, se tal equação existir, me parece algo similar a uma equação do tipo $\mathrm{A}+\mathrm{B}=\mathrm{A} / \mathrm{B} \cdot{ }^{105}$ Entre a proporção $\mathrm{A} / \mathrm{B}$, caberia mais uma proporção, referente à própria pessoa que está contida nessa fração. Uma elaboração de Paulinho ilustra o modo como ele pensa essas suas heranças, qual seja, como duas intuições:

"Aqui em casa, todo mundo tem duas intuições, uma da parte do meu avô, os orixás, e outra pelo lado de minha avó, que é a parte da jurema. Eu não sou muito dentro das coisas de jurema, porque sempre fui mais por painho, pelos orixás, e porque sou de Orixala, e ele não aceita muito a fumaça, os espíritos da jurema. Mas todos nós os temos. Da minha mãe, eu também herdei coisas da jurema, mas quem cuida mais é Bino."

A Jurema, na casa, seria uma herança de Dona Leônidas, filha de uma família de importantes juremeiros, ou, como Mãe Lu sempre diz, "do povo índio mesmo, dos Canindés". Todos os objetos rituais, copos e taças preenchidos com água - chamados de príncipes e princesas -, são dispostos em uma mesa junto de cachimbos, preacas ${ }^{106}$, maracás. São caboclos e caboclas, mestres e mestras e exus e pomba-giras, as entidades espirituais do mundo da jurema. Estes últimos residem em uma pequena casa na entrada do terreiro. A separação desas

\footnotetext{
${ }^{105}$ Inspiro-me no excelente material e análise de Eduardo Nunes (2013). "Socialidades alternativas: sobre o conceito de cultura dos Karajá de Buridina". Arquivos Do CMD, 1(1).<https://doi.org/10.26512/cmd.v1i1.7496>. ${ }^{106}$ Preacas são pequenos arcos e flechas de madeira que produzem um som característico quando se puxa a haste e a solta produzindo um estampido. São utilizados também nos Caboclinhos, agremiações carnavalescas do Recife e Mata Norte de Pernambuco.
} 
entidades acontece porque eles pegam sangue ${ }^{107}$, diferentemente dos mestres e mestras, caboclos e índios da família. Entende-se que essas entidades são "espíritos" de pessoas falecidas, que retornariam entre os vivos para "trabalhar" - encontramos aqui mais uma diferenciação.

A diferente natureza dessas entidades - orixás e espíritos - implica em uma diferença em suas expressões como heranças. Enquanto um orixá de herança é entendido como uma divindade que pode ou não se manifestar no corpo da pessoa que a herdou, mas que já não seria exatamente a "mesma divindade", os espíritos são entendidos enquanto os mesmos espíritos que trabalhavam nos corpos dos antepassados. Mãe Lu ressalta que essa diferença se dá porque os orixás são "a natureza encantada”, mas os espíritos seriam "almas, eguns" que viveram na terra e possuem atributos, como memória, além da lembrança do seu trabalho em antigas matérias. É essa capacidade que atestaria serem alguns deles os mesmos espíritos que atuavam nos antepassados de uma pessoa, pois eles se lembrariam de eventos e situações vividas no passado da família com precisão, sendo isso a confirmação da veracidade da possessão.

Sendo assim, a jurema da família de Mãe Lu seria de sua avó e tias, sendo recebida pela mãe de santo após a morte de sua tia, e ao qual ela acrescentou ao seu "próprio" conjunto de entidades. Esses mestres de herança seriam repassados, após a sua morte, ao seu neto Thalysson, mas ela adverte que somente após a sua "passagem" é que ele começaria a incorporá-los. Essa ressalva é feita em contraposição ao fato de que uma pessoa de sua família começou a trabalhar com uma dessas entidades, causando muita desconfiança na sacerdotisa, dado que "eu ainda estou viva”. O que aumentou sua desconfiança a respeito do espírito ser efetivamente o mesmo mestre que ela herdou foi o fato dessa pessoa alimentar esse espírito com porcos e bodes, o que, na visão dela, diminuiria ainda mais a possibilidade dele ser verdadeiramente o mesmo mestre, dado que ele nunca teria recebido esse tipo de oferenda: "minha mãe e minhas tias tinham horror a sangue! Por isso, quando ele baixa aqui, ele sempre está zangado, que estão dando isso a ele”.

À exceção de Mãe Lu, poucas pessoas na família trabalham efetivamente com o lado da Jurema. As pessoas justificam a preeminência da mãe de santo com base na sua "mediunidade muito forte". Desde pequena ela recebia os espíritos da Jurema e seu sobrinho Guara recorda que, quando pequeno, muitas vezes acordava com Mãe Lu possuída por algum mestre ou outra entidade. Ela me explica que, quando nasceu, a parteira, também uma juremeira, havia dito à sua mãe que a criança possuía um corpo médium e que iria trabalhar com a ciência. Ainda assim, e em conformidade com o que falam Paulinho e Pai Paulo sobre a força do "lado do 
santo", seus rituais são esporádicos e se concentram, sobretudo, em agosto, mês de festa especialmente dedicada aos espíritos em Recife.

De modo geral, o nascimento opera como uma importante "confirmação" da relação que o sangue vincula entre pessoa e divindades, espíritos e ancestrais - a confirmação é expressa muitas vezes no próprio nome da pessoa. Como mostrei anteriormente, nascer, por exemplo, no dia 2 de novembro, dia de finados, pode sinalizar que a pessoa tem relação com os eguns, como no caso de Malaquias (Ojebii, nascido como Ojé, sacerdote dos eguns) ou que a pessoa é filha de Iansã, como no caso de Betânia, primeira esposa de Pai Paulo, mãe de Bino e de Paulinho.

"Para você ver Olavo, como são as coisas. Paulinho tem uma intuição muito forte, ele às vezes chega e me diz as coisas e quando eu vou ver é daquele jeito mesmo. Ele tem muita parte com a Jurema, a mãe dele teve ele ali naquele quarto que hoje é dos meninos, onde ele dorme. A mesa de Jurema de minha mãe ficava ali, ele nasceu embaixo da mesa porque a mãe dele teve ele ali, já nasceu próximo dos mestres, é muito forte a ligação dele (Mãe Lu)."

Na mesma medida, a relação com a Jurema pode ser pensada também como uma “confirmação" em um universo em que a mistura ritual entre esses dois domínios religiosos é sempre evitada.

Há alguns anos, a participação da família na jurema, antes restrita à reunião da mesa, começou a ser mais intensa. Deve-se a isso a chegada de filhos de santo que possuíam suas juremas em suas próprias casas ou em outros terreiros (é muito comum em Recife uma pessoa ter seus orixás em uma casa e cultuar sua jurema em outra). Essa adesão também aumentou a partir de casamentos ou relacionamentos conjugais com pessoas que possuíam uma vinculação mais forte com a jurema. Há ainda pessoas da família que em sua própria trajetória de vida, em determinado momento, receberam um recado ou mesmo foram possuídas por essas entidades e eventualmente passaram a trabalhar com elas no terreiro.

Devido à intensa atividade ritual da parte dos orixás, os resguardos e intervalos necessários para se acessar o lado da jurema são sempre menores em relação à parte dos orixás. Estes dominam a vida religiosa da casa. Isso também se justifica pelo constante risco de a “fumaça ofender o santo". Iemanjá é considerada um orixá particularmente avesso à presença dos espíritos (os outros seriam Xangô e Orixá Oguiã, extremamente presentes na família). Quando os rituais da Jurema acontecem próximos ao peji, as pessoas sempre ficam atentas para 
que não entre fumaça em seu interior. Houve anos em que a própria divindade proibiu rituais para a Jurema no barracão do terreiro.

Nesse caso, a lógica de compensação das obrigações entre os orixás é estendida para a relação entre o nagô e a jurema, de modo que os dois universos são distintos e coexistem no terreiro, mantendo uma interação entre si na qual o equilíbrio entre os mundos é sempre frágil. São universos que se afetam frequentemente e, quando a relação se torna muito assimétrica ou quando os domínios tendem à proximidade (temporal, espacial) excessiva, o conflito irrompe e seus efeitos são prejudiciais ao terreiro e aos integrantes. Essa coexistência, assim, não impede que existam perigos e rivalidades entre esses universos. Certa vez, durante uma obrigação para Iemanjá, Pai Paulo pediu para que eu conferisse se havia algo no quarto dos exus da jurema esse quarto se encontra na frente da casa, próximo ao local em que Pai Paulo costumava se sentar para aproveitar a sombra da árvore. Não encontrei nada além dos assentamentos dos exus e ele me alertou: "Veja se não tem nada embaixo, tô sentindo um cheiro vindo dá'". Levantei o assentamento e não encontrei nada. Ele então me disse: "Eles ficam fazendo obrigação pra jurema com o 'santo arriado', por isso dá problema, essa confusão toda pode ter sido por isso. Eu não misturo, faço como meu Pai e meu avô faziam". Note-se, porém, que a censura de Pai Paulo não incide sobre o fato de as entidades da jurema residirem no mesmo terreiro, mas, sim, sobre possíveis misturas entre Jurema e nagô, como, por exemplo, seus rituais serem realizados em períodos relativamente próximos, incorrendo em algo extremamente perigoso, de acordo com a teoria do nagô, e, nas palavras de Pai Paulo, "incorreto":

"A gente não vê mais a Jurema como era na minha família, os mestres e mestras, aquilo vinha e dava muita emoção, eu não sinto a mesma emoção. Hoje é Maria Padilha, exu, mas naquela época não, era só mestre mesmo, cada mestre que dava até medo. A gente sentia aquela emoção forte... Mestre de antigamente era só fumo, cachaça, água. Não tinha nada com sangue, não matava pra eles não, mas hoje até cabra dão! Eu acho que não pode misturar, cada um com aquilo que era antes."

Pai Paulo fez alusão a outras entidades hoje cultuadas nos rituais de Jurema, mas que não faziam parte de seu panteão anteriormente. Apesar da "incorporação" dessas novas entidades, é de se notar que, nas obrigações de jurema, os exus e pomba-giras são tratados antes dos mestres e mestras, não recebendo oferendas no mesmo espaço ou ao mesmo tempo que estes, o que parece replicar, nesse contexto, determinadas separações rituais ligadas aos tipos de seres ali cultuados. Esse é o argumento, por exemplo, de Mãe Lu para justificar porque o 
Sítio de Pai Adão talvez seja um dos poucos terreiros em Recife a não ter nenhuma relação com esse universo:

"No Sítio não tem jurema! E se eu souber que alguém colocou alguma coisa de Jurema ali, vou ser a primeira a ir despachar tudo! Ali era só de africanos mesmo, não tinha jurema. Agora muitos decendentes de lá têm Jurema sim, porque depois, no Brasil, os africanos foram casando e se misturando. Então os filhos e netos começaram a ter índio, caboclo, mestres. Mas não pode cultuar lá. Tem primo meu que mora lá e tem, mas não faz nada dentro do Sítio. Tem que fazer fora. Aqui nós temos a Jurema, que era de minha mãe, minha avó Maroca. Ela morava no terreno ao lado do Sítio. Uma vez ela foi jogar com meu avô Adão. Ele viu que ela estava devendo algo para a Tapuia e mandou que ela fosse pagar essa dívida. Era porque ela, muitos anos antes, tinha ido na mata buscar lenha, era perto do Sítio, mas ela se perdeu e não conseguia voltar. No desespero, ela pediu ajuda a Tapuia Canindé, então ela começou a ouvir um tambor batendo, tum tum tum, e se aproximando, até que ela viu uma menina baixinha, com o cabelo até o chão. Era a Tapuia Canindé. Ela foi por onde a menina apareceu e quando viu já estava fora da mata. Mas se esqueceu de ir na mata levar o mingau que tinha prometido. Meu avô era fogo, veja como era o jogo dele, como ele saberia disso? Ele não tinha nada com Jurema, mas o jogo avisou, sempre que aparecia no jogo alguma coisa de Jurema, e ele mandava procurar minha avó...

Encontramo-nos novamente com o tema da descendência e com uma noção de família que não se explica por elementos distintos e totais em si, mas, sim, indissociável da noção de força. Como descrevi nesta seção, é por meio da descendência, pelas linhas que perpassam as pessoas através do sangue, que se garante que as pessoas de uma família recebam de seus antepassados, seus dons espirituais, suas capacidades de cuidar dos orixás e as responsabilidades que essas heranças implicam. Dessa perspectiva, os dons e heranças são encarados enquanto vias de transmissão de um conjunto de características, técnicas rituais e conhecimentos dados pelo fluxo familiar. Mas, conforme apresentado, essas caracteristicas não estão garantidas, tampouco as relações familiares operam como uma garantia. Além desses “conteúdos" se imporem às pessoas como forças com as quais elas devem lidar cuidadosamente, a família e a descendência, mais que circunscrições, são linhas que operam no interior desses relacionamentos, singularizando-se nas pessoas. 
Desse modo, a interação entre os regimes de existência dos orixás e da jurema implica necessariamente na relação de forças entre esses seres. O sangue é um dos vetores dessas forças que seguem as linhas de transmissão entre pessoas, mas não é o único, pois a cor da pele e o fenótipo racial são também índices demonstrativos da vitalidade desses regimes.

Assim, se a descendência está expressa na personalidade das pessoas, em sua constituição do sangue como veículo da espiritualidade, essa mesma lógica se estende aos seus traços físicos. Entre as pessoas com quem convivi nos terreiros, a ampla maioria se constituía de pessoas negras. Notadamente elas elaboram sua negritude numa gradação de termos, como: preto, negro, escurinho, pardo, marrom, sarará. Em muitíssima menor escala, estão os brancos, tanto em quantidade quanto em gradação de termos: os poucos brancos são sempre brancos. A existência de todos esses termos aponta para como a negritude é entendida ali a partir de uma riqueza cromática que envolve uma forte conexão com a África e os orixás.

Arnaud Halloy (2010) percebeu essa característica dos membros da família ao relatar um evento etnográfico em que parte da família estava reunida assistindo a um jogo entre Brasil e Nigéria. Nele, Tia Zite divertia-se associando seus familiares aos jogadores da seleção africana:

Zite se divertiu comparando-os com membros da família dela: 'Olha, aqui é o Paulo, aí está Bíno! Mas olha, esse é Paulinho todo!’ O que foi surpreendente foi que ela repetiu esses três nomes várias vezes, e nem uma vez a de seu filho. Uma vez o hino da Nigéria terminou, Júnior virou para sua mãe e gritou para ele: 'E eu?' Zite então percebeu seu constrangimento e exclamou: 'Você também tem sangue africano!' Eu acho que a omissão de Zite, não obviamente intencional, mas também não foi por acaso. Está enraizado na ideia culturalmente significativa - mas amplamente implícita - que 'descendência africana', como os membros do culto às vezes o chamam, é transmitido principalmente pela linha paterna. Quando é estabelecido através da mãe, é a situação de Júnior, seria mais fraco ou incompleta. Essa diferenciação é ainda mais acentuado no caso de Júnior do que seu pai era considerado 'branco' por sua família. Júnior, ele próprio um 'mestiço escuro', teria herdado a 'brancura' de seu pai, como Paulo disse uma vez explicitamente: 'É por esse motivo que Júnior é branco, porque o pai dele era branco...' Novamente, o termo 'branco' não se refere a nenhum caráter fenotípico, mas bem a um ideal agnático da herança africana (Halloy, 2010, p. 5).

Situações como essas são cotidianas e, em geral, vividas com muito humor pelas pessoas da família. Pai Paulo tinha um grande amigo nigeriano, e seus filhos e sobrinhos se divertiam muito descrevendo algum jovem sobrinho ou filho de santo como "fulano II". Os filhos e sobrinhos de Pai Paulo costumam se nomear como "Os Abelhas Africanas", apelido dado por uma antiga filha de santo de Pai Paulo que costumava reclamar do elevado consumo de cervejas com que eles estavam habituados. O que era uma ofensa transformou-se rapidamente em motivo de orgulho e afirmação. Sobre esse tipo de acusação, Pai Paulo respondia evocando o orgulho em descender de africanos. Em uma outra ocasião, e em outra casa, o velho pai de santo teria 
se "arretado" e dito: "os meninos são como eu, meu antepassado sofreu e sangrou, mas adorava os santos, e os seus? Estavam sentados na Casa Grande enquanto os nossos sofriam!”.

Mas há mais a se dizer. A percepção da clivagem agnática na constituição racial da pessoa expressando a descendência africana não me parece explicar tudo. Entendo que aquilo identificado por Arnaud Halloy como um ideal agnático talvez fosse melhor entendido como um corte nas linhas de força que compõem tanto pessoas como terreiros no candomblé do Recife. Na família, a linha de transmissão africana é identificada pela prevalência de ancestrais masculinos. Mas as mulheres ascendentes não estão excluídas dessa linha. Parte importante dessas heranças dos orixás e eguns é recebida pelas pessoas por meio de suas mães e avós. É sempre a perspectiva da pessoa ao traçar suas genealogias que deve ser levada em consideração.

Bárbara, filha de mãe Lu, afirma que seu orixá Oguian seria oriundo da descendência de seu pai, Marrom (que é também de Oxalá) - nesse caso podemos estabelecer uma ênfase agnática. Todos naquela família teriam esse orixá como predominante. Thauany, filha de Bárbara, é de Ogum, e esse seria o orixá de seu pai, predominante na família do mesmo que, por sua vez, é a família fundadora de um dos importantes terreiros da nação Xambá em Olinda. A linha ascendente dessa família, entretanto, focaliza uma mulher filha desse orixá como a geradora da família ${ }^{108}$.

Um outro caso parece corroborar a hipótese de que as mulheres não estão tão à parte assim. Idelfonso, um dos meus principais amigos em Recife, é descendente de uma das famílias tidas como fundadoras do Sítio. Todos os ascendentes de sua família evocados para explicar seus vínculos com os orixás, e mesmo com a África, seriam do seu lado materno, todas mulheres, sendo a mais antiga delas Tayo Gululu, uma das principais filhas de santo de Tia Inês, lembrada até hoje por ser uma das únicas capaz de acalmar Pai Adão. Desse modo, tanto os ascendentes agnáticos quanto uterinos compõem as linhas de participação dessas forças, de modo que a prevalência de uma sobre a outra não deve ser entendida como uma regra ou ideal.

Nesse sentido, devemos lembrar que o que descrevo aqui não se trata de um sistema ou regras de transmissão, mas de regimes de força. No caso dos filhos de santo brancos, não é posta em dúvida sua filiação aos orixás e muito menos aos ancestrais da casa, muito embora uma das primeiras obrigações realizadas no momento da feitura seja o de vincular a filiação

108 Trata-se de Dona Biu, antiga mãe de santo da casa Ilê Axé Oya Meguê. 
desses filhos aos eguns da casa, porque eles seriam mais fortes e teriam melhores condições de proteger esses filhos e levar seus pedidos aos orixás ${ }^{109}$.

Não somente os vínculos aos orixás podem ser reconhecidos nas características fenotípicas das pessoas, como podem ser sobrepostos às relações entre os domínios religiosos. Uma filha de santo que tinha ido jogar com Mãe Lu para fazer a sua iniciação foi alertada por Pai Paulo que deveria, antes de tudo, cuidar de seu índio. Ele reconheceu em seus traços físicos, a tez morena, os cabelos lisos, os olhos negros, o que o levou a uma vinculação com os caboclos da jurema, que no caso dessa moça, eram tidos como mais fortes do que dos orixás.

Pai Paulo, em diversas oportunidades, afirmara que também tinha parte da jurema, e que esta seria oriunda do seu lado materno, mas que esse lado é obliterado por uma disposição sua em decorrência da influência de seu pai. Tais disposições não estariam apenas no seu sangue, mas também em sua raça, na sua pele:

"Isso que eu tô te falando está na minha pele, na minha raça, minha descendência africana foi reconhecida na África, ela é mais forte, ganhou! Pela parte da minha mãe, o meu bisavô materno, José Paulo de Ananias (Pai Velho), lutou na guerra do Paraguai, e tinha uma bala alojada na perna, deixando sequelas. Ele era filho de português e a mãe africana; mas a parte do meu pai ganhou, é só você olhar pra minha pele. Que nem a foto de meu avô Adão, eu e meu amigo, arrumamos ela, eles clarearam a foto, mas meu avô era filho de africanos, era bem escuro. Quando Gilberto Freyre fez aniversário $^{110}$, teve uma festa no Sítio, que Manoel organizou. Ele estava lá

\footnotetext{
${ }^{109} \mathrm{~A}$ esse respeito, sobre a presença de brancos nesses regimes de força, Bastide escreveu: "Em suma, o branco só participa das participações por meio de uma ação fabricada, que tem a função de situá-lo no sistema de classificação de forças que o negro trouxe da África" (Bastide, 1953, p.39).
}

${ }^{110}$ Sobre essa "festa" a qual alude Pai Paulo, José Jorge de Carvalho (2005) descreve uma passagem ilustrativa de qual critica Pai Paulo deixa transparecer sobre a presença de Gilberto Freyre no Sitio. "Quando assisti ao documentário Casa Grande \& Senzala, de Nelson Pereira dos Santos, sobre a vida e a obra de Gilberto Freyre, pude rever uma cena que havia presenciado ao vivo em 1980, quando fazia minha pesquisa de campo de doutorado no xangô do Recife. Nelson Pereira havia reproduzido alguns segundos de uma reportagem da TV Globo pernambucana sobre um toque de orixás ocorrido no Sítio de Pai Adão de Água Fria em abril de 1980, como parte das homenagens aos 80 anos do grande escritor. Obviamente, as imagens do noticiário inseridas no documentário passavam a impressão de que aquela comunidade de santo havia oferecido aquela festa em honra de Gilberto Freyre, o qual dizia ter sido amigo do famoso sacerdote Pai Adão. Seus descendentes celebravam, assim, a continuidade dessa relação tão íntima e fraterna entre brancos da elite e negros pobres descendentes de ex-escravos, exatamente como reza a ideologia da democracia racial plasmada no livro Casa Grande \& Senzala. O que o documentário não esclarece é que aquela festa não foi uma manifestação espontânea de apreço do povo de santo ao escritor. Naquela época, eu residia na casa do pai de santo que oficiava no Sítio de Pai Adão e pude acompanhar de perto todas as negociações e os preparativos para aquele espetáculo enganoso. A Fundação Joaquim Nabuco havia solicitado ao pai de santo que organizasse um toque para os orixás especificamente em homenagem a Gilberto Freyre na semana em que ele completava 80 anos. A festa foi paga inteiramente pela Fundação, que alocou dinheiro para todos os gastos de um toque público para os orixás (recursos para a comida, as bebidas, as 
com a família toda, estudantes, e eu já tinha bebido algumas, estava tocando, ai parei o toque e disse: 'professor, meu avô era da minha cor' e bati no meu braço... O velho era negro como eu!"

Considero a evocação de Gilberto Freyre na narrativa de Pai Paulo significativa, ela surge como uma advertência que o pai de santo faz das nossas teorias da democracia racial e uma colocação própria acerca do tema da miscigenação. Note-se que não há síntese na proposição de Pai Paulo: as diferenças - o sangue de índio e o de branco - persistem na sua história familiar, não se anulando na fixação de sua negritude. É dizer, de acordo com o proposto por dos Anjos (2006), que a raça funciona como um percurso nômade, quando pensada a partir de um modelo filosófico da religiosidade afro-brasileira cuja máquina conceitual é por excelência "não essencializada":

Sendo a racialidade vivenciada como um ponto de vista que se 'ocupa' de um corpo, como intensidade histórica [...] um outro modelo para o encontro das diferenças que é rizomático: a encruzilhada como ponto de encontro de diferentes caminhos que não se fundem numa unidade, mas seguem como pluralidades (Anjos, 2006, p.23).

As "intuições" que nomeiam essa sessão, expressas na fala de Paulinho, explicam sua relação com a jurema e com o candomblé. Jurema, candomblé e mesmo catolicismo, menos que domínios bem delimitados de práticas, objetos, pessoas, divindades, conformam-se em presenças que se colocam para esta família - e, no caso da jurema, para quase todo o povo de santo do Recife - e com as quais se deve compor de maneira cuidadosa.

Essa constituição está prevista no sangue das pessoas, em suas características pessoais de personalidade e traços físicos, além, como já demonstrei, da distribuição temporal e espacial das atividades rituais. Meu objetivo nesta seção foi demonstrar como as explicações sobre herança elegeram algum vetor: aquilo que receberam de seus ancestrais - ou pela ação direta de um ascendente direto ou pela intermediação do jogo de búzios para expressar a vontade de

roupas, os tambores, ogãs, os fogos, a limpeza e os arranjos do salão, etc.). Ou seja, mesmo tendo ocorrido durante o mês de abril, aquele não foi o costumeiro toque de Ogum do Sítio de Pai Adão. A festa incluiu até uma pequena palestra de Freyre explicando para uma comunidade de santo um tanto perplexa com sua presença como o negro foi co-colonizador do Brasil. O evento foi filmado também com a finalidade de ser exibido no noticiário local e nacional. O que me parece importante acrescentar às leituras e análises que se fizeram e se façam do documentário de Nelson Pereira dos Santos é que aquela festa foi encomendada e paga pelo próprio homenageado (Freyre era então o Presidente da Fundação Joaquim Nabuco). Sem a intervenção e o financiamento da Fundação Joaquim Nabuco e sem a mediação específica daquele pai de santo, estou plenamente convencido de que aquela festa de homenagem jamais teria existido. Freyre simplesmente não mantinha nenhuma relação com o povo de santo do Nagô pernambucano e a imensa maioria dos adeptos presentes naquele toque nem sequer sabiam quem era o aniversariante"(Carvalho, 2005, p. 06-08). 
um orixá ou egum - como explicação para a expressão do “dom”, mas essas não são regras de transmissão, são sempre instanciações dessas relações, não definidas como uma formulação prescritiva.

\section{SANGUE E HERANÇA: UM MODO DE PARTICIPAÇÃO}

De modo geral, o debate sobre "dom" e "iniciação" se destacou na literatura antropológica a partir da década de 90, ganhando centralidade na última década, com destaque para a revisão e nova proposta de Marcio Goldman (2012), que define a questão situando-as:

[...] das relações entre o que, nessas religiões, seria considerado como da ordem do "dom" e aquilo que elas pensam derivar do campo da "iniciação". Ou seja, relações entre o que o sujeito recebe independente de sua vontade e de suas ações - o "dado", como se costuma dizer - e o que depende de um conjunto de rituais mais ou menos tradicionais, que só podem ser desempenhados com o consentimento do sujeito e sob a condução de iniciados mais antigos do que ele - ou seja, aquilo que é "feito" (Goldman, 2012, p. 169).

Como vimos, a questão das heranças espirituais em Recife pode ser pensada nos termos de um "dom", uma característica recebida por uma pessoa, que a singulariza em uma ampla rede de relacionamentos (de parentesco consanguíneo e espiritual), muitas vezes anterior à sua própria existência. Podemos perceber parte dessa rede nas discussões de Arnaud Halloy:

\footnotetext{
Dois modos de transmissão religiosa são normalmente distinguidos em minha família de santo. O primeiro, que seria específico dos descendentes biológicos do Pai Adão, é concebido sob o modo da "herança": de maneira quase atávica, os saberes religiosos são transmitidos "pelo sangue" de uma geração de chefes de culto à seguinte. $\mathrm{O}$ segundo modo sublinha a importância da iniciação e acentua a necessidade de transmitir os saberes (Halloy, 2005, p. 681).
}

Não obstante, as duas modalidades de aprendizado apresentadas se relacionariam a determinadas condições de possibilidades que destacadamente se realizam através do "legado de sangue" ou, como Pai Paulo gostava de mencionar, "por herança familiar" e por meio da "participação". Contudo, conforme procurei mostrar até aqui, a convivência e a iniciação são, frequentemente, justapostas, confundidas e, às vezes, contradizem-se - não são bem definidas e carregam uma ambiguidade potencial.

Outro fator a ser levado em conta, segundo Halloy (2005, p. 681), é o "tempo" em que “o indivíduo entra e se engaja na adoração". Quanto antes a pessoa começa a aprender, mais valorizada é a capacidade pela qual os conhecimentos são adquiridos. Nesse ponto, a 
ambiguidade é amplificada no caso dos indivíduos que "já nascem sabendo". Como Pai Paulo explicou para Halloy (idem, p.): “eu nasci já elevado! Temos o conhecimento que vem de baixo para cima... ele deve vir a partir da essência... Nós adquirimos hábitos, conhecimento... A criança está descobrindo tudo isso ...”.

Goldman (2012a), comentando o trabalho de Halloy (2005), retoma o tema da "participação", cuja acepção ganha dois sentidos no argumento: a participação-sociológica, no sentido do acompanhamento individual de procedimentos rituais, "ter convivência"; e a participação-ritual, que consiste em "etapas" de aprendizado envolvidas na iniciação e suas repetições da qual a pessoa é destinatária. Com vistas a discutir as implicações teóricometodológicas provocadas pelo uso do termo, Goldman (idem, p. 277) ressalta como o conceito acaba reduzido ao seu sentido estritamente sociológico. Como aponta o autor, o sentido de participação “pode ser entendido em uma acepção propriamente ritual. 'Participar' não é apenas "conviver, mas também entrar em relação, material ou não, com aquilo que constitui o ritual".

Gostaria de me deter um pouco mais nessa discussão. De acordo com Goldman, a "transmissão por participação" diria respeito tanto ao que se aprende quanto ao que é "recebido". Nesse sentido, "sangue, ritual e convivência constituiriam, assim, os vértices de um modelo triangular que colocaria em xeque a concepção dualista de Boyer [Dom e iniciação]" (idem). Assim, se os dois primeiros termos associados (sangue e ritual) poderiam ser da ordem "do dom e da iniciação", o terceiro, "participação", seria mais "indefinido" (idem). Há, nesse ponto, uma reflexão que considero importante transcrever por inteiro:

Evitemos aqui, contudo, o vício profissional que nos levaria a apenas acrescentar uma dimensão "sociológica" ao par "biológico-cultural” inicial. Muito pelo contrário, creio que o terceiro elemento permite justamente o passo essencial: a percepção do caráter em última instância monista do sistema - ainda que esse monismo de base seja apenas a resultante de uma multiplicidade intensiva de linhas de forças e vetores [...]. A hipótese aqui em jogo, portanto, é a de que o caráter aparentemente triádico do modelo nativo não apenas contesta o dualismo dos antropólogos, como oculta, na verdade, um monismo de base. Isto porque o que Halloy denomina "herança pelo sangue" e o que eu mesmo desdobrei em "participação-sociológica" e "participaçãoritual" têm um mínimo denominador comum. Ou, para ser mais preciso, constituem atualizações de um princípio subjacente único.[...]Essa força - o axé, dos candomblés ketu, ngunzo, dos angola, ou simplesmente força, energia, em inúmeras outras religiões deste tipo - constitui tudo o que existe e pode existir no universo, seguindo um processo de diferenciação e individuação, sua unidade garantindo 'que tudo participa de tudo' e suas modulações fazendo 'com que haja graus de participação’ (Goldman, 2012, p. 278-279, grifo meu). 
Essa formulação, ou "lei da participação 111", foi "recuperada" por Roger Bastide (1973), para quem seria um engano supor que a lei de participação é prova da não existência do princípio de contradição entre os "primitivos". Para o autor, o que sucederia é que as contradições do pensamento primitivo são místicas e não objetivas (Bastide, 1973, p.333). Tornar-se-ia mais frutífero, então, pensar a participação como categorias da ação. Para Bastide, os "processos de participação" tendem a ocorrer no interior de classes, entre as quais predominam relações de separação entre diferentes domínios: mortos e vivos, orixás e humanos. Contudo, afirma Bastide,

Tudo não participa de tudo, pois doutra forma o pensamento racional, que existe em todos os homens, não poderia apreender o real, tornando impossível $\cdot 0$ contrôle ou a utilização das forças da natureza. As participações só ocorrem dentro de quadros bem delimitados, e entre êstes quadros diversos não há ligações (Bastide, 2001, p.242, meus grifos).

O “pensamento africano", diz Bastide (1973, p.341), então, não poderia ser definido nem pela participação de Lévy-Bruhl, tampouco pela classificação durkheimiana, mas, sim, colocado em termos complementares; a participação, eu diria, obviaria ${ }^{112}$ a classificação: ao classificar "forças" e "participações", em vez de "seres".

Nesse sentido, o autor estabelece que essas relações envolveriam três princípios simultâneos: o da participação, pelo qual as cadeias de participação são interrompidas quando se passa de um nível real a outro; o do corte, de modo que as participações atuam no interior de um determinado sistema classificatório, cores, vegetais, divisão do mundo, e esses fluxos são interrompidos pelo "princípio do corte". E o terceiro, o das correspondências, que se dariam entre as diferentes classes. Não há participação de um domínio da natureza em outro, mas, sim, analogias, por exemplo, entre o plano social e o plano místico.

De certo modo, o princípio de corte de Bastide, embora destacando os regimes de força que compõe o universo do candomblé, compartimentaliza esse universo em quadros sinópticos de onde emergiriam as analogias e correspondências.

\footnotetext{
111 Podemos retornar à noção de participação, advinda do clássico trabalho de Lévy-Bruhl (1910 Et al.), em especial, ao postulado do pensamento "primitivo", que, diferente dos ocidentais, ignoraria o princípio da não contradição. Dessa forma, a "mentalidade primitiva" tenderia a relacionar e conectar todos os elementos do universo por meio de um continuum de forças espirituais, ligadas por ações e reações místicas, estando "preocupado sobretudo com as propriedades e forças místicas dos objetos seres, concebe a relação entre eles sob a lei da participação, sem se inquietar com contradições que um pensamento lógico não poderia mais tolerar" (Lévy-Bruhl, 1910, p. 110)".
}

112 Nos termos de Roy Wagner(2010) para o qual a obviação estaria ligada a relação entre dois modos de significação, convencionalizantes e a diferenciante, que estão necessariamente envolvidos em todo ato de simbolização eles são ao mesmo tempo interdependentes e contraditórios entre si. 
Edgar Barbosa (2014), ao retomar esse princípio bastidiano, joga sua atenção não para as cristalizações que o princípio de corte opera, mas para seu movimento intervalar, de onde ele extrai um possível cromatismo das forças:

\begin{abstract}
Diríamos que o "princípio da participação" nem sempre se deixa conter pelo "princípio do corte". Com efeito, em muitos casos, a propagação das forças é o que põe as formas em "variação contínua", permitindo que se passe de umas para as outras por dentro de suas próprias diferenças (Barbosa, 2014, p. 19).
\end{abstract}

Voltando aos casos etnográficos, se pudermos recuperar essa última noção de participação, não mais entendida como um efeito da classificação, tal qual supunha Bastide, mas como uma relação primeira em relação à classificação. Esse deslocamento metodológico evidencia mais o aspecto relacional do parentesco a partir das concepções de heranças espirituais e o que seriam seus conteúdos do que uma estrutura formal de transmissão de direitos e deveres. Nesse sentido, a sucessão dos terreiros, como o caso do Sítio do Pai Adão, envolve todo esse fluxo relacional das coisas que são herdadas, e menos aspectos sociológicos de transmissão, linhagens cujos conteúdos (tangíveis ou intangíveis) estariam garantidos. Uma similaridade de fundo que caracterizaria as relações de parentesco ao se moverem por aproximações e convergências entre partes, proporções e frações que comporiam as pessoas, consequência da diferenciação das pessoas em relação aos distintos relacionamentos entre santos, pessoas e entidades.

Um exemplo dessa distinção apriorística é a ideia de que o conflito irrompe no Sítio quando essas classes teriam criado um ponto de indistinção com suas respectivas prescrições de parentesco. Mas, como vimos, essa indiscernibilidade é, antes, constitutiva do universo do candomblé nagô. Em um regime onde o que seria da ordem do "dado" é a relacionalidade generalizada (que é, note-se, um dos modos de se entender o conceito de axé), as heranças espirituais são uma condição, a princípio, comum a todos os praticantes do candomblé. Esse ponto tem ressonância direta com a noção de enredo apresentada por Clara Flaksman a respeito do candomblé baiano:

Muitas vezes, meus amigos de Salvador se referiam ao tipo de relação que pode acabar levando alguém a fazer o santo como enredo. "Fulano tem enredo", diz-se de alguém que tem uma relação que, em última instância, quase sempre diz respeito aos laços familiares que, por sua vez, também podem ser múltiplos e diversos, envolvendo humanos, orixás e outras entidades. Ter enredo, portanto, significa ter uma relação familiar, ancestral - seja direta ou indireta - com algum orixá; e seria então pela vontade deste que se estaria ali naquele momento. Tomemos como exemplo o caso de Leila, neta de sangue de Mãe Carmem, portanto, bisneta de Mãe Menininha. Leila leva consigo, como herança familiar, a Oxum de sua bisavó. Não somente isso: além 
de Oxum, ela tem, na sua cabeça, Ewá - a mesma que, ao que tudo indica, também pertencia à Mãe Menininha. Os orixás individuais de Mãe Menininha, neste caso, passaram diretamente para Leila, sua bisneta, que os recebeu como herança. A linhagem de sangue e de santo se tornou, assim, uma só, e não duas superpostas, como indicou Costa Lima. Como entender, portanto, a transmissão por herança? O que exatamente é transmitido? No Gantois verifica-se uma preocupação constante com a reconstrução desses laços de parentesco, marcada principalmente pela busca de uma linhagem que seja concomitante, tanto de santo quanto de sangue (Flaksman, 2014, p.132).

A isso, eu adicionaria uma questão: como as pessoas devem criar contrições e singularizações à essa relacionalidade generalizada? Ou, como diria Pai Paulo, como "ganhar do oculto"? Conforme mostrei no decorrer dessa tese, o santo e o sangue operam cortes um nos outros, interna e externamente. É dizer, todo mundo tem enredo, mas alguns são mais fortes e participam mais da vida das pessoas a depender do corte que essas relações propiciam e ao modo como eles se individuam em uma pessoa, uma família ou uma casa de santo.

Desse modo, nem todos os descendentes consanguíneos de Pai Adão possuem uma relação íntima com o candomblé; nem todos os pais e mães de santo descendentes de Pai Adão podem herdar o Sítio; nem todas as pessoas conseguem cultuar jurema e candomblé na mesma intensidade; poucos são os que conseguem reverter a perda de um conhecimento ritual contando apenas com sua intuição. Essas singularizações são uma expressão de força, tanto da que atravessa a pessoa anteriormente (ter uma ascendência forte, ter uma divindade forte), quanto da capacidade de manejar essa força, extraindo dela o melhor rendimento possível. "Ganhar do oculto" é, afinal, a “confirmação".

Entretanto, não podemos tomar essas relações como resultado de qualquer segmentação normativa, do tipo de relações de transmissão preferenciais por uma das linhas cognáticas, algo que poderia ser lido como uma patrilinearidade ou matrilinearidade. A noção de heranças espirituais contrasta com formulações mais usuais sobre o parentesco no candomblé, que toma as pessoas, coisas e seres como diferentes de início. Restaria à agência humana, portanto, agrupá-las, categorizá-las ou classificá-las; em suma, relacioná-las.

A exemplo do que propõe Bastide (1958, p. 337), tais agrupamentos atendem a um “enquadramento prévio", que, a partir de forças de repulsão e atração, estabelece "as participações místicas [que] se operam dentro dos diferentes compartimentos real”. Esses compartimentos são, nas palavras de Bastide, "estanques" e formados por "correntes metafísicas" das quais participam objetos e seres, que, como coloca o autor, passam a participar 
dessas classes seguindo uma "direção" "orientada" pelo que chama de religião, "o conjunto de representações coletivas ou dos ritos que designam as linhas de forças dentro das quais ela pode se processar".

Entende-se, a partir disso, que certos elementos se constituem enquanto classes a partir de suas naturezas distintas e guiadas por sistemas lógicos anteriores. Por exemplo, no caso nagô, as classes dos eguns, dos orixás e dos espíritos da jurema. E que no interior de cada uma dessas classes são adicionados novos elementos e referências que participam de seu conjunto. Não obstante, Bastide enfatiza que essas adições são guiadas por forças de repulsão e atração, ou seja, que as participações possuem graus diferentes.

Nesse sentido, se revertermos o modelo de Bastide em relação à classificação e à participação, no qual o autor enfatiza que a criação das classes se daria em uma direção, ou seja, na adição em uma coluna expandida verticalmente. Meu ponto é que a criação das classes pode se dar em outras direções também. Há mais. Isso implicaria que, no lugar de pensar que as participações se dão exclusivamente no interior das classes, elas próprias produzem novas classes. Por exemplo, eguns e orixás podem ser vistos como classes separadas, mítica e ritualmente. A manipulação ritual de cada um desses domínios possui regras estritas de separação e intervalos temporais e espaciais de um domínio para o outro. Contudo, quando uma pessoa no nagô invoca um orixá, além da fórmula ritual de invocação, os eguns principais de uma casa - em especial aqueles que foram filhos de santo do orixá em questão — são chamados para que aproximem mais o orixá da pessoa e vice-versa.

Isso insere uma nova classe de participação que, em lugar de se encaixar nas classes verticais, cria uma outra classe que atravessa as anteriores, tornando impossível pensar as distinções das classes anteriores da mesma forma - ou seja, as próprias classes que antes existiam, transformam-se. É dizer: a invocação de um orixá só é uma invocação na medida em que chama também esses eguns específicos. Outro exemplo disso ocorre quando uma pessoa recebe um orixá de herança. Como vimos, um dos modos de confirmação de um orixá de herança é o reconhecimento de certas características. Isso pressupõe que as idiossincrasias do antigo filho de santo passam a integrar as características do orixá geral — novamente se faz um novo corte nessas classes. Em suma, as participações se dão em várias direções, não apenas verticalmente e no interior de uma classe estanque, de modo que aquilo nomeado por Bastide 
enquanto classe é um momento dos movimentos de repulsões e atrações que caracterizam as linhas de força.

No decorrer deste capítulo, procurei explicitar como esse modo de relação/reversão de diferentes modalidades de culto em um mesmo terreiro podem operar de maneira análoga às suas concepções de parentesco. Talvez o que denomino como parentesco de sangue e de santo, no lugar de modelos complementares ou divergentes, deva ser visto em termos de "transformações potenciais" um do outro. Desse modo, heranças espirituais, mais do que meios de comunicação ou sistemas de classificação, seriam fenômenos da experiência que guiam e estabelecem modos de interação com o mundo a partir de certas disposições do universo conceitual que as precipitam. Essas diferentes modalidades servem como um contexto implícito de uma para outra e se desdobram sobre diferentes realidades: herança dos assentamentos, casas, santos, técnicas divinatórias, dons e até mesmo sobre o sangue e as heranças espirituais de meus anfitriões. 


\section{CONSIDERAÇÕES FINAIS}

\section{A NOSTALGIA COMO FORÇA}

“É possível dizer que o xangô é um mundo que vive no passado", constatou José Jorge de Carvalho (1987, p. 38), em um artigo intitulado "A força da nostalgia: a concepção do tempo histórico dos cultos afro-brasileiros tradicionais", publicado poucos anos depois do falecimento de Malaquias, Vicência, Lídia Alves, Manoel Mariano, Amara e toda uma geração de grandes pais e mães de santo das grandes casas de candomblé do Recife. Tratou-se do fim de uma era, a exemplo de momentos anteriores, como o retorno de grande parte dos fundadores africanos para a Nigéria no início do século, culminando com a morte de Adão no final dos anos 30.

A atmosfera vivenciada por José Jorge naquele período, e que acredito ter motivado o conteúdo do artigo, foi experimentado por mim no início de minha pesquisa de campo do doutorado, com a morte de Pai Paulo e outros de sua geração, como sua irmã, Tia Zite, e, por último, mas não menos importante, na queda do Iroko do Sítio de Pai Adão, todos em um intervalo tão breve de tempo. O desafio de escrever diante desse momento de luto coletivo foi uma das minhas grandes dificuldades na construção da tese. $\mathrm{O}$ artigo de José Jorge evidencia uma forma com a qual os praticantes do nagô estabelecem novos horizontes frente a contextos e situações dramáticas. Serviu, portanto, como motivação para lidar com a escrita desse tipo de evento.

Carvalho discute a noção do tempo histórico e mítico no xangô recifense. Mostra a oscilação e a tensão entre o orgulho expresso por um passado glorioso, domínio dos grandes antepassados africanos e sua sabedoria e conhecimento, e uma carência do então momento presente do culto:

\footnotetext{
A música que ora se ouve não é mais tão bem cantada; os tambores, um pálido reflexo da maneira antiga de tocar; a dança, também uma imitação sofrível dos maravilhosos toques de antes; uma iniciação completa de hoje já não tem o axé (força espiritual e mágica) de uma simples conta lavada por um famoso pai-de-santo do princípio do século (Carvalho, 1987, p. 39).
}

O autor observa três processos que respondem a esse sentimento de perda: a ênfase na glória antiga, o sentimento de crise pela perda da memória coletiva e os movimentos de 
transformação na busca da continuidade do próprio modelo de culto. $\mathrm{O}$ que caracteriza esses processos é justamente uma "atitude nostálgica" dos integrantes do xangô.

Essa atitude nostálgica identificada por José Jorge impulsionou interações e empréstimos entre o nagô e outras nações de seu tempo, especialmente a xambá - em particular, o ritual de iniciação, tido como dispensável para Adão. Essas trocas propiciaram o crescimento do nagô sob a égide de José Romão e Malaquias, ao assumirem as funções rituais nas grandes casas xambá, com a morte de Arthur Rosendo, quando quase todas passaram a adotar rituais nagô. Após anos de repressão e morte de sua primeira geração, o nagô estava circunscrito a duas casas, nas quais certos rituais ficaram até vinte anos sem serem executados, alguns cânticos sequer eram entoados, práticas rituais desapareceram e não se realizavam festas públicas. Com a projeção inspirada por José Romão e Malaquias, o nagô tornou aos seus dias de glória, com grande vitalidade.

No entanto, essa vitalidade decai com a morte de quem a incorporou, Malaquias e os últimos de sua geração. Diante disso, Carvalho (1987, p. 39) diagnostica que no nagô "sente-se em tudo a insuficiência do presente e uma luta desesperada por reter, ou pelo menos registrar, a rica experiência humana passada". Conforme mostra o autor, a nostalgia tem como horizonte ideal a África enquanto uma expressão geográfica que condensa em si o tempo mítico, ou melhor, a completa africanidade do culto nagô, sempre presente nos distintos momentos do culto e seus intervalos: seu momento anterior à escravidão (século XVI), com o intervalo das chegadas oriundas do tráfico até 1880, e depois a história de consolidação e apogeu do xangô, sucedido pela morte de uma geração em 1980, e as práticas de transformação descritas.

Tais práticas de transformação são "dinâmicas constantes de revitalização" por parte de pais e mães de santo que, na época, realizavam trocas e viagens para outras cidades e estados, como Salvador e Rio de Janeiro. Esse momento que marcou a entrada do jeje no Recife pelas mãos de Raminho de Oxóssi. Todos esses atos foram "pequenos passos na direção dessa África completa", de modo que, "qualquer movimentação geográfica, mesmo ao encontro do que é novo, tem sabor de regressão temporal, ao já conhecido" (Carvalho, 1987, p. 57). É nesse sentido que Jose Jorge projeta que a próxima busca de revitalização do nagô passaria, necessariamente, em um futuro retorno à África: “o xangô formula finalmente uma concepção de movimento temporal que acaba projetando o encontro, no futuro, com o mesmo passado de onde surgiu" (idem). O modelo cronológico de José Jorge de Carvalho realizou-se como uma "profecia". 
Em agosto de 2013, uma comitiva do Ilê Iemanjá Ogunté foi para Nigéria participar do colóquio internacional "Afro-identidades nas encruzilhadas: o gênio criativo africano e afrodiaspóricos além da globalização e do século XXI", organizado pela Faculdade de Letras da Obafemi Awolowo University. Essa viagem foi um convite feito ao Maracatu Raízes de Pai Adão, para que tocasse no evento. Além de conhecer a cidade de Ilê Ifé, o Maracatu e, por efeito, a família foram ainda para Oshogbo, Oyo e Lagos. Essa viagem foi marcada por muitos encontros ou, como me disse Mãe Lu, "reencontros".

Como descrevi em minha dissertação, Pai Paulo fez um relato emocionado de um dos seus principais momentos na viagem, que foi seu encontro com o Alafin de Oyo ${ }^{113}$ :

"Eu cantei para a mãe de Xangô. Então o Rei se levantou e me abraçou de igual para igual, como se fosse de um rei para outro rei. Nesse momento eu fui tomado pela emoção, já não era mais eu, era meu pai Malaquias, meu avô Adão, meu bisavô. Eu não consigo nem dizer. Ele nos reconheceu, reconheceu que a gente era de lá da África. Ele disse que nosso iorubá era arcaico, que não teria hoje na África seis pessoas que soubessem do nome da Mãe de Xangô, e eu sabia, ele disse que precisou vir alguém do outro lado do Atlântico e cantar para mãe de Xangô, como eu cantei. Nosso iorubá é arcaico mesmo, como falou o rei de Oyo. Vem das heranças de meu bisavô Alapinni. Estava de volta lá, como meu Avô fez. Então o Rei de Ifé pediu para que eu me ajoelhasse e aquela coisa toda, então me deu o título de Baba Ifamuyiide, que significa 'Ifá trouxe esse filho de volta para casa' e deu o título de Yeye Ifamuyiide para Lucinha, que significa 'Mãe que Ifá trouxe de volta para casa'. É como diz aquela cantiga de Ossãe, que os filhos de Ilê Ifé vão retornar para casa. Aí me levaram para ver Ogum lá em Ilê Ifé, cheguei lá e cantei para Ogum. Fui cantando e ia puxando a letra assim, alongando, e eles olhando. Cantei como meu Pai cantava."

O momento de maior importância em sua viagem à África não ocorreu apenas pelo fato de ele estar lá, mas por ter sido reconhecido no lugar de onde, o pai narrava, vinha sua família. E foi por meio do "cantar como meu pai cantava" que o rei o abraçou. Nesse momento, se relembrarmos o que disse Pai Paulo, ele já não era mais "ele", Pai Paulo era seu Pai, seu avô e seu bisavô. Assim o pai se fez presente, cantando. Por meio desse cantar que foi decisivo na forma de experienciar o solo africano, o conceito de África é também experimentado

${ }^{113}$ Ogbeni Adesoji Aregbesola, o Aláàfin (Rei de Oyo). 
analogamente ao modo especial de se relacionar com os orixás, ou eguns, ou seja, por meio das cantigas e invocações.

Mãe Lú também experimentou uma espécie de reencontro na paisagem africana. Ela nos conta que chegou às margens do rio Os $u n$, em Oshogbo, um dia após os festejos em louvor a Oxum. O rio Os $\underline{\text { un }}$ fica em meio a uma reserva florestal de mais de 70 hectares, na cidade de Oshogbo, na Nigéria.

"Foi muita emoção conhecer as terras de nossos ancestrais. Chegando lá, parecia que eu sempre morei ali, eu não estranhei nada, eu andava no carro e as crianças na rua me chamando de 'mommy', 'mommy', tinha que ver. Nós fomos para Ifé, Oyo e Lagos. Mas eu gostei mesmo de Oshogbo, cidade de Oxum, eu sempre fui muito apegada com Oxum, desde novinha. Nós chegamos no templo de Oxum, em Oshogbo, um dia depois do festival. Aquela floresta enorme, mata fechada mesmo, cheia de esculturas milenares dos orixás. E fomos até o rio Oxum, que rio lindo, a água é dourada, não é barrenta não, e bem profundo. Dava pra ver nas margens as oferendas que tinham colocado no dia anterior. Então eu fui lavar minha cabeça nas águas de Oxum, e os meninos pedindo para eu lavar a cabeça deles no rio também, são meus sobrinhos, mas eu também sou a mãe de santo e madrinha de quase todos eles. Quando eu estava na margem do rio, me abaixando para pegar água com a mão, eu vi um braço bem preto, cheio de jóias pegar na minha mão, foi muito rápido, meu sobrinho, marido de Jaciane, filha de Cicinho, estava atrás de mim e me puxou, foi muito forte mesmo a irradiação do santo, quase que eu me 'encantei' e entrei no rio para sempre, foi Oxum. Eu consegui ver ainda o dorso do peixe no meio do rio, um peixe enorme dourado, da cor de ouro velho, quando meu sobrinho me pegou."

Barbara, filha de Mãe Lú, que nos acompanhava no momento da conversa, disse que o peixe só apareceria para os descendentes de Oxum e que seu tio, Paulo, havia lembrado que Mãe Lu vivenciara um "mito de Verger". Curioso, pergunto para ela que mito era esse, ela, então, vai para a sala de sua casa, abre uma gaveta e retira uma antiga edição do livro "Orixás", de Pierre Verger (ano). O livro de capa dura continha alguns desenhos de seu neto Thalysson — ela sorri e fala que ele adora escrever nos livros também. Então, Mãe Lu procura entre os capítulos aquele que fala sobre o orixá Oxum e lê em voz alta o trecho que narra o encontro do Rei de Oshogbo com o peixe nas margens do rio. Segundo Barbara, Mãe Lu repetira os atos do primeiro Rei de Oshogbo: "Mainha fez sem saber o que o primeiro rei fez, ele não se abaixou 
e pegou água com as mãos? Era o que mainha fez sem saber, e o rei apareceu para ela”. Mãe Lu, consente com a cabeça, seus olhos se enchem de lágrimas e ela diz emocionada: "foi mesmo, foi assim que aconteceu comigo também, Oxum e o peixe se mostraram para mim, devo ser descendente dela, nós devemos ter ancestrais em Oshogbo também”.

Do ponto de vista das pessoas da família, sua ligação com a África parece depender das noções herança e descendência. A viagem para África foi convencionalizada de acordo com seus próprios termos, ou seja, foi um retorno tal qual previsto por José Jorge. Apresentou-se também para eles como uma confirmação, a partir da produção de parentesco (memória afetiva, modo de cantar, reconhecimento de feições e traços físicos), da incidência da força dos ancestrais e orixás (encontro com Oxum, título de Ifá).

Como vimos, Pai Paulo enfatizou que seu iorubá, e seu modo de adoração, é diferente, do tempo dos antepassados, inclusive de antepassados africanos. Pode-se dizer que o próprio iorubá é percebido como uma reversão temporal que afeta tanto brasileiros quanto nigerianos; “eles já não falam o iorubá arcaico”, “eles já não sabem o nome da mãe de Xangô”, quando essa diferença é expressa de maneira ambígua; ou como uma superação das dificuldades, "alcancei coisas que meu tio e meu pai não puderam". Isso não impediu que os viajantes reconhecessem certas "coincidências".

Ao longo da tese, procurei descrever os diferentes modos que as pessoas do nagô compõem suas famílias e suas casas de santo a partir da relação entre as linhas do santo e do sangue, vetores que ora aparecem de maneira mais próxima uma da outra, ora mais distanciada. Essa relação é, portanto, como um movimento, cujo caráter dinâmico evidencia uma espécie de tensão constante que impulsiona a si própria por meio da atividade ritual. Nesse sentido, a distinção construída pela literatura sobre o tema, a saber, entre uma noção de família ou núcleo familiar lato sensu e a família de santo como uma forma de organização derivada dessa primeira não faz sentido. Como vimos, a família de santo não serve enquanto substituta do núcleo familiar consanguíneo, enquanto uma resposta à desestruturação social e histórica das famílias negras no Brasil.

É possível afirmar, ao menos para os casos do candomblé do Recife, que as famílias de santo são indissociáveis das famílias consanguíneas, ou seja, em um plano elas não se distinguem enquanto formas organizacionais familiares. Com efeito, nesse caso, é como se a 
família de santo motivasse a própria existência da família consanguínea, ou que o sangue só emerge como um termo marcado no interior das relações de santo. Em outro plano, essas duas dimensões - o santo e o sangue - se segmentam. Quer dizer, o movimento não é estático, e a família de sangue, por sua vez, reconfigura também a família de santo. Nesse sentido, a própria noção de consanguinidade é transformada, ou revertida, em novos termos que pressupõem, necessariamente, a participação do universo de referência das divindades e demais seres espirituais.

Devemos nos reter neste ponto. Ao passo que o sangue é um vetor importante na transmissão do santo, ele atua também como um limite, na medida em que cada pessoa se configura de maneira muito específica nessa relação. A linha do santo, por sua vez, opera um limite na linha do sangue, já que nem tudo aquilo que é espiritual será transmitido igualmente e de maneira homogênea para todo e qualquer um que participe de uma família consanguínea.

Essa discussão deve levar em conta o modo como as pessoas do candomblé, organizados em famílias de santo, dispõem suas relações, e pensam e elaboram seus relacionamentos rituais. De partida, os dois casos, "o sangue" e "o santo", do contraste aventado acima, só faz sentido a partir e por meio de sua natureza ritual. Seus vínculos e a diferenciação que elicitam tornamse mais evidentes a partir dos complexos procedimentos envoltos na iniciação.

A iniciação, conforme descrito no primeiro capítulo, é o ato ritual que marca a feitura de uma pessoa no santo, que implica na introdução dessa pessoa na família de santo, ou seja, de certo modo, cristaliza em uma nova disposição a relação entre a pessoa e seu orixá, sua filiação em uma casa, e principalmente sua introdução em uma rede de parentesco espiritual, passando a ter mãe, pai, padrinhos, madrinhas, irmãos e antepassados. Lembremos que a interdição fundamental da iniciação é aquela que proíbe uma mãe ou pai carnais iniciarem seus próprios filhos. Tal ato distancia as linhas do sangue e do santo, evitando que elas se tornem excessivamente próximas ou mesmo indiscerníveis. Uma questão advinda daí é: como uma família consanguínea, na qual as mesmas pessoas sejam simultaneamente parentes de santo e de sangue, se constitui como família de santo? A feitura reconfigura essa rede de relacionamentos ao dispor um novo enquadramento, de modo que as pessoas passam a interagir não mais do ponto de vista "apenas" das relações consanguíneas, mas também, e principalmente, adicionam a esse conjunto de atitudes os tratamentos relativos às relações de senioridade (e, portanto, hierárquicas) do santo.

Mas, ao mesmo tempo que traz uma aparente "nova" configuração, a iniciação, de certo modo, confirma algo que o recém-iniciado já tinha. Ou seja, como vimos, a iniciação é 
entendida como um complemento ou uma confirmação de uma série de disposições místicas e existenciais próprias de cada pessoa, ou da família de que ela faz parte. Isso aponta, ao menos para o nagô, que a iniciação não é determinante no engajamento das pessoas com o culto, mas uma consequência possível de sua relação anterior.

No segundo capítulo, vimos que no complexo ritual da iniciação, são realizadas as obrigações aos antepassados, os eguns. Desse modo, é produzido um segmento em sua linha ascendente consanguínea ao serem incorporados os ancestrais espirituais. Do ponto de vista do iniciante, tanto seus ancestrais consanguíneos quanto os espirituais se transformam em um só todos os espíritos estão trabalhando e atuando por ele. No caso dos ascendentes consanguíneos diretos, a inserção nessa genealogia produz uma reversão da interdição da separação entre linhas de sangue e de santo na feitura do santo. Isso porque, uma pessoa que tenha seus ascendentes consanguíneos diretos falecidos, deverá obrigatoriamente cultuá-los, inclusive com prevalência em relação aos antepassados espirituais. Caso os ascendentes também fossem do santo, como é comum na rede de terreiros que pesquisei, esses serão cultuados como antepassados espirituais de todos os integrantes da casa - diferentemente do caso contrário, ou seja, quando os ascendentes não eram do santo, serão cultuados exclusivamente pelo descendente. Dito de outro modo, nas gerações subsequentes a diferenciação entre ancestrais de sangue e rituais é eclipsada, a diferença entre os eguns é de grau e não de tipo.

A filiação entre uma pessoa e seu orixá, e sua participação na rede de uma família, pode ser traduzida pelo conceito de herança. A herança pode se atualizar em diferentes momentos e contextos, como, por exemplo, em aspectos tangíveis e intangíveis, como a herança de assentamentos e demais objetos rituais, das casas de santo e seus filhos de santo, como também o reconhecimento de determinados traços físicos ou raciais, ou ainda algumas tendências comportamentais e personalidade. Mas, conforme procurei explicitar, a herança não é algo determinante e exclusiva, sendo sempre lida enquanto uma confirmação.

Ou seja, as heranças dos santos evidenciam um conjunto de práticas, elementos e aspectos que se relacionariam a determinadas condições, ou mais especificamente, que se realizariam através do "legado de sangue" - caso específico dos descendentes carnais ou consanguíneos - e por meio da "participação ritual" - para o caso dos filhos de santo a partir da transmissão dos conhecimentos rituais. Esses dois modos, frequentemente justapostos, são confundidos e, às vezes, contradizem-se. Ou seja, não são bem definidos e carregam uma ambiguidade potencial, tratando-se mais de duas tendências explicativas, e menos de distinções bem marcadas. 
Fica evidente a tensão constitutiva da composição entre o santo e o sangue. Procurei mostrar diferentes situações em que ela se apresenta de forma mais explícita, quando essas heranças adquirem contornos dramáticos porque estão relacionadas às obrigações, conforme mostrei nos casos dos cuidados de santos herdados; e mesmo na inevitável convivência de domínios religiosos distintos e por vezes agonísticos, como no caso da Jurema e do candomblé. Em todos esses casos, às imposições e compromissos herdados, a pessoa procura equacionar seus próprios desejos e vontades.

É por meio da descendência, pelas linhas que perpassam as pessoas, através do sangue, que se garante que as pessoas de uma família recebam de seus antepassados seus dons espirituais, suas capacidades de cuidar dos orixás e a responsabilidades que essas heranças implicam. Dessa perspectiva, tais dons são percebidos como vias de transmissão de um conjunto de características, técnicas rituais e conhecimentos dados pelo fluxo familiar. Nesse sentido, é compreender como as heranças não são bens definidas neles mesmos e acessíveis a todos que compartilham de ascendentes comuns. Não se trata de uma prevalência de regras patri ou matrilineares que corresponderiam ao acesso automático de direitos e deveres.

No decorrer da tese, procurei trazer exemplos de contextos e dimensões do candomblé nagô nas quais operam a parte do santo e a parte do sangue. No lugar da criação de uma totalidade que seria reflexo da junção entre família de santo e família de sangue, mostrei como ambas participam uma da outra, de modos muito distintos a depender de cada casa, família e pessoa. Assim, o sangue não garante a todos de uma mesma família um mesmo grau de participação na vida do candomblé, e mesmo dentro do candomblé, os graus de domínio de técnicas e conhecimentos variam entre cada pessoa. A essa variação, e possibilidade de efetivação desse fluxo inicial de possibilidades, deve-se estabelecer uma singularização. A presentificação dessas pessoas se dá nas diversas e recorrentes histórias contadas sobre seus feitos, no culto destinado aos seus espíritos, a permanência de seus assentamentos e objetos rituais sob os cuidados de herdeiros, no reconhecimento de traços raciais, donde a negritude surge como valor específico dos descendentes de Adão. É o caso dos grandes criadores, pessoas famosas e lembradas por suas idiossincrasias que trouxeram força para o nagô; aquele que melhor cantava, uma certa forma de invocar, os melhores tocadores, os orixás mais belos, o domínio ritual de partes específicas do culto. Esses, nas palavras de Pai Paulo, são os que conseguem "ganhar do oculto". 


\section{BIBLIOGRAFIA}

ANJOS, José Carlos

2006. No território da linha cruzada: a cosmopolítica afro-brasileira. Universidade Federal do Rio Grande do Sul-UFRGS.

ANJOS, José Carlos e ORO, Ari Pedro

2009. Festa de Nossa Senhora dos Navegantes em Porto Alegre. Sincretismo entre Maria e Iemanjá. Porto Alegre : Editora da Cidade.

BARBOSA NETO, Edgar Rodrigues

2012. A máquina do mundo: variações sobre o politeísmo em coletivos afrobrasileiros.

Tese de Doutorado em Antropologia Social. Rio de Janeiro: Universidade Federal do Rio de Janeiro.

BASTIDE, Roger

1973. "Contribuição ao estudo do sincretismo católico-fetichista." Sociologia do folclore brasileiro: 106-133.

1973b. Le principe d"eindividuation: contribution à une philosophie africaine ${ }^{\text {ee }}$. In La notion de personne en Afrique Noire. Paris: Éditions CNRS, pp. 33-43.

1983. Estudos afro-brasileiros. São Paulo: Perspectiva.

2001 (1958). O candomblé da Bahia: rito nagô. São Paulo: Companhia das Letras.

BASTIDE, Roger e VERGER, Pierre

2003 [1953]. Contribuição ao estudo da adivinhação em Salvador (Bahia) ${ }^{\text {ee }}$. In Carlos Eugênio Marcondes de Moura (org.). Olóòrisà: escritos sobre a religião dos orixás. São Paulo: Ágora, pp. 57-85.

BINON-COSSARD, Giselle.

1981. A filha de santo. Ollorisá; escritos sobre a religião dos orixás. São Paulo: Ágora, p. $127-51,1981$.

BOYER, Véronique

1996. Le don et l'initiation: de l'eimpact de la littérature sur les cultes de possession au Brésile $^{\text {ee }}$

BRAGA, Júlio Santana

1992. Ancestralidade afro-brasileira: O culto de babá egum. Salvador: CEAO/

Ianamá. s/d. entrevista ao Correio da Bahia.

BRUMANA, Fernando e MARTÍNEZ, Elda

2007. Reflexos negros em olhos brancos: a academia na africanização. Afro-Ásia, 36 (2007), 153-197. 
CARVALHO, José Jorge

1984. Ritual and music of the sango cults of Recife, Brazil (Doctoral dissertation, Queen's University,).

1987. A força da nostalgia: a concepção de tempo histórico dos cultos afrobrasileiros tradicionais ${ }^{\text {ce. }}$. Religião e Sociedade, 14, (2), pp. 36-61.

1993. Cantos sagrados do xangô do Recife. Fundação Cultural Palmares.

2003."AÇÕES AFIRMATIVAS COMO RESPOSTA AO RACISMO ACADÊMICO."

Teoria \& Pesquisa: Revista de Ciência Política 1.42.

CASTILLO, Lisa Earl e PARÉS, Luis Nicolau

2007. Marcelina da Silva e seu mundo: novos dados para uma historiografia do candomblé ketue . Afro-Ásia, 36, pp. 111-151.

CRUZ, Robson Rogério.

1995. Carrego de egum-Contribuição aos estudos do rito mortuário no candomblé. 109

f. Dissertação (Mestrado em Antropologia Social)-Programa de Pós-Graduação em Antropologia Social, Museu Nacional da Universidade Federal do Rio de Janeiro, Rio de Janeiro.

DANTAS, Beatriz Gois

[1982]1988. Vovó nagô e papai branco. Usos e abusos da África no Brasil. Rio de Janeiro: Graal.

1990. Parentesco de sangre e herencia de los santos. Montalbán, n. 22, p. 137.

DO CARMO BRANDÃO, Maria; MOTTA, Roberto.

2002. Adão e Badia: carisma e tradição no xangô de Pernambuco. Caminhos da alma: memória afro-brasileira, v. 1, p. 48, 2002.

FERNANDES, Albino Gonçalves.

1937. Xangôs do Nordeste: investigações sobre os cultos negro-fetichistas do Recife. Civilização Brasileira.

FILHO, Olavo de Souza Pinto.

2015. Cadernos nagô. A antropologia reversa do Alapini Paulo Braz Ifamuide. 2015. Dissertação (Mestrado em Antropologia Social). Programa de Pós-Graduação em Antropologia Social, Universidade de São Paulo. São Paulo.

2017. O coincidir dos santos: imagens e reversões no candomblé nagô do Recife. R@U, 9 (2), jul./dez. 2017: 135-151.

FRAZIER, Edward Franklin.

1942. The Negro family in Bahia, Brazil. American Sociological Review, Washington: American Sociological Association, v. 7, n. 4, p. 465-478, Aug. 1942. 
1943. Rejoinder. In: HERSKOVITS, Melville. J. The Negro in Bahia, Brazil: a problem in method. American Sociological Review, Washington: American Sociological Association, v. 8, n. 4, p. 394-404, Aug. 1943.

FREYRE, Gilberto.

1977 (1933). Casa-grande e senzala. 9 ed. Rio de Janeiro: José Olympio.

GELL, Alfred

1998. Art and Agency: An Anthropological Theory. New York: Oxford University

Press.

GOLDMAN, Marcio

2005. Formas do saber e modos do ser: observações sobre multiplicidade e ontologia no

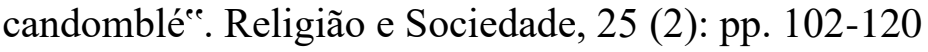

2006. Como funciona a democracia: uma teoria etnográfica da política. Rio de Janeiro: 7 Letras.

2009. Histórias, devires e fetiches das religiões afro-brasileiras: ensaio de simetrização antropológica ${ }^{e e}$. Análise Social, v. XLIV, n. 190, pp. 105-137.

2011. O fim da antropologia ${ }^{e e}$. Novos Estudos CEBRAP, v. 89, pp. 195-211.

2012a."Cavalo dos deuses: Roger Bastide e as transformações das religiões de matriz africana no Brasil." Revista de Antropologia 54.1.

2012b.O dom e a iniciação revisitados: o dado e o feito em religiões de matriz africana no brasil. Mana, v. 18, n. 2, p. 269-288.

2016. Cosmopolíticas, Etno-Ontologías y Otras Epistemologías. Cuadernos de Antropología Social, v. 44, p. 27-35.

GUATTARI, Félix.

1992. Caosmose: um novo paradigma estético. São Paulo: Editora 34.

HALLOY, Arnaud

2005. Dans $1^{\text {ee } i n t i m i t e ́ ~ d e s ~ o r i x a ́ s . ~ C o r p s, ~ r i t u e l ~ e t ~ a p p r e n t i s s a g e ~ r e l i g i e u x ~ d a n s ~ u n e ~}$ famille-de-saint de Recife, Brésil. Thèse de Doctorat, ULB-Bruxelles / EHESS-Paris.

2010a. Chez nous, le sang règne! Terrain, n. 2, p. 40-53.

2010b."La consultation par Ifa à Recife: La (re)naissance de une tradition ? Cahiers du Brésil Contemporain 75/76 : 57-89.

HERSKOVITS, Melville J.

1943. The Negro in Bahia, Brazil: a problem in method. American Sociological Review, Washington: American Sociological Association, v. 8, n. 4, p. 394-404, Aug. 
1943a. The southernmost outposts of New World africanisms. American Anthropologist, Arlington: American Anthropological Association, v. 45, n. 4, p. $495-$ 510, Oct.-Dec.

1956. "The Social Organization of the Afrobrazilian Candomble". Phylon, 17 (2).

Atlanta: Clark Atlanta University, pp. 147-166.

LIMA, Pedro Henrique de Oliveira Germano de.

2016. Constituição da pessoa ogã no Xangô/Candomblé do Recife (o modelo nagô do Ilê Obá Aganjú Okoloyá. Dissertação de Mestrado. Universidade Federal de Pernambuco.

LIMA, Vivaldo da

1977 [2003]. A Família de Santo nos Candomblés Jeje-Nagôs da Bahia: um estudo de relações intragrupais. Salvador: Corrupio.

LINS, Anilson

2004. Xangô de Pernambuco: a substância dos Orixás segundo os ensinamentos contidos no manual do Sítio de Pai Adão. Vol. 4. Pallas Editora.

MARCELIN, Louis Herns.

1996.A invenção da família Afro-Americana: família, parentesco e domesticidade entre os negros do recôncavo da Bahia, Brasil.1996. 325 f. Tese (Doutorado em Antropologia Social) - Museu Nacional,Universidade Federal do Rio de Janeiro, Rio de Janeiro, 1996. 1999.A linguagem da casa entre os negros no recôncavo baiano. Mana: Revista de Estudos em Antropologia Social. Rio de Janeiro, v. 5,n. 2, p. 31-60, 1999.

MARQUES, Lucas.

2016. Caminhos e feituras: seguindo ferramentas de santo em um candomblé da Bahia. Dissertação de Mestrado em Antropologia Social. Rio de Janeiro: Museu Nacional/UFRJ.

MATORY, James Lorand

1999. Jeje: repensando nações e transnacionalismo “. Mana, 5 (1), pp. 57-80.

2005. Black atlantic religion: tradition, transnationalism, and matriarchy in the AfroBrazilian Candomblé. Princeton: Princeton University Press.

MOL, Annemarie

2008. Política ontológica: algumas ideias e várias perguntas. Objectos impuros: Experiências em estudos sociais da ciência. Ed. Afrontamento. 
MOTTA, Roberto

1988. Meat and feast: the xango religion of Recife, Brazil. Diss. Columbia University. 2003. Le Sacrifice Ifá à Recife. Social compass, v. 50, n. 2, p. 229-246.

NUNES, Eduardo Soares.

2012. No asfalto não se pesca: parentesco, mistura e transformação entre os Karajá de Buridina (Aruanã-GO). Dissertação de mestrado.PPGAS-DAN.UnB

OPIPARI, Carmen

2010. O candomblé, imagens em movimento: São Paulo, Brasil. Editora da Universidade de São Paulo.

OYĚWÙMÍ, Oyèrónkẹ́.

1997. The invention of women: Making an African sense of western gender discourses. U of Minnesota Press

2000.Family bonds/conceptual binds: African notes on feminist epistemologies. Signs: Journal of Women in culture and Society, v. 25, n. 4, p. 1093-1098.

PARÉS, Luis Nicolau

2006. A formação do candomblé: história e ritual da nação jeje na Bahia. Campinas: Editora da UNICAMP.

PEREIRA, Zuleica Dantas.

1994.O Terreiro Obá Ogunté: parentesco, sucessão e poder. Dissertação de Mestrado. Universidade Federal de Pernambuco.

PEIXOTO, Fernanda Arêas

2000. Diálogos brasileiros: uma análise da obra de Roger Bastide. São Paulo: EDUSP.

RABELO, Miriam

2014.Enredos, Feituras e Modos de Cuidado: dimensões da vida e da convivência no candomblé. 1. ed. Salvador: EDUFBA, v. 1. 294p .

REIS, João José

2003. Rebelião escrava no Brasil: A História do Levante dos Malês em 1835. São

Paulo: Companhia das Letras. 
2008. Domingos Sodré, um sacerdote africano: escravidão, liberdade e candomblé na Bahia do século XIX. São Paulo: Companhia das Letras.

\section{RIBEIRO, René.}

1978 (1952). Cultos afro-brasileiros do Recife. Recife: Instituto Joaquim Nabuco.

1982 (1955). Antropologia da religião e outros ensaios. Recife: Massangana.

ROSA, Laila Andresa Cavalcante.

2009. As juremeiras da nação Xambá (Olinda, PE): músicas, performances, representações de feminino e relações de gênero na jurema sagrada.

ROSALDO, Michelle Z.

1980. "O uso e o abuso da antropologia: reflexões sobre o feminismo e o entendimento intercultural". (Publicado originalmente em Signs: Joumal of Women in Culture and Society. Spring 1980. Vol. 5. n.3: 389-417. Tradução de Cláudia Fonseca. Maria Noemi Castilhos Brito e Rafael Rossoto loris.).

RUBIN, Gayle.

1975.The traffic in women: Notes on the" political economy" of sex.

SANSI-ROCA, Roger

2009. " Fazer o santo": dom, iniciação e historicidade nas religiões afro-brasileiras. Análise Social, (190), 139-160.

SANTOS, Juana Elbein dos 2002[1972]. Os Nàgô e a morte: pàde, àsèsè e o culto Égun na Bahia. Petrópolis: Vozes.

SARDUY, Aída Esther Bueno.

2014. El ocaso del liderazgo sacerdotal femenino en el Xangô de Recife: la ciudad de las mujeres que no será. Tese de Doutorado. Universidad Complutense de Madrid.

SCHNEIDER, David. M.

1965.Some muddles in the models: or, how the system really works. The relevance of models for social anthropology, n. 1, p. 25-85, 1965.

1984.A critique of the study of kinship. Ann Arbor: The University of Michigan Press, 1984.

SCOTT, Michael W 2007. The severed snake: Matrilineages, making place, and a Melanesian Christianity in Southeast Solomon Islands. Carolina Academic Press. 


\section{SEGATO, Rita Laura}

1984. A folk theory of personality types: Gods and their symbolic representation by members of the Sango cult in Recife, Brazil. 1984. Tese de Doutorado. Queen's University.

2004. Inventando a natureza: família, sexo, gênero no xangô do Recifee ${ }^{e}$. In: Carlos Eugênio Marcondes de Moura (org.). Candomblé: religião do corpo e da alma - tipos psicológicos nas religiões afro-brasileiras. Rio de Janeiro: Pallas, pp. 45-102.

2005[1995]. Santos e daimones. O politeísmo afro-brasileiro e a tradição arquetipal. Brasília: EdUnB.

SERRA, Ordep J. Trindade 1995. Águas do Rei. Petrópolis: Vozes

SILVA, Vagner Gonçalves da

1995. Orixás da metrópole. Petrópolis: Vozes.

2000.O antropólogo e sua magia. São Paulo: Edusp.

2020. “Exu - Um Deus Afro-Atlântico no Brasil”. No prelo.

SILVERSTEIN, Leni.

1979.Mãe de todo mundo: modos de sobrevivência nas comunidades de Candomblé da Bahia. Religião e Sociedade. Rio de Janeiro. n. 4,p. 143-170.

SOGBOSSI, Hippolyte Brice

2004. Contribuição ao estudo da cosmologia e do ritual entre os Jêje no Brasil: Bahia e Maranhão. Tese de Doutorado em Antropologia Social. Rio de Janeiro: Universidade Federal do Rio de Janeiro.

STRATHERN, Marilyn.

2012. O gênero da dádiva: problemas com as mulheres e problemas com a sociedade na Melanésia. Campinas: Editora da UNICAMP

2015. Parentesco, direito e o inesperado: parentes são sempre uma surpresa. São Paulo: Editora Unesp, 2015.

VALENTE, Waldemar.

1955. Sincretismo religioso afro-brasileiro. Brasiliana, 1955.

\section{VERGER, Pierre}

1953. Contribuição ao estudo da advinhação em Salvador ${ }^{\text {ee }}$ Revista do Museu Paulista, 7, pp. 357-380. 1981. 
[1994]2002. Orixás: deuses iorubás na África e no Novo Mundo. São Paulo: Corrupio.

VERGER, Pierre e BASTIDE, Roger

2002. Dimensões de uma amizade. Rio de Janeiro: Bertrand

WAFER, James William.

1991. The taste of blood: spirit possession in Brazilian Candomblé. University of Pennsylvania Press.

WAGNER, Roy

[1975] 2010. A invenção das Culturas. São Paulo: Cosac Naify, 2010

[1977]2019.Analogic Kinship: a Daribi example. American Ethnologist, Vol. 4, N. 4 . pp. 623-642. 


\section{GLOSSÁRIO}

Acaça / Akasa: bolo de massa de farinha de milho, amarela ou branca, cozida em água.

Adjuntó ou juntó: segundo orixá de uma pessoa.

Agbe: instrumento musical utilizado em todas as cerimonias do nagô, composto por uma cabaça envolta em uma trama de fios de algodão com contas de plástico, toca-se batendo no fundo da cabaça.

Alguidar. Vasilha de argila usado em oferendas e assentamos dos orixás.

Agogô: instrumento musical, duas ou uma campânula de ferro, percutida por um bastão, faz a marcação da célula rítmica que acompanha os cânticos.

Ala: grande pano branco, por vezes de renda, utilizado na saída dos iaôs.

Amassi: banho de folhas frescas maceradas.

Arroz de Orixala/ Egbo: Arroz branco, cozido sem temperos, colocado em um prato branco na forma de um bolo e coberto com mel. Cerimônia semanal, recebendo o nome de Ossé, quando são entoados os canticos de Orixala, as pessoas pegam os pratos com a comida votiva, ajoelham-se e colocam sobre sua cabeça, fazendo pedidos.

Assadaka: bebida composta de acaçá batido com mel em agua.

Assentamento: composição de objetos rituais que constituem a dimensão material do orixá de uma pessoa, geralmente constituído por potes de barro, vasilhas de porcelana, seixos de rio, búzios e moedas. Cada divindade possui uma composição especifica de objetos que compõe seu assentamento, por exemplo: Ogum, vasilha de barro com inúmeras ferramentos e artefatos de ferro, Orixalá, vasilha de porcelana branca, pedras, colares e cascas de caramujos. 
Ataquete: uma faixa branca de pano, utilizada durante o obori, composta por uma parte posterior proeminente, em formal oval, pode ser bordada com búzios, quando se trata de uma pessoa iniciada há muitos anos.

Até: esteira de palha utilizada no obori e nas obrigações anuais das quais a pessoa fique recolhida. No obori o até desdobra-se num grande lençol branco colado na parede contigua ao chão em que essa esteira foi colocada.

Ayaba: ou yaba, termo que designa mulheres que cuidam das pessoas em transe, equivalente as ekedis nos candomblés de outras regiôes do Brasil.

Axêxê: rito fúnebre dos nagô do Recife.

Axó: roupa em yoruba, as peles dos animais abatidos após serem retiradas são denominadas como axós.

Axogum: homem responsável por realizar os cortes dos animais nas oferendas, aquele que tem "mão de faca". Em Recife quase todos os babalorixás desempenharam a função de axoguns em sua trajetória espiritual.

Babalaô: pai do segredo, aquele que manipula o oráculo por Ifá, composto por ikins e opelê e opom.

Babalorixá: pai de santo.

Balé: "quarto dos mortos", território dos eguns, ou espiritios dos antigos iniciados do nagô.

Barracão: sala principal do terreiro, onde são realizadas cerimônias públicas.

Batá: tambor dedicado ao culto dos eguns. Sua execução rítmica é batendo em suas duas extremidades, ambas cobertas com pele. Sua afinação é similar a das alfaias de maracatus, na disposição de seu encordoamento. Outra especificidade é a presença de guizos em torno de suas extremidades. Seu uso é restrito ao universo dos eguns em especial das cerimonias fúnebres. Poucas casas possuem o trio de tambores bata. Recife é o dos poucos lugares da diáspora africana há preserva a tradição do uso desses tambores de origem nigeriana.

Beguiri: é uma comida de Ifá feita com quiabos e carne cozidos com bastante pimenta, camarões secos, uma das principais oferendas a este orixá, acompanha uma sequência de cânticos no momento da entrega desse prato até ao assentamento do orixá.

Búzios: conchas de moluscos marinhos, amplamente utilizado nos terreiros como meio de consulta as divindades, a partir de um método divinatório conhecido como Jogo de Búzios.

Casa de santo: Termo mais utilizado no Recife para referir-se aos terreiros de candomblé.

Catimbó: sinônimo de jurema ou de feitiço 
Comida seca: conjunto de oferendas para os orixás das quais não há uso do sangue de animais ofertados nas obrigações. Contudo, partes de animais, como coração, pulmão, fígado, não sacrificados, mas comprados em açougues, também adquirem o estatuto de comida seca.

Confirmação: Técnica divinatória empregada no nagô para verificar as mensagens de divindades e seres espirituais sobre o resultado das obrigações. A confirmação de um jogo ou recado é uma etapa importante no diálogo com Ifá. Além do jogo com dezesseis búzios, existe em Recife um método com oito búzios, que é utilizado após as obrigações, para saber se as divindades acolheram as oferendas e qual o recado preliminar para a pessoa. Variam de acordo com as técnicas rituais empregadas. As caídas de confirmação que são consideradas positivas são: Obijoko, Edimeji (sim “absoluto") e Alafia. No caso de Obijoko e Alafia, deve-se seguir a confirmação de outra jogada para saber se eles "falam de bem" ou se "falam de mal", se a jogada seguinte for Edimeji, então se entende que foi confirmado "pelo bem", mas se cair qualquer uma das outras caídas, então, o resultado é negativo e cabe ao jogador descobrir o recado.

Deká: uma das obrigações do ciclo das cerimonias iniciaticas, considerado como fim do ciclo de iniciação de uma pessoa, na qual ela atige a "maioridade" após sete anos da primeira obrigação de iniciação. Após essa cerimonia a pessoa pode abrir uma casa de culto e iniciar outras pessoas.

Dijina: nome iniciático, termo de origem kimbundu.

Dobale: forma de saudação praticada por iniciados cujo orixá é masculino. Na família sagrada estudada, esse termo tende a substituir o termo "ika", que indica a forma de saudação dos iniciados cujo orixá é feminino.

Ebó: este termo designa a cerimônia de "saida do ebó", que geralmente ocorre três dias após a obrigação e durante a qual as ofertas são retiradas do terreiro e depositadas em local apropriado, mata, rio ou mar.

Ebo dinan: oferenda para Orixalá com vistas a cura de doenças. Consiste em 1 alguidar médio 1 colher de madeira, 1 metro de tecido (morim) branco; 4 cebolas grandes...

Ebomi: do iorubá égbon mi, meu irmão mais velho, pessoa que cumpriu seu ciclo iniciático. Há uma flexão de gênero nessa palavra em Recife, se for um homem é chamado como ebomi, se for mulher ebami.

Efun: nome dado à argila branca com a qual o corpo do noviço é pintado durante o processo de iniciação.

Egun: nome dado aos espíritos dos mortos. 
Ekedi: Mulheres que não entram em transe no candomblé.

Ialorixá: sinônimo de mãe do santo, iniciador.

Iaô: iniciado tendo iniciado completamente e ainda não tendo completado seu deká.

Igbá: geralmente denota o consentimento feminino, composto por pratos de cerâmica.

Ifá: um sistema oracular de origem africana, que é baseado no manejo de dezesseis nozes de dendê ou búzios, para obter uma combinação entre um conjunto de 256 signos gráficos denominados odus. Ifá, dizem os Babalaôs ("pais dos segredos"), é o jogo "da fa" por onde fala Orumila. Segundo ouvi de um importante sacerdote de Ifá: "Ifá significa palavra forte na boca de Orumilá. Ifá explica tudo, não existe nada no mundo e na vida que não tenha explicação em Ifá”. Para alguns em Recife, Ifá e Orumilá são o mesmo ser, não sendo possível diferenciá-los. Outros afirmam que Ifá é o jogo criado por Orumilá e, portanto, Orumilá não seria exatamente a personificação de Ifá, mas seu inventor. Segundo Pai Paulo, Ifá seria Odifá, "por onde fala Orumilá”.

Ika: pequeno bolo em formato esférico ao qual se adcionam pedaçõs das comidas secas do obori.

Ikin: Caroço de dendê com "quatro olhos" ou furos, simbolo de Ifá.

Ilu: tambores rituais do nagô, são em geral 3 tambores, com pele das duas extremidades, o menor é chamado de melê, o do meio, melê ankó, e o maior o Iyan, inhã. melê: nome dado ao tambor agudo no xangô. Também conhecido como tambor de "marcação", desde que não varie e mantenha o ritmo básico.

melê-ankó: nome dado ao tambor intermediário no xangô.

Ixã: vara ritual do culto dos eguns, pode ser confeccionada com galhos de akoko ou de amora. Iyerosun: pó amarelado usado para a consulta do oráculo por Ifá.

Jogo de Búzios: Em Recife, conforme descrito anteriormente na tese, é, geralmente, consultado na modalidade de 16 búzios, conhecida por Erindilogum (Halloy,2005: Carvalho, 1984). São consiedradas as caídas das combinações entre os búzios abertos e fechados:

1 fechado / 15 abertos: Obewane

Fala Exú

2 fechado / aberto 14: Obijoko

Fala Orixalá

3 fechado / 13 abertos: Axe Ogunda

Fala Ogun / 
4 fechados / 12 abertos: Obi Obara

Fala Xangô / Iemanjá

5 fechados /11 abertos: Obixé

Fala Oxum

6 fechados / 10 abertos: Obiorossum

Fala Oyá

7 fechados / 9 abertos: Obidi

Fala Xangô/ Iemanjá

8 fechados / aberto 8: Ejonilê

Fala Orixa Oguian.

9 fechados / 7 abertos: Osatinukó

Fala Iemanjá

10 fechados / 6 abertos: Obeofum

Fala Orixalá

11 fechados/ 5 aberto: Wanesobe

Fala Exu

12 fechados / 4 abertos: Ejilaxebora

Fala Xangô

13 fechados / 3 abertos Ogunda Massa

Fala Obaluaiê / Nanã / Exu

14 fechados /2 abertos: Joko EjilaObixé

Fala Ibeji

15 fechados / 1 aberto Otobirikusa

Fala Obaluaiê Xaponã / Naná / eguns

16 fechados: Ijobe Baba Male

Fala: Orunmila / Exu / Nanã / Omolú

16 abertos Okangarasa

Fala Orunmila

Os escritos contêm também uma maneira de relacionar seus conteúdos em relação à sua apresentação: 1) número de búzios abertos e fechados; 2) Orixás que falam nessa caída; 3) recado do jogo; 4) ebó recomendado.

Outro método de jogo de buzios é o com oito búzios, que é utilizado após as obrigações, para saber se as divindades acolheram as oferendas e qual o recado preliminar para a pessoa: 
1 aberto: Etawa

Negativo, espiritos de esquerda, atrapalhações, falta algo.

2 abertos: Obijoko

Positivo, paciencia para alcançar os objetivos.

3 abertos: Ogunda

Pode ser negativo, precisa jogar para ver o recado.

4 abertos: Edimeji

Confirmação positiva.

5 abertos: Okaran iku

Negativo.

6 abertos: Oyeku

Negativo.

7 abertos: Wane

Negativo,

8 abertos: Alafia

Positivo, mas precisa confirmar com Obijoko ou Edimeji.

obe: faca utuilizadas nas atividades rituais.

oberé: ou curas, são as incisões iniciáticos, padronizadas de acordó com as nações dos candomblés.

obi: noz de cola.

oborí: uma das principais cerimônias iniciáticas no nagô.

obrigação: Termo associado aos rituais iniciáticos, ou renovações destes, em especial as cerimônias que envolvem a oferenda de animais.

odu: configuração obtida por uma ou outra técnica oracular: búzios, opelé, ikins. Cada odu está associado a um ou mais orixás que fala por meio dos "recados". Cada odu é único e seria um tipo de registro onde se encontrariam todas as informações que explicam os acontecimentos da vida de uma pessoa. No Brasil, é comum ouvir as pessoas ligadas ao candomblé se referirem aos odus como destinos ou caminhos que as pessoas devem percorrer, quando estão sob seu domínio. Nesse sentido, o próprio Ifá poderia ser entendido como uma antologia de acontecimentos. 
opon ifá: uma pequena bandeja redonda de madeira, geralmente decorada, sobre a qual são jogados búzios ao consultar o oráculo com os búzios, ou sobre os quais se espalha o iyerosun para consulta por Ifá.

opele: rosário composto por 8 metades de nozes usadas na consulta de Ifá.

osun: pó vermelho de origem africana usado por certos líderes de culto para pintar o corpo do noviço durante a iniciação.

recado: os recados dos odus, orixás ou entidades, prescrevem e fornecem uma importante via de acesso para os diversos rituais do nagô, como as obrigações de Ifá, eguns e diversas oferendas para orixás. Esse manejo de relações em outros domínios rituais permite também uma passagem a outros universos conceituais, como, por exemplo, o da jurema. Pai Paulo afirma que Obirossum, por exemplo, é um odu que traz um recado da jurema. Quando essa caída saía no jogo de seu avô, ele "despachava" a pessoa para um terreiro de jurema, pois ele não trabalhava com os mestres e mestras

toada: canticos para os orixás e eguns, outras entindades espirituais, em especial aquelas relacionadas ou universo da jurema, são denominadas de linhas.

waji: pó azul de origem africana usado por certos líderes de culto para pintar o corpo do noviço durante a iniciação.

xirê: termo que se refere à ordem pré-estabelecida para a sucessão de toadas destinadas aos orixás durante o toque. 